\title{
Internal Security
}

\section{and Military Pouver}

Counterinsurgency and Civic Action

in Latin America

Willard F. Barber and C. Neale Ronning

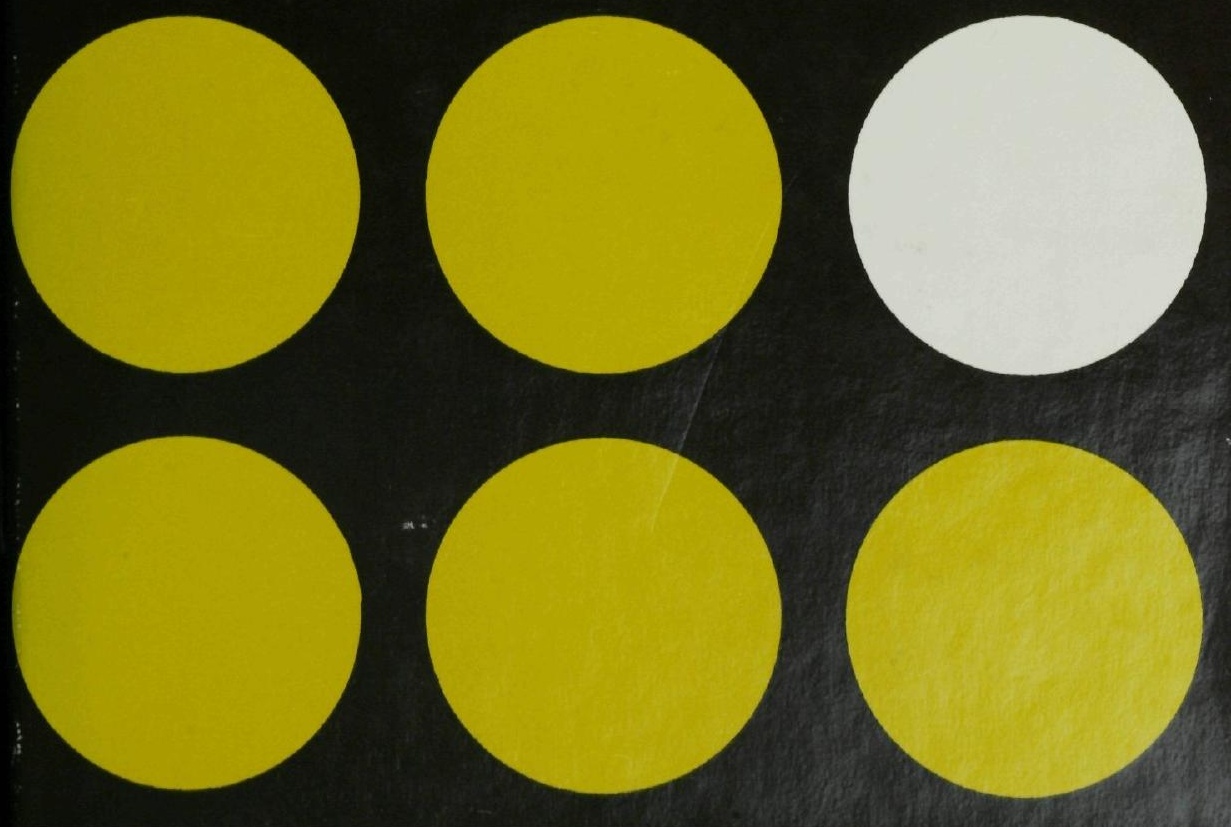


". . . The new generation of miltrary leaders has shown an increasing awareness that armies cannot only defend their countries-they can . . . help to build them." — President John F. Kennedy, March 13, 1961.

By the early 1960's, it had become clear, from the obvious threat posed by Castro's Cuba, that the cold war had entered the Western Hemisphere. The possibility that constitutional democracies would be established in the nations comprising the rest of Latin America had become increasingly remote as the armed forces of Argentina, Bolivia, Brazil, the Dominican Republic, Ecuador, El Salvador, Honduras, and Peru moved successfully to unseat, alter, or block altogether the civilian regimes of their respective countries.

In the hope of averting other revolutions and in the face of further Communist infiltration of the hemisphere, the United States government has pledged its economic policies to the principles of social reform in Latin America. It provided at the same time, the military assistance necessary for the strengthening of internal security forces as a means of achieving the political stability required to effect social reform and bring about economic progress in the face of rapid demographical, social, economic, and even ideological change.

In adopting this policy, the United States has posed for itself a serious dilemma; for it finds itself committed to support of the very institutions in Latin America that, in the past, have so frequently been associated with the forces of reaction and dictatorship. Latin American military officers are trained by North Americans in the techniques of combating the guerrilla with no assurance that the skills learned will not be used in the cause of insurrection or that the officer so trained will successfully distinguish between the revolutionary guerrilla and the protestor of social injustice and oppression. 


Internal Security and Military Power 
A Publication of the Mershon Center for Education in National Security 


\section{Internal Security}

\section{and Military Power}

Counterinsurgency and

Civic Action in Latin America

Willard F. Barber, C. Neale Ronning

Ohio State University Press 
Copyright (C) 1966

by the Ohio State University Press

All Rights Reserved

Library of Congress Catalogue Card Number: 66-11608 
To G.D.B. and M.D.B.M. 



\section{Foreword}

WE Might Well consider that United States relations with the other American republics can teach us about the problems encountered by a great power seeking its own brand of international peace and security through the modulated exercise of variegated influence. Within the inter-American system several styles of alliance behavior have been demonstrated; a rudimentary form of collective security has been operated. Meaningful implications for Western, Asian, and Near Eastern commitments are waiting to be drawn. When the United States plunged headlong into a world-wide program of economic and military assistance, years of experience with analogous measures in the Western Hemisphere had developed patterns of co-operation and, what is more important, structures of expectations concerning the results.

How to attain political stability amidst rapid demographic, social, economic, and even ideological change 
is the problem. What the United States can do to help whom in solving this problem is the question. For some time Latin America has been the testing ground. Latin American officers are trained by North Americans in how to combat the guerrilla-the instructors offering up a prayer that their pupils will find the new game more engrossing than the old one of "throw out the president," that they will not use learned techniques to aid the cause of insurrection, and, above all, that they will successfully distinguish the revolutionary guerrilla (badly infected with alien ideology) from the protestor against injustice and oppression (a goodly agrarian reformer).

It is at this point that a kindred United States policy enters, cloaked in the euphonious phrase "civic action," or how to put the military to use and get the deprived to love the uniform. That the policy is important no reader of the news from Vietnam can doubt. However, the Latin American test in the long run may be equally, if not more, significant. For in the Western Hemisphere we are attempting to discover whether a politically influential force in most of the countries can become, not the instrument for direct, United States intrusion, but the means for national self-help. And become so in time, before unrest turns to implanted, externally directed insurgency. If both tests cannot be passed, the United States may, within the next decade or before its Vietnam war is concluded, confront an equally unpleasant dilemma much closer to home.

For a time "civic action" was hailed in official military and civilian circles as a quick-acting panacea. But most of the salutes were set off by those who either knew little about the other American republics or read only each other's reports. The significant contribution of the pres- 
ent study is to cut through the eulogies and self-serving justifications and uncover the complex reality underneath. The reader should expect to find the record difficult to generalize but very far from encouraging. In particular instances some home truths emerge starkly: recipients of largesse are insatiable; they find new ways to dislike their benefactors; the military does not take kindly, enthusiastically, or permanently to (lowly) nonmilitary activities; outside instigators make a shifty target and show a sneaky talent for profiting from programs seeking to eliminate them.

The authors know what they are writing about. Existing, available evidence is painstakingly and objectively analyzed. Each brings impressive credentials to the undertaking. As Foreign Service Officer, Willard Barber served in many Latin American posts and in several State Department posts dealing with Latin American affairs. C. Neale Ronning, a political scientist, has also spent much time in Latin America-including a trip made specifically for purposes of this study-and has delved deeply into the sources and implications of political violence in a number of countries. A continuing focus of research by the Mershon Social Science Program in National Security is the United States position within the Western Hemisphere. Internal Security and Military Power is a central product of that research effort.

Edgar S. Furniss, Jr. 



\section{A clemouledgments}

The authors wish to express their gratitude to the Mershon Center for Education in National Security of the Ohio State University for the opportunity afforded them to undertake this study. The General Research Board of the University of Maryland provided assistance to one of the authors during the summer of 1964, enabling him to initiate preliminary research. Two graduate assistants, Fred Starner and Jack Lewis, aided in this study. Our particular thanks go to the latter for his patient diligence in tracing documentary and bibliographical material. To scores of friends and professional colleagues in public service (both military and civilian) and in private life, we renew our gratitude for their generosity in sharing with us experiences and insights. Any errors are, of course, our own.

W. F. B.

C. N. R. 



\section{Contents}

CHAPTER 1: Introduction

CHAPTER 2: Arena of Decisions:

The Early 1960's

CHAPTER 3: Development of a Doctrine:

Civic Action

CHAPter 4: Administrative and Planning Agencies: A Program without a Bureaucracy

CHAPTER 5: Training

Chapter 6: Civic Action and Counterinsurgency

Chapter 7: Armies for Progress?

\section{Appendixes}

A Illegal and Unscheduled Changes of Heads of State, 1930-1965, by Country (Part I) and by Year (Part II) 
B U.S. National Objectives Relating to Overseas Internal Defense

C Resolution III on Military Co-operation of 1951 Meeting of Foreign Ministers

D Resolution XLVII of the Inter-American Defense Board (1960), on the Contribution of Armed Services to Economic and Social Development

E Resolution II of Punta del Este (1962), the Eighth Meeting of Foreign Ministers, on Subversive International Communism

If Précis of the Counterinsurgency Course (1963), the Special Warfare School, Fort Bragg, North Carolina

G Texts of a Military Assistance Agreement of the Military Mission Agreement, and of Exchanges of Notes on Internal Security

H "Problem Areas": An Excerpt from "Military Civic Action," Prepared by the Department of the Army

I Text of Resolutions Regarding the Dominican Republic (1965), Adopted by the Tenth Meeting of Consultation of Foreign Ministers (Inter-American Peace Force) 299

A Selected Bibliography 


\section{Illustrations}

Figure 1: Composition and Organization of the Special Group for Counterinsurgency

FIGURE 2: Composition and Organization of the Office of the Secretary of Defense

FIGURE 3: Field Administration of Military Assistance

FIGURE 4: United States Department of Defense Organizations for Counterinsurgency and Civic Action 115

Figure 5: United States Department of the Army Organizations for Counterinsurgency and Civic Action 151 



\section{Tables}

TABLE 1: United States Bilateral Military Arrangements

TABLE 2: United States Military Assistance to Latin America

Table 3: Draftees in Latin America, by Number, Age when Drafted, and Length of Service

TABLE 4: Military Expenditures and Force Levels, by Country

TABLE 5: United States Military Aid to Latin America, 1952-61

Table 6: Proposed Program for United States Military Assistance for Civic Action to Latin America for the Fiscal Year 1965

table 7: AID and MAP Civic Action, 1962-64 239 



\section{Abbreciations}

AID

CAMTT

CIAP

DOD

G/PM

IADB

IAGS

IDP

ISA

JCS

MAAG

MAP

MATA

MTT

NIS
Agency for International Development (formerly ICA, ECA, FEA, and so on)

Civil Action Mobile Training Team

International Committee for the Alliance for Progress

Department of Defense

Deputy Assistant Secretary of State for Political/Military Affairs

Inter-American Defense Board Inter-American Geodetic Survey

Internal Defense Plan

Internal Security Affairs, Office of the Department of Defense

Joint Chiefs of Staff

Military Assistance Advisory Group

Military Assistance Program

Military Assistance Training Advisers

Mobile Training Team

National Interdepartmental Seminar on the Problems of Development and Internal Defense 
NSC

OAS

OCB

SEABEES

STAT

USCONARC

USIA

USOM

USSOCOM
National Security Council

Organization of American States

Operations Co-ordination Board

CB (Construction Battalion of Navy Personnel

SEABEE Technical Assistance Team

United States Continental Army Command (Fort Monroe, Virginia)

United States Information Agency

United States Operating Mission, the Office of AID Located in a Foreign Country

United States Southern Command (Quarry Heights, Panama Canal Zone) 
Internal Security and Military Power 



\section{Chapter 1}

\section{Introduction}

In signing the Act of Bogotá in 1960 and the Charter of the Alliance for Progress in 1961, the United States explicitly pledged its economic policies to the principles of social reform in Latin America. But the very condition that prompted the signing of these documents-the threat of social revolution-also counseled the immediate strengthening of security forces within the Latin American countries. Here was a built-in dilemma. Strengthening the security forces within Latin America meant a strengthening of the armed forces-the very institutions that had often been associated with reaction and dictatorship.

The frequency of illegal and unscheduled changes in Latin American chiefs of state during the nineteenth century was often the work of military coups, and in recent times military coups are still the cause of most of the illegal changes. In many cases civilians either supported the coups or were active participants. Questions that could always be asked were: "Which civil- 
ians?" or "How many civilians?" It could also be asked, "Which military?" or "How many military?" For there are often divisions among the military as well as within the larger body politic, exemplified by recent military coups in Argentina, Brazil, and the Dominican Republic. Since 1930, the Western Hemisphere has witnessed, in addition to the assassination of President Kennedy in 1963, 106 illegal and unscheduled changes. The number includes chiefs of state who were assassinated, committed suicide, or were forced from office. It does not include accidental or natural deaths. (The data are given in full in Appendix A.) To list the number of unsuccessful attempts at assassination and coups d'état would add greatly to this dismal statistic. It is Mexico's good fortune and honor to be the only country not on the list. Ecuador and Bolivia are cited eleven and ten times respectively for their political changes during the thirtyfive years.

There appeared to be at least one avenue for the resolution of the dilemma of security and reform: the reorientation of the Latin American armed forces. This meant, on the one hand, a stern policy of disapproval when the armed forces interfered with constitutional processes. ${ }^{1}$ On the other hand, it would mean exposing them in that portion of their professional training that they might receive in the United States, to a democratic atmosphere, including the concept of the supremacy of civilian authority in government. Furthermore, an effort would be made to channel the military's time and energies into economically useful activities.

However one looked at it, the big question in the confrontation of the threat of social revolution in Latin 
America would be the role of the military. The posture and the status of Latin American armed forces and their intervention in politics has been studied for many years by a wide variety of scholars. Recent works have advanced contradictory theses as to the visible trendsthat the military is becoming more professional- and less political-minded, or that there has been a resurgence of political interventions and take-overs on the part of the military leaders.

In this study we shall investigate only one aspect of the role of the military in Latin America: their role in meeting the current threat of insurgency. In reference to this role we shall use the term counterinsurgency, and in analyzing it we shall give particular attention to the concepts and programs of civic action. The variety of meanings attributed to these terms in contemporary literature and in official usage suggests the need to offer the reader some "official definitions"-those used in the Dictionary of United States Military Terms for Joint Usage, issued on February 1, 1964, by the Joint Chiefs of Staff.

In the voluminous military literature scanned by the authors, a veritable multiplicity of explanations, definitions, and illustrations of terms was encountered. In non-military publications, the usages were even more disparate. It is evident that the necessity for obtaining uniformity of nomenclature brought the Joint Chiefs of Staff to the decision to adopt a set of specific terms. Of course this did not mean that the interpretations of the definitions would become uniform and unambiguous. The definitions did not achieve this result among our own military services, much less in the Latin American armed 
forces, and even less in the writings of North and South American civilians.

"Military Civic Action" 2 is defined as "the use of preponderantly indigenous military forces on projects useful to the local populations at all levels in such fields as education, training, public works, agriculture, transportation, communications, health, sanitation, and others contributing to economic and social development, which would also serve to improve the standing of the military forces with the population. (United States forces may at times advise or engage in military civic actions in overseas areas.)" It will be noted that both long range and immediate or intermediate objectives are indicated in this definition: (a) economic and social development, and (b) to improve the standing of the military forces with the local population. This serves to emphasize a point that will become clearer as our discussion proceeds: although in Department of Defense doctrine, civic action is only a part or a technique of counterinsurgency, in practice it is at times treated as a program related to other objectives such as economic development or improved civil-military relations. It is argued, of course, that the latter objectives have effects that are useful in countering subversion and insurgency. (It might be more accurately stated as "prevention of insurgency.")

But economic development, or improving the image of the military, for example, may become ends in themselves. This helps to explain why we speak of counterinsurgency and civic action, although by the official definitions, civic action is encompassed within counterinsurgency. It might be observed, for example, that 
officials of the United States Agency for International Development think of civic action in terms of projects that would contribute to economic development. State Department officers engaged in the same programs might well be thinking in terms of how the project on which they are engaged could divert military influence and activity from political intrigue, and influence the armed forces toward contributions to representative government and constitutional practices. And simultaneously, as has been made clear, the United States military have the purpose of improving the standing of the local military with the population. In the sense that economic development is a form of counterinsurgency (we repeat, it might be more properly phrased as "prevention of insurgency"), the larger part of United States policy in Latin America, including the Alliance for Progress, could be said to have this objective insofar as that policy is concerned with political stability and hemispheric security. An attempt to synthesize these different objectives may be seen in the statement of $U$. S. National Objectives Relating to Overseas Internal Defense, reproduced in Appendix B. This only emphasizes that the concept of counterinsurgency is in many minds as loose and confusing as that of "military civic action."

"Subversion" is defined as "action designed to undermine the military, economic, psychological, morale, or political strength of a regime." "Insurgency" is defined as "a condition resulting from a revolt or insurrection against a constituted government, which falls short of civil war. In the current context, subversive insurgency' is primarily communist inspired, ${ }^{3}$ supported, or exploited." "Counterinsurgency" is defined as "those 
military, paramilitary, political, economic, psychological, and civic actions taken by a government to defeat the subversive insurgency."

In reports, testimony before congressional committees, and in unofficial books and articles, civilian and military officials do not always adhere strictly to these definitions. Counterinsurgency may be used with reference to actual combat with insurgent groups as well as to action intended to prevent an outbreak of insurgency. These activities, then, may range over a wide spectrum. They could include the actual use of force, a show of force, or improving the popular image of the military and the police in order to maintain order. Counterinsurgency may even encompass the reform or the mitigation of distressing social and economic conditions. To most readers the term probably connotes actual combat with rebel or guerrilla bands. We emphasize, therefore, that in official circles, as well as in the present study, the term has a much broader implication.

The authors are aware of the difficulty and danger of using the term "Latin American" when referring to policies or conditions. They have, between them, studied, traveled, or lived in all of the American republics. One has only to mention a few examples to bring the divergencies and variations among them into sharp focus: Brazil compared with El Salvador; isthmian Panama compared with land-locked Bolivia; or Haiti contrasted to Chile. The importance of these differences will be emphasized in our discussion of the Latin American civicaction programs, their administration and application.

The omission of Cuba from our study was viewed as necessary rather than desirable because of the paucity 
in this country of information about its military and paramilitary organizations and their functions. Discouragement by the United States government of the idea of a possible visit for research in that country brought the authors to the conclusion that Cuba would have to be omitted.

Data are primarily from unpublished materials, in many cases from the personal experiences and private files of persons who have been working with civic action in the field and in Washington. Some of the material representing opinions and judgments was made available on a highly personal basis and will not be identified except in terms of general categories. Correspondence and interviews produced much data and cvaluations based upon personal experience. The main sources of unpublished data were officials in Washington, I'nited States military missions in five Latin American countries, United States Embassy, AID (for an explanation of this and other acronyms see page xvii), officials and members of governments in Latin American countries, United States and local citizens in Latin American countries, and United States military personnel in the Canal Zone and in United States military schools and training centers.

Our discussion begins with a brief survey of conditions and events that appear to have been important so far as United States policy-makers were concerned in the formulation of the doctrines relating to counterinsurgency and military civic action in I.atin America. This will be largely a discussion of why these doctrines emerged. Chapter III discusses more specifically the factors that have shaped the doctrine of civic action and 
some of the reasons why the doctrine emerged in its particular form. Chapters IV and V discuss some of the administrative, co-ordinating, and training agencies that deal with counterinsurgency and civic action. Chapter VI deals with civic action and counterinsurgency although, as we have emphasized, the term counterinsurgency in the Latin American context emphasizes "prevention of insurgency." Chapter VII reviews the problems and the prospects of counterinsurgency and attempts to place in a reasonable perspective the issues pertaining to military civic action.

In estimating the lasting value to be derived from military civic-action programs in their classic manifestations of road-building, school construction, and literacy and medical services offered, it is significant to recall that precisely these activities have for two decades been characteristic of United States policies toward Latin America. Under the rubric of the Good Neighbor Policy and the beginning of the Institute of Inter-American Affairs, dating back to the 1930's, these have been the familiar programs through which technical know-how and financial aid have passed. They are now embodied in the Alliance for Progress. These are the same kinds of activities that the Peace Corps has undertaken. In Peru, the identrcal programs are being taken up by the Popular Co-operation Movement, for which university students devote their holidays. As local voluntary organizations, as well as the whole panoply of United States foreign aid (Food for Peace, Peace Corps, Alliance for Progress, and others) use these names to promote the spirit of community development and economic improvement, the questions daily become more acute: 
Are these the areas in which military civic action should concentrate? Can not the civilian organizations, public and private, national and alien, do the job?

1. President Kennedy's administration did not consistently maintain a stern attitude toward coups; as months went by there was a discernible change. This tendency continued under President Johnson.

2. Throughout this study the word military will usually be dropped from the term "military civic action." This is partly a matter of convenience and partly the result of quoting or paraphrasing documents, speeches, and other sources where the shorter term is used. In all cases, however, references are to military civic action, whether or not the word military precedes the term.

3. The reader will note that in this definition "subversive insurgency" is by definition "primarily communist inspired." 



\section{Chapter 2}

\section{Arena of Decisions: The Early 1960's}

Among the many trends, events or conditions in Latin American countries and in inter-American relations, five appear to have had an important influence on decision-making in the United States in the early 1960's. They were not new, nor were they the only facts of importance in United States policy-making. In some cases they represented an important stage in a long trend; in others, the significance lies in the fact that they were more clearly perceived at that point. In a few cases, the events that were referred to occurred closer to the mid-1960's. They are mentioned because they emphasize or shed light upon the importance of earlier and related events. What is most important for purposes of our discussion is that, together, they produce a climate of urgency, perhaps even desperation in the search for a Latin American policy. Their complexity as well as the dilemmas they presented might also serve as a warning to the reader that the job of the policy analyst and critic is less hazardous than that of the policy-maker. 


\section{Cuba}

By the early 1960's, the cold war had moved unmistakably into the Western Hemisphere. There had indeed been evidence of this throughout much of the preceding decade, but one development more than anything else served as a watershed. In Cuba, Fidel Castro had triumphed in a nationalist revolution and had subsequently set up a Communist government. The warning that "it could happen here" was already out of date. It had happened.

Threats and attempts to spread the Cuban revolution to other parts of Latin America were alternated with official and unofficial attempts to invade Cuba from the United States and Central American countries. The spiral of challenge and response culminated in the missile crisis of October, 1962. But the easing of this crisis left the over-all situation unchanged. Political, economic, and social conditions in most of Latin America made it obvious that the area was ripe for social revolution. The Cuban revolution was evidence of one of the directions that other revolutions might take.

\section{The Inter-American Security System: Frustration and Tension}

Throughout the 1950's the signs of Communist penetration of the Western Hemisphere had not gone unobserved. In response to them the United States made attempts, based on the Rio Treaty, to get inter-American action against the governments of Guatemala and Cuba on grounds that Communist influence or control there was a threat to hemispheric security. 
In 1954 , the Tenth Inter-American Conference ( $\mathrm{Ca}-$ racas) approved a United States sponsored resolution that declared that "the domination or control of the political institutions of any American State by the international communist movement would constitute a threat to the sovereignty and political independence of the American States, endangering the peace of America and would call for a meeting of Consultation." But approval of the resolution had been preceded by bitter debate, outright opposition from some of the more democratic governments, and apathy or reluctance on the part of others.

In August, 1960, a special meeting of the American foreign ministers held at San José, Costa Rica, was able to agree upon only a very mild and oblique resolution on the Cuban problem. Without referring to Cuba, it merely condemned intervention by an extracontinental power in the affairs of the American republics and rejected "attempts of the Sino-Soviet powers to make use of the political, economic or social situation in any American state." Even this resolution created a crisis within the Venezuelan government when the foreign minister refused to sign the resolution and had to be replaced by an alternate. A statement by the Mexican foreign minister that no condemnation of Cuba was intended further emphasized his government's lack of enthusiasm.

Thus, until the conference at Punta del Este in 1962, "action" took the form of ineffectual resolutions that nearly always had less than unanimous support, ranging all the way from reluctant to enthusiastic. If official or governmental response in Latin America was less than 
optimum to United States policy-makers, the response from non-official sources was often disturbing.

Liberal leaders who claimed to be friends of the United States responded with a number of arguments and complaints. One was that the United States was trying to use the OAs as a cloak to cover interventionist policies when its private investors became alarmed at liberal or leftist governments. Both the Guatemalan and the Cuban crises had been preceded by bitter controversies with the United States over expropriation of U. S. investments; and although the United States insisted that the issue was Soviet or Sino-Soviet penetration and not expropriation, many Latin Americans remained unconvinced.

Another argument was that the United States was supporting military dictators. Unfortunately, there were enough cases in which the United States had gone out of its way to demonstrate its approval of some of the worst dictatorships to give this complaint much credit throughout Latin America. United States demonstrations had ranged all the way from Presidential honors to laudatory (if somewhat uninformed) speeches from the floor of Congress. Military and economic assistance, granted without distinction as to the type of government, only helped to support the complaint. It was also possible to show the unwavering support of the United States by Latin American dictators when the United States had a controversial resolution before an interAmerican conference.

Somewhat inconsistently, a few liberal governments (there were not very many in existence) and many more private sources called for hemispheric action 
against existing dictatorships. But the files in foreign offices are long and deep, and it was possible to bring our the same arguments in support of their propositions that the United States used in calling for action against Communist subversion. The arguments and complaints also contained no reference to the fact that in most cases United States relations with dictatorships were carried on for want of an alternative. Indeed, refusal to deal with them or discrimination against them with reference to assistance would have undoubtedly backfired with the usual charges of intervention.

The most persistent argument throughout the 1950's was that the United States was uninterested in the economic and social functions of the inter-American system. Again there was evidence to give this complaint credibility. There were statements from the highest levels of the executive department to the effect that Latin America could and should rely on private investments for its economic development. Needless to say, statements of this type served as proof for the increasing number of the United States critics who argued that the State Department was mainly interested in preserving Latin America as a private domain for United States investors. Assistance to Latin America was usually compared with assistance to Europe under the Marshall Plan to show that the former was clearly getting the short und of the deal. All of this, of course, ignored the question of whether Latin America was in a position to absorb capital to the extent that Europe was and whether massive assistance to Latin American governments could not have been used to show that the United States was supporting the status quo. The Korean War 
also served to emphasize the urgency of the situation in Asia and to further remove Latin America from public and even private concern in the United States. Latin America was to be "blessed" with its own Korea at the end of the decade.

\section{Economic Assistance: Doubts and Increases}

It is impossible, of course, to determine precisely what effect the arguments of the critics of United States policy had upon the policy-makers. But there is at least much circumstantial evidence to indicate that there was a relationship that was more obvious in some cases than in others. One of the more obvious indications of a relationship was the sudden reversal of policy in the last years of the Eisenhower administration. To the cynical or suspicious, there might well have appeared to be some connection between this reversal and our attempts to marshal hemispheric support for action against Fidel Castro.

A few days before the oAs approved a resolution calling for a conference to deal with the alleged Cuban threat, President Eisenhower (in July, 1960) issued his Newport Declaration. Here the President stated that the United States was prepared to participate in a joint search for effective methods through which the Latin American states could continue to accelerate their economic and social progress. About a month later, Undersecretary of State C. Douglas Dillon, on behalf of the President, asked Congress to authorize $\$ 500$ million for the ends stated in the Newport Declaration. This was 
about a week before the conference actually met at San José, Costa Rica.

In 1959, the United States and the Latin American countries had negotiated an agreement establishing the Inter-American Development Bank. The next year, at Bogotá, United States representatives went even further in accepting certain principles that they had previously refused to accept. The Act of Bogotá affirmed that Latin American economic and social development required a massive injection of external financial resources largely in the form of loans on more flexible terms. At the same meeting, the United States agreed to allocate an additional half billion dollars to create a special fund for social development to be administered by the InterAmerican Bank.

Whatever the factors that contributed to the late President Kennedy's announcement of massive United States assistance under the rubric of the Alliance for Progress, the amount of money involved was unprecedented for Latin America. Later, about $\$ 20$ billion was "foreseen" over a period of a decade, the "greater part in public funds."

The notable features of the new economic assistance policy dealt with much more than simply the part of the world and the amount of money involved. What was perhaps more remarkable was that it came at a time when there were growing doubts concerning the basic assumptions about the relationships between poverty and Communist influence. It was easy to point to plenty of places in the world where a decade or more of United States assistance was not having the desired results. In 
addition, it was impossible to find a single example where unquestionable proof could be offered that economic assistance had been responsible for keeping Communists out of power. This, it must be added, was probably because of the nature of the difficulty of showing cause and effect relationships in such cases, rather than to any proved shortcomings of assumptions about economic assistance.

Critics did, however, attack the basic assumptions of the programs, especially the simplistic notion of a direct relationship between poverty and political instability. Lucien Pye, for one, argued that the social and psychological disturbances attending the development process were far more important than economic factors. Indeed, he pointed out economic development is probably a greater cause of social instability than economic deprivation. He chided as moralistic and contrary to the experiences of history the American belief that the solution to such problems lies in broad programs of development and reform. ${ }^{1}$

In a somewhat similar vein, another critic advocated greater emphasis be given in our assistance programs to "social technology," that is, the training of leaders in the political and administrative skills necessary to manage the development task. He saw the lack of such leadership skill as the primary cause of the stagnation and instability in Cuba preceding the Castro revolution." Those criticisms were given an ambivalent reception by the Congress and the press. On the one hand, it was accepted that foreign aid was pouring money down a rat hole unless it was intelligently and honestly applied within the recipient countries to economic development 
and needed social reforms. But, on the other hand, little was done to provide for the kind of political and administrative training needed to assure such handling of the funds. Instead, there grew up around the economic assistance program a sort of despair that reflected itself in increasing resistances to the continuance of the program. In some cases, it led to acceptance of the inevitability of the authoritarian way to development.

There had been little evidence of sympathy for a second criticism of the program's assumptions raised by many Latin American economists, notable among them, Raúl Prebisch. He insisted that although the Latin American countries needed to undertake major reforms in their social and economic structures, it was even more essential that the United States and other developed nations undertake reforms in their trading relationships with the emerging countries. The onus of responsibility for the economic plight of Latin America was shifted, in this argument, from the Latin American states to the exploiter nations of the north, which, it was said, underpaid for basic commodities and overcharged for finished, manufactured goods. This led to a circle of increasing poverty for the commodity-producing nations and ever increasing wealth for industrialized nations. Among other facts, it was pointed out that one Latin American nation's loss of income with the advent of a one-cent per pound decline in the price of coffee outweighed the total of United States economic assistance to all of Latin America for that year.

Some efforts (such as the International Coffee Agreement of 1961) were made at correcting the instability of the world markets for primary commodities. But the 
United States was far from accepting the position that it was to blame for the underdevelopment of Latin American nations.

\section{The Crisis of Civilion Leadership}

Beginning in the mid-1950's there was a growing optimism concerning the future of civilian government in Latin America. The fall of Juan Perón in the autumn of 1955 was followed by the overthrow or retirement of dictators in Peru, Colombia, Venezuela, and Cuba during the next four years. In Bolivia, Costa Rica, and Brazil, constitutional governments that had replaced dictatorships after World War II seemed at least to be holding their own. The growing optimism was reflected in Twilight of the Tyrants by the seasoned New York Times reporter, Tad Szulc. Published in 1959, it predicted that "the long age of dictators in Latin America is finally in its twilight." ${ }^{3}$

It soon appeared, however, that every silver cloud had a dark lining. By the early 1960's, the armed forces had unseated, altered, or prevented civilian regimes trom taking power in Argentina, Brazil, Peru, Ecuador, Honduras, El Salvador, the Dominican Republic, Bolivia, and Guatemala. But it was not this fact that was the most disturbing. The pendulum had swung from military dictatorship to constitutionalism and back again too many times for most observers to be upset by another swing. What was most disturbing was the poor performance of a number of the civilian governments that had been replaced. This was already becoming evident by the first years of the 1960's. 
In Argentina, civilian administrations showed a complete inability to produce a substitute for peronismo. It should be noted, however, that a large part of the problem was the chaotic economic situation left by the Perón administration and that the provisional military governments (1955-58) made little if any progress in implementing economic reforms or development programs. Under the administration of Arturo Frondizi (1958-62), the cost of living continued to rise while labor's share of the national income declined. Graft, inefficiency, and conspicuous consumption among the elite were visible everywhere, while the government asked citizens to tighten their belts under its "austerity" program. The president, nationalistic and leftist-sounding in his campaign, was unable to fulfil most of his promises to the voters. Without popular support for his program to compete with the peronistas, the Frondizi administration decided to join them. In an appeal for electoral support, the peronistas were promised legal participation in future contests. When they showed a disturbing popularity, not surprising in view of the government's performance, the armed forces unseated the civilian government rather than allow elected peronistas to assume their seats in congress and their posts in the provinces.

In Brazil, although the administration of Kubitschek (1956-61) had its problems of inflation and balance of payments, it could show one of the better records so far as economic growth was concerned. Furthermore, the popular president presided over one of the more peaceful Latin American countries without resorting to the use of violence, which more and more governments were 
forced to rely on in the first years of the 1960's. But in Brazil, as elsewhere, most of the problems remained untouched-land reform, growing slums around all of the large cities, illiteracy, and malnutrition. The Congress no less than the military offered adamant resistance to any fundamental social reforms. According to one observer, more money was spent on the military than on all public works combined. ${ }^{4}$

Kubitschek's successor, Janio Quadros, ran into the same problems and shocked the nation by resigning after seven months in office, claiming that "reactionary forces" were preventing his reform measures from being adopted. Military opposition to Vice-President Goulart brought the country to the verge of civil war; but a compromise was worked out, and he assumed the office of president with its powers severely restricted. The United States, never very happy with Goulart, became less and less comfortable after his full powers were restored following a national plebiscite. There had been numerous charges of Communist sympathy against Goulart, and his appeal to the masses raised fears of another Castro. Following his overthrow by the armed forces in April, 1964, President Johnson's telegram of congratulations left no doubt of his relief and approval over the action.

In Colombia (where the military had not intervened from 1957 to the early 1960's), the two major political parties and their leaders could claim little more than an agreement to alternate control of the machinery of government until 1974. Although until recently such an arrangement had been satisfactory to some of the leaders of the two parties, the results have been considerably less than that in terms of producing a program of development and reform. 
From the beginning of the 1950's to the early 1960's, civilian presidents in Ecuador had managed to remain in power by a combination of ad hoc political support and demagogic appeal. They had, at least, been completing their constitutional term of office, but the formula equaled little more than a holding operation. Although a decade of relative peace resulted in some economic gains for the country, the fundamental problems of land tenure, illiteracy, and poverty were about where they had been a quarter of a century or longer ago. Velasco Ibarra, inaugurated September 1, 1960, relied even more on demagogic appeal than on ad hoc political support. From the outset he relied principally on emergency decrees and his paid gangs of chasmas. To appease the left he issued pro-Castro statements, and to appease the right he did not interfere with the status quo. His term ended with a military coup nearly a year later, following several weeks of unrest in the course of which almost a hundred people had been killed or injured.

In Chile, there were already reports that a socialistcommunist coalition had a good chance of winning in the next presidential and congressional elections. In Bolivia, the civilian government seemed to be fighting a losing battle against right wing and left wing opposition. Some journalists and commentators saw Rómulo Betancourt of Venezuela (1959-64) as a Communist in disguise. His refusal to include Communists in his government was only a clever smoke screen so far as these observers were concerned. The example of Fidel Castro emphasized the possibility that Communists might take over a civilian government on the heels of a liberal revolution.

In defense of the governments that we have discussed, it must be said that they faced enormous problems. 
Archaic social systems, land tenure, illiteracy, rising expectations, inflation, loss of foreign trade, rapid urbanization, and a host of other problems, were a nightmare to anyone trying to establish cause and effect relationships. The economy of much of Latin America was in difficulty in the early 1960's. In almost every country, domestic budgets were deep in deficits; and, on the international level, there were problems in the balance of payments. Large, corrupt, and inefficient bureaucracies were a constant drain on government income. At the same time strong remedial measures would have been political suicide for the chief executives.

From 1951 to 1955, Latin America's increase in product per person was 2.1 per cent per annum. From 1956 to 1960 , it had declined to 1.7 per cent per annum. Even more serious, food production (at least with respect to products locally consumed) had actually fallen behind the rate of population growth in many of the countries." Although industrial production was increasing more rapidly than argicultural production, it failed to provide enough jobs for the growing influx of new residents who poured into slums surrounding all of the larger urban centers.

Drastic measures which were required to meet these problems, inevitably ran into the opposition of vested interests. Attempts to marshal mass support against this opposition carried with them the threat of unrest and even violence. In situations such as this, the armed forces usually stepped in to remove the government in power and "restore order."

The crisis in civilian government as seen in the early 1960's may be summarized as follows: Although the problems confronting Latin American governments had 
multiplied, the political institutions with which to meet this challenge had shown little progress in most of the area.

\section{The Image of the Military}

A fourth factor affecting United States policy in the early 1960's was a changed attitude toward the Latin American military. Once widely regarded as a major impediment to the development of democracy in the hemisphere, the military came to be viewed by many in the 1960's as a bright new hope for progress and reform.

Not surprisingly, a leading publicizer of the new look in hemisphere armies was the United States military. Among those North Americans who had worked with the Latin American armed forces, there was wide agreement that the military was rapidly emerging as a willing and able force for social change. Somę even maintained that "in general most of the military are as conscious of the need of reform as any class in the country." 6

The new regard for military virtues was shared by many outside the defense establishment. One State Department official confided his belief that the military had a better grasp of national problems than most civilians and was certainly better prepared to do something about them.

The military image was refurbished by academicians as well. John J. Johnson, in his study The Military and Society in Latin America, called the military's response to changes in civilian government a landmark in their historical development." In a similar vein, Robert Alexander reported that "Only in a few nations is the 
army still acting as a last-ditch defender of the economic and social status quo. In some cases it is even taking the side of revolutionary changes." 8 Even long-standing critics of Latin America's military conceded the need to revise old stereotypes.

There is little question that this new image weighed heavily in the decision to intrust a broader social role to the Latin American military through civic action. Indeed, the light regard that generally was paid the potential pitfalls of the policy would be difficult to explain otherwise. How else could it be proposed in good conscience that the traditional guardians of the feudal status quo devote themselves more energetically to social affairs? Clearly, some evidence of a basic change in the character of the military was necessary to justify placing such a temptation to power in its way.

\section{II}

\section{Invasion from Abroad or Subversion from Within}

By 1960, the efficacy of many panaceas was being questioned; many errors had become obvious but had not themselves suggested alternatives; many hopes had been shattered; and many grim predictions had been fulfilled. The crisis in civilian government no less than the frustrations and tensions in the inter-American security system were but symptoms of basic problems and dilemmas of Latin American society. It all added up to a climate of urgency and, in the United States, a desperate search for a Latin American policy. What is more, it was a presidential election year when issues would be 
aired more widely, if not more intelligently. A presidential election year was also a good time to demand and promise bold new policies.

Along with the search for a Latin American policy came a reappraisal of hemispheric security policy. That reappraisal brought up the question of the rationale behind the United States military assistance program in Latin America. The rationale behind the program had indeed been questioned before, but because of the small amount of assistance given annually (roughly $\$ 35$ million during the 1950's) some rather dubious explanations were usually permitted to go unchallenged. When challenged by an occasionally persistent congressman or senator, it seemed to have no effect on the outcome of the request for appropriations. In the course of reappraisal, the problem that loomed larger and larger was that of the internal security of the Latin American countries. For those who had been called upon to justify a military program that had been in search of an objective for nearly a decade, this must have been good news.

In framing hemispheric security organization no less than in congressional testimony during the initial years of United States military programs in Latin America, the rhetoric had been in terms of defense against a military threat, especially (although not exclusively) from an extracontinental source. There were, of course, always a few individuals who pointed out the greater danger of Communist subversion. In the statutes of inter-American security machinery and in the testimony relating to United States military assistance, some direct or oblique references to subversion were also inserted. Thus Article 6 of the Rio Treaty calls for consultation in the event of extracontinental or intercontinental conflicts short of an 
armed attack or of any other fact or situation that might endanger the peace of the hemisphere. But, as stated in Article 3, if "an armed attack by any state against an American State" (which calls for assistance from all contracting parties) was clearly intended to include subversion, it certainly could have been stated in unequivocal terms. It is probable that the provision was left vague in order to encourage ratification by those who would oppose the inclusion of subversion as well as those who would approve it. In an area of the world where a majority of the governments normally comes to power by means of "an armed attack," it is not unreasonable to think that many of them would shy away from an unequivocal statement.

In testimony relating to the Mutual Security Act of 1951, Assistant Secretary of State Edward Miller listed four primary military objectives in connection with Latin America: (1) To secure sources of strategic materials; (2) to keep open the lines of access to those materials; (3) to have the armed forces of those countries in readiness to keep the strategic areas defensible from small air and submarine attacks from abroad; and (4) to reduce the commitments of our own armed forces for the defense of those areas. ${ }^{9}$ As late as 1959, Section 105 of the Mutual Security Act stated that internal security requirements would not normally be the basis for military assistance to Latin American nations. ${ }^{10}$

But the argument of an armed attack on the hemisphere as a rationale for building up the Latin American armed forces was never entirely convincing. As the danger of an armed attack from outside became less and less likely, the threat of Communist subversion became more and more fixed in the minds of United States 
policy-makers. By the early 1960's, the process' of reversing the original emphasis was well under way. ${ }^{11}$ The conditions discussed in the preceding section, particularly the crisis in civilian government and the frustration and tensions in the inter-American security system, played an important role in this change. The Guatemalan scare of 195 + became a Cuban reality in 1960: books and articles, learned and unlearned, warned of the increasing danger. Communist statements concerning their strategy in the underdeveloped parts of the world, many of them made 20 to 30 years ago, were given the publicity of new discoveries. A brief review of some of the more important statements emanating from the President, the Department of State, congressional leaders (and legislation), and military leaders will help to demonstrate the new emphasis placed upon internal security in United States hemispheric defense policy.

Prior to his inauguration and in the weeks immediately following, President Kennedy had been informed from various sources, and warned about the position of the Communist movement in aggressively supporting or even instigating "liberation wars." In his message to Congress on March 28, requesting the appropriations for the Defense Department, his statements showed the extent of the shift toward a concern over the internal-security problem. "The free world's security," he said, "ćan be endangered not only by a nuclear attack but also by being slowly nibbled away at the periphery, regardless of our strategic power, by forces of subversion, infiltration, intimidation, indirect or non-overt aggression, internal revolution, lunatic blackmail, guerrilla warfare or a series of limited wars." 12

During 1961 and 1962, on a number of occasions in 
press conferences, formal speeches, in messages to Congress, and in other ways, the President referred to Khrushchev's January, 1961, speech on "wars of liberation." Perhaps an outstanding illustration of the President's preoccupation with the speech was given in his television address to the country immediately following his trip to Europe, the first week of June, 1961. The new and young President, an activist by determined choice. had obviously been strongly impressed, indeed rebuffed and chagrined, in his two-day confrontation with Khrushchev in Vienna.

"Mr. Khrushchev and I," the President said, "had a full and frank exchange of views on the major issues that now divide our two countries. I will tell you now that it was a very sober two days." Most of all, Mr. Khrushchev had predicted the triumph of Communism in the new and less developed countries. He told the President of his certainty that the tide there was moving his way, that the revolution of rising peoples would eventually be a Communist revolution, and that the socalled wars of liberation, supported by the Kremlin, would replace the old methods of direct aggression and invasion. "In the 1940's and early fifties," the President pointed out, "the great danger was from Communist armies marching across free borders, which we saw in Korea." Now the great danger was that a small group of disciplined Communists would exploit discontent and seize control of an entire country without Communist troops ever crossing any international frontier. This, he warned, is the Communist plan. ${ }^{13}$

The State Department's A Case History of Communist Penetration: Guatemala, issued in 1957, perhaps 
encouraged the flow of publications that became a flood after Castro came to power. A common feature of State Department publications and statements on hemispheric security was a growing preoccupation with the problem of Communist subversion. In February, 1963, Assistant Secretary of State Martin outlined the steps which the United States was already taking. Our direct attack on the problem of Communist subversion, he said, has already been launched in two directions. One was to isolate Cuba from the hemisphere and discredit the image of the Cuban revolution in the hemisphere. The other was to improve the internal security capabilities of the countries concerned. ${ }^{14}$ A year later, efforts already under way to bring action into line with doctrine were recorded in an informal unclassified memorandum prepared in the State Department and entitled Points in Explanation of U.S. Military Assistance Program for Latin America. The first paragraph stated in matter-of-fact tones that, "this Administration is seeking to orient the military assistance program in Latin America away from the outmoded concept of hemispheric defense toward greater emphasis on meeting the internal subversive threat."

To Congress, the threat loomed as large as anywhere. A congressional joint resolution of October 3, 1962, called for immediate steps "to prevent by whatever means may be necessary, including the use of arms, the MarxistLéninist regime in Cuba from extending by force or the threat of force, its aggressive or subversive activities to any part of the Hemisphere." Months later, the Senate majority whip, Hubert Humphrey, in pleading for both military and economic aid to Latin America, cited "Che" Guevara as declaring that "The Cuban revolution has 
shown that in conditions of imperialist domination such as exist in Latin America, there is no solution but armed struggle." ${ }^{15}$

TABLE 1*

United States Bilateral Military Arrangements

\begin{tabular}{|c|c|c|c|c|}
\hline Country & $\begin{array}{c}\text { Mission } \\
\text { Agreement } \\
\text { (Army, Air, } \\
\text { or Navy }\end{array}$ & $\begin{array}{c}\text { Bilateral } \\
\text { Milititary } \\
\text { Assist- } \\
\text { ance } \\
\text { Agree- } \\
\text { ment }\end{array}$ & $\begin{array}{l}\text { Internal } \\
\text { Security } \\
\text { Notet }\end{array}$ & Other \\
\hline Argentina & $\mathrm{X}$ & $\mathrm{X}$ & & $\begin{array}{l}\text { Navy War } \\
\text { College Adviser }\end{array}$ \\
\hline Bolivia...$\ldots \ldots \ldots$ & $\mathrm{X}$ & & $\mathrm{X}$ & \\
\hline Brazil ........... & $\mathbf{X}$ & $\mathrm{X}$ & $\mathrm{X}$ & JBUSMC $\ddagger$ \\
\hline Chile...$\ldots \ldots \ldots$ & $\mathbf{X}$ & $\mathrm{X}$ & $\mathrm{X}$ & \\
\hline Colombia ........ & $\mathrm{X}$ & $\mathrm{X}$ & $\mathrm{X}$ & \\
\hline Costa Rica ........ & $\mathrm{X}$ & & $\mathrm{X}$ & \\
\hline Dominican Republic & MAAG & $\mathrm{X}$ & & \\
\hline Ecuador .......... & $\mathrm{X}$ & $\mathrm{X}$ & $\mathrm{X}$ & \\
\hline El Salvador ...... & $\mathrm{X}$ & & $\mathbf{X}$ & \\
\hline Guatemala ........ & $\mathbf{X}$ & $\mathrm{X}$ & $\mathbf{X}$ & \\
\hline Haiti $\ldots \ldots \ldots \ldots \ldots$ & & $\mathrm{X}$ & & \\
\hline Honduras....... & $\mathrm{X}$ & $\mathrm{X}$ & $\mathrm{X}$ & \\
\hline Mexico .......... & & & & JMUSMC \\
\hline Nicaragua...... & $\mathbf{X}$ & $\mathrm{X}$ & $\mathrm{X}$ & \\
\hline Panama....... & $\mathrm{X}$ & & & \\
\hline Paraguay...$\ldots \ldots$ & $\mathrm{X}$ & & & $\begin{array}{l}\text { Civic Action } \\
\text { Note }\end{array}$ \\
\hline Peru $\ldots \ldots \ldots \ldots$. & $\mathbf{X}$ & $\mathrm{X}$ & $\mathrm{X}$ & \\
\hline Uruguay .......... & $\mathbf{X}$ & $\mathrm{X}$ & $\mathrm{X}$ & \\
\hline Venezuela $\ldots . .$. & $\mathrm{X}$ & & & \\
\hline
\end{tabular}

- The texts of military assistance agreements and of exchanges of notes regarding the "internal security" use to which the equipment could be put are found in Appendix $G$.

† Notes specified that materials' use was limited to internal security and hemispheric defense and for no other purpose unless with United States consent.

$\neq$ Joint Brazilian-United States Military Commission.

Joint Mexican-United States Military Commission. 
A report issued on April 14, 1965, by the House Subcommittee on Inter-American Affairs of the Committee on Foreign Affairs brought the story up to date with its version of intrigue, secret meetings, machinations, and selection of priority targets, discussed at the Havana meeting of Latin American Communists in December, $1964 .^{16}$

That Khrushchev's statement of policy had been continuously kept fresh in the minds of the United States military high command was shown by United States Air Force Chief of Staff General Curtis LeMay, in an address at St. Louis, Missouri, on October 19, 1963 :

Khrushchev himself gave us a forecast of that threat in his January, 1961 speech to leaders of the Communist Party. He acknowledged, at that time, that general war and limited war on the scale of the Korean conflict involved unacceptable risks. However, he declared the intention of the Communist Bloc to encourage and support what he referred to as national uprisings and wars of liberation. As we all know, he was referring in that case not to wars of liberation, but to subversive campaigns of aggression which are aimed at the overthrow of proWestern governments. ${ }^{17}$

A year later, General Robert J. Wood, director of military assistance, asserted that "the primary purpose of the proposed fiscal year 1965 Military Assistance Program for Latin America is to counter the threat to the entire area by providing equipment and training which will bolster the internal security capabilities of the recipient countries." ${ }^{18}$ The accumulative amounts of military aid to the Latin American countries, as well as 
the proposed fiscal year 1965 allocation is shown in Table 2 below.

TABLE 2* United States Military Assistance to Latin America
(In Thousands of Dollars)

\begin{tabular}{|c|c|c|}
\hline Country & $\begin{array}{l}\text { Total for Fiscal } \\
\text { Years 1950-64 }\end{array}$ & $\begin{array}{l}\text { Proposed Program for } \\
\text { Fiscal Year } 1965\end{array}$ \\
\hline Argentina $\ldots \ldots \ldots \ldots \ldots$ & $\$ 13,564$ & $\$ 1,206$ \\
\hline Bolivia $\ldots \ldots \ldots \ldots \ldots$ & 10,858 & 591 \\
\hline Brazil $\ldots \ldots \ldots \ldots \ldots$ & 186,846 & 2,314 \\
\hline Chile $\ldots \ldots \ldots \ldots \ldots \ldots$ & 74,259 & 1,096 \\
\hline Colombia $\quad . . \ldots \ldots \ldots \ldots$ & 55,325 & 1,124 \\
\hline Costa Rica $\ldots \ldots \ldots \ldots$ & 1,828 & 13 \\
\hline Cuba $\ldots \ldots \ldots \ldots \ldots \ldots$ & 10,575 & $\cdots$ \\
\hline Dominican Republic ...... & 12,098 & $\ldots$ \\
\hline Ecuador $\ldots \ldots \ldots \ldots \ldots$ & 29,567 & 573 \\
\hline El Salvador ............ & 3,828 & 91 \\
\hline Guatemala $\ldots \ldots \ldots \ldots \ldots$ & 8,702 & 238 \\
\hline Haiti $\ldots \ldots \ldots \ldots \ldots \ldots$ & 3,405 & $\cdots$ \\
\hline Honduras $\ldots \ldots \ldots \ldots \ldots$ & 3,596 & $\ldots$ \\
\hline Mexico $\ldots . . . \ldots \ldots \ldots$ & 1,198 & $\ldots$ \\
\hline Nicaragua ............ & 6,603 & $\cdots$ \\
\hline Panama $\ldots \ldots \ldots \ldots \ldots$ & 1,799 & 16 \\
\hline Paraguay $\ldots . \ldots \ldots \ldots$ & 3,579 & 744 \\
\hline Peru $\quad \ldots \ldots \ldots \ldots \ldots \ldots$ & 66,776 & 1,703 \\
\hline Uruguay $\ldots \ldots \ldots \ldots \ldots$ & 32,912 & 11 \\
\hline Venezuela...$\ldots \ldots \ldots$ & 3,685 & 40 \\
\hline
\end{tabular}

- Source: “Foreign Operations Appropriations for 1965. Hearings before \& Subcommittee of the Committee on Appropriations." House of Representatives. 88th Cong., 2d Sess., April 14, Part I, 1964, pp. 412 and 523.

As far as means were concerned, hemispheric defense doctrine was now clearly preceived and clearly stated. But it soon became apparent that the application of these means would create other dilemmas. 


\section{III}

\section{When Soldiers Are Insurgents}

The evolution of hemispheric defense doctrine from one which emphasized security against an outside attack to one that emphasized security against subversion and internal uprising brought with it two dilemmas for United States policy. First, by encouraging local military forces to prepare for counterinsurgency, training them in these skills, and providing them with equipment, the United States is increasing the power of one of the competing political groups in a given Latin American country. But does this in fact contribute to the stability and security of the hemisphere? Second, can the use of military assistance once it has been provided be controlled by the United States?

The answer to the first question depends on the role that the armed forces of Latin American nations will choose to play when confronted by situations of actual insurgency or by situations where events appear to be moving in that direction. At one time or another, they have assumed four distinguishable roles when confronted by situations such as these. They have served as the guarantors of constitutional government, the self-appointed "guardians" of the national interest, the guardians of order and the status quo, and the promoters of reform.

( ) 1 s in Colombia and Venezuela (and only in the last decade) have the armed forces been willing to protect a constitutional government throughout a relatively prolonged period of violence. In both cases, however, a 
rather inconclusive picture is presented. The rural banditry in Colombia was not insurgency in the sense of aiming at the overthrow of the government or creating conditions that might eventually bring this about. As such there was not the danger of a movement that might destroy the military or at least weaken its position in society. ${ }^{19}$ The present increasing urban violence from labor and student groups will be a much better test of the military's role in this respect. In Venezuela, elements of the military have tried to unseat the government a number of times since 1958. Fortunately, the loyal elements of the armed services have thus far triumphed each time an attempted coup d'état or rebellion has occurred.

More likely, the military will serve as the "guardians" of the national interest by replacing a government that is confronted by growing strikes, riots, and terrorism or one that seems to be in danger of being taken over by a resurgence of labor-leftist forces. This was the stated rationale in recent coups in Argentina, Bolivia, Brazil, the Dominican Republic, Ecuador, Guatemala, and Honduras. ${ }^{20}$

These temporary expedients are fraught with contradictions and difficulties. The armed forces quickly discover that the task of government is not an easy one and have usually found it expedient to turn the government back to civilians. The growing power and influence of labor and student groups soon force a military dictatorship to decide whether it will move in the direction of a police state or a system of representative government. More recently there has also been pressure from the United States whose stated policy in Latin America is to promote social reform and economic development through the Alliance for Progress. 
In returning the government to civilian hands, the armed forces will probably impose two conditions: That the new government not threaten the military as a privileged institution and that its program not disrupt the status quo to the extent that resultant tensions produce violence and disorder in the wake of which more radical groups might gain influence. But a growing laborleftist group will probably find such a program unsatisfactory and resort to agitation, strikes, and even violence. In the short run, any program of national development and reform will probably produce insurgent movements as much as a lack of one. Opposition will develop among a conservative oligarchy that opposes the reforms on grounds of individual or group interests, among those who approve of change but want reforms to move faster, and among extremists who have demanded the reforms but want to bring the program to a halt in order to create conditions whereby they can assume power. Thus the cycle is again repeated with intervention by the armed forces.

If the armed forces continue this role it will raise serious problems for those who have been attempting to improve their image. Will the effects of repeated intervention against constitutional governments serve to wipe out the good will built up through propaganda and civic-action projects? We should not be misled by the momentary popular approval that might follow a military coup d'état. Given the nature of Latin American politics, almost any government's popularity declines rapidly when the time comes to transform the promises of campaign oratory into action. Thus there are always a substantial number of people who will greet the overthrow of any government with enthusiasm--not because 
they approve of the new saviors but because they have become disenchanted with the old ones. The new saviors soon encounter all the difficulties of their predecessors, and, without the pretense of a popular mandate, their popularity vanishes even more quickly.

The military may also choose to remain in power and preserve order and the status quo via a police state. The official justification for such regimes is, of course, not the preservation of the status quo, but the preservation of order and social peace. Order, the argument goes, is essential for economic development; and economic development must precede the establishment of constitutional government. Thus, the important thing for the moment is to put down insurgency, develop the country's economy, and worry about constitutional government later. The country, it is said, is not ready for representative government.

Lest anyone think that these arguments are new, they were precisely the ones advanced by some of Latin America's first caudillos, including Rosas of Argentina and Páez of Venezuela. They were stated with more precision by five of the best-known strongmen of the twentieth century: Díaz of Mexico, Gómez of Venezuela, Ubico of Guatemala, Trujillo of the Dominican Republic, and Batista of Cuba. All of them provided periods of unprecedented order and notable economic development, a fact that led financial circles throughout the world to comment on the unusual wisdom of these leaders. Yet thirty years of Díaz' prosperity were followed by nearly twenty years of civil war. Thirty years of Gómez' prosperity were followed successively by a period that came seriously close to civil war and eventually developed into 
a military-leftist coup, inevitable disorders accompanying reform measures introduced by a civilian government, another rightist military coup, a bloody coup to oust that dictatorship, and an extended period of violence following further reforms under another civilian administration. The demise of Trujillo after thirty years of uninterrupted peace and economic development has left the Dominican Republic ripe for civil war, a situation with which even another military dictatorship proved incapable of coping. No North American needs to be told what followed the prosperity of the Batista regime in Cuba.

What is overlooked in the "peace and prosperity" argument is that a period of economic development helped to produce the conditions of insurgency-population explosions, urbanization, contact with other parts of the world, and better communications within a country. Yet during the same period, the institutional props capable of facing a major challenge (political parties and independent labor unions) were not developed. Furthermore, the economic prosperity reached only a small minority. It should be no surprise, then, that the demise or overthrow of the strongman was followed by a period of chaos.

Only in Paraguay and Nicaragua have regimes of this nature continued into the 1960 's. Both have developed efficient systems for dealing with the symptoms of insurgency. Secret police, a controlled press, and the arrest or exile of labor, student, and party leaders have kept potential insurgents under control. Both are among the more backward countries of Iatin America, but both are in a period of peace and relative prosperity. Whether 
they will follow the path of the countries mentioned above, or when, remains to be seen.

Finally, the armed forces might become the reformers as well as the guardians of internal security. There are few examples of this in Latin America. Colonel David Toro and Colonel German Busch in Bolivia tried unsuccessfully to set up a reformist regime in 1936. But this was to be "State socialism with the aid of the parties to the left" rather than a purely military regime. ${ }^{21}$ Colonel Juan Perón also used reform as the keynote for his regime following a coup d'état in 1943. But he soon turned to a single peronista party, largely constituted of workers, in order to balance the power of his not-tooreliable military colleagues.

More recently, military governments in Bolivia, Brazil, and Ecuador have stated their desire to see reforms instituted although under a constitutional government based on free elections. This, then, is simply a return to their role as "guardians" of the national interest. Whether this is an indication that the armed forces are now prepared to offer their backing to civilian governments with reform programs remains to be seen. If so, it is unlikely that most of the armed forces will be willing to support anything beyond very moderate changes. Given the magnitude of the social and economic problems in Latin America a large part of the civilian sector will probably find this unsatisfactory, and a period of agitation and violence will ensue. Will the armed forces then intervene?

If the armed forces become the promoters and guardians of reform, it is likely that schisms among the services, and even within the services, will be intensified. As 
in the civilian sector there will be those who oppose reform, those who support it, and those who think it should be moving more rapidly.

With respect to this problem, one critic has recently pointed out that, although the military has been the traditional bulwark of the anti-Communist crusades, military leftism has been on the crescendo in such diversified political systems as Mexico, Guatemala, Brazil, and Cuba. This has been happening in a period of a declining trend in left wing mass civilian politics, except in Chile, Bolivia, and perhaps Venezuela.

The recent violence in the Dominican Requblic emphasizes the problem of division within the armed forces. In 1965, pro-Bosch supporters in the armed forces called for a return of the exiled former president and invited civilian support. This plunged the capital into a bloody civil war that threatened to spread throughout the country. It appears to be a safe assumption that some of the weapons and ammunition distributed to civilians by members of the armed forces will be used for other attempts in the future.

Venezuelan army tanks and infantry had to be called out twice during 1962 when the navy's marine corps tried to overthrow the constitutional government. In both cases, weapons fell into the hands of civilians who have probably been using them in other parts of the country.

There have been other interservice encounters that did not involve direct civilian participation. In 1961, air force fighters routed army tanks outside the National Congress in Quito and installed their candidate for president. Two years later the Argentine Air Force destroyed 
the navy's air arm in one of a number of interservice political struggles in that country.

Edwin Martin, assistant secretary of state, pointed out this problem in 1963: "Theoretically, we could put vast amounts of arms and riot equipment into Latin American hands today to stamp out rebellion and to shoot down the Communist leaders and followers. But in whose hands would we put these arms? How can we be sure that the riot quellers of today will not be the rioters tomorrow: What good are arms and security controls in a permanently unstable society?" 22

The second dilemma that accompanied the evolution of hemispheric security doctrine is even more perplexing. Given the uncertain role of the Latin American armed forces, how could the use of military assistance, once provided, be controlled by the United States?

Presumably, the legislation authorized the use of United States aid only against Communist-inspired subversion and not against other kinds of revolutions or for other political purposes. But the problem of enforcing those restrictions remained; and, if anything, it became more difficult than ever to determine what constituted a violation. The distinction between external defense and internal security was clear, if unreal. But the line between different kinds of internal disturbances was vague and practically impossible to draw. Conceivably, anything that disrupted the stability of a country would make it more susceptible to Communist subversion and, therefore, would be a legitimate target for the use of United States military aid.

As had his predecessors, Secretary of Defense McNamara apparently recognized the danger of such unin- 
tended uses of equipment and supplies but dismissed it as of less importance for the immediate interest of the United States than the threat of a Communist take-over: "The essential role of the Latin American military as a stabilizing force outweighs any risks involved in providing military assistance for internal security purposes.' Then, as if to reassure the congressmen that the United States was not entirely at a loss to control the situation, he added, "that in accordance with congressional requirements, each internal security program for Latin America is subject to express Presidential determination in the first instance, and thereafter to continuing close policy review by the Department of State." ${ }^{23}$

Senator Gruening did not share the confidence expressed by others in the new Latin American military. He expressed the opinion that most of the Latin American military leaders would "continue to react to power struggles in their own countries in accordance with their own estimates of the situation, their own ambitions, their vested privileges, and their own heritage. Democracy," he added, "does not rub off by commingling of individuals or by grants of military assistance." ${ }^{2 t}$

Responding to growing complaints from Latin American and North American critics that the United States was befriending military dictators and assisting them to remain in power through military grants, Congress amended the Mutual Security Act in 1959. As amended, it provided that, "Internal security requirements shall not, unless the President determines otherwise, be the basis for military assistance programs to American republics." ${ }^{25}$ But the restriction could be circumvented without much difficulty by a simple determination by the 
President that internal security aid was necessary and served the best interests of the United States.

From a military standpoint, the restriction does not appear to have made much sense. Even in a conventional war, a government has to be prepared to act against fifth columns and other threats to internal order that could weaken the country's ability to conduct its defense. When, as already noted, it became known that the Communist strategy had shifted from overt aggression to covertly sponsored wars of "national liberation," it became paramount that Latin American armies undertake internal security as a primary mission. Despite testimony and other statements to this effect, and despite a report by a special study mission of congressmen that recommended that "in the Latin American area emphasis in the military field should be placed on the training of personnel for internal security and civic action programs," ${ }^{26}$ legislation continued to require that, unless the President determined otherwise, internal security should not be the objective for United States military assistance. Nevertheless, the wording of the restriction was much broader in the 1963 version and even appeared to approve of the use of United States aid against all kinds of revolutions.

Except (1) to the extent necessary to fulfill prior commitments or (2) to the extent that the President finds, with respect to any Latin American country, that the furnishing of military assistance under this Act is necessary to safeguard the security of the United States or to safeguard the security of a country associated with the United States in the Alliance for Progress against overthrow of a duly constituted government, and so informs the Congress, no further military assistance under any 
provision of this Act shall be furnished to any Latin American country. ${ }^{27}$

There are at least four methods by which such aid can be used in unintended ways:

1. Simple disregard of use restrictions. The only recourse is to take action after the fact, a step the United States has not wanted to take for fear of jeopardizing its larger interest in keeping the country in question within the hemispheric alliance. (For stipulations regarding the use of the military equipment, see Appendix $G$ for the texts of military assistance agreements and exchanges of notes.)

2. The receipt of United States military aid may relieve a country of the cost of providing for certain basic equipment and supplies and permit it to turn that savings into other kinds of equipment that can be used for unrestricted purposes. In this way, the United States contributes indirectly to those other purposes.

3. Unlike the equipment it provides, the United States cannot put use restrictions on the men it trains. This is a second and perhaps more visible way in which the United States contributes to unintended uses of military aid.

4. Whether United States aid is put to actual military use, its existence has an effect on the domestic balance of power. It is fatuous to believe that the struggle for power can be solved by assuming that the tiger will change his stripes and be converted in to a progressive, democratic force. It is naive to feel that the problem will yield to legal solutions. 


\section{Summary}

We have outlined briefly the evolution of hemisphericsecurity doctrine since 1947 and have emphasized the responses and dilemmas that accompanied it. Above all, the evolution of hemispheric-security doctrine brought with it a fresh justification for Latin American armed forces in hemispheric-defense arrangements. As defenders against a Soviet armed attack, they had never presented a very convincing picture. As defenders against internal Communist subversion and insurgency, a case could more easily be made for their existence and for improvement of their capabilities. Although some military dictators had in the past co-operated with Communists in order to destroy the democratic left, by and large the armed forces had a reputation for being fiercely anti-Communist. But, as we have noted, there were reasons for concern over the unexpected or unwanted effect of increasing the power of this politically oriented group. The search for a way out of this dilemma was at least one of a number of factors in the development of a doctrine of civic action.

1. Lucien W. Pye, "The Roots of Insurgency and the Commencement of Rebellions," in Internal War: Problems and Approaches, ed. Harry Eckstein (New York: Free Press, 1964), pp. 157-80. This chapter and others in the book were originally presented as papers for a symposium convened at Princeton University in late 1961.

2. Eugene Staley, The Futurc of Underdercloped Countries: Political Implications of Economic Development (rev. ed; New York: Praeger, 1961). 
3. New York: Holt, 1959, p. 3.

4. Edwin Lieuwen, Gencrals us. Presidents: Nco-Militarism in Latin America (New York: Praeger, 1964), p. 72.

5. Victor L. Urquidi, The Challenge of Derelopment in Latin America (New York: Praeger, 1964), p. 9.

6. General Andrew P. O'Meara, United States Army, commander in chief, United States Southern Command, Conmittee on Foreign Affairs, Hearings, Forcign Assistance Act of 1964, 88th Cong., 2d Sess. (April 14, 1964), p. 412.

7. Stanford, Calif. Stanford University Press, 1964, p. 254.

8. Today's Latin America (New York: Doubleday, 1962), p. 182.

9 Senate Committee on Foreign Relations and Committee on Armed Services, Hearings, Mutual Security Act of 1951, August 6, 1951. However, that same year Mr. Miller pointed out that: "Each American Republic agreed at the Washington meeting to strengthen its internal security against the infiltration tactics of international communism. I do not need to tell this committee that unless our partners to the South are economically and politically stable they cannot make an effective contribution to the common effort to maintain the peace and security of the hernisphere and to prevent aggression against the hemisphere." (House Committee on Foreign Affairs, Hearings, The Mutual Security Program, 82d Cong., 1st Sess. [July 25, 1951].)

10. Public Law 86-108. Section 105(b) (1), 86th Cong. (July 24, 1959), H.R. 7500.

11. This same date was used by Defense Secretary Robert S. McNamara in 1963: "Until about 1960, military assistance programs for Latin America were oriented toward hemispheric defense. As it became clear that there was no threat of significant overt external aggression against Latin America, emphasis shifted to internal security capabilities for use against Communist-inspired subversion or covert aggression and to civic action projects designed to promote stability and strengthen national economies." (House Subcommittee on Appropriations, Hearings, Forcign Opcrations Appropriations for 1964, 88th Cong., 1st Sess. [May, 1963], Part 2.)

12. President Kennedy, Foreign .lid Mcssagc, Congressional Record, March 22, 1961, Senate, p. 4470.

13. Department of State, President Kennedy's Report to the People on His Trip to Europe. Publication 7213, May 3-June 6, 1961, General Foreign Policy Series, p. 71 June, 1961. 
14. Department of Statc Bulletin, March 11, 1963, p. 347. He also noted: "Even more important over the long term will be the achievement of our goals under the Alliance for Progress, a partnership of 20 countries of the inter-American system."

15. Senate Committee on Appropriations and Committee on Foreign Relations, 4 Report on the Alliance for Progress, 1963 by H. $\mathrm{H}$. Humphrey Doc. No. 13, 88th Cong., 1st Sess. (April 11, 1963), p. 36.

16. Subcommittee on Inter-American Affairs of the House Committee on Foreign Affairs, Report, Communism in Latin Amcrica, H. Res. 84, 89th Cong., 1st Sess. (April 14, 1965), pp. 16-17.

17. General C. E. LeMay, "Strategic Advantage Is Key to All Tasks," address to Central States Shrine Association, St. Louis, Missouri, October 19, 1963, in Air Force Information Policy Letter: Supplement for Commanders, No. 125 (Washington, D.C.: Internal Information Division, SAF-OII, Pentagon, November, 1963).

18. General Robert J. Wood, United States Army, director of military assistance, International Security Affairs, OSD, speaking before the Los Angeles World Affairs Council, on December 3, 1964 (Supplcment to the Air Force Policy Letter to Commanders, February, 1965, No. 2). In the same speech he noted: "Thanks to Mr. Castro [the main threat today] is that of Communist subversion and infiltration, and not overt military aggression from outside the hemisphere. Accordingly, about one-half of the military assistance which the United States is presently providing for Latin America is devoted to equipment and training for internal security purposes, with special emphasis on counterinsurgency training." An official Military History notes, however: "Therc seemed in 1958 a greater need than ever before for versatile military forces capable of meeting challenges of varying intensity in almost every area in the world." (Amcrican Military History, 16071958, ROTC Manual No. 145-20, Headquarters, Department of the Army, Washington 25, D.C., July 17, 1959.)

19. See p. 194.

20. Lieuwen, Gencrals a's. Presidents, p. $104 \mathrm{ff}$.

21. Herbert S. Klein, "David Toro and the Establishment of Military Socialism in Bolivia," Hispanic Amcrican Historical Review, XLV No. 1 (February, 1965), 25-52.

22. Edward Martin, "Communist Subversion in the Western Hemisphere," Departmcut of Statc Bullctin, XLVIII, No. 1237 (March 11, 1963), 347-56, and XLVIII, No. 1238 (March 18, 1963), 404-12. State- 
ment made before Latin American Subcommittee of the House Committee on Foreign Affairs.

23. Subcommittee of the House Committee on Appropriations, Hearings, Forcign Operations Appropriations for 1964, 88th Cong., 1st Sess (May, 1963) Part 2, p. 84.

24. Quoted by Senator Gruening in Congressional Record, No. 14412 , 1962.

25. Public Law 86-108, Section 101(b) (1), 86th Cong. (July 24 1959), H. R. 7500.

26. House Committee on Foreign Affairs, Special Study Mission to Latin America: Peru, Ecuador, Colombia, Panama, Costa Rica, Representative Armistead I. Selden, Jr., chairman; H. Rept. No. 223, 87th Cong. (April 23, 1963), p. 46.

27. Public Law 88-205, Section 202, chap. i, Part 2, 88th Cong. (December 16, 1963). 



\section{Chapter :}

The Development of a Doctrine: Civic Action

Our analysis of the evolution of hemispheric-security doctrine must now emphasize an additional point. The emerging doctrine of counterinsurgency as it was applied to Latin America stressed the importance of rectifying those conditions that were believed to have given rise to the threat of insurgency. These included poverty, rising but unfulfilled expectations, and, in many countries, a highly unfavorable public image of governments and their armed forces. In a word, prevention! It should be no surprise, then, that military civic action was given increasing importance as a part of counterinsurgency doctrine. We have, therefore, chosen to discuss at some length the development of the concept of civic action among United States policy-makers. Three points of interest stand out with respect to the development of this concept: (1) it had a solid base in United States and Latin American historical experience; 
(2) when the great interest and impetus in Washington came (in the early 1960's), considerable groundwork in inter-American co-operation had already been laid; and (3) it showed the convergence of many interests and objectives.

\section{II}

\section{United States and Latin American Precedents}

The internal experience of the United States military in civic action in peacetime goes back to the early days of the country's history when the Military Academy, established at West Point, followed French models in curriculum and training by emphasizing engineering subjects in its courses. The graduates, in addition to entering military careers to serve with the troops, were sought as professors in civilian engineering institutions that were established later. Putting to practical use the engineering education of its officers, the government designated them to command and to staff the exploration parties that traveled through the West and to bring back invaluable data on the flora and fauna of the regions not yet part of the national domain. Army explorations were conducted by Lewis and Clark; by Pike and Long, for whom Colorado mountains were named; and by other officers whose names are especially well known in the western tier of states-e.g., Fremont and Bonneville. This military leadership and the resulting knowledge became the basis for the typically civilian activity of the nineteenth century-the westward move- 
ment. Army units were assigned to plan and locate the roads and canals needed to open the new regions for settlement and economic development. Over a period of years the army provided the needed elements of government and order in some areas. Individual officers were assigned, or were permitted, to work for the railroad builders in the closing decades of the century.

A basic report by Major Kearney in 1816 had been of considerable commercial benefit in developing coastal waterways. Major Long's report in 1816 on the transportation possibilities of the Ohio and Mississippi rivers and Secretary of War Calhoun's report to Congress the next year on roads and canals were followed by the General Survey acts of 1824. The latter act authorized the use of army engineers for canal- and road-construction duties and for improvement of the navigation of rivers and harbors. Subsequently, flood control was added to their duties. In 1849, they were given the responsibility for road-building in the Utah Territory; by 1854 that responsibility included Kansas and $\mathrm{Ne}$ braska, as well as the territories of Washington and New Mexico. In the 1830 's, some fifteen railroads were using army engineers. In the 1850's, twenty officers were detailed to chart four routes between points on the Mississippi and the Pacific Coast. In 1858, the engineers began the development of the Great Lakes navigation system.

Celebrated in history and drama, the medical investigations of Dr. Walter Reed and William Gorgas, army surgeons, contributed not only to national health but to the world's knowledge of diseases such as yellow and typhoid fevers. Navy officers and men have also been 
noted for their explorations and for scientific and educational contributions to the country, as exemplified in the Arctic and Antarctic voyages of Peary and Byrd. Navigation charts, prepared and developed by the Unite States Navy have been of immediate, practical use to commercial transportation. Studies of winds and currents, also prepared and developed by the United States Navy (in oceanography and allied fields) have produced many civilian and economic benefits. U.S. Air Force investigations and studies of meteorology, aviation, weather forecasting, and medicine, have had direct and far-reaching influences on agriculture, transportation, medicine, and other endeavors in the civilian sector. In 1922, the air force helped to improve aerial spray for insect control. It has bombed log jams and ice jams, flown serum to epidemic areas, transported food and supplies to disaster refugees, flown relief missions abroad after natural disasters, and brought Hungarian refugees to the United States in 1956.

Various kinds of temporary military duty including disaster relief, flood- and fire-fighting, establishment of law and order, and, in recent years, utilization of military forces in the Arkansas and Mississippi public-education crises - these, if not unique, were civilian oriented in purpose. In the past two decades the advances in science, health, communications, space, mathematics, agriculture, industry, and electronics gained much from the Defense Department's research and experimentation conducted directly by the military establishment through its educational or research institutions. Not every mission of the military related to civilian life has been successful, or popular. In accordance with the law of the times, the United States Army, in order to safeguard the mails, acted as strike-breaker in the Pull- 
man strike of the last century and flew the air mail in the 1930's.

The application of civic action under conditions of actual insurgency has also been a part of I'nited States military experience. In the Philippines, 1898-1905, the United States was faced with the task of governing and starting the modernization of an area that had been ruled by an unimaginative Spanish colonial regime for two hundred years. But local Filipinos aspiring to national independence collected around the leadership of Aguinaldo, who led a guerrilla-type campaign against the United States. The Aguinaldo forces felt frustrated and disillusioned and turned against their liberators as embodying a new imperialism. (On a minor scale and for a shorter time, a comparable situation prevailed in $\mathrm{Cuba}$ after the Spanish-American War.)

The Philippine guerrillas offered a stubborn and lengthy resistance to the United States. According to one account there were no less than 200,000 deathsnot all battle casualties-before the Philippine insurrection was put down. As part of the campaign against the Philippine insurrection, the United States undertook what was then considered to be a large-scale program of economic development and nation building that included school-building and teaching, road construction, medical and sanitation improvements, and governmental administration. These reforms of Spanish misrule, of rehabilitation from the wartime destruction, and the building of foundations for future economic growth were managed and administered by both military and civilian officials.

Generals Bruce Clark and Maxwell Taylor in the South Korean conflict initiated a civic-action program that succeeded in improving the relations between the 
Korean population and the United States and Korean forces. It also contributed solidly to the reconstruction of the national economy. The antiguerrilla and counterinsurgency advisory roles emphasizing military civic action in Vietnam brings up to date the record of this kind of military effort by the United States.

American historical accounts of activity in the area of counterinsurgency and military civic action regularly ignore what probably were the first such programs sponsored by the United States in Latin America. The programs carried out by the United States Marines in their occupation of Haiti (1915-34), the Dominican Republic (1916-24), Nicaragua (1912-off-and-on to 1932), and to some extent the projects undertaken by the United States Army in Cuba and Panama during brief interventions, unmistakably belong on the civicaction family tree. These early-in-the-century programs involved two kinds of activities: (1) public works and other projects carried out directly by United States military units, and (2) the training of local military or police organizations to carry on the work of the marines, including their civil functions when the occupation ended.

Only the first of these activities has been the subject of wide comment. In addition to reorganizing local governments and mounting an attack on tropical diseases, the American military government in Cuba built roads, dredged harbors, strung telegraph wires, paved streets, installed sewers, and in general carried on a comprehensive program of public works. The marines are credited with similar accomplishments in the Dominican 
Republic: Building schools; training teachers; and constructing highways, sewer systems, and communication networks. In Haiti, the occupation forces undertook a similarly wide range of civil functions, especially in the area of public health and agricultural education.

Less attention has been given to the training of local military forces. For the most part, comment has been confined to the military aspects of that training and to general remarks on United States Marine Corps efforts to encourage the professionalization, discipline, and efficiency of its Caribbean pupils. In Haiti and the Dominican Republic, United States forces sought to school their protégés in civic-type functions as well. Lieutenant Colonel Clyde H. Metcalf in his A History of the United States Marine Corps, reports that in the Dominican Republic "a tremendous effort was made to raise the efficiency of the Guardia to enable it to control the country after the withdrawal of the Marines." It is apparent from his discussion that part of that "control" involved the administration and supervision of a number of civil functions.

The Haitian Gendarmerie, also organized and trained by the marines, went even further into civilian functions:

The Haitian Gendarmerie performed a great variety of duties. It was trained as a military force and was ready to oppose groups of outlaws. It exercised all normal police functions, both lwal and national. Gendarmes supervised the clistribution of all arms and ammunition, the public lankls, travel and traffic, and weights and measures. It was their duty to prevent smuggling, collect vital statintics, enforce sanitary regulations, exercise control 
over prisons, enforce harbor and docking regulations, and, for several years, they were largely responsible for the development and maintenance of the roads and telegraph lines of the country. ${ }^{1}$

The Gendarmes also carried out sanitary engineering projects, constructed public schools, dug irrigation ditches, maintained telephone service and radio stations, and administered the lighthouse service. In the constitutional plebiscite of June 18, 1918, "The Gendarmes were ordered to try to convince the voters of its [the constitution's] desirability and give receptions and barbecues, paid for from Gendarmerie funds, to make it more popular." '2 Although the Nicaraguan occupation can be distinguished in many ways from the interventions in Haiti, Cuba, and the Dominican Republic, there too, the United States-trained Guardia Nacional undertook a variety of civil functions, notably in the medical and communications fields.

The objectives were laudable. But there were unexpected and unwanted long-range results, after temporary successes. This was the view of Dana Munro:

The replacement of the old inefficient and corrupt armies by better-trained police forces in Haiti and the Dominican Republic leelped to maintain peace but had unfortunate consequences after the American occupation ended. The efficiency and discipline of these organizations gave their officers a potential political power which only the ablest of the old style caudillos had had. . The evolution of the constabularies was a disappointment to those who hoped that they would help to promote republican government. The support of constituted governments and the discouragement of revolutions meant in practice that one party might stay in power indefinitely. ${ }^{3}$ 
Similarly, Herbert Matthews, summarizing this situation, declared that

In all five Caribbean interventions (Cuba, Haiti, Dominican Republic, Nicaragua, and Panama) the immediate results were beneficial, and in all the five the long-range results were nil or worse. We put political power in the hands of the military and made them invincible. Since the bases on which to build democracies were still not present in these countries and since the traditional concept of politics as a spoils system still prevailed, our well-meant efforts led inevitably to results like Trujillo in the Dominican Republic and Somoza in Nicaragua. ${ }^{4}$

The objectives in the Caribbean interventions parallel the major goals of civic action-internal security, economic development, and the advance of responsible government. There are other similarities. The goals now are the same as they were then: to promote a responsible and non-political military establishment; to extend the central government's authority into remote provinces; and to divert military resources into socially constructive uses, especially where there was a lack of such resources in the civilian community. If there is a similarity in the objectives and activities of the Caribbean experience with those currently proposed for civic action, may not civic action also yield similar unforeseen and unfortunate consequences?

When the great impetus and interest in civic action came from Washington in the early 1960's, considerable groundwork had been laid in Latin America also. The most obvious example of this was the tradition of some civic action in nearly every Latin American country. That tradition varied greatly from country to country, 
however, as did the attitude that the armed forces exhibited toward this kind of activity. Attitudes themselves were undoubtedly shaped by historical experiences. Some of the army units of President Gómez in Venezuela for example, had been little more than slave labor camps working with picks and shovels to build roads to the dictator's many estates. By contrast the Brazilian Army engineers have, since the days of the Empire, been a major and respected source of professional skills to which every administration has turned. In general, what is now called civic action had been chiefly the function of the armies and has emphasized engineering projects; frontier or border services; public-work constructions; land, air, and sea transportation; mail and medical services to remote areas; and sometimes education. In Chile the army engineers have for decades been the agency of the government responsible for construction and maintenance of many public works. In Paraguay, the military control of the national government over most of the years of its history made it inevitable that the military would furnish many public services, including road-building, and ranging through the spectrum of other governmental functions such as the operation of plant and animal breeding farms in the realm of agricultural experimentation.

Like services provided by any other branch of the government they usually went unnoticed. When they were noticed they might occasionally have been appreciated, but it is far more likely that most Latin Americans regarded this arm of the government as they have traditionally regarded all government-with suspicion (and probably for good reason). In Argentina the army's 
civic action made a sufficient impact to create opposition on political grounds in the late nineteenth century. The rural oligarchs, concerned over losing their grip, feared that the army's civic action in rural areas would create a dangerous bond between the military personnel and the rural inhabitants. These activities were accordingly curtailed or suspended.

\section{III}

\section{A Foundation for Civic Action in Inter-American Relations}

The decision to encourage civic action was made easier to implement because the bilateral and multilateral channels for military co-operation had already been established. The history of these arrangements has been spelled out in detail in numerous studies.' We merely note that inter-American co-operation turned to matters of hemispheric defense in the 1930's. Affirmations of hemispheric solidarity were accompanied by resolutions calling for consultation in the face of a threat to hemispheric security. Later, during World War II, bilateral agreements provided military bases for the United States in Latin America. Under the Lend-Lease Act, millions of dollars worth of military supplies and weapons were supplied to Latin American governments, and United States military training missions were sent to most of them. An Inter-American Defense Board, created as a wartime organization in 1942 , was made a permanent part of the inter-American system in 1945. Within less than a year, by October, 1945, the Defense Board had 
recommended (its powers are limited to planning and recommendation), for adoption by the member states, a policy long advocated by the United States: the standardization of organization, equipment, and training. In keeping with this concept, the Truman administration strongly urged the Congress, in 1946 and again in 1947, to pass legislation authorizing substantial United States military equipment for the Latin American governments. In both years the House approved the legislation, but it did not pass the Senate.

In 1947, the Inter-American Treaty of Reciprocal Assistance was signed at Rio de Janeiro. It stipulated mutual obligations and procedures in case of an armed attack on a member state and in case of threats to hemispheric peace or security. Later, the general realization of the dangers to all Free World countries after the attack on South Korea led to passage of the Mutual Security Act of 1951. Stimulated by Congress' authorization, the administration began negotiating bilateral agreements with Latin American governments, providing them with advisers or weapons or both. By July, 1959, the United States had training missions in nearly all Latin American countries and had provided $\$ 317$ million in grants for military aid for equipment going to twelve countries. (See Table 1 of Chapter II and Appendix G.) Seven other countries were obtaining military equipment from the United States under the reimbursement provisions of the act. ${ }^{*}$

As far as United States policy is concerned, the emphasis placed upon civic action in the early 1960's was not exactly a sudden innovation. A high ranking executive of the then International Co-operation Administra- 
tion (ICA, later the AID) informed the writers of a number of precedents. As early as 1951 in Bolivia and 1955 in Paraguay, the Institute of Inter-American Affairs advanced the idea of using local engineering battalions for economic development projects, roadbuilding, construction of parks and barracks, engineering education, shop work, and training in mechanical maintenance and repair work. United States Army men were to serve as some of the instructors in these educational programs. The Bolivian government also sought to purchase equipment such as bulldozers and road machinery for its army's engineering battalions (this was before the days of MAP grants for such purposes) ${ }^{7}$

In other countries, the presence of United States Corps of Engineers, officers in military training missions, or Military Assistance Advisory Group (MAAG) missions gave rise to suggestions that indigenous military units, particularly of engineers, could be put to more constructive use than in barracks or drill duties. The InterAmerican Defense Board, at the initiative of General Mendoza, head of the Peruvian delegation, had before it since 1958 the question of vocational training for recruits and their use in construction and colonization projects. This resulted in a 1960 resolution (number XLVII) by the board giving favorable consideration to such activities. (For the text of the Resolution see Appendix D.)

In 1958, the Office of the Chief of Civil Affairs of the Department of the Army conducted studies which determined that it was in the best interest of the United States to urge the armed forces of friendly countries to contribute to their country's social and economic devel- 
opment. That same year, the President's Committee to Study the United States Military Assistance Program (the Draper Committee) was appointed to examine and to recommend modifications in the program. Military officers, including a representative of the chief of civil affairs of the army, serving with the committee, recommended the use of indigenous military forces in the socioeconomic development of their countries. This suggestion was advanced in the final Draper Committee report of August, 1959, and was incorporated into the basic statute of the United States Congress on economic and military assistance for 1959 . The concept has carried over into subsequent statutes and amendments.

\section{IV}

\section{A Convergence of Interests and Objectives}

Ideas with respect to civic action were evolving during the late 1950's at a time when the tactical applications of civic action in counterguerrilla operations in Southeast Asia were proving themselves extremely useful. Military officers, who had seen what civic action could do in an insurgency environment, were convinced of its utility. The result was a natural alliance between elements in the military who viewed civic action as a combat tactic and civilians in both the Defense Department and the State Department who were concerned with the economic or political utility of civic action.

Within the United States, a school of thought articulated by such members of the Senate as Fulbright, Aiken, Morse, and Humphrey, had for some time advo- 
cated arms control and disarmament for Latin American countries. In the early 1950 's, the then congressman from Massachusetts, John F Kennedy, in successive years introduced amendments to pending mutual security acts to reduce the amount of military assistance to Latin America. ${ }^{8}$ Members of this school also included Latin Americans, as exemplified by Costa Rican and Chilean initiatives for hemispheric disarmament in 1948 and 1960 respectively. It was epitomized by the lectures and writings of the former President of Colombia, Senor Eduardo Santos, whose thesis was summarized by the phrase, "Each Latin American country is being occupied by its own army." " Congressional thought, however, veered from disarmament to taking action to reduce United States military assistance for Latin America, and then as a substitute advocated that such savings as might be derived from arms reductions should be applied either to (a) economic projects or (b) an interAmerican military force. In June, 1965, to the surprise of the executive departments, Chairman Fulbright of the Senate Foreign Relations Committee proposed that $\$ 25$ million of the $\$ 55$ million annual ceiling for Latin American military assistance be earmarked for an interAmerican military force under the control of the OAS. This illustrates a continuing and unique initiative by the Senate committee, as comparable proposals were made by Senator Church of Idaho and Senator Smathers of Florida in 1959 and by Senator Morse in 1961. In 1963 , the Senate's measure reiterating the same idea was modified at House insistence. ${ }^{10}$

During the 1950's, United States military thinking was shifting away from its primary concern with thermonuclear war and the doctrine of deterrence to the needs 
for balanced forces and capabilities for small and conventional wars. This tendency within the military was hastened by the Korean invasion in 1950 . It had previously been slowly advancing through the ranks of the military as the object lessons of campaigns in Malaya, Africa, and the Philippines became more clear. To this growing concern, which sharpened the quest for new military doctrine, there came the gift of Premier Khrushchev's January, 1961, declaration regarding "wars of liberation." For those who would read and listen, this was ample warning and confirmation of a need for reorientation of United States security policy.

Within the United States public, and reflected in congressional debates and appropriations, there was diversity of opinion and variation in intensity of support for foreign economic assistance and foreign military assistance. This diversity became so sharp that administration leaders decided to combine the two programs administratively, to the extent possible, under the $\mathrm{Mu}$ tual Security Administration. The joining of the two programs in the authorization and appropriation legislation, it was felt, resulted in obtaining larger appropriations for the economic projects than would have been possible if they had been presented separately without the protective covering of military assistance; (the latter gave the color of national defense and of antiCommunism to the whole administrative-legislative program). Thus military civic-action programs became at once administratively feasible-appropriations from both the military and economic assistance funds could be utilized-and, at the same time, satisfied some theoretical and ideological concepts. (The opposite way, 
i.e., to present as separate legislation the requests for economic and military aid, was again advanced by Senator Fulbright in the early months of 1965.)

It was also believed that military civic action might contain within it solutions to some Latin American internal problems, both economic and political. It would meet the contention that large standing armies were a drain on the economy; it would make full use of idle hands and idle skills within the military organization. It might even help to keep them out of politics. According to a report by Senator Aiken that process was well under way if not completed in Bolivia by 1960: "The military has been thoroughly purged of anti-revolutionary elements and set to work on a variety of civilian projects, such as road- and bridge-building. One engineer battalion even runs a sawmill. (This use of the military for civilian activities, after the manner of the Army Engineers in the United States or the old Civilian Conservation Corps, provides a model which could be usefully studied for wider application in Latin America.)" ${ }^{11}$ But the Bolivian coup of 1964 suggests that even the best purgatives are not 100 per cent effective. In 1961, the Senator noted that the dilemma resulting from the buildup of internal security forces was still a troublesome one in other parts of Latin America as is shown in the following dialogue during a committee hearing:

[Senator Aiken] And one of the purposes is to maintain friendly governments in office in these [Latin American| countries?

[General Lemnitzer] Yes, sir: this is one of the purposes in some countries. Hemispheric defense and in- 
ternal security against Castro and Communist-inspired subversion are others.

[Senator Aiken] If one of the purposes is maintaining friendly governments in office, this is a laudable ambition. However, the experience of some of those countries has been that when they got a strong military force, the military just take over the friendly government. ${ }^{12}$

A year later, following some hopeful testimony by Secretary of Defense McNamara, senators again detected some progress in resolving the dilemma:

[Secretary McNamara] Last Friday, I spent the day in Panama at the headquarters of our Caribbean Command with the ambassadors and military chiefs of several of our missions in Latin America, discussing the ways in which we can further contribute through the civic programs to the economic development of those nations. In one particular instance there is a program being developed that will, for a very small amount of money, make it possible for approximately 10,000 man-years of work to be done on vitally needed roads, water sources, sanitation facilities, school buildings and other foundations for economic growth and development.

[Senator Carlson] Mr. Secretary, with the last statement I agree thoroughly. I think that the military can play, and does play, an important part in not only Latin America, but under-developed countries, in sanitation and roads, and highways. I think that is a very fine part of the program. ${ }^{13}$

The dialogue was repeated after a statement by General William Enemark, director of the Western Hemisphere Region, OSD/ISA:

The chief emphasis in the fiscal year 1963 program will be on training, communications, transportation, and civic 
action for the ground forces; training and air transport capacity for the air forces; and antisubmarine and coastal patrol effectiveness for the naval forces.

[Senator Aiken] I have been concerned, as I know you have, over the past years lest we provide the means for arming one Latin American country against another. I know that we have both expressed a hope that there will be more conversion to engineering battalions and other plases of the military besides that of being strictly policemen. And I am glad to hear you report what proggress is being made. ${ }^{14}$

The Senator, obviously pleased to learn of the intended use of engineering personnel, did not elaborate on the comparatively small fractions of the requested appropriations that were earmarked to be used for civic action. Of considerable influence both in the executive and legislative branches of the government was the impact in 1959 of the Draper Committee Report, which has been mentioned above. Several of the supplementary sections of the report, which strongly recommended civic action, were the work of a retired Corps of Engineers officer, General Don Shingler, who brought his wide practical experience in engineering-abroad and within the United States-to bear upon the study (Colonel Lincoln, of the Social Sciences faculty at West Point arranged for General Shingler to work with the Draper Committee.) Based on the high prestige of the members of the committee and bolstered by considerable research, the report was conveyed to the public with favorable mass media commentary. It recommended

that, pursuant to the spirit of the Mutual Security Act of 1959, responsible United States agencies and officials encourage the use of foreign military forces in less de- 
veloped countries for achieving economic objectives, subject to the two qualifications that (a) such a program should not be used as an excuse to maintain military forces which are not justified for purely military reasons, and (b) the ability of military forces to carry out essential security missions, should not be significantly reduced by these proposed economic activities.

The 1960 platform of the Democratic party adopted in Los Angeles, presented to the convention by Ambassador Chester Bowles, contained more than a hint of party sponsorship of civic action. A section entitled, "The Underdeveloped World," promised:

Where military assistance remains essential for the common defense, we shall see that the requirements are fully met. But as rapidly as security considerations permit, we will replace tanks with tractors, bombers with bulldozers, and tacticians with technicians. The Democratic programs of economic cooperations will be aimed at making it as easy as possible for the political leadership in these countries to turn the energy talent and resources of their people to orderly economic growth.

\section{The Democratic Platform of 1964 declared:}

Since . . 1960 we have created a balanced versatile, powerful defense establishment, capable of countering aggression across the entire spectrum of conflict from nuclear confrontation to guerrilla subversion. Since 1961 we have trained over 100,000 officers in counter-insurgency skills necessary to fight guerrilla warfare, and increased our special forces training to deal with counter-insurgency by 800 per cent.

After only six weeks in office President Kennedy announced the Alliance for Progress as a major decade- 
long measure for economic development by democratic means, and his hope to enlist the support of the governments and of the peoples of the other countries of the hemisphere. The original statement by the President on March 13, 1961, included a significant phrase:

And the new generation of military leaders has shown an increasing awareness that armies cannot only defend their countries-they can, as we have learned through our own Corps of Engineers, help to build them. ${ }^{16}$

In his aid message nine days later he stated in his request for funds for foreign aid:

. To the extent that world security conditions permit, military assistance will in the future more heavily emphasize the internal security, civil works and economic growths of the nations thus aided. By this shift in emphasis we mean no lessening of our determination to oppose local aggression wherever it may occur. ${ }^{17}$

Simultaneously, the President charged Secretary of Defense McNamara with general, total, and specific review of internal security and strategy.

The United States Corps of Engineers provided a useful example that the President could emphasize. In his "Urgent National Needs" message to the Congress on May 25, 1961, he stated:

Military assistance can, in addition to its military purposes, make a contribution to economic progress. The domestic works of our own Army Engineers are an example of the role which military forces in the emerging countries can play in village development, sanitation, and road building. ${ }^{18}$ 
Secretary of State Rusk joined in setting up the concept and prestige of the Engineers Corps as a model for Latin America :

The U. S. Government would like to see Latin American armed forces increase their part in modernizing the basic facilities of all the American Republics. We believe they could borrow profitably from the long and honorable record of our own U. S. Army Corps of Engineers, in strengthening the civilian economy. ${ }^{19}$

This highly favorable view of the military engineering function-if not the institution-was reiterated by the well-known, Spanish-Mexican author, Victor Alba:

Latin America ought to put the thousands of military technicians to work. What they learn in schools-the capacity to undertake enterprises, to plan public works and direct their execution-covers many of the technical problems that still remain unresolved not only for want of money, but also for the lack of professional skills. The army that Latin America needs-and this is not a demagogic phrase-is an army of engineers, of overseers, of constructors. ${ }^{20}$

General Maxwell Taylor, with many years service in the Corps of Engineers, is known to have exercised substantial influence in the Kennedy administration, in his capacity as special military adviser in the White House and subsequently as chairman of the JCS. His influence was direct and strong in favor of civic-action programs in the underdeveloped countries in general, and in Latin America in particular. It was perhaps more than a coincidence that many of these programs would fall under the supervision and management of the Corps of 
Engineers officers. The Armed Forces Assistance to Korea program (AFAK), was established in August, 1953, by General Bruce Clark and General Taylor, then commander of the Eighth Army in Korea. The latter had proposed through a letter to Assistant Secretary of Defense John A. Hannah that surplus construction materials worth $\$ 15$ million be used by the United States military personnel to help Korean reconstruction. President Eisenhower approved the plan, as did the United States Congress in November, 1953, which appropriated $\$ 20$ million for its support. Closely tied to the self-help concept, a priority among projects was established: (a) schools, (b) public health, (c) orphanages, (d) civic buildings, (e) public utilities, and ( $f$ ) bridges. General Taylor's assistant chiefs of staff were navy and air force officers who implemented the congressional mandate. The UN later undertook comparable activities, but on a temporary basis.

The parallel role of Congress also must be taken into account. In the Mutual Security Act of 1959 previous policy was broadened to include a rather wistful hope for administrative action that later became known as civic action. The act stipulated that: "To the extent feasible and consistent with the other purposes of this chapter, administrators of the military assistance program shall encourage the use of foreign military forces in underdeveloped countries in the construction of public works and other activities helpful to economic development." ${ }^{21}$ The following year the Senate Committee on Foreign Relations reiterated its view "that the military assistance program to Latin America, including training, should be carried out, as far as possible, with emphasis 
on the performance of economically useful civil functions by the military." Then, referring to the relevant legislation, it observed:

This implies training in engineering and assistance for military engineering units. Something has already been done along this line, and the committee hopes that more progress can be made, not only in Latin America, but also in other less developed countries. The kind of work involved is primarily construction of such things as roads, harbors, bridges, and airfields, roughly similar to some of the things done by the Army Corps of Engineers in the United States. ${ }^{22}$

In reporting on a 1965 amendment to the Foreign Assistance Act, the Senate Committee on Foreign Relations noted that, insofar as practicable, foreign military forces should not be maintained solely for civic-action activities. The committee observed that such activities should not detract significantly from the capability of military forces to perform their military missions and should be co-ordinated with, and form part of, the total economic and social development of the country concerned. The committee concluded that economic development is of great importance to the defense and internal stability of less developed countries, and civic-action efforts such as the type envisaged by the amendment should be encouraged. In addition to speeding the economic development of the recipient country, these activities were reported to "improve relations between civilian populations and their military forces and provide on-thejob training for members of military engineering units." 23 


\section{Professional and Competitive Interests in Civic Action}

United States military personnel have not written in the professional journals or often testified before the Congress regarding the strictly military purposes which might be carried out by their service abroad in counterinsurgency or civic-action billets. But as Commander C. F. Krickenberger, Jr., director of the navy's Construction Force Office, pointed out in a 1962 conference on the navy's role in Latin America: "Use of our forces in the $\mathrm{C} / \mathrm{I}$ [counterinsurgency] program will provide us a greater likelihood of our Naval construction forces being in or near an area where they're liable to be required if trouble erupts. At the same time, of course, we are learning about these areas. We are gaining intelligence about these areas." 24

Furthermore, civic-action and counterinsurgency missions are consciously used in an experimental way to test and perfect various United States military doctrines and techniques. General Maxwell Taylor, referring to United States advisory missions in South Vietnam, told a House Subcommittee:

Here we have a going laboratory where we see subversive insurgency, the Ho Chi Minh doctrine, being applied in all its forms. This has been a challenge not just for the armed services, but for several of the agencies of Government, as many of them are involved in one way or another in South Vietnam. On the military side, however, we have recognized the importance of the area and have consciously used it as a laboratory. We have had teams out there looking at the equipment requirements of this kind of guerrilla warfare. We have rotated 
senior officers through there, spending several weeks just to talk to people and get the feel of the operation, so even though not regularly assigned to Vietnam, they are carrying their experience back to their own organizations. ${ }^{25}$

It may be too soon to ascertain the verdict of history. But there are many - including United States military of high rank-who think that the experimenting and testing of the counterinsurgency, civic action, and conventional army doctrine and techniques have lasted in that unhappy land long enough to warrant a negative judgment as to their efficacy in yielding acceptable results.

The interest of United States military men in civic action is not always entirely selfless and public spirited. Human as they are (and bureaucrats in the bargain) they have not been above asking of the program, What's in it for us? An obvious answer to that query is new duties, with the additional personnel, funds, and authority that such duties would entail. Institutional loyalties and ambitions being what they are, it is not surprising that some service bureaus have risen to this lure. Thus, Rear Admiral N. J. Drustrup, deputy and assistant chief of the navy's Bureau of Yards and Docks, during a 1962 conference of navy officers, candidly listed among the motives for the bureau's participation in civic action, the "opportunity to increase the capability of the Bureau and the Navy Civil Engineers Corps in the face of a diminishing construction program." ${ }^{26}$ Every effort is made by the Bureau to promote "the expansion of the Navy Civil Engineer Corps' assistance to the counterinsurgency civic action programs in Latin America," by encouraging other government agencies such as AID, 
to make use of its services. ${ }^{2 \tau}$ Ideas were expounded on the ways and means of eliciting from Latin American governments, requests for United States $\mathrm{Navy}$ assistance and personnel. An appealing thought that was seriously advanced was that through civic action, navyto-navy (not to the public) assistance could be rendered and relationships improved. As one benefit of the program, it was pointed out that the bureau had been able to "retain some senior Petty Officers that would [otherwise] have gone out of the service."

Another motive for emphasizing civic action stemmed from the personal interest in the program expressed by President Kennedy. (It can never hurt to show an active concern with the boss's pet project.) Accordingly, Admiral Drustrup underscored White House interest in the program when addressing a conference of Navy officers in September 1962: "This program has the strong interest of President Kennedy. we understand President Kennedy is personally interested in finding an immediate and favorable solution to the problem of how the military will assist AID in its world-wide activities. We are therefore, in a program that has high-level inter"st and support." 28 The purpose of the navy conference was clearly stated in the title page of the report: "Objective of Chief of Civil Engineers Latin America Conference. The formulation of a plan for providing increased Naval Civil Engineering assistance in the counterinsurgency program for Latin America."

That comparable institutional interests entered into the calculations of other United States services and agencies involved in the program is known from information regarding the air force, ${ }^{2 \theta}$ Army Corps of Engi- 
neers, and others. Indeed, with an increasing number of agencies participating in civic action, it is inevitable that there should be instances of interagency and interservice competition. In interviews and correspondence civilian and military officers who have spent some years in civicaction assignments freely refer to competitive-as well as co-operative-activities of different agencies and services. Without making unhappy comparisons, it has also become clear to the authors as this study progressed, that different civilian and military bureaucrats recall that it was their own initiative that persuaded another slow moving agency to undertake civic action. Later, each claimed credit for having put civic action programs into effect at an early date. Some of the confused claims and counterclaims can be explained on the basis of timing or semantics: 1960 was a time when the phrase "civic action" was used to describe functions that the military had for many years fulfilled.

\section{Opposition to Civic-Action Programs}

There were elements in the branches of the United States services that objected to the concept of military civic action. The objection was, in some cases, based on the fear that the new activities to which the troops might be assigned would detract from their military bearing, and that the result would be a detraction from their military strength and a reduction in the time allocated to strictly military training and drill. Some of the arguments advanced were specious-such as the length of time the recruits remained in active service. Where the recruit's stint is two years or even one, the question still remains: Wouldn't that time be better spent in a 
constructive civic-action project than in close-order drill or on guard or barrack duty? Some objections arose no doubt from the military's own traditions and, in some cases, a right-about-face attitude was assumed when the word was given that the President and his military adviser, General Maxwell Taylor, took strong personal interest in the program. In this regard, Mr. Stewart Alsop related:

If a Communist-supported guerrilla movement is to be resisted effectively, there must be a solid basis of resistance within the threatened country. But the weapons and the military expertise can be provided from outside. This is the chief reason why Kennedy has insisted on a greatly expanded guerrilla and anti-guerrilla training program. At first he met the sullen opposition of the conventionally trained military men in the Pentagon, and this irritated him. But the Kennedy message is beginning to get through. "They're beginning to recognize the nature of the problem," Kennedy says, "And what they're doing at Fort Bragg is really good." 30

During a number of conversations and in correspondence with the authors, officers holding important civicaction assignments both before and after 1960 have indicated that there was opposition to the idea and a slowness in its acceptance in their respective services. A United States foreign assistance official thought in the early 1950's that the use of army engineers would be productive but did not succeed in getting any assigned to enonomic development projects. Some State Department officers were reluctant and skeptical of the whole concept, fearing that any addition to the power and prestige of the military in Iatin American would result only in an increased political role in the government. An 
experienced observer thinks that both diplomatic and military officers in the United States had misgivings. ${ }^{31}$ After the program was officially up-graded by presidential vigor in its presentation, with the Special Group cutting red tape to guarantee counterinsurgency and civic-action operations at high speed and with Attorney General Robert Kennedy following up on performance, the lesser ranks acquiesced and even accused other agencies of delay and reluctance in embracing the newly popular program.

It is probable that similar difficulties of competition and collaboration characterized the behavior of the Latin American military as they approached the modifcations in traditional norms and procedures incumbent upon the adoption and strengthening of counterinsurgency and civic action. United States military officers and civilians with considerable experience in these matters have stressed to the authors that Latin American opposition to civic-action programs has come from two different sources, one passive and one active. The former arises out of the apathy of Jatin American military who feel that civic action detracts from their ability to defend their country by diverting military personnel and effort into what are essentially civilian tasks. This attitude is reflected in Resolution XIVII of the Inter-American Defense Board, which, after recommending that highway and colonization projects be undertaken by the Armed Forces, quickly hedged about the recommendations: "The use of military personnel for this purpose, to the extent and degree that the specific condition in each country may determine, should not compete with private civilian activity nor decrease the capability of their Armed Forces for the accomplishment of their specifi- 
cally military risks required by the General Military Plan." (For full text of Resolution XLVII, see Appendix D.)

An even more active opposition has, on occasion, risen to a high pitch by business interests whose affairs-and profits-were felt to be threatened by incursions of the military. Paraguay and Venezuela have been reported as countries where opposition on these grounds came from building and road construction contractors. It will be noted that the Inter-American Defense Board's Resolution XLVII quoted above also makes provision for the safeguarding of private enterprise.

\section{V}

In the case of military civic action one cannot speak of a program developing as the result of a doctrine. Program and doctrine developed simultaneously, although the doctrine gave greater impetus to the program in the early 1960's. The first Civic Action Military Training 'Team (самтT) was sent to Guatemala in November, 1960. This was the result of an army study of 1959 (approved in May, 1960), which developed a "low-cost, no-cost" program. It merely meant that the major army contribution would come in the form of advice and assistance from military assistance advisory groups, military mission members or the small camtr's. The Guatemalan experience soon showed that more funds would have to be made available. In January, 1962, another camtr sent to Ecuador found itself handicapped in the same manner. It was that very month that the $W$ ashington Post reported that: "President Kennedy has approved in principle the limited introduction of a con- 
troversial, Pentagon sponsored foreign-aid program known as "military civic action." The army, the article went on to say, was authorized to prepare specific programs for assisting the armed forces of Communistthreatened underdeveloped countries to carry out economic and social development projects in their respective countries. It was stated that each program would have to be approved by the President, ${ }^{32}$ after careful review by the White House, State Department, and top Pentagon officials before being adopted. The report that long standing differences over this type of military aid had been settled by the administration was considered by the Post to be a fact of far reaching importance.

As the concept of military civic action emerged, what function or role was assigned to it-counterinsurgency, nation-building, economic development, improvement of the public image of the local military or of the local government, or improvement of civil-military relations? It soon became clear that almost any function or role one cared to ask about (especially if one were a member of a congressional committee), that was one of the roles that civic action could fulfil. According to statutes it was supposed to be "helpful to economic development" but only "to the extent feasible and consistent with other purposes." According to Secretary of Defense McNamara it was supposed to be "an indispensable means of establishing a link between army and populace." Secretary of State Rusk believed it would assist "in modernizing the basic facilities of all the American Republics" and "in strengthening the civilian economy." Keeping the local military busy (and perhaps out of politics), strengthening military ties across national borders (navy-to-navy, army-to-army), intelligence 
gathering, educating the military, making them aware of the problems in rural areas of their respective countries, and getting a larger share of the budgetary piethese were some of the less publicized purposes for civic action. With respect to the latter purpose, a rather unusual argument was advanced by a United States foreign service officer:

Although the world is in no danger of running out of crises, it does appear as though the USSR has concluded that its interests will not be advanced by a major war. This nuclear stand-off must inevitably lead to a gradual thinning out of standing armies. As this occurs, pressure will mount for a cutback in our own forces, and thus the freeing of some military resources. Precedent requires that those responsible for our national security resist any inordinate demobilization. To stand up to demands for reduction in the numbers now in uniform, U.S. military planners will be casting about for new missions to perform. This has already taken place in the enlargement of Army Special Forces. And such a search for missions would also favor an expanded Civic Action role.

In conversations, one or more of these functions or roles were emphasisized by United States officers in the field, although they nearly always betrayed a special interest in economic development. What or whom among these sources could say what is the function of civic action? Perhaps everyone and no one.

1. Clyde H. Metcalf, A History of the United States Marine Corps (New York: Putnam, 1939), p. 390.

2. Dana G. Munro, Intercention and Dollar Diplomacy in the Caribbean, 1900-1921 (Princeton: Princeton University Press, 1964). p. 370 . 
3. Ibid., p. 540 .

4. Herbert Matthews, "Diplomatic Relations," in The United States and Latin America, ed. Herbert Matthews (Englewood Cliffs, N. J.: Prentice-Hall, 1963), p. 126.

5. Informative treatments of the long and sometimes tortuous history of the development of the hemisphere's security policy are to be found in Charles G. Fenwick, The Organization of American States (Wash. ington, D. C.: Kaufmann, 1963) ; J. Lloyd Mecham, The United States and Inter-American Security, 1889-1960 (Austin: University of Texas Press, 1961); Ann Van Wynen Thomas and A. J. Thomas, Jr., The Organization of American States (Dallas: Southern Methodist University Press, 1963). Military relationships between the United States and the Latin American countries are brought reasonably up to date in Edwin Lieuwen's Arms and Politics in Latin America (New York: Praeger, 1961); and Generals vs. Presidents: Neo-Militarism in Latin America (New York: Praeger, 1964). Useful governmental publications on aspects of inter-American military affairs are: The InterAmerican Military Cooperation Act, House Committee on Foreign Affairs, 79th Cong., 2d Sess., Rept. No. 2230; Department of State Bulletin, Vol. XXVIII, No. 718, (March 30, 1953); Subcommittee on Disarmament of the Senate Committee on Foreign Relations, Control and Reduction of Armaments, Disarmament, and Security in Latin America, Staff Study No. 7, 85th Cong., 1st Sess. (May 12, 1957); Military Assistance Program: Information and Guidance published by the Departments of the Army, Navy, and the Air Force; Military Assistance Bilaterals, published by the air force; United States-Latin American Relations, compilation of studies prepared under the direction of the Subcommittee of American Republics Affairs of the Senate Committee on Foreign Relations, 86th Cong., 2d Sess. (August 31, $1960)$, Doc. 125. Recommended articles on specific, more limited subjects are: "Arming the Americas," Editorial Research Reports, Vol. XI, No. 18, October 31, 1947; "American Wartime Objectives in Latin America," by Edgar S. Furniss, Jr., in World Politics, Vol. II, No. 3, April, 1950; "Arms Aid to Latin America," by Jeanne Kuebler, Editorial Research Report, Vol. II, 1962.

6. "Post World War II Political Developments in Latin America," in Senate Doc. No. 125, U. S.-Latin American Relations, 86th Cong., 2d Sess. (Aug. 31, 1960), p. 39.

7. In testimony of Lieutenant General C. L. Bolte, Senate Committees on Foreign Relations and Armed Services, Joint Hearings, Mutual Security Act of 1951, May 6, 1951, p. 397. 
8. Congressional Record, August 17, 1951, p. 10291, quotes Mr. Kennedy, during House debate on the Mutual Security Act of 1951, as follows: "Mr. Chairman, the $\$ 40,000,000$ that is referred to here is for military assistance to 'the Inter-American Republics' which means the countries of Central and South America. I do not object to giving them economic assistance, but I see no point in giving them $\$ 40,000,000$ of military assistance when there are countries which are not in the line of Soviet advance, especially when it has already been said by the Committee that the great need for Western Europe is for military equipment. We need equipment ourselves. What is the use of tying up $\$ 40,000,000$ worth of military equipment in Central and South America: I would suggest it might be even feasible to cut it out completely, but there may be some use for it so my amendment proposes to cut military assistance from $\$ 40,000,000$ to $\$ 20,000,000 \quad \therefore$ See also the Congressional Record of June 28, 1952, p. 8493, in which he repeated the same line of argument and sought by an amendment to the next year's Mutual Security Act to reduce the amount of military assistance to Latin America by $\$ 20$ million.

9. See an article entitled "The Defense of Freedom in Latin America," by Eduardo Santos, in the volume Responsible Freedom in the Americas, ed. Angel de Rio (Garden City, N.Y.: Doubleday, 1955). For a carefully documented article by Michael J. Francis, see "Military Aid to Latin America in the U. S. Congress," in Journal of InterAmerican Studies, VI, No. 3 (July, 1964), 389-404. Another treatment is Captain David H. Zook's, "United States Military Assistance to Latin America in Air University Rezicw, XIV, No. 4, (SeptemberOctober, 1963), 80-85.

10. See Sen. Rept. No. 412, "The Mutual Security Act of 1959," 86th Cong., 1st Sess. (June 23, 1959). Part 2 contains the minority views of Senator Morse.

11. Senate Committee on Foreign Relations, Latin America: Venesucla, Brazil, Pcru, Bolivia, and Panana, report of Senator George D. Aiken, 86th Cong., 2d Sess. (February 2, 1960), Committee Print.

12. Senate Committee on Foreign Relations, Hearings, International Development and Security Act of 1961, 87th Cong., 1st Sess. (June, $\left.1961^{\prime}\right)$, p. 669.

13. Senate Committee on Foreign Relations, Hearings, Foreign Assistance Act of 1962, 87th Cong., 2d Sess. (April 9, 1962), pp. 76-77.

14. Ibid., pp. 407-8.

15. Composite Report of the President's Committee to Study the United States Military Assistance Program, I (August 17, 1959), 167. 
16. President Kennedy Speaks on the Alliance for Progress. Pamphlet containing address at the White House before Latin American diplomats, members of Congress and their wives, March 13, 1961, p. 9.

17. Congressional Record, President Kennedy's 1961 Foreign Aid Message, Senate, March 22, 1961, p. 4470.

18. Congressional Record, "Urgent National Needs," Address of the President of the United States H. Doc. 174, H. Rept., May 25, 1961, p. 8880.

19. Remarks by Dean Rusk at the dedication of the Inter-American Defense College, October 9, 1962, Department of Statc Press Release, No. 609, p. 2.

20. Victor Alba, El militarismo: Ensayo sobre un fenómeno políticosocial iberoamericano (Mexico City: Editorial Cultura, 1959), p. 91. In "Ten Nation Progress Report," by Lieutenant-Colonel A. J. Auletta in Army', July, 1963, p. 54, Colonel Auletta referred to the extensive public-works program carried out for years by the Chilean Army's Engineers Work Corps. He also wrote of the non-commissioned offcers of the United States Army's Corps of Engineers who gave guidance to Ecuadorean military units engaged in construction of irrigation and potable water systems, farm-to-market roads, and municipal street repairs.

21. Public Law 86-108, 86th Cong. (July 24, 1959), H. R. 7500.

22. Senate Committee on Foreign Relations, The Mutual Security Act of 1960, Rept. 1286 on S. 3058, 86th Cong., 2d Sess. (1960).

23. Senate Committee on Foreign Relations, Foreign Assistance Act of 1965, Rept. on S. 1837, 89th Cong., 1st Sess. (April 28, 1965).

24. "Report of the Chief of Civil Engineers, Latin American Conference," September 10-11, 1962, issued by the Navy Department, Bureau of Yards and Docks, October 15, 1962, p. 16.

25. Subcommittee of the House Committee on Appropriations, Hearings on Department of Defonse Appropriations for 1964, Part 1, February 13 , pp. $483-84$.

26. Rear Admiral N. J. Drustrup, Address in "Report of the Chief of Civil Engineers, Latin American Conference," September 10-11, 1962, issued by the Navy Department, Bureau of Yards and Docks, October 15, 1962 , p. 6.

27. Commander R. J. Klingenmeier, in "Report of the Chief of Civil Engineers," p. 69. 
28. Rear Admiral N. J. Drustrup, in "Report of the Chief of Civil Engineers," p. 69.

29. "One of the major efforts of the U.S. Air Forces Southern Command centers on encouraging Latin American air forces to adopt aggressive public service programs, which identify their military forces with projects designed to accomplish social and economic improvements."-From an undated brochure on Preventive Medicine Program by Office of Information, Headquarters, United States Air Forces Southern Command, Albrook Air Force Base, Canal Zone (1964).

30. Stewart Alsop, "Kennedy's Grand Strategy," in the Saturday' Evening Post, CCXXV, No. 13 (March 31, 1962), 11-16.

31. Robert J. Alexander, Latin American Politics and Government (New York: Harper, 1965), pp. 95-96: "North American diplomatic and military officials had some misgivings about the counterinsurgency aspects of their new policy. Its general application throughout the hemisphere would result in the strengthening of dictatorships such as those of the Somozas in Nicaragua, General Stroessner in Paraguay, and Dr. François Duvalier in Haiti, who were threatened more by democratic opponents than by Fidelistas or Communists. If not applied judiciously, the counterinsurgency program could intensify rather than end the mistakes of the United States military aid program to Latin America of the 1940's and 1950's."

32. This comment illustrates at one time both the direct personal impetus placed behind these activities by the President and the lack of interagency machinery for implementation of policy decisions since the abolition of the Operations Co-ordinating Board early in 1961. 



\section{Chapter 4}

Administrative and Planning Agencies:

A Program without a Bureaucracy

For important functions of governmental administration, it is well known that the manner and means of execution, implementation, and co-ordination with different power-centers in Washington are elements essential in determining the success or the failure of the function. Inasmuch as counterinsurgency is generally considered in the realm of military tactics, the absence of a bureau, commission, or board charged with these activities is perhaps understandable. Yet, in the way that counterinsurgency doctrine is applied to Latin America it is in large part concerned with preventing or rectifying those conditions under which insurgency might arise. It is to that extent more than a military tactic. Not only does it require the co-ordination of activities of many agencies, all indications are that such co-ordination will be required over an indefinite period in the future. 
In the case of civic action, the absence of a statutory bureau, commission, or board to shape its policy; to determine its philosophy; to seek for it the necessary funds; and to be its spokesman in appealing for congressicnal or White House support, surely is an item of importance. Not only is there no legislation or executive order placing such authority to be found, there is also no publicly stated interagency machinery for originating, planning, co-ordinating, and implementing the program. This is unique in Washington where there may be found various bureaucracies operating at full capacity, albeit without any very clear-cut objective, nor perhaps in response to a needed function. "A bureaucracy in search of a function" may well be a time-worn Washington joke, but the creation and supervision of the military civic-action function is strangely bereft of a publicly known bureaucratic base upon which to mount its operations.

Perhaps there would be no need for a separate interdepartmental board if one could assume that at each working, operational, planning, and policy level adequate liaison is maintained between the International Security Affairs office (ISA) of Defense Department and the State Department's deputy assistant secretary of state for politico-military affairs (G PM) in the Office of the Deputy Undersecretary for Political Affairs. But there is also in the Defense Department the Joint Chiefs of Staff with a special assistant for counterinsurgency. There are the responsibilities of UsCONARC for training. There are the IADB and the Army, Navy, and Air Force colleges. Within the Department of State, there is the Office of American Republics Affairs, whose head is 
also special adviser to President Johnson on Latin American Affairs and United States co-ordinator for the Alliance for Progress. There is also the ubiquitous cia. Also concerned in Latin American affairs is the InterAmerican Committee for the Alliance for Progress (cIap). There are the Export-Import Bank and the financial agencies of IBRD and IMF, wherein the departments of Treasury and Commerce might wish to influence decisions regarding Latin America. Finally, there is the Food for Peace Program and the Department of Agriculture's activities under Public Law 480. By sending food that local officials could distribute in payment for labor on public-works projects, these programs could greatly expand the impact and effectiveness of Latin American civic action. Casual friendly telephone calls between DOD ISA and the Department of State are scarcely adequate in this context to obtain and maintain government-wide enthusiasm and co-ordination necessary to the successful operations of counterinsurgency and civic action, which are as wide in their scope as they are shaky in their legislative foundation.

It is not proposed that a new bureaucracy be created in Washington. But at present, the administration and co-ordination of the counterinsurgency effort and of the civic-action component is vested in an organization that is not in continuous or daily session. There are many reasons for obtaining closer inter-departmental harmony in carrying out these objectives. Any one of several remedies could be applied, such as the designation of one individual-presently in the government-to be the responsible co-ordinator. Alternatively the designation of an interdepartmental committee similarly made up of 
individuals now in governmental service, could perform the necessary functions. If, as may be the case, a classification of secrecy surrounds the existence and operations of a co-ordinating entity, the problem is of a different nature. This would involve the public's right to know of the existence of such an agency.

\section{Administration in Washington}

Prior to the Kennedy administration, there existed an interdepartmental organization, the Operations Coordination Board (OCB), whose chief function was to co-ordinate and supervise governmental activities in national security matters. Particularly during the Truman and Eisenhower administrations, the OCB was given large responsibility for follow-up work to see that the decisions taken by the President and by the National Security Council were put into effect. The OCB, in its necessarily unpleasant duty of checking, supervising, and insisting upon implementation of agreedupon decisions, over a period, came to be the target of complaints of officiousness, of being meddlesome, and of offering an opportunity for Washington-bound subordinate bureaucrats to criticize and castigate high-ranking officials, especially those concerned with overseas operations. Although it is not known to the authors to what extent President Kennedy was aware of these difficulties and criticisms during his years as senator, it was one of his earliest decisions upon taking presidential 
office to abolish the OCB. To abolish the organization however, did not bring to an end the necessary function for which it was created: co-ordination and check-up to insure fulfilment of executive decisions.

The new President, running into a period of hard decisions and spectacular failure of interagency co-ordination in the invasion of Cuba in March, 1961, would hardly have been expected publicly to acknowledge that an error had been committed in the abolition of the OCB. Since the function remained, what was to be done? In part, the President by a statement at the time of abolishing the $\mathrm{OCB}$ laid considerable co-ordinating responsibility on the secretary of state. ${ }^{1}$ An additional measure was the creation of a co-ordinating and implementing body, smaller in size and different in title. Its creation was made plausible by the Cuban, Congo, and Asian crises then demanding attention. Its meetings and decisions understandably, if not necessarily, were kept largely from the public gaze.

\section{The Special Group (Counterinsurgency)}

Thus, shrouded in considerable mystery (to which some journalists contributed even while revealing some of the basic facts of the membership of the organization and its functions) came the Special Group for counterinsurgency. The Special Group appeared to be an outgrowth of the committce (consisting of Attorney General Robert Kennedy; the Director of the CIA Mr. Allen Dulles; Admiral Arleigh Burke; and General Maxwell Taylor), which President Kennedy created to inquire into the Bay of Pigs disaster in 1961. Out of that investi- 


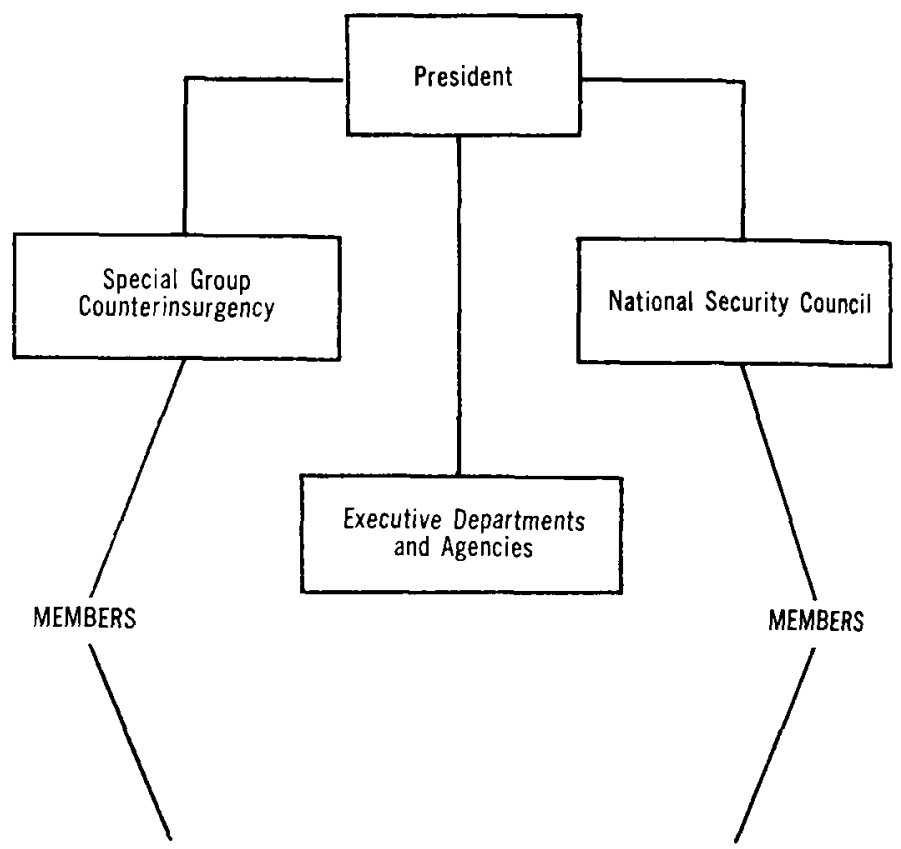

State Department, Chairman

Attorney General

Department of Defense

Joint Chiefs of Staff

Central Intelligence Agency

Agency for International Development

United States Information Agency

Special Assistant to the President for National Security Affairs
President

Vice-President

Secretary of State

Secretary of Defense

Director, Office of Emergency Planning

OFFICIALS:

Special Assistant to the President for National Security Affairs

Executive Secretary

FIG. 1.-Composition and organization of the Special Group for counterinsurgency. (Military Review, XIV, No. 4 (April, 1965), 27.) 
gation came a recommendation for the creation of a high-level co-ordinating group to supervise all governmental activities in counterinsurgency and comparable situations of unconventional warfare activities. It was called "a sort of Joint Chiefs of Staff for the control of all agencies involved in counterinsurgency" by General Taylor. Created by President Kennedy in January, 1962, the Special Group's membership included Attorney General Robert Kennedy, Deputy Undersecretary of State for Political Affairs Alexis Johnson, Director of CIA Mr. McCone, Chairman of the Joint Chiefs of Staff General L. L. Lemnitzer, Deputy Secretary of Defense Roswell Gilpatrick, the Foreign Aid Administrator Fowler Hamilton, Director of the United States Information Agency Edward Murrow (invited to join in August, 1962), and Special Assistant to the President for National Security Affairs McGeorge Bundy. ${ }^{2}$ The chairman was General Maxwell Taylor, then military adviser to the President.

Subsequently, Mr. Averell Harriman became chairman and continued in that capacity through 1965 after resigning as deputy undersecretary of state. Nominally a member, Attorney General Katzenbach did not attend meetings in 1965. This tends to corroborate newspaper reports that Robert Kennedy was the energizing force within the Committee in 1962 and 1963.

The Special Group customarily met every Thursday afternoon in the executive office near the White House (formerly the War, State, and Navy department building), with two basic functions. One was to achieve co-ordination and to speed up the action within the government agencies in order to implement policy de- 
cisions regarding counterinsurgency programs in various parts of the world. The second function was to initiate and supervise research and examination of new ideas, doctrines, and techniques for counterinsurgency purposes. An example of the first function was a survey made of the police systems in underdeveloped nations, with a view to determining what the United States might be able to do in the way of an international police academy for the education and improvement of such police forces. In September, 1961, the President had instructed AID to set up a Police Academy for Latin America. But when administrative difficulties ensued in February, 1962, the Special Group was asked to expedite the project with the result that later in the year an Inter-American Police Academy was started at Fort Davis in the Panama Canal Zone. The academy was later transferred to Washington, where a number of sessions of the courses have now been completed.

Illustrative of the second function (the supervision of research and examination of new ideas, doctrines, and techniques for counterinsurgency purposes) was the decision to increase counterinsurgency training within the United States Government and to insist that representatives of United States agencies abroad develop a single co-ordinated plan for combating Communism. This last decision resulted in the creation of a system of Internal Defense Plans (IDP), which will be discussed later.

According to the Wall Street Journal, the Special Group decided that co-ordination of counterinsurgency efforts abroad should be effected through greater emphasis upon the Country Team collaborative process. ${ }^{3}$ The Country Team, informally structured several years earlier, consists of the chief representatives of the em- 
bassy, the military attachés, the Usia, the AID, the CIA, military missions (or MAAG's), and of other agencies represented in the foreign country. It meets frequently under the close supervision and leadership of the ambassador. At least one observer has credited the Special Group with considerable success: (1) in settling disputes within the Country Teams; (2) in acting on the teams' recommendations; (3) in guiding the teams by defining their aims, and $(t)$ in initiating measures to spur a variety of counterinsurgency operations. ${ }^{*}$

The Special Group also insisted that specialized counterinsurgency training be given to United States military and civilian officers before assuming their field assignments abroad. Out of this came the Interdepartmental Seminar, conducted by the State Department's Foreign Service Institute. (See Chapter V for a description of the Seminar.)

The membership and functions of the Special Group were summarized by a member of the faculty of the United States Army Command and General Staff College as follows:

Established at Executive level and comprised of highranking members from those departments and agencies primarily concerned with foreign policy and national security matters, the Special Group is charged with the responsibility for preparing plans to prevent or defeat sulwersive insurgency in specific areas of the world. It also establishes broad policy guidance, integrates all programs for dealing with subversive insurgency, and ensures the best use of all available resources in a united effort."

In testimony before the House Committee on Foreign Affairs on November 18, 1963, Assistant Secretary of 
State Martin shed light on another procedure that, for Latin America, may well have taken up some of the slack resulting from the abolition of the OCB ${ }^{6} \mathrm{He}$ told of a number of United States governmental agencies that were assisting the governments of Latin America in dealing with the "insidious threat" of Communist subversion and in strengthening their internal security capabilities. The procedure called for an informal organization, the Latin American Policy Committee, which comprises senior officials of all agencies concerned. In its weekly meetings with $\mathrm{Mr}$. Martin, agreements on future programs were reached and, if a higher level decision was needed, issues were submitted to higher authority.

There is no mention in Mr. Martin's testimony of the relationship that eventually might develop between the Latin American Policy Committee and the Special Group, although each has the stated purposes of strengthening internal security capabilities and co-ordination. It may be presumed that Mr. Martin's committee could go to the Special Group for additional help in implementing policy decisions when help was needed. It is highly probable that, in view of the membership of the Special Group, it could and would pass on guidance and instructions to Mr. Martin, who could then use his own committee to see that decisions were carried out at the working level. Such implementing functions and follow up of high level policy decisions had been among the chief duties of the now defunct Operations Co-ordination Board. This is but another example of the function remaining even though the machinery had been abolished. It hardly seems conceivable that there should be 
conflict between the Special Group and this committee because of the prestigious personnel on the former. There might, however, be room for a certain amount of overlapping and duplication of effort.

Inasmuch as the meetings of the Special Group are reported in 1965 to be less frequent than the earlier practice of weekly sessions, it must be left to the individual employees in the departments of State and Defense and other agencies in Washington to perform those co-ordinating functions that might occur to them to be necessary or expedient.

Although it may be surmised that the counterinsurgency functions performed by the Special Group, from time to time, include attention to, and decisions bearing upon, military civic action, there is but slight official or published evidence upon which to support the supposition. It has been reported that when the former Director of the UsIA, Mr. Rowan, attended a session of the Special Group, he expressed an active interest in the military civic-action topic under discussion and indicated a desire that his agency perform a more vigorous role in advocating civic action and in publicizing its results. This meeting may well have had excellent results insofar as governmental publicity regarding civic action is concerned, but it is not a substitute for an interagency committee or board in continuous session whose normal duties would be to supervise and control and co-ordinate all aspects of the program.

In both the State and Defense departments, co-ordinating responsibilities have been laid out and personnel appointed to fulfil them. During 1961, both the President and the secretary of state spoke to the higher 


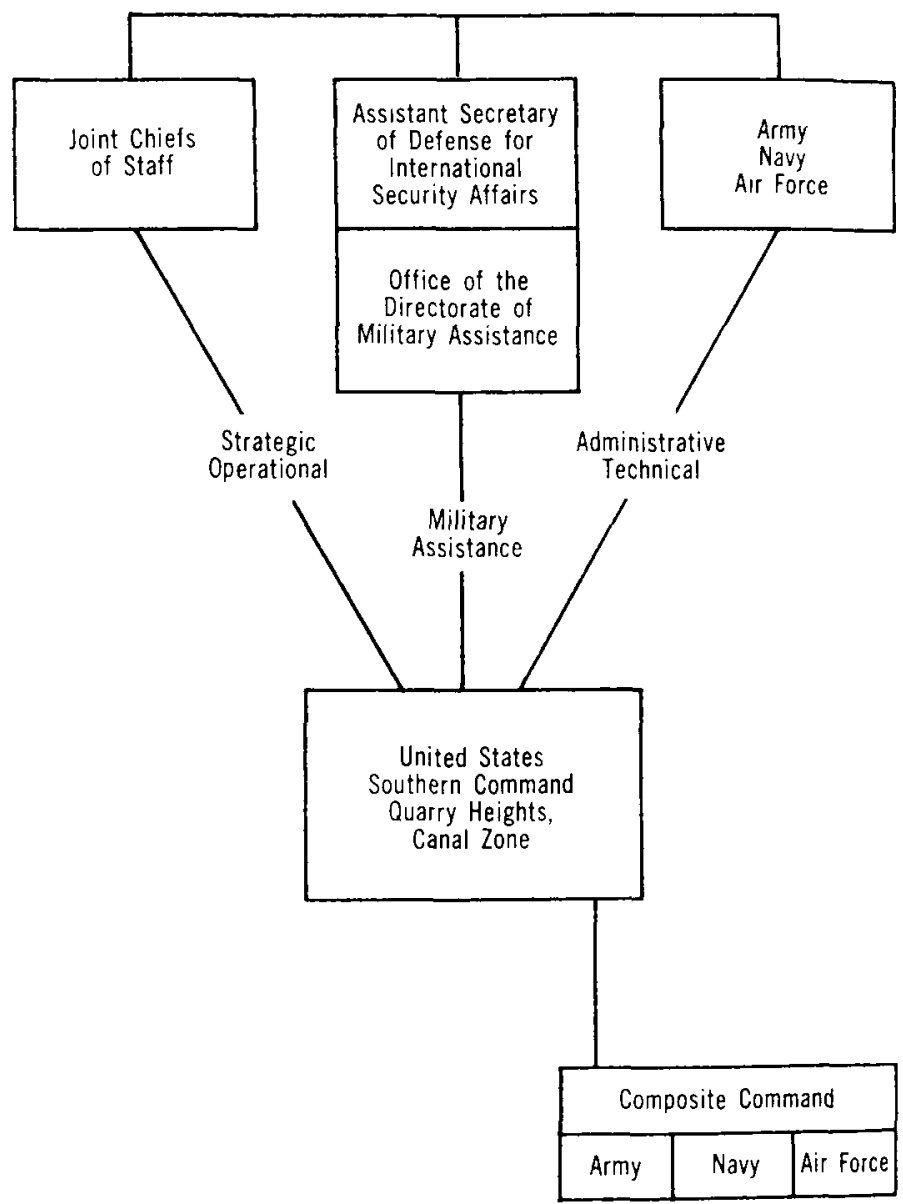

FIG. 2.-Composition and organization of the Office of the Secretary of Defense. (Civil Affars School, Ft. Gordon, Ga. 1964.) 
echelons of officers within the Department of State on the need for more speed in reaching recommendations and decisions on foreign-policy matters. In the course of such remarks to that audience as early as February 20, 1961, Secretary Rusk reiterated what President Kennedy had stated publicly the day before-that the assistant secretaries of state would be expected to carry an increased burden of active formulation and co-ordination of foreign policy.

The State Department's deputy assistant secretary of politico-military affairs $(\mathrm{G} / \mathrm{PM})$ is charged with providing guidance, co-ordination, and liaison with the Department of Defense and the military services on politico-military matters and relationships. $\mathrm{He}$ is also charged with assisting senior officers of the Department in their relationships with senior officers of the Department of Defense, the Joint Chiefs of Staff, and the military services. It is conceivable that the Deputy Assistant Secretary's Office could reduce, in a limited degree, the need for formal interdepartmental machinery, that is, for differences between state and defense on policy interpretation, implementation, and priorities. But this would not be the case with the other agencies and departments that might be deeply involved, such as the departments of Agriculture and Treasury or the Bureau of the Budget.

$\mathrm{G} / \mathrm{PM}$ is a small unit directly subordinate to the Office of the Deputy Undersecretary of State for Political affairs, ${ }^{\top}$ which provides a central point of focus and co-ordination on military matters for all geographic bureaus of the department-several of which already have their own political-military staffs. This unit was fashioned to provide both the Defense and State depart- 
ments' personnel with a common and obvious point of contact. One of the chief activities of $G / P M$ has been to strengthen national security by both planning and operating in this field. However, the co-ordination of economic and military assistance on behalf of the secretary of state is a function delegated to the Administrator of AID and his program co-ordination staff. In the language of the $U$.S. Government Organization Manual, 1962-63, in addition to direction of foreign assistance programs, "The Administrator reports directly to the Secretary of State and the President and is charged with central direction and responsibility for the economic assistance program and coordination of the military and economic assistance programs." There is, therefore, an obvious overlap with some of the work of $G / P M$.

Also within the purview of the $\mathrm{G} / \mathrm{PM}$ is the support and supervision of the political advisers, of which there are seven career Foreign Service officers assigned to United States military commands including United States Southern Command (us so com) at Quarry Heights, Panama Canal Zone. One Foreign Service offcer from $G$. $P M$ is assigned on a full-time basis to be adviser to the commander of the Special Warfare Center at Fort Bragg, North Carolina. The G/PM also deals with the officer exchange program (inaugurated in the Eisenhower administration) between State and Defense departments. By the end of 1965, approximately fifty officers from each department have filled a two year assignment in a comparable position at an appropriate level in the other Department. Another step in policy and training co-ordination is the assignment of State Department faculty advisers to the National, Navy, Army, and Air Force war colleges and to the Inter-American 
Defense College, the Industrial College of the Armed Forces, the Armed Forces Staff College, and the Air Force and Naval academies.

In an effort to achieve closer co-ordination, nearly all of the State Department's and AID's political and economic activities concerning Latin America, including those relating to the Alliance for Progress, were combined by then Assistant Secretary of State Mann, in 1964. As a consequence, there is an immediacy and proximity of State and AID administration in Latin American affairs that is not visible in the other geographic areas. This somewhat reduces the necessity for an additional co-ordinating body or person. But within the combined State/AID Bureau of Inter-American Affairs, there are to be found offices including (a) the United States Representative to the Inter-American Economic and Social Council and (b) the Office of Regional Political Affairs, which centralizes the bureau's relationships with the Pentagon. Moreover, there still remain as integral parts of the staff of AID a Military Assistance Division and a Public Safety Division. These two have not been combined with State's Latin American Bureau and continue to perform duties related to military assistance and local police projects in Latin America. Through these different channels, different aspects of counterinsurgency and the military civicaction program in Latin America flow.

In response to a congressman's questions, General Andrew O'Meara, then commander in chief of the United States Southern Command, stated in 1964 that

civic action is primarily coordinated with the AID program and very closely coordinated. In some areas the 
Peace Corps people are in a position to enter into some of the civic action in which we engage. Generally, they are on a more dispersed type of operation where they don't fit too closely to a road building or a school-building program or something of that sort. As far as the coordination with AID is concerned, in the last year or 18 months we have made very great progress on that. It is in a very satisfactory state right now. When we first started about $2 \frac{1}{2}$ years ago, some of the AID administrators didn't think this was a very good way to spend AID money, not as good as big dams, and so on. All that has gone by the board. The ambassadors are pushing it vigorously and the coordination is really the best and some of our best supporters for civic action are AID directors. $^{8}$

An additional lever of co-ordination in the field is the availability to the ambassador of a $\$ 50,000$ per annum "impact fund." If a worthwhile project of immediate significance comes up for which there is no AID program or if there is no other source available-this covers the time element for quick and emergency authorizationor if there is a pivotal element missing to complete the project, the impact fund can be drawn upon. This can also apply to existing and on-going programs. There is a separate $\$ 25,000$ emergency disaster fund on which the ambassadors may draw. When and where there is obstruction or lack of co-ordination, the ambassador can in some instances resolve the impasse by use of this fiscal authority, where or if other measures are ineffective. As a minimum he can give fresh impetus to a lagging civic-action program if he thinks it necessary or desirable to do so.

In addition to the creation within the State Department of the G/PM, other attempts to obtain a continu- 
Liaison

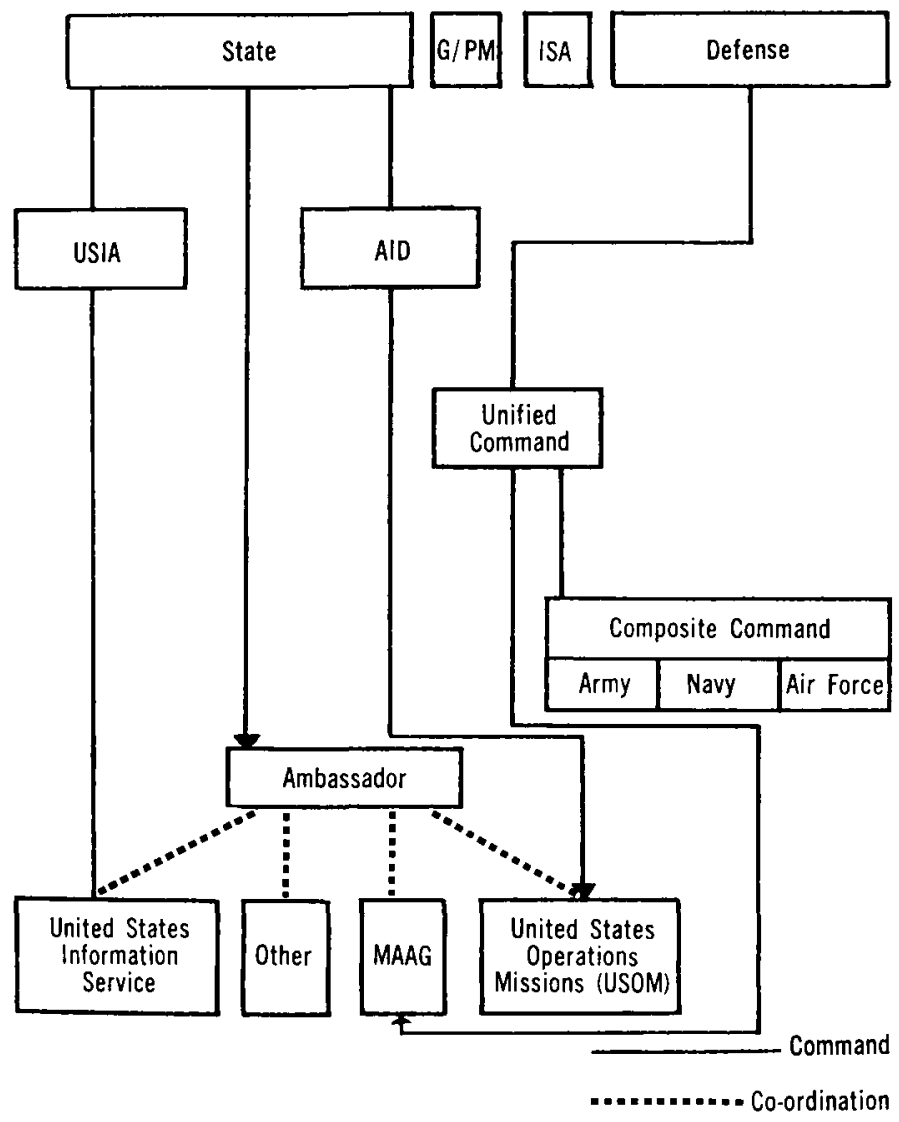

FIG. 3.-Field administration of military assistance. (Civil Affairs School, Ft. Gordon, Ga., 1964.) 
ing co-ordination and implementation of policy, both in Washington and in the posts abroad, have been initiated by the Department of State. One of these measures was introduced by Secretary of State Herter and Secretary of Defense Gates in setting in motion a plan for an exchange of outstanding civilian and key military personnel for selected positions in each department. Counterinsurgency and civic-action programs are, of course, but one small fraction of the total subjects and positions covered by this exchange.

One problem, illustrating the need that either a single individual or a continuous interagency committee or board be held responsible for civic action, is the question of funding. As it is, there is a somewhat ambiguous arrangement between the Department of Defense and AID, whereby the former finances those expenditures for military civic action in Latin America that can be styled as equipment and maintenance in support of military and paramilitary forces and for related training. AID has the financial responsibility for expenditures styled expendable soft goods, such as school materials, medical supplies, surplus food supplies (Public Law 480), as well as timber, cement, steel roofing, and other construction materials. The quest for financial support can be a key factor in determining the kinds of projects to be undertaken. Accordingly there are likely to be disagreements between departments. The fitting of projects into the national development plans, the priority among projects, the timing, and the amounts of United States financing, usually receives agreement within a Country Team. But final approval or disapproval may reveal an unbecoming scramble for authority and for 
policy implementation. Higher echelons may also dispute whether the direction should be toward nation building, economic development, or improving the image of the indigenous military. The result may be an interagency hassle over budgeting. Officers interviewed by the authors intimated that there are occasional lacunae between AID and MAP in planning and funding. There is also some lack of follow-up or maintenance of projects once they are started or completed. There is no regular, single Washington headquarters or office to manage, to co-ordinate, to supervise, or to support civic action, except the Special Group mentioned before, which meets at intervals and is not in continuous session.

Press reports in mid-1965 more than hinted at a lack of co-ordination between the departments of State and Defense in one area of counterinsurgency and civic action, i.e., research. Page one headline treatment reported that research questionnaires to members of the Chilean Armed Forces, and consultations with professors were conducted in Chile by the Special Operations Research Office in Washington, on behalf of the United States Army. Chile's "internal war potential and effects of government action" were under examination. The reports added that on December 17, 1964, an army "task statement on Camelot" referred to the project as being concerned with "equipping and training indigenous forces for an internal security mission, civic action, psychological warfare or other counterinsurgency action. ..." Apparently Ambassador Dungan in Santiago protested the study's being undertaken without his knowledge. The news account added that in April, 1965, Lieutenant General W. W. Dick, Jr., seeking $\$ 1.5$ billion for 
the army's research and development budget for 1966, replied to Congressman Lipscomb's inquiry as to comparable research by the State Department that "I am not familiar with what they may have." The State Department budget request for both intelligence and research was for $\$ 4,200,000 .^{9}$

Assuming that if even slight supervision on an interagency basis is performed by the Special Group, there is still to be taken into account the possibilities expressed by Mr. Charles Thayer in his volume Guerrilla:

Since the majority of its members are civilian political figures, the Special Group as presently constituted effectively assures that political aims remain dominant over temporary or purely military objectives [but] it has many of the earmarks and disadvantages of other ad hoc solutions. As an informal group meeting once a week, it owes its effectiveness largely if not exclusively to the dynamic personalities and prestige of its individual members. With no permanent constitutional existence, it is at the mercy of whatever influences are currently dominant in Washington. Thus with a change of administration it might well disappear without a ripple from the scene, leaving the old concepts to guide the formulation of policy. Even more likely if less energetic and able persons were to replace present members, it would in all probability join the long rank of other ad hoc committees which like ghosts haunt the government's corridors and payrolls. ${ }^{10}$

The revamping of United States governmental organizations for dealing with the internal security of nonCommunist countries was accompanied by another important development. The evolution of United States hemispheric security doctrine from that of defense against external armed attack to that of defense against 
subversion had been accompanied by increasing doubts concerning the utility of the inter-American security system. A series of special meetings to deal with cases of an alleged Communist threat had convinced the United States that existing inter-American security machinery was a weak reed on which to lean. One of the developments growing out of this situation was a realization of the importance of bilateral arrangement in dealing with problems of internal security. Accordingly, notes were exchanged with a number of governments regarding their commitment to employ United States-furnished armaments for internal defense purposes. The list of these exchanges of notes is found in Table 1 , in Chapter II. The text of the notes may be found in Appendix G.

\section{Internal Defense Plans}

Another step in emphasizing bilateral arrangements for hemispheric security was the preparation of "Internal Defense Plans" for selected Latin American countries. These plans are apparently unilateral as far as preparation is concerned and can be called bilateral only in the sense that they are the basis for recommendations to, and negotiations with, the country concerned. An Internal Defense Plan to meet the requirements set out by the Department of State would contain a political and economic appraisal of the host country, the adoption of measures to strengthen vulnerable points of the local society, the development of political policies and military capabilities to maintain internal security, and the mobilization of local governmental resources to support those policies and capabilities. ${ }^{11}$ (See Appendix B.) 
The chief of the United States Diplomatic Mission (the ambassador or his deputy) as head of the United States Country Team is charged with the development of the Internal Defense Plan. In addition, the Country Team comprises the chief representatives of the United States agencies on the staff of an embassy abroad. It would be expected that the AID man on the Country Team would recommend economic and financial programs; the USIA representative, the psychological operations; the intelligence man (CIA or otherwise), appropriate measures in his field of competence; and the military representative, the equipment, personnel, and training that would be required. The embassy would be responsible for over-all evaluation and co-ordination and for enlisting the co-operation of the host government. The Internal Defense Plan, once drafted by the Country Team and forwarded to Washington with the approval of the ambassador, might very well be the subject of modifications and additions by government agencies in Washington. It would be normal, for example, for such a document to be submitted to the chairman of the Department of State's Planning Council.

\section{Difficulties of Co.ordination}

In each of the United States embassies, there are military attachés. In some instances, the attachés office is composed of officers and enlisted men of the army, navy, and air force. Additionally, in most of the Latin Imerican countries, there are either military missions or military assistance advisory groups (MAAG's). The function of the missions and MAAG is normally specificd 
in government-to-government agreements, placing the mission and NAAc; advisers in the position of advising and counseling the host military establishment. Thus they are not carried in the diplomatic lists or considered to be staff members of the United States Embassy. The MAAG's have a particular responsibility for advising and training on the use of military equipment sent to the host government. On occasion, specified duties involving adrice on military hospital construction and administration, small arms instruction, and administration and teaching in the military schools are undertaken by MAAc; personnel.

This is quite distinct from the functions of the attachés office, which can be summarized as falling generally under two headings: the representation function and the intelligence gathering function. Operating as they do in a different relationship to the United States embassy and being responsible as they are to different headquarters in the Pentagon, these distinct military advisers have, on occasion caused ripples of disagreement in the field. An attaché seeking information may be displeased at the unwillingness of United States MaAG officers who refuse to divulge information pertaining tw local military developments. An ambassador, seeking technical military advice in order to determine what his recommendation to 1 ashington should be regarding the kind and amount of military assistance to the host government might receive contradictory advice from an irtillery man in the attachés office, as compared with an engineering officer in a MAAG. However, the opportunities for divergence should not hide the opportunities that exist for collaboration and co-ordination-oppor- 
tunities which are normally utilized and which a tactful ambassador can develop and exploit to the benefit both of the United States and of the host government.

One of the principles emphasized at the United States training institutions is that military civic action should have local and indigenous initiative in the choice of tasks. Nonetheless, it is quite likely that embassy scrutiny and judgment is exercised at various stages before a country program is accepted. This scrutiny may occur in conversations between the ambassador and a MAAG officer working on civic-action assignments. The embassy may also consult with the military attaché (who may have an opinion at considerable variance with the MAAG officers). Discussion of such topics with appropriate host government officials and with the local AID representatives may shed additional light on the advisability of adopting a specific course of action, as well as assuring that local collaboration will be forthcoming. Under the existing division of responsibility for civic-action decisions, issues such as comparative priority of projects, funding, and timing may be pivotal factors in Country Team discussions and in the ultimate recommendations made within the embassy. The recommendations forwarded to Washington may be modified at an intermediate level by the United States Southern Command to make them compatible with the hemispheric-wide plans and operational capabilities. Finally, embassy recommendations to the State Department and AID headquarters in Washington are taken into account by the decision-makers simultaneously with the views of MAAG forwarded by the Southern Command to the assistant secretary of defense for international security affairs 


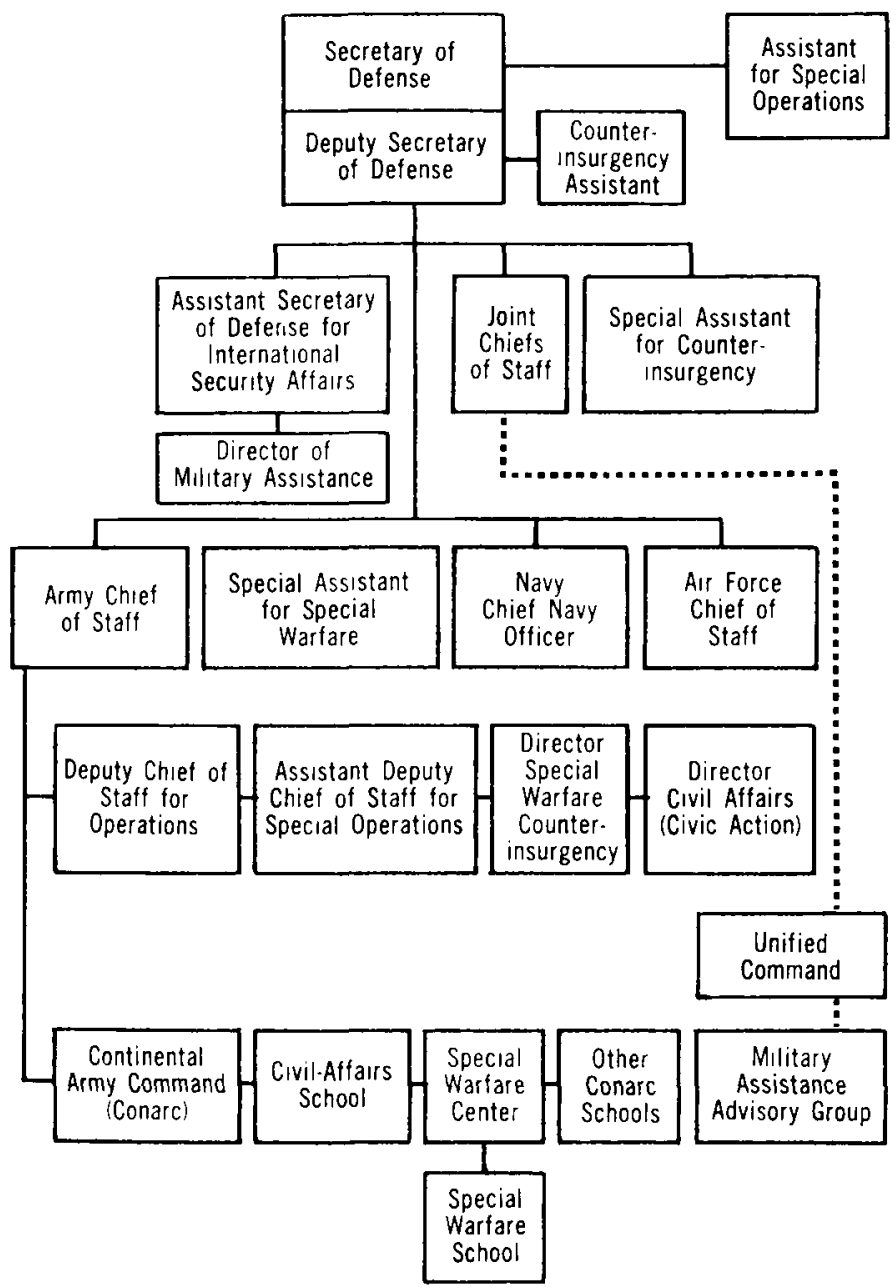

FIG. 4.-United States Department of Defense organizations for counterinsurgency and covic action. (Special Warfare and Civil Affairs Missıon, U. S. Continental Army. Contınental Command, Fort Monroe, Va., 1965.) 
AsD/ISA. Within the Pentagon, ISA forwards the plans to the Joint Chiefs of Staff who, in turn, send to the respective service chiefs those sections of interest to them. It is clear that there is the necessity for clearances and co-ordination at different levels.

The totality of co-ordination efforts also involves many levels of high officials in the State Department and its Policy Planning Council. Also participating are the Geographic Assistant Secretary's Office (and the regional AID director), the Office of Deputy Undersecretary for Political Affairs, and the deputy assistant secretary of state for political/military affairs (as shown in Figure 3) for co-ordination and liaison with the Department of Defense.

But, at a much earlier stage, the inputs for this decision may have proved to be determining for the professional disciplines within the MAAG's-i.e., sanitary engineers, ariation or armor specialists, and transportation or medical officers will tend inevitably to orient the local program recommendations along the lines of their own specialties. Is this a proper test to determine what kinds of civic action should be proposed? What scientific, statistical, or objective criteria are applied to choose projects? The same questions are relevant to the makeup of the MTT"s (mobile training teams) sent by the Pentagon to a Latin American country. What scientific, objective criteria are used in selecting the members of the MTT? If educators or transportation men are put on the MTT, can we expect anything but educational or transportation projects to be studied and recommended? This puts AID and the embassies in the field at a considerable handicap in expressing their views of 
what the best choice of civic-action projects should be. Stated another way, this means that, in effect, decisionmaking is accomplished at a much earlier stage than is generally realized and by individuals unknown and perhaps not responsible for United States relations with the host country. It is decision-making by subordinate members of the United States military establishment.

Having reviewed the organization and co-ordination within the United States government for counterinsurgency and civic action, let us examine the corresponding organization in the Latin American countries. Are there differences between planning in Washington and practical operations in the field?

\section{III}

\section{Administration in Latin America}

Under the direction of the United States ambassador abroad, Country Teams have the responsibility of working with their opposite numbers within the host government for planning, training, operating, and publicizing civic-action projects. Difficult as it may be in some circumstances for the United States Country Team to obtain total harmony and the continuing co-ordination of all aspects of the civic-action program, an additional hurdle must be overcome in the liaison with different agencies and at different levels of the host government. Much depends on the good will and acceptance of active leadership by the chief of state and his military officials. Even the acceptance of the concept and promise of 
firm support by these persons requires a co-ordination and follow-up function in order to achieve results.

Although most of the activities now called civic action have been carried on for a long time, they were not thought of as "a program" and no reason for co-ordination was apparent. In some cases they were engaged in as a normal or traditional duty of the armed forces; in other cases, it was on an ad hoc basis at the request of another government agency. These permutations are still a prominent feature of administration and implementation of what is now called civic action. Some countries have recently set up special organizations for co-ordination and implementation of civic action. In many cases. however, they either remain largely on paper or, in any event, accomplish little administration and co-ordination. The operational procedures laid down for these tasks vary substantially from country to country. Some have created a co-ordinating agency on the ministerial level, making it directly responsible for the planning and direction of military civic action. Others maintain special military units devoted exclusively to carrying out civicaction tasks. The remainder works within the regular military organization itself to accomplish these activities. The armed forces of some countries act on their own initiative, independent of civil authority and employing their own funds and manpower. In others, civic action is accomplished at the request of civilian agencies with the armed forces supplying technical direction, personnel, materials, and equipment. Although it would be impossible to select "representative" examples from a widely divergent continent, the following will show some of the varieties of administration. 
Colombia.-A presidential decree in November, 1962, created the National Committee on Military Civic Action and gave it the mission of co-ordinating civic-action activities throughout the entire nation. It includes the ministers of government, war, agriculture, public health, national education, and public works. This committee may also include official, semi-official, and private entities, as well as private individuals who wish to forward its purpose. The minister of war serves as an executive secretary for the committee.

Chile.-The government of Chile has relied on a variety of ad hoc measures for administration and implementation. A decree of March 26, 1960, created the Military Work Corps as an independent agency under the commander in chief of the army. Any entity of the National and Municipal Public Administrations (official, semiofficial, or autonomous) is empowered to carry out works in conjunction with the Military Works Corps, the cost being charged against funds that are budgeted to the respective entity. By another executive decree, the army factory and machine shop, and the navy shipyard and machine shop, operate with the Corporation for Production Development, subject to a supervisory council. Directed by military officers, both of the military entities engage in contract work for civilian users. By Executive Decree of November 10, 1942, the army and the Corporation for Production Development were empowered to carry out jointly a program of training conscripts in the operation of tractors. By another decree of December 19 , 1958, the National Defense Ministry and the Ministry of Agriculture were made responsible for a forest firefighting brigade. The Chilean Air Force collaborates with 
the Ministry of Public Works, the Institute for Geological Research, and the National Electric Power Agency in conducting an aerial photographic service.

Venezuela.-In Venezuela, forest fire-fighting, reforestation, and the development of nurseries are undertaken by collaboration. The Ministry of Defense, the commanders of the armed forces, and the Armed Forces of Co-operation ${ }^{12}$ join with the following civilian agencies: Ministry of Agriculture and Livestock, the National Universities, Ministry of Public Works, and the Federation of Air Clubs. Plans are administered by the Joint Military Staff through the respective armed services. The Office of the Commander of the Army has responsibility for operation of agriculture and livestock schools to train recruits in modern techniques. The Ministry of Education establishes Popular Culture Centers in all military installations for literacy training and additional collective centers for literacy are operated by military personnel in various areas without schools. The Engineering Service of the Ministry of Defense co-operates with the Ministry of Public Works in highway and airfield construction in the remote provinces. The Engineering Service directs and executes the construction, the Department of Public Works provides the finances and machinery.

El Salvador.-The national organization for civic action in this country has a director general in the Ministry of Defense, a National Central Committee, a public relations unit, and regional and local committees. The National Central Committee members are the ministers of education, interior, agriculture, health, public works, and defense. The director and the Central Committee 
prepare annual civic-action programs. Local military commanders perpare and submit detailed civic-action operations plans to the Ministry of Defense in accordance with, and supplementary to, the national plan. If locally available resources are inadequate, requests for assistance are to be submitted to the higher level committee for consideration. A monthly report on civicaction accomplishments is required to be forwarded to the Ministry of Defense and to the chief of the general staff of the armed forces. The Salvadorian 1965 CivicAction Plan has a logical and careful time schedule of operations reflecting this tight administrative hierarchy. The plan, largely conducted by the army's engineers, gives priority to building repairs; rural-road, sportsfield, and bridge construction; and clearing land for farming. The plan spells out the kind and amount of supplies and equipment that local military commands are authorized to use for civic action with a specified time when heavy equipment will be used in a specific zone. Plans and reports are required for this, as well as for the other detailed arrangements for literacy, health, and public welfare programs. Dates, places, and amounts of supplies are specified. Altogether, it is a well-knit twentythree page operation plan in four main fields. Public relations elements are stressed throughout.

Bolivia.-For a number of reasons the arrangements developed in Bolivia for the administration of civic action are of particular interest. In 1952, the advent of the revolutionary regime meant the eclipse of the old army, and after a slow buildup, during the past several years, the new armed forces were given increasingly important roles in economic development of the country. 
There was wide geographic distribution of the armedforces activities and a great range also in the nature of the work they undertook, including road-building, community devclopment, colonization, agriculture, education, potable water, and river improvement. In 1955, a colonization division of the armed forces was created that built roads, cleared lands for settlement, planted and marketed crops. Men who pioneered by working in this division were given improved farm land. Substantial United States economic aid and MAP assistance was given to Bolivia on a per capita basis (this was the largest amount of help for any Latin American country). An unusual aspect was that United States assistance came entirely from AID and none from MAP because of the historical origins of the program. Through AID, there were made available counterpart funds derived from the sale of United States agricultural surpluses. ${ }^{13}$ Thus the Country Team at La Paz was able more directly and quickly to obtain funds for projects that were agreed upon locally. It has also been reported that the local AID officials, enthusiastic about the civic-action program, gave an unusual amount of time and influence to further its progress, and received active co-operation from the embassy and the MAAG chief. Furthermore, Air Force General Barrientos, who assumed the presidency after the overthrow of Paz Estensorro in November, 1964, was a strong advocate of civic action, both before and since assuming the presidency.

Administrative changes in 196,5 were notable. In January, 1965, the Bolivians assumed primary responsibility for project-planning and distribution of funds through the National Office for the Promotion of Human Re- 
sources under the auspices of the minister of economy. All governmental ministries (i.e., Defense, Health, Public Works, etc.), which have a capacity or need for civic action, send representatives to this office during the planning sessions to recommend projects. AID and United States military technicians and advisers support their counterparts in this office by advising and assisting them in the preparation of a national civic-action program. Meanwhile, the armed forces have been reorganized to create nine regional civic-action staff sections with responsibility to foster, implement, manage, and report upon the progress of civic-action projects in their respective regions. The nine newly organized regional offices are focal points for civic action in what has been previously a very decentralized operation. Similarly, several community-development centers are to be established for the training of community-development, village-level workers and for distribution of such items as water pumps, building materials, and Food for Peace supplies to stimulate self-help civic action and community development programs.

The Barrientos government made up of an all-military cabinet, received United States recognition a month after taking power. A military officer, Colonel Julio Sanjines Goitia, an engineering officer, was named Bolivian ambassador to the United States in 1965. Obviously having absorbed some of the ideas of United States civic-action planning, Colonel Sanjines issued in 1964, a forty page pamphlet, in English, entitled Civic Action: Role of the Armed Forces in the Social and Economical Development of a Country. The pamphlet's prologue was signed by Colonel Truman F Cook, then chief of the United 
States Military Mission to Bolivia. Citing the official United States Joint Chiefs of Staff definition of "Military Civic Action," Colonel Sanjines" pamphlet goes into the doctrinal and organizational aspects of civic action and submits a model plan of organization-with charts and diagrams. He contemplates the creation of a fifth department in the Office of the Commander in Chief of the Armed Forces. This Department would prepare and co-ordinate an Armed Forces Plan to pursue economic and social objectives, including agrarian reform, directed by a technical section and an economic section. Both immediate impact programs and long-range programs are fully listed. The fifth department would have planning and co-ordinating and controlling duties with the actual execution of projects being left to the three military services. If the plan should become a part of the national development plan, the resources for its execution would come from the national budget and foreign loans and credits, otherwise its funds would derive from the armed forces resources. (The pamphlet, issued at La Paz, bears the imprint of AID's Audio-Visual Center.)

Argentina.-The Argentine armed forces have a long history of civic action dating back to the origins of the republic. There are no military units that devote their full time to civic action. The air force is reported to have no formal plan for civic action in the future. In such areas numerous small projects are undertaken, such as rescue and disaster relief; literacy education; medical services; and road, bridge, telegraph line, and school construction. ${ }^{14}$ Transportation to remote areas in the south, both of goods and of people, is a typical navy service, as 
is weather forecasting. The Argentine program has not received assistance from AID or other United States civilian agencies but has benefited from MAP equipment for construction purposes. United States Army mission officers helped to establish a course of instruction in civic action in the military schools and arranged for Argentine officers to attend the Civil Affairs School at Fort Gordon. The compilations of the United States Southern Command indicated a heavy emphasis on public relations and mentions sports events, band concerts, and similar activities. Military publications pay serious attention to civic-action projects and training. ${ }^{15}$

Mexico.-While the Mexican armed forces conduct many projects of a civic-action nature, there is no government- or defense secretariat-directed civic-action program per se. It is a program undertaken when needed and as needed by the thirty-four zone commanders in conjunction with the state governors. In the absence of a central program, the military at all levels are encouraged in such projects. Only three, apparently, have any central co-ordination at the secretary of defense level. These are: (1) Civil education: the armed services have built many 1-2 room school houses in rural areas; they also provided basic education instruction in areas where teachers are few. (2) Antideforestation and antipoppy/ marijuana patrols accomplished jointly by the army with naval air and air force elements. (3) Highway and polling-place surveillance during tourist seasons. ${ }^{16}$ Other actions of interest are school rehabilitation, reforestation, antimalaria campaigns, building of secondary roads, and disaster relief. All military schools in their curriculums have courses emphasizing the importance of civic action 
to internal security. They use many United States military texts and instruction materials. However, Mexico does not accept any grant assistance from the United States. Even offers of medical supplies and athletic equipment have been politely refused. The reason that the Southern Command compilations of civic-action projects do not give any data about Mexico is the absence of a MAP for that country. It should not be inferred that there is no civic-action program because of the lack of publicity in the United States. The contrary is the case; following the revolution of 1910 and its aftermath, Secretary of War Joaquín Amaro adopted a strong policy of putting the recruits to work at road-building and public works. Under Presidents Obregón, Calles Cárdenas, and Camacho these functions were continued and expanded, especially in educational matters.

Honduras.-An editorial in a journal, ${ }^{17}$ devoted entirely to military civic action, stated that Article 316 of the Honduras Constitution provides for the collaboration of the armed forces with other governmental agencies in the fields of agriculture, education, communications, colonization, and literacy..$^{18} \mathrm{~A}$ director of civic action, with the rank of major and a member of the staff of the Ministry of Defense and Public Security, directs and centralizes control over the entire program, including air force projects. Some of the many diverse projects included provision of medical services and sanitary and drainage facilities, and the construction of roads, schools, public buildings, and furniture for schools. Significant attention is also given to public relations. A strong effort at co-ordination is made by the Honduran government with the help of the chief of the armed forces, 
Brigadier General Oswaldo López Allennaro. The program could be considered to combine as a purpose and intended result the strengthening and continuance of the military role in the country. Repeatedly, articles in the Honduran publication Revista Militar stress the socialeconomic purposes of the military government's work to assist the public through several kinds of civic action. Coincidental with this, and equally pertinent in the issues of Revista Militar, are descriptions of the activities of the United States Military Mission to Honduras. ${ }^{10}$ This review published several articles on civic action, developing the idea of bringing the public closer to the government and to the army in order to erect a successful barrier against guerrillas and insurgents.

Guatemala.-In November, 1960, a Department of the army civic-action team was sent to Guatemala at the request of President Ydígoras, who soon created a civicaction section in the Ministry of Defense staffed by Guatemalan civic-action officers trained by the Country Team. This team visited military installations in, and traveled extensively throughout, each military zone. A civic-action plan that was developed for the country included the selection of a number of low-cost projects for the military units to undertake in each zone. Among the projects were irrigation, dispensary services, road improvements, school construction, water purification, sanitation measures, and communication improvements. The recommendations of the team were accepted by the President and ordered into effect. The President also requested the assignment to the Army Mission in Guatemala of a permanent, full-time civic-action officer to guide and direct the activity. Several months after the 
United States team's return, President Ydígoras, in his State of the Union Message to the Guatemalan Congress, declared: "There has now begun to infiltrate within the Army a new spirit of cooperation in favor of community development at the site of each military unit." ${ }^{20} \mathrm{Al}$ though civic-action-type activities have been undertaken by the Guatemalan Army for many years, the idea for implementing a program of civic action in Guatemala was stated to have been inspired by Resolution XLVII adopted by the Inter-American Defense Board in 1960. The text of the Resolution is given in Appendix D.

In 1961, and again in 1962, civic-action survey teams conducted examinations of the existing program and recommendations were submitted to the Guatemalan government that requested and received the assignment of a full-time civic-action adviser to the army. In April of 1963, the AID office in Guatemala appointed as civicaction co-ordinator a man previously the civic affairs officer at United States Southern Command. In order to further co-ordinate the AID/MAP support of civicaction projects, a Guatemalan civilian, previously employed by the Guatemalan Army as a civilian medical adviser to the civic-action program, was hired by CARE as business manager to administer the CARE Civic Action Co-operative Project. This established close co-ordination between these agencies to insure maximum utilization of equipment, funds, and labor.

The organization for the conduct of civic action by the Guatemalan armed forces is unique in that the United States civic-action officer acts purely as an adviser; the Guatemalan armed forces conduct the entire program. Projects are developed in community 
relations councils organized in each of the military zones or the areas adjacent to the major military installations. These councils, consisting of both military and civilian members, meet each month to discuss and propose projects that can be mutually supported and can be of great benefit to the community. One of the military members of this council is a Guatemalan officer assigned as civic-action project officer for this particular area. Present at the meeting may be the United States civicaction adviser, AID civic-action co-ordinator, and a CARE representative. If the project developed does not require United States funds or equipment, then the military and civilian elements of the local community proceed with the plans. When additional funds or equipment is needed, the project is submitted to the Guatemalan general staff civic-action section for review. This section then may co-ordinate it with the various ministerial offices concerned. If funds or equipment is not locally available, the project is then presented to the United States civic-action adviser for review and co-ordination with MAP, AID, CARE, and the embassy, leading to Country Team approval. Thence they are forwarded for financing support by AID or MAP or possibly both. When the equipment or supplies arrive, they are turned over to the local unit working on the task. ${ }^{21}$ "Credit for the affirmative response from Guatemala can be linked clearly with the personalities and past experiences of two men-the Guatemalan president and American Ambassador [Ambassador Muccio, who had observed civic action in Korea]. The then president, Migel Ydígoras Fuentes, had been an army general. He also at one time had been the Director General of Roads.",22 
The administration of civic action within the Guatemalan Government takes the form of a special section of the army general Staff entitled "Public Relations, History, Cultural and Civic Action." In each brigade, in military zone headquarters, and in the air force and navy elements of the armed forces, there is a Civic Action Projects Office. The Community Relations Council organized in the local communities must also be considered to be a part of the organizational structure. Local conferences are held annually to brief and to guide the project officers. Four Guatemalan officers trained in United States schools in civic action were employed in various phases of civic action until late in 1964, when three of them were reassigned to other duties. The United States civic-action adviser is in daily contact with his Guatemalan counterpart AID, CARE, and the appropriate ministries of the government. The use of community relations councils has been held to be of great benefit in establishing an active program and in improving military-community relations. Many small but important projects are completed with local military and civilian labor, equipment, and funds, thus affording both the local military commander and community leaders a pride of accomplishment and a desire to do more selfimprovement. Different communities place different priorities on the things that they want and are willing to work for.

The frequent articles on the inauguration or completion of civic-action projects normally feature the presence and the words of the military head of government. An example is the February, 1964, issue of the Guatemalan publication Ejército, in which President Enrique Peralta 
opened a number of roads, schools, and a saw mill in an undeveloped area of the country in the province of Petén. The president was accompanied by a number of cabinet members and the United States ambassador. Other issues of Ejército in 1964 report conferences in the Ministry of Defense regarding the publicity campaign for civic action. One Guatemalan officer had just returned from attending the Information Training School conducted at Fort Slocum, New York. Probably as a consequence, each issue of the military magazine carried extensive articles and photographs of civic-action projects, as well as numerous reproductions of articles appearing in local newspapers. Bridge-, road-, and schoolbuilding, potable water wells, and medical clinics are the activities most frequent to be publicized. Reforestation, cattle-raising, veterinary services, and the printing and distribution of school books are also given attention, as well as school lunches, distribution of shoes for school children, and instances of disaster relief. The military press reports in detail on the organization and function of local civic-action committees.

\section{Unusual Aspects of Civic Action in Central America}

Compared with the countries south of Panama, the Central American countries' energetic and enthusiastic adoption of military civic action is notably different, as has been demonstrated. The experienced observer of Latin America can detect in the speeches of its leaders and the publications issued by its defense departments the ideas and arguments advanced by United States spokesmen for civic action. The same ideology and the 
same phrases are utilized. There is much publicity. $\mathrm{C}_{i}$ vilian and military officers of high rank co-ordinate and administer civic-action programs. By virtue of the intensity of attention and the great expense attendant upon the military's participation in these functions, an impression is created of an all-out effort and an allencompassing military establishment.

It is significant that the governments of Guatemala, Honduras, and Nicaragua are militarily oriented. In Honduras and Guatemala, connections with the United States Embassy and the United States military missions are close, frequent, and widely publicized. In Nicaragua, the military's administration of rural police, education, communications, transport, intelligence, and construction activities provides a concentration of control by the Somoza family in many facets of the country's life. A study of civic action as practiced in Nicaragua raises the question as to whether the result is a general encouragement to the government to intervene in economic matters. The reader may consider that this factor may have much wider application than just in Nicaragua.

Quite distinctive is the situation in Costa Rica where the Civil Guard, scarcely a professional military organization, performs police functions but has undertaken some projects of construction, engineering, education, and health measures similar to those considered to be civic action. If any of the Central American countries were lacking in ideas for organization of their counterinsurgency and civic action, a conference on that subject held at Fort Gulick, Canal Zone, in November, 1964, more than took care of any gaps. A half-dozen Latin American delegations attended. A monumental adminis- 
trative hierarchy was proposed at national, regional, and local levels. A national assembly representing all levels would meet twice a year to establish the guide lines and program for civic action. The execution of the plan would be in the hands of a Board of Directors consisting of spokesmen for each of the government ministries affected. A technical assistance council would consult and audit the projects, and a co-ordination committee would integrate the work of the government and private entities. There would be comparable organizations at the regional and local level. The flow of ideas and plans would be forwarded from the national to the local committees.

This plan would prohibit the naming of projects for individual military officers; only the armed forces should be mentioned as the sponsor. The funds for all of this should come from the National Defense Budget. The conclusions of the report prepared at the end of the meeting were of a somewhat similar and flamboyant nature:

Experiences derived from the successful accomplishments of civic action programs in countries such as the Philippines, Venezuela, Colombia, and others, make it possible to consider civic action as the most effective means of combatting insurgency and the expansionist plans of communism in the Latin American countries. These experiences show that civic action is the best weapon by which to gain public approval in our countries, obtaining the support of the populations, stability in legitimately established government and gaining the affection and respect of the people for the Armed Forces. ${ }^{23}$

The overstatement of objectives, coupled with unnecessarily complex and burdensome bureaucratic ma- 
chinery to manage what is at best but one aspect of the nation's counterinsurgency and defense policy, can be as injurious to successful results as is apathy or lack of planning at the other extreme. Several of the Central American programs suffer in this way. There is a likelihood that the expanding jurisdiction claimed for civic action may discourage private commercial enterprise. In these countries of limited resources, it may not be highly economic or efficient exploitation of those resources to permit them to pass into the hands of the military. The intimation that the programs are planned to help keep the existing military regimes in power yields other misgivings as to the political purpose for which so much was hoped at the time of the acceptance of the civic-action doctrine.

In 1962, a first Central American Conference on Civic Action was held in Guatemala City, and in December, 1963, a second conference was held in El Salvador. A third met in Teguicigalpa in 1964 and a fourth was scheduled for 1965. In each of these conferences, delegations were present from Honduras, Guatemala, El Salvador, Nicaragua, and Panama, but not from Costa Rica. ${ }^{24}$

\section{Top-Level Direction and Team Work}

It may be that the existence of an organizational structure can be taken as an index of a successful (or serious) attempt at civic action. Some close observers have remarked that a key prerequisite for successful civic action is the commitment by top echelons. This might be civilian or military. But we cannot assume that the existence of some formal organizational structure 
reflects the acceptance by the "top echelon" of a workable formula. In addition to top level support, there is in military civic action a special need for continuous team work-a quality for which Latin American administrators are not particularly noted.

By its very nature the execution of civic-action projects infringes upon the opportunities, responsibilities, and bureaucracies of various ministries such as Public Works, Communications, Agriculture, Education, Public Health, etc. Indeed, there is a double danger here in that follow-up maintenance of projects (also a less than perfectly fulfilled function in most Latin American countries) may very well obligate the other ministries after the military civic-action team has completed the construction. Thus, the turning over of a road, a school house, or a communication installation would require supplies, administration, upkeep, management, training and arranging of personnel, and budget demands on the regular ministry. This can, and does, place a strain on any interdepartmental relationship, in countries more devoted to the science of administrative practice than are the Latin Americans. The problem of efficient use of limited resources cannot be ignored. In countries where there are such shortages is the military the means by which the greatest economic benefit can be obtained?

At another level, the team-spirit requirement to obtain local support by citizens and officials in civic-action projects is elemental if one of the basic objectives of civic action is to be attained; that is, an improved public image of the central government and of the military. This is easier said than done. Skeptics abound in the villages and in the country. They are likely to think of 
a road project in terms of the enhanced property value for a local political boss and to suspect profiteering somehow or somewhere in connection with the arrival of expensive supplies or heavy equipment. They may be disappointed to learn that a new school will be used largely for the benefit of the army officers' children, or they may be made jealous by gossip of greater advantages accruing to another neighborhood.

A basic problem rarely discussed is the local citizens' reaction to the civic-action effort that is designed to benefit them. What and where are the means to reach the public? It is not likely that villagers or country folk will be much more than onlookers unless positive steps are taken to go further than merely to arouse their curiosity. The working together with the military on a project of benefit to their area will improve the public image of the military, which is one of the proclaimed objectives. But in order to accomplish this co-operation, public relations or educational programs may be found to be necessary to establish the need for, and the utility of, departures from traditional ways. (Usis can have a significant role in helping with the public relations aspect, and United States "Food for Peace" may be utilized to provide incentive for civilian co-operation.) This can be done if the people work on a project of their own rather than standing by and watching strange men in uniforms doing strange things. A performance with immediate impact will often provide the experience and encouragement for a later, more ambitious undertaking, responsive to the country's long-range economic needs. Herein lies an opportunity to put into effect the much discussed ideology, "We are in a struggle for men's minds 
and souls," with the much discussed co-ordination of all agencies, usia, Food for Peace, and United States Military and diplomatic personnel.

1. A United Press International news report, carried in the February 20, 1961, issue of the New York Times, under the heading "President Ends Top Policy Body," stated: "President Kennedy moved today to strengthen White House control over national security and foreign policy actions and assure that Federal agencies adhere to the policy of the White House in those fields.' Mr. Kennedy said he intends to maintain direct communications with the responsible agencies 'so that everyone will know what I have decided.' Much of the responsibility for the Board's work will be centered in the Secretary of State. 'This is part of the President's program for strengthening the responsibilities of individual Government Departments and insuring close White House liaison with them.' He said he expected senior officials who had served on the Board to keep close informal touch with each other on problems of common interest. Mr. Bromley Smith is to continue to work with $\mathrm{Mr}$. Bundy "in following up on White House decisions in the area of national security,' the President said. 'In their varied ways, we intend that the net result shall be a strengthening of the process by which our policies are effectively coordinated and carried out throughout the Executive Branch,' he explained."

In hearings before the House of Representatives Appropriations Committee in 1963, presumably referring to the Special Group, General Taylor stated that a completely new structure which might be called in effect, a Joint Chiefs of Staff of all agencies involved in counterinsurgency had not existed prior to January, 1962 (Subcommittee of House Appropriations Committee, Hcarings, Defensc Department Appropriations for 1964, Part 1, p. 484.) In testimony on February 13, 1963, in reply to Congressman Flood's questions, General Taylor said, "I find we have a completely new structure which never existed prior to January of last year. Regarding the high command, you might say we have a sort of JCS for the control of all agencies involved in counterinsurgency." Also see p. 321 of "National Security Seminar," Industrial College of the Armed Forces, Washington, D.C. 1964-65, section on counterinsurgency, pp. 309-23: "Special Group (Counterinsurgency) [consists of the] Undersecretary of State of Political 
Affairs, (Chairman) ; Attorney-General; Deputy Secretary of Defense; Director of CIA ; Chairman of JCS; Administrator of AID; Director USIA; White House representative."

2. Reported in a comprehensive article published in the Wall Street Journal, June 27, 1963. The article was clearly the result of conversations with Washington officials entirely familiar with the Special Group's activities. In a lecture by Colonel Bussey, "National and Defense Organization for Counterinsurgency," at the Army War College on June 19, 1962, p. 271 (Insurgeney and Counterinsurgency: An Anthology [Washington, D.C. . Industrial College of the Armed Forces, October, 1962]), it was stated that probably the most important function of the Special Group was to make Washington aware of the problems arising out of insurgent movements and to develop plans to prevent or to defeat these movements. The group also was responsible for establishing a policy and insuring unified and integrated action programs by the government agencies. He styled the Special Group as "the focal point within the government for policy and planning coordination in the field of Counterinsurgency." In the April 12, 1965, issue of U.S. News and World Report, it was repeated that the Special Group had been meeting once a week. Its activities are largely secret because "the U. S. does not want to tip its hand to the Reds, and some countries do not want to admit they have an internal communist threat."

3. Issue of June 27, 1963.

4. Charles W. Thayer, Guterrilla (New York: Harper, 1963), p. 187.

5. Lieutenant Colonel Gustav J. Gillert, Jr., "Counterinsurgency," Military Review, XLV, No. 4 (April, 1965), 25-33.

6. Department of State Bulletin. March 18, 1963, p. 405.

7. For details on the creation and functioning of this new devision, see Department of Statc Nezusletter, No. 30, October, 1963, pp. 24-26.

8. House Committee on Foreign Affairs, Hearings, Foreign Assistance Act of 1964, 88th Cong., 2d Sess., H. Rept. 10502 (March 23-25; April 6-10, 13-17, 20-24, 27-30; May 1, 4, 5, and 6, 1964), Parts 1-7.

9. The Washington Star, June 27, 1965: "Army-State Dept. Feud Bared by Chile Incident. Diplomats See Pentagon Political Study as an Invasion of Foreign Policy Field."

10. Thayer, Gucrilla, p. $187 \mathrm{ff}$.

11. Alexis Johnson, "Is the Service Ready for the Sixties? Internal Defense and the Foreign Service," Forcign Service Journal, July, 1962, p. 20. 
12. The Venezuela Fuerzas Armadas de Cooperacion (FAC), a kind of well-regarded National Guard, takes the lead in literacy, reforestation, rural medical services, and comparable tasks.

13. Letter to the authors from chief of MAAG Mission, La Paz, March 17, 1965.

14. Letter to authors from United States Embassy officers at Buenos Aires, March 8, 1965.

15. A lengthy article entitled "The Role of the Army in Education, Scientific Investigation, Industry, and Civic Action," Revista del circulo militar, No. 670, October-December, 1963, p. $21 \mathrm{ff}$., emphasized highway construction and literacy statistics. In the Revista de la Escucla Superior de Gucrra, XLII, No. 352 (January-March, 1964). 151 ff., appears the outline of the course of studies for the higher military institutes, showing the attention devoted to civic action.

16. Memorandum of December 28, 1964, from an officer of the United States Embassy at Mexico City, to the authors.

17. A slick-paper, profusely illustrated Honduran publication Accion cizica (undated), issued in 1964 by the Ministry of Defense.

18. This point was emphasized in leading articles and an editorial in an undated issue of publication Acción civica, published by the Honduran government in 1964.

19. Kevista militar de Honduras, Vol. III, No. 5 June-December, 1962, passin.

20. Quoted in a lecture delivered by Colonel T. M. Ashton at the Inter-American Defense College, January 29, 1963.

21. A detailed account of the origin and the operations of Guatemalan civic action is presented in an unpublished briefing paper prepared by Major Carl L. Krueger, United States civic-action adviser to Guatemala. Major Krueger had previously served in a similar capacity in Korea.

22. Harry F. Walterhouse, "Good Neighbors in Uniform," Military" Rericw, XLV, No. 2 (February, 1965), 10.

23. Unclassified report, "Conclusions Concerning the Topic of Civic Action, Discussed November 10-12, 1964 [at Fort Gulick, Canal Zone]," mimeo. (December 8, 1964), p. 25 (the author's translation irom the Spanish).

24. Article and photographs on pp. 28-29 of the Honduran publication Acción civica (undated), issued in 1964. 



\section{Chapter 5}

\section{Training}

A variety of activities performed by military units, ranging from riot control and other internal security measures on the one hand to such programs as road-building, disaster relief, and exploration on the other, had been performed as a matter of course for decades prior to 1960 , both in the United States and in the other American republics. Such functions were not new, although the terminology and context in which they were discussed at some length in chapters 2 and 3 placed special emphasis on these functions in the years 1960-62. And the impetus supplied by President Kennedy (in keeping with the slogan of the recent electoral campaign "to get the country moving"), Attorney General Kennedy, and Special Military Adviser General Maxwell Taylor was of considerable force. Repeated statements were made in regular and special messages to Congress, in press conferences, in TV appearances, in talks or messages to military meetings, and to groups 
of government employees. Promotions and special assignments were handed out; transfers of personnel pointed up the active and direct personal interest taken by the President and by the Special Group. Spokesmen known to represent the President's views delivered lectures and wrote articles appearing in official and professional publications. Counterinsurgency and military civic action were de mode: they were "in." Funds were appropriated, and the theory of counterinsurgency and civic action flourished. To put these concepts into action, orientation and indoctrination was necessary. Civilian and military personnel, accordingly, at all levels, needed to be exposed to, and drilled in, the theory and practice.

The concern of the President and his top assistants was reflected in efforts to train United States as well as the Latin American armed forces for counterinsurgency operations. Additions of new courses, or material, were made to the curriculums of the country's major military training institutions.

In 1961, the President asked Congress for funds to support an increase in army personnel strength to permit expansion of guerrilla warfare units. These units were soon increased by approximately three thousand. Early the next year, the Army Special Forces numbered 3,800, with 937 more in training at the Special Warfare Center at Fort Bragg. This strength, scheduled to expand to 5,000 by June 30,1962 , actually reached 5,600 early in 1963 .

On June 10, 1962, the State Department announced that in co-operation with other agencies of the government, it was inaugurating a series of seminar courses called the "National Interdepartmental Seminar on Problems of Development and Internal Defense." For 
administrative purposes the seminar was organized under the jurisdiction of the State Department's Foreign Service Institute. The official announcement declared that, "The Seminar demonstrates the United States" determination to assist the less developed countries of the free world in developing balanced capabilities for the total defense of their societies against internal as well as external threats." 1

The broad purpose of the seminar, popularly known as the "Counterinsurgency Course," is to develop more co-ordinated and harmonious operations at the Country Team level. To this end, it seeks to relate the study of insurgency to the political, economic, and social context in which it occurs. Medium and senior grade officers of all agencies represented abroad are familiarized with each other's business and with the resources of the United States government to assist the less-developed countries of the world in suppressing insurgency. Each seminar lasts five weeks and is repeated six or seven times a year." According to a State Department report, an average class of sixty-five "will include three or four Ambassadors, a couple of Generals, and eight or ten Colonels, ten to fifteen Mission Directors or other senior AID officials, six or eight country Public Affairs Officers and a sprinkling of Deputy Chiefs of Missions, Counselors of Embassy and Principal Officers.":

In view of the requirement for special air-borne forces to meet counterinsurgency problems, the air force, in 1962, announced the activation of a Special Air Warfare Center at Eglin Air Force Base in Florida. This center now conducts training in special air operations and develops special warfare technique in counterinsurgency operations. It also works closely with the army's Special 
Warfare Center at Fort Bragg. The marine corps also gives counterinsurgency training and indoctrination at all levels. The Fleet Marine Force receives instruction in special warfare techniques.

The Military Assistance Institute (MAI), Arlington, Virginia, offers a month-long course ten times a year with 100 officers in each class in preparation for the technical instruction and administrative duties that would be performed abroad as members of Military Assistance Advisory Groups (MAAG's). Lectures by officers from the departments of State and Defense, the Agency for International Development (AID), and the United States Information Agency, as well as attention to area studies, comprise the program of instruction of MAI. The director of MAI placed eighth in a list of ten principal MAAG policies in which MAI is to orient the student "to the extent consistent with U.S. objectives and policy, identify and assist in civic action projects." The ninth was to "develop counterinsurgency forces and plan for their utilization." It is of interest to note that fourth in the list of ten directives was to "further the sales of United States-produced military equipment to meet valid country requirements." 4

\section{School of the Americas}

The Army Caribbean School in Panama," renamed the United States Army School of the Americas on July 1, 1963, was founded February 1, 1949, for instruction of United States Army technicians. A secondary mission was to instruct Latin Americans. Today, the formal mission of the school is to support the United States Army Southern Command effort in South and Central America 
by conducting, in Spanish, training courses for Latin American military personnel designed to strengthen the internal security of their republics in peace and war. Since its inception through 1964, 16,343 Latin American students (officers and enlisted men) from nineteen countries and 9,876 United States students have graduated from the school. Approximately 1,400 graduated in 1963 and about the same number in 1964. The 16,343 Latin American graduates as of the end of 1964 represented the following countries:

Country

Number

Argentina

Bolivia

1,124

Brazil

165

Chile

Colombia

Costa Rica

Cuba

291

Dominican Republic

Ecuador

1,478

El Salvador

Guatemala

Haiti

Honduras

Mexico

Nicaragua

2,969

Panama 1,420

Paraguay

Peru 
In the case of Brazil and Haiti, the language obstacle has limited attendance. Some other countries with small representation have well-established military-school systems of their own. Furthermore, the representation shows a large number of graduates from the nearby countries where traveling expenses would be a minor factor. This includes both Panama and Costa Rica, countries which are often described as "having no armies." In each case, however, many essential military functions-going beyond police duties-are performed by units of the national guard in those two countries.

The school's normal student load at any one time would consist of between 350 and 500 Latin American students. The courses run throughout the calendar year, with the exception of December. Two cadet courses are conducted regularly. One is given annually during January for Peruvian military academy cadets who are given an exposure to many of the courses given at the school. The other, a regular cadet course, forty weeks in length, has representatives from two to four of the Latin American academies. Faculty and staff consist of officers and enlisted men, of both the United States and Latin American military establishments. The school has two instructional departments: the internal security department and the technical department. Courses vary in length from the two-week counterinsurgency orientation course, the shortest, to the forty week command-and-staff, and cadet courses.

In shifting its instruction from hemispheric defense to internal security, the School of the Americas has exhibited the same shift in emphasis that was observed in Washington, both in legislative and executive branches of the government in the same time span. The instruc- 
tion covers the entire spectrum of military arms and services from basic subjects to advanced planning and organizational concepts. But nearly every course has some application to counterinsurgency which in the past two years has received an increasingly greater share of the time in the various course curricula. Accent is placed on the need for collaboration between the military and other governmental agencies that are engaged in counterinsurgency activities.

A recent listing gave the school's Department of Internal Security the folowing subjects: Counterinsurgency operations, military intelligence, military police, command and staff, infantry, jungle operations, and air-borne. Thus, that department provides instruction in every aspect of counterinsurgency: military, paramilitary, political, sociological, and psychological. Stimulation of economic growth by military civic action is emphasized. Illustrative of this emphasis are courses in operations and maintenance of heavy engineering equipment. After the closing of the jungle warfare training center at Fort Sherman, a course in jungle operations was added to the School of the Americas' curriculum. Skills necessary to fight in the jungle are taught in that course, contrasted with the United States Air Force's Tropical Survival School located at Albrook Air Base in the Canal Zone, which is designed to teach grounded pilots how to survive in the jungle, pending rescue.

At the School of the Americas, civic action has, since July, 1961, been included as a part of a ten-week course on counterinsurgency. The civic-action aspects of the course deal with problems and methods of organizing a program, the theory and practice of community development, public relations and publicity, and national 
economic development theory. A three to five day field trip takes the students to a selected Panamanian village for a practical survey and report. The reports analyze the community's problems in agriculture, education. community organization, public health, and natural resources. Recommendations based on these studies are turned over to the Panamanian National Guard for whatever use it chooses to make of them. Officials at the School had (as of April, 1965) submitted a proposal for an annual three-week course devoted entirely to civic action. Approval was made contingent on the number and quality of students who would be sent by interested Latin American governments.

A number of officials of the School feel that most of the related technical courses offered there accomplish as much as the teaching of civic action per se. For example, courses are offered in the maintenance and operation of small motor vehicles, tractors, cranes, and earth moving equipment. An elementary course in communications and a basic medical technicians course for non-commissioned officers are equally related to civic action. All of these skills are obviously basic to any civic-action program.

\section{The Army Special Wartare Center and School}

Much of the improved quality of training at subordinate schools and posts is due to the leadership and planning of Major General George T. Duncan, chief of staff at the United States Continental Army Command (CONARC), who issued a comprehensive directive in May, 1964, for mobile training teams, special and back-up 
forces, and for the army reservists. Under the supervision of conarc is the Army Special Warfare Center at Fort Bragg, North Carolina. It was created in 1956 with the responsibility of developing doctrine and training selected personnel in the special forces and psychological warfare units. In 1960, the center was given the additional duty of developing doctrine and conducting training in counterinsurgency operations. An important element in the center's activities is the Army Special Warfare School, to which the navy, air force, and marine corps, as well as the army, send officers for training. By the end of 1963, 112 Latin Americans had attended the Special Warfare School. The table below shows the number of students from individual Latin American countries:

Country

Number

Argentina ...................... 19

Bolivia ..................... 23

Brazil .......................... 2

Chile $\ldots \ldots \ldots \ldots, \ldots \ldots \ldots \ldots$

Colombia $\ldots \ldots \ldots \ldots \ldots \ldots \ldots, \ldots \ldots, \quad 5$

Costa Rica ..................... 1

Ecuador ........................ 14

El Salvador $\ldots \ldots \ldots \ldots \ldots \ldots \ldots$

Guatemala ....................... 13

Haiti $\ldots \ldots \ldots \ldots \ldots \ldots \ldots \ldots \ldots . \ldots . \ldots 1$

Honduras $\quad \ldots \ldots \ldots \ldots \ldots \ldots \ldots \ldots \ldots$

Mexico ........................ 3

Nicaragua $\quad \ldots \ldots \ldots \ldots \ldots \ldots \ldots \ldots . \ldots . \ldots$

Peru .......................... 4

Venezuela ........................ 11 
The courses at the Special Warfare School are on such subjects as special warfare, psychological or counterinsurgency operations, and unconventional warfare. Minor attention is given to civic action, although there are some short courses in this subject. These latter courses discuss the applicability of civic action in countries facing varying threats to their internal stability. The advantages to the country - and to its military personnel -arising out of military civic action, are stressed. The procedures to funnel assistance to host countries, through the United States diplomatic missions and the MAAG's, and the funding formula are also covered. For a précis of the Counterinsurgency Operations Course, see Appendix $\mathrm{F}$.

In 1963, Assistant Secretary of State Martin reported that Latin American military personnel were receiving training at Fort Gulick, Canal Zone (the School of the Americas) and at Fort Bragg, "in riot control, counterguerrilla operations and tactics, intelligence and counter-intelligence, and other subjects which will contribute to the maintenance of public order, and the support of Constitutional governments." "He added that "This assistance is being provided for the control of Communistinspired civil disturbances, for vigilance and control of movements and subversives and arms inside those countries and across their borders, and for the maintenance of observation and patrol of rural areas for detection and dispersion of guerrilla movements." 


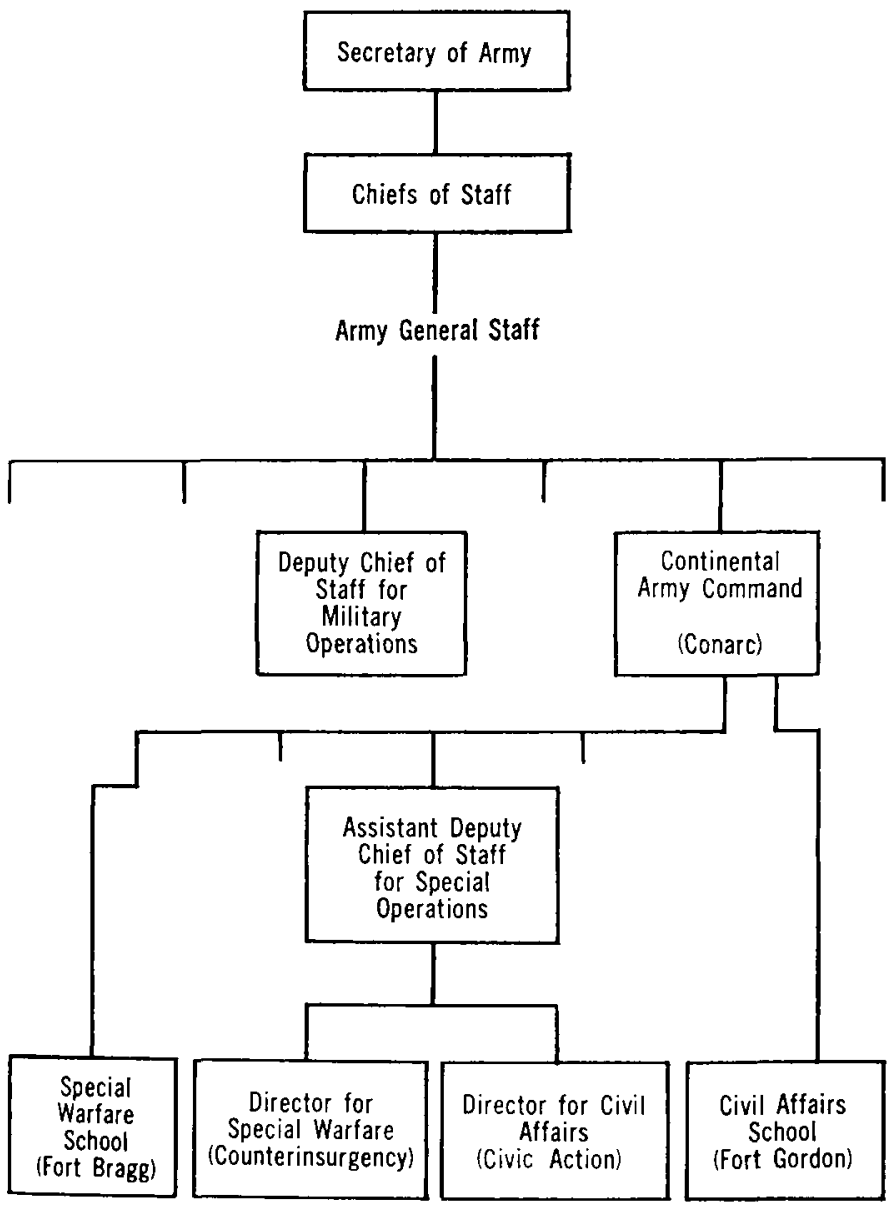

FIG. 5.-United States Department of the Army organizations for counterinsurgency and civic action. (Civil Affairs School, Ft. Gordon, Ga., 1964.) 


\section{The Army Civil Affairs School, fort Gordon, Georgia}

At Fort Gordon, courses in the program of instruction for civic action extended over a period of six weeks (as of July, 1964). Although some civilians attend the courses, the students are mainly warrant or commissioned officers. They may be under assignment to a MAAG or mission group, to civic-action mobile training teams, as civil affairs augmentation to special action forces, or to command staff or faculty positions pertinent to training in counterinsurgency. The curriculum covers subjects such as the concept and basis for civic action, organization of non-military agencies, military organization involved in civic action, and psychological operations in counterinsurgency. Study also includes cultural influences, administration logistics, and the development and demonstration of military civic-action projects. Instruction is carried on by conferences, lectures, demonstrations, seminars, research, and practical exercises. Some military personnel from friendly governments attend the courses.

In the survey of operations problems and the choice of types of projects susceptible of civic action, attention was paid to engineering, and public works, health and sanitation, agriculture, education, public administration, communications, economics, village-level projects, "handling people in masses," and relocation of populations. Time was also devoted to sociological aspects of civic action with emphasis on community development and the economics of development programs. Reading assignments for the students included Department of Defense 
classified staff studies; the traditional books written by Rostow, Milikan, and Osanka; congressional committee reports; the Department of Army field manuals; and reports prepared by research organizations. The section of the course on non-military agencies included examination of the organization, objectives, and policies of the USIA, AID, and international agencies such as the UN, WHO, FAO, and UNESCO. CARE and other private agencies were also covered. One week was spent on the experiences in Vietnam. From the Philippines came illustrations drawn from the Huk insurgency, of agrarian reform, the conduct of free elections, and caring for civilians in army hospitals to supplement military civic action. From the Korean experience (AFAK) came the idea originated in 1953 by General Maxwell Taylor, then Korean commander, that surplus construction materials be used by the United States military personnel to help Korean reconstruction. (President Eisenhower approved of the plan, as did United States Congress, which authorized this program in November, 1953, and eventually appropriated $\$ 20$ million for its support.) The purpose of the course is "to provide commissioned officers, warrant officers, and selected civilians with a working knowledge in planning, developing, programming, administering, and expanding, as necessary, military civic action programs and activities."

In the Fort Gordon lesson plan, "The Concept of Civic Action," one encounters the official definitions, doctrine, and orientation." It starts with excerpts from President Kennedy's inauguration speech and his March and May, 1961, messages to Congress, in which he emphasized that military assistance would in the future 
more heavily emphasize internal security, civil works, and economic growth. The lesson plan states that one of the key directives on civic action that governs all agencies of the United States national government is National Security Action Memorandum No. 119, issued in December, 1961. Here the President defined three situations wherein civic action would be useful:

1. To strengthen military-civil relationships in countries combating active internal subversion.

2. Military civic action projects should not impair the military role of the armed forces in countries threatened by external aggression.

3. Local military forces can contribute to economic and social development, where neither internal subversion or external attack is imminent.

The method used at Fort Gordon is first to ascertain the economic and social causes of insurgency. Having done this, the armed forces, representing as they do an important force for cohesion and unity, should, it is pointed out, devote more of their effort and resources to relieving these causes of distress; the method to be used is civic action.

The navy, air force, and marine corps assigned personnel to the various courses and schools devoted to special warfare and civic action that are operated by the Department of the Army, including those at Fort Bragg, North Carolina and Fort Gordon, Georgia. Navy and army personnel have also attended the schools and courses administered by the air force. Officers from each military service attend the national Interdepartmental Seminar on Problems of Development and Internal De- 
fense and other courses offered at the State Department's Foreign Service Institute. Of officer assignments to Latin America, by far the largest number of United States military personnel are from the Department of the Army. Approximately 85 per cent of all mobile team members are from the army, the remainder being from the air force, navy, or civilian agencies.

\section{The Inter-American Geodetic Survey}

Illustrative of the many facets of training and consultation by personnel engaged in collaboration with the Latin American military is the operation of the InterAmerican Geodetic Survey (IAGs) since 1946. Since 1955, IAGs has been a separate, subordinate command of the United States Army Southern Command, operating at Fort Clayton in the Panama Canal Zone. Corps of Engineers' officers and civilian employees largely staff the IAGs. Agreements were negotiated with all of the Latin American governments, except Argentina, Uruguay, Cuba, and the Dominican Republic, to arrange for the exchange of technical data on mapping, translations, fixing elevations and tide levels, and other scientific and technical aspects of geodetic, topographic, and cartographic activities. The normal complement at IAGs has grown to over 750 individuals, about one third of them military personnel. In a number of Latin American countries, small field offices are established both to supervise air- and surface-mapping work, and to furnish liaison and training services to the host government. A large portion of the "resources expenditures" as the IAGS describes it, now amounting to approximately 
$\$ 12,000,000$ per year, is for the aircraft, service vehicles, precision instruments, and communication equipment. A cartographic school has been maintained by the IAGS since 1952. It provides training with bilingual instructors in astronomy, cartography, field surveys, photogrammetry, geodetic computing, drafting, and aerial photography. In 1964, approximately two hundred Latin Americans attended this school, bringing to over sixteen hundred the total number of Latin Americans receiving training since 1952 . This total includes civilians, military officers, and enlisted men. Facilities, serrices, and equipment are supplied by the United States government for the courses that vary from five to forty-three weeks in length. Subsistence costs of Latin American students, when requested by their sponsoring governments, are often paid from MAP or AID funds.

In 1963, IAGs contracted with the AID's Regional Office for Central America and Panama (Rocap) to provide extensive technical assistance and training and special purposes maps for a general inventory of physical resources in the Latin American countries. For these purposes the IAGs set up a Natural Resources Division in 1964 that has actively collaborated with all the countries of Latin America except Argentina, Bolivia, Chile, Panama, Uruguay, and Venezuela. This colaboration took the form of sending or receiving consultants on land classification, water resources, and national programs of resources inventories. The Natural Resources Division works closely with Rocap and with the InterAmerican Institute for Agricultural Science (IICA) at Turrialba, Costa Rica. An additional Central American program now under way, is for land surveys and to assist the Central American Bank in determining the 
feasibility of loan proposals for resources development. These programs are directly related to short- and longrange Alliance for Progress programs and have received AID financial support in the amount of somewhat less than one million dollars per year.

Latin American participants in the IAGs activities comprise both military and civilian personnel. Inasmuch as the United States military involved are, for the most part, specialists, there has been an unusual continuity of relationships between Latin American and North American participants in both military and civilian categories, which is perhaps unique in the history of either military or economic assistance projects. The IAGS has intentionally emphasized continuing personal relationships with the result that a reservoir of good will and friendly officials in host governments have allowed it to continue its work despite a number of major political disturbances and still to retain an acceptable working relationship with each new government. IAGs Cartographic School Alumni Clubs have been formed in twelve Latin American countries.

\section{Mobile Training Teams}

"Mobile Training Team" is the term used to describe a unit (usually funded by the Department of Defense or AID), which is sent to advise or train personnel of a foreign government in a variety of techniques and, in turn, to enhance that government's ability to provide further training. Since the Third Civil Affairs Detachment, United States Army Forces, Southern Command, Fort Clayton, Canal Zone, was activated in April, 1963, its specialists (forty officers and thirty enlisted men) 
have served as mobile training teams in fourteen Western Hemisphere republics, where they have been active primarily in civic action. These teams are sponsored in the various countries by the United States Army missions at the request of the particular national government involved. They are called upon to advise or teach about matters concerning engineering, medicine, conservation of natural resources, agriculture, animal husbandry, education, colonization, community development or disaster relief, cattle breeding and diseases, food processing, communications systems, water supply, construction machinery maintenance, transportation, and sanitary engineering.

Teams normally ranging in size from one to six, have on several occasions been requested to extend the original brief time allocated for their Latin American duty. Some teams concentrate on a specific objective, as was the case of a medical team sent to Bolivia in 1963 to help combat an outbreak of hemorrhagic fever. A team from the United States Eighth Army Special Forces Group in the Canal Zone exercised a broader mission in Costa Rica in 1963, by helping to conduct counterinsurgency training of 200 Costa Rican Guardia Civil officers and enlisted men. A six-man team spent several months in Colombia, under AID auspices, to survey and initiate a widely diversified program of civic-action projects encompassing road maintenance, dispensary sites, communications facilities in remote areas, potable water systems in villages, and a basic educational and vocational program for the armed forces.

A survey mission was sent to Peru in April, 1963. Working with two Peruvian colonels, the mission helped the army in the planning of a national office (directly 
under the chief of staff) for administration and implementation of civic action. Later the Peruvian Navy and Air Force requested similar assistance. Another survey was carried out in Venezuela in April and May, 1964. The report, prepared upon the return of the mission, made a number of general recommendations with respect to administration, organization and emphasis of civic action in that country. By July, 1963, the army had sent thirty-three civic-action mobile training teams (MTT) to twenty countries and 140 other technical MTT's were used to improve the technical proficiency of local troops.

On several occasions the United States Army Engineering School, located at Fort Belvoir Virginia, gave special training to members of Mobile Training Teams before they were deployed to Latin America on specific civic-action assignments. It also received Latin American officers, in 1965 enrolling three each from Argentina, Brazil, and Venezuela, and one each from Chile, Colombia, and Peru. During 1963, two teams, one consisting of twenty-five individuals, had short training stints of a few days before proceeding to Ecuador for six months on road construction surveys; a team of three was prepared for three months' service in Peru on supply and maintenance problems. In 1964, six teams, ranging from three to twenty-two men, had up to three weeks training at Fort Belvoir, before proceeding to Chile, Brazil, and Ecuador for two to six months. These teams had such missions as construction, well-drilling, engineering supply, and operation of rock-crushers. That five of the nine teams were dispatched to Ecuador suggests the probability that the services of the early missions proved so useful that repeated requests for engineering services 
were made. It also demonstrates that the nature and extent of a civic-action design may be influenced to a large degree by the make-up of the United States MAAG mission-or of the local military office in charge of liaison with the United States MAAG - where professional background and interests of the individual would dictate the choice of projects to be undertaken.

\section{The Nary: SEABEE Technical Assistance Teams (STAT)}

The navy also has mobile training teams drawn from naval construction forces. The latter are comprised of ten mobile construction battalions (MCB) and two amphibious construction battalions. These battalions are divided between the Atlantic and Pacific fleets. A typical MCB has from eight to seventeen officers and from 250 to 500 enlisted personnel. The majority of the officers are Navy Civil Engineering Corps officers, most of whom are graduate engineers and many are registered professional engineers. Each $\mathrm{MCB}$ has organized two SEABEE technical assistance teams (stat). A typical stat would consist of a Civil Engineer Corps officer and a dozen naval ratings, including construction equipment operators, steel workers, builders, electricians, utility men, surveyors, draftsmen, and hospital corpsmen. Each STAT is prepared to train local personnel or to perform by itself the necessary work in a great variety of construction, repair, and rehabilitation situations.

A sTAT operated in Ecuador, from 1959-62, where it helped in the construction of a new naval academy at Salinas. In Haiti, in 1960, a sTAT constructed a floating 
bridge and highway approaches to re-establish transportation across flooding Lake Miragoane. In 1962-63, a STAT rehabilitated the main pier at Port au Prince using Haitian government funds and United States Navy Construction Battalion tools and equipment. One officer and twenty men were engaged on the project. In Chile from 1960-63, a sTAT rehabilitated the earthquake damaged waterfront and quays at Talcahuamo naval station, south of Valparaiso. One CEC officer and five United States Navy enlisted men worked on this project for twenty-four months. In the Dominican Republic in 1963, a sTAT established and operated a skilled manpower development center to train electricians, plumbers, and automobile mechanics. In each of these instances, the STAT operations were to construct as well as to train. The AID program for Costa Rica sought to rehabilitate the countryside after a volcanic disaster. The seabers constructed a dam to stop the mud flow, and trained technical operators and maintenance men for heavy machinery. Thirty-three seabfes under the command of an officer were engaged in this effort during 1964 and 1965. Adding considerably to the effectiveness of the small number of sTAT's is the background support upon which they can draw from the varied professional engineer resources of the Navy Department's Bureau of Yards and Docks.

\section{The United States Air Force Training}

The accepted concept of civic action was expressed by General Curtis E. LeMay, former air force chief of staff, 
in an address at St. Louis, Missouri, on October, 1963, in setting forth the doctrine toward which air force training was directed. In his words:

The purpose of the non-military operations, such as civic action. is to help eliminate the economic cause of discontent that provicles the breeding ground for insurgency. I place special empliasis on the air aspects of the civic action phase because it involves the principle of nationbuilding and humanitarian contributions. In this way our prospects are improved for preventing or relieving the conditions of unrest which could be exploited by insurgent elements in conducting guerrilla operations. ${ }^{7}$

General LeMay cited training flights of the United States Air Commandos in Latin America in airlifting medical teams and emergency equipment or supplies, and flying rescue teams to Bolivia, Panama, and Peru.

The air force offers a three-week counterinsurgency course six times a year for seventy-five students in each class for middle-ranking officers. One of the three weeks is spent at the Air-Ground Operations School at the Special Air Warfare Center. The subjects covered are the theory and case studies of counterinsurgency, strategy and tactics, the operations of the Country Team, and the role of the air force in counterinsurgency.

The United States Air Force School for Latin America functions at Albrook Air Force Base at the Canal Zone under the United States Air Force Southern Command. Ninety-five per cent of its instruction is given in Spanish, covering technical and administrative training in air force specialties, to officers, airmen, and Latin American government civilian personnel. From 1943 to the end of 1963 , there were 6,200 graduates (of whom only 460 
were officers) from twenty different countries. By June, 1965, the total was expected to be 7,250 . An average class has 21 officers, 17 cadets, and 231 airmen. Courses were given in aircraft maintenance, electronics, radio, instrument training and repair, engine and weapons mechanics, supply, personnel administration, and medical specialties. The school does extensive translation of training publications. Latin American officers and airmen are frequent guest instructors. Enriched and advanced courses are given to outstanding students on instructional methods and management. English-language instruction is given to all students. The School also plans to operate a course (Special Air Operations Course-applicable to counterinsurgency) jointly with the 605th Air Commandos, the School of the Americas at Fort Gulick, and a Sqadron at Howard Air Force Base in the Canal Zone.

At the suggestion of Secretary of Defense McNamara during a visit to the Canal Zone late in 1962, a medical program to be operated by the United States Air Force was included in the then rapidly developing military civic-action program. "The proposal was discussed and enthusiastically received by Command Surgeons from nearly all Latin American countries at the Second Latin American Medical Conference held at Albrook Air Force Base in March 1963." "It was thought that the air force would be particularly suited to assist in the hinterland areas inaccessible by road and water and would thus become the agency charged with the preparation of training and operations. Illustrative of the varied purposes which the air force had in mind was the following statement to justify its training program: 
Several possible benefits of the program were recognized--development of medical and sanitation programs in heretofore untouched areas, extension of the peopleto-people program, the possibility of improving the image of the military in the eyes of the people, reduction of breeding wrounds of insurgency, and subsequent stabilization of governmental structure and democratic principles that could aid the ultimate goal of hemispheric solidarity.

A preventive medicine civic-action team (PMCAT) was devised with public health and medical laboratory technicians. Two classes with some fifty students in each were trained in both 1963 and 1961. Each class lasted approximately six months and emphasized sanitation, pest control, immunization, dental treatment, and basic medical courses. The students came from the Dominican Republic, Honduras, Ficuador, Bolivia, and Paraguay. In January, 1964, this program became a part of the United States Air Force School for Latin America (USAFLA). A revised syllabus was prepared, and six hundred hours of instruction were given in first aid, anatomy, laboratory procedures, sanitation, nutrition, and personal hygiene; field trips to remote areas of Panama were made for practical demonstrations. In 1965, the program was extended. Medical civic-action mobile training trips with a physician and air force medical specialists included a four or five day visit to a remote community without medical services. As many as a thousand patients would be treated on a trip. For psychological reasons, anyone who presented himself would receive some kind of treatment as a first step in establishing the good relations found to be necessary before 
starting with a community hygiene and sanitation campaign. Trips were made to Honduras, Guatemala, and Ecuador. Paraguay was the first, with others to follow, in establishing its own medical mobile training trips as its own personnel were trained. An attempt to bring Amazonian jungle witch doctors into the program did not work out because of language and other difficulties. The United States Air Force plans to spend $\$ 6.3$ million in a five-year, four-phase program. The first phase contemplates the training of five-man teams supplied with a package of drugs, chemicals, dressings, preventive medicine, and laboratory equipment. In the second phase, the medical specialists are to be trained in first aid, and sent back to their respective countries with first aid training kits. The third phase will provide a light Cessna 188 aircraft for local medical training teams in participating countries. The last phase would develop greater air-lift capacity for a complete medical dispensary. Considerable attention is given to public relations.

\section{Special Air Warfare Center, Eglin Air Force Base, Florida}

The Special Air Warfare Center (sAwc) conducts a variety of training, the majority of which is concerned with either the operation or maintenance of aircraft in counterinsurgency activities. In 1964, sAwc trained some 1,400 men of whom approximately one-half were enlisted maintenance specialists. The students are provided academic instruction in subjects related to counterinsurgency, as well as practical training in survival techniques, small-arms marksmanship, combat measures, 
prisoner-of-war training, and language study. Some of the students receive parachute training. sawc does not admit civilians to its courses, nor foreign military personnel. Training for the latter is conducted in the host country by sAwc military training teams upon invitation by the host government. SAwc prefers to dispatch teams whose training programs are tailored to the counterinsurgency requirements of the requesting government because this method demonstrates to the host government how its own resources and manpower can be utilized to combat insurgency. sawc conducts frequent joint training and exercises with the Army Special Warfare Center at Fort Bragg when the emphasis is on special warfare activities. sAwc has no regular liaison with the United States Air Force School for Latin America, the Schools of the Americas, or with the Army Civil Affairs School, although it participates with these institutions from time to time on specific projects.

\section{Air Commando Operations}

The 605th Air Commando Squadron, based at Howard Air Force Base in the Canal Zone, is formed of approximately 520 personnel and 46 aircraft. Its special function, styled officially "Special Air Operations," is to train, in collaboration with United States Army Special Forces, Latin American personnel in techniques of special air operations. The training includes tactics for night and day air drops, low-level navigation, weapons delivery, and operations in unfamiliar territory. One objective is rapid action and close support of ground forces. The training includes ordnance delivery, reconnaissance, aerial supply, and support with transport air 
craft. Another mission of the Commandos is to "develop ways in which air power and air resources can be applied to help develop the economic and social potential of a nation." "Demonstrating the types of assistance that Latin American air forces can provide for their own countries, the Air Commandos have airlifted medical teams and sanitation engineers to isolated villages and have sent mobile training teams to Latin American countries for on-the-spot instruction. A spectacular instance of collaboration was the delivery of medicine and supplies during the 1963 outbreak of hemorrhagic fever in Bolivia. The Commando Squadron conducted training exercises for both United States and Latin American personnel in 1962 and 1963 in the Republic of Panama. Such projects as pure water supply, live-stock improvements, road and air-strip construction were combined with training programs using these field operations as practical exercises. Frequently, local communities took substantial part in the civic-action programs.

Variations of guerrilla warfare techniques, including ordnance delivery reconnaissance and supply functions, are conducted by the Commando units. Another unit operates an air force tropical survival school and training for Latin American aviation personnel. The Commando units also participate in the mobile training teams that, upon request, provide on-the-spot instruction for civic-action programs. By July 6, 1964, the Bolivian Air Force was scheduled to have four air craft to transport preventive-medicine teams and flying dispensaries as well as establishing 28 airfields and 52 landing strips, which are not supported by commercial air lines. The Guatemalan Air Force, during 1963, emphasized air-freight and passenger services and the opening 
of new areas for settlement, in addition to the work of preventive medicine teams.

\section{An Unusual Air Force Project}

There is a little-known, commercial-scientific co-operative activity between Latin American citizens and organizations, on one hand, and the United States Air Force on the other, which is not directly related to weapons or to current military activities. This is a project of basic and applied research, conducted by Latin Americans and paid for by the United States Air Force. Although it may be remarked that this activity is on the periphery of "military civic action," it is an example of a United States military sponsored activity with effects on a small segment of Latin American society. Between 1951 and 1961, the United States School of Aviation Medicine gave financial assistance to the Instituto Nacional de Biología Andina, in Peru, and in the mid 1950's the Air Force Cambridge Research Laboratories (AFCRL) sponsored research at the Instituto Geofísico del Peru located at Huancayo, Peru. The objectives were to study high-altitude problems, including geomagnetic variations, night afterglow, ionospheric absorption, and neutron-monitoring. The Air Force Office of Scientific Research (AFOSR) in 1958 contracted with the Bolivian Laboratorio de Física Cósmica, located at an altitude of 17,000 feet, for cosmic-ray studies. In 1959, additional air force contracts were let for work in Brazil, Chile, Uruguay, and Argentina by the AFosR life-sciences division. Some authorized research was on human biological problems and others on specific aviation 
subjects such as the drag on supersonic air inlets, the aerodynamics of external jet flaps, and meteorology. The Bolivian attempt to detect high-energy gamma rays from space, and extra-terrestrial environment studies, has been considered by the air force to be one of its potentially most valuable Latin American endeavors.

In 1962, a United States Regional Science Office was opened in Rio de Janeiro, combining and co-ordinating research interests of the United States National Science Foundation, the National Institute of Health, and the Department of Defense. This was followed by the receipt of applications for numerous additional research and scientific enterprises, some of which were accepted and financed by the air force or by its contractors in the United States. Among the subjects treated where equatorial magnetic variations, laser-searchlight techniques, and upper air conditions. An important aspect of the air force part of the work at Rio was to arrange for distribution of air force scientific reports to Latin American universities, institutes, and scholars. This "served to emphasize the open 'unclassified' nature of Air Force basic research activities and thereby helped to overcome the scruples originally felt by some Latin American researchers about possible cooperation with a foreign military agency." ${ }^{10}$ In this case, as in the instance of the Inter-American Geodetic Survey, only a few institutions and individuals are involved with a limited effect upon the Latin American military. But this could be an example of opening avenues of future relationships, productive of substantive favorable results to the United States. 


\section{International Police Academy}

Although the United States had offered some training for Latin American police officers as early as 1955, the program was greatly stepped up in size, in the frequency of course offered, and the importance attributed to it in the early 1960's. In 1963, Assistant Secretary of State Martin noted that:

In assessing the internal security situation in Latin America, we found that the civil police forces in many of the countries wanted assistance in police administration, training, and operational techniques and particularly required greater mobility and more adequate systems of communications, largely related to riot control and other threats to public order. Consequently, the public safety program, which is an integral part of the AID program, is designed to meet these requests.

A year earlier, the Inter-American Police Academy had been opened in the Canal Zone; it changed its name to the International Police Academy in 1963 and moved to Washington in 1964. The total number of graduates of the International Police Academy since its opening in December, 1963, has reached 600 . The instruction at the Academy is largely conducted by former police or FBI officers. The training is given in Spanish, and the general course lasts six weeks.

\section{The Inter-American Defense College}

Located at Fort Lesley McNair in Washington (the site of the National War College and the Industrial College of the Armed Forces), the Inter-American De- 
fense College was opened to student officers from all of the American republics except Cuba in October, 1962. Its stated mission is to conduct courses of study on the Inter-American System and the military, economic, political, and social factors that constitute essential components of inter-American defense, in order to improve the preparation of selected personnel of the armed forces of the American republics for undertakings in international co-operation. ${ }^{11}$ The College is a creature of the Inter-American Defense Board, which decided, in 1959, to establish it. Operating funds are provided by the OAS and are administered by the Board. Each member of the OAS may send up to five students, who are normally in the grade of colonel and are graduates of an advanced command or staff school. The first class consisted of thirty officers from fifteen countries. Two classes were graduated in 1963. The third class of thirty-four officers was graduated in July, 1964; and the fourth, with students from fourteen countries, in May, 1965. The curriculum is comparable to that of the most advanced military educational institutes. Considerable time is devoted to international geography, political and diplomatic affairs, and to a study of communist countries and their policies. Military and strategic planning and administration, with special emphasis on Western Hemispheric defense, are other elements of the twenty-two-week course. Lecturers come from the ranks of professors, civilians, and military officers of different nationalities. Most of the instruction is in Spanish and a considerable portion of the student officer's work is done in committees. A comprehensive presentation of military civic action in both its theoretical concepts and in practical application has been made to the College at each session. Specifics regarding Latin 
American military organization and accomplishments in civic action were shown, and problems on this subject were assigned to the student committees. The availability to the students' home governments of United States technical advice and financial assistance for civic action has been made clear to the participants.

\section{1}

\section{Differences and Difficulties in Training Courses}

The strong impetus which President Kennedy gave to the educational and training aspects of counterinsurgency and civic-action programs in 1961 and 1962 immediately resulted in enlarged operations at the Special Warfare Center at Fort Bragg, the School for Civil Affairs at Fort Gordon, the schools in the Canal Zone, and the National Interdepartmental Seminar on Problems of Development and Internal Defense. The attention and prestige attached to the National Interdepartmental Seminar has declined since the first session was opened by Secretary of State Rusk and closed by President Kennedy in a White House ceremony. During that session, the main series of orientation lectures was conducted by a distinguished group of professors from the Massachusetts Institute of Technology led by professors Milikan, Hagan, and Pye. By contrast, the 1964 and 1965 sessions were opened by the director of the Foreign Service Institute and the presentation of the certificates at the end of the respective courses was made by the directors of the seminars. Subordinate officers of State, AID, the Department of Defense, the United 
States Information Agency, and the Department of Labor lectured.

At the most advanced United States military educational institutions (the regular nine-month courses given at the National, Army, Navy, and Air war colleges) only one day or one lecture period was devoted to counterinsurgency and civic action in the 1964-65 academic year. It must be borne in mind that a key objective at those institutions is not to specialize but to give broader and more comprehensive courses for officers previously specialized in one branch or one function of the military services. At the Armed Forces Staff College at Norfolk, Virginia, attended by officers from all branches of the military services, one session is devoted to counterinsurgency and a part of another session to civic action. ${ }^{12}$ At the United States Army Command and General Staff College at Fort Leavenworth, Kansas, where sixteen officers from Latin America were in attendance in the academic year 1964-65, no time was allotted to civic action as a separate subject, but a new topic on the application of civic action in counterinsurgency is to be given for the first time in the last part of the year. ${ }^{13}$ The Industrial College of the Armed Forces has devoted many research assignments, as well as lesson plans and lectures, to counterinsurgency and to civic action as separate subjects.

Most language training given to United States military personnel is under the control of the Defense Language Institute. Full-time intensive training is conducted at Washington, D.C., at the Presidio of Monterrey, California; at the Foreign Service Institute of the State Department; at Syracuse, Yale, and Indiana universities; and at commercial schools in the national capital. 
Many, but by no means all, of the people assigned abroad to MAAG missions receive language preparation before they depart from the United States. Forts Bragg and Gordon give some language training for a relatively short time as a part of their general courses. Refresher courses are given by the Defense Language Institute for four to eight weeks duration for personnel needing to bring back a former language proficiency. Currently, the Institute in its own facilities offers twelve and twenty-four week courses in French, Portuguese, and Spanish on a six-hours-a-day, five-days-a-week basis with a native-speaking instructor for at least two hours a day. ${ }^{14}$

There is little training given to enlisted men in the unique aspects of civic-action duties, although most members of MTT's are in the enlisted men category. In the institutions that they are permitted to attend, such as the Defense Language Institute, the Air Force School for Latin America, the Special Warfare School, and the Civic Affairs School, only a small number of enlisted men have been assigned, and no formal courses were designed for them. An explanation offered for this is the following statement:

Key to a successful civic action effort is comprehensive relatively high level planning, programming, supervision and administration-hence the emphasis on officer rather than enlisted skills. Neither the Civil Affairs School nor the Special Warfare School give an enlisted man civic action course-formal or informal. ${ }^{15}$

The small number of enlisted men receive only a few hours of civic-action instruction as a part of other courses in counterinsurgency or civic-affairs administration. Generally, their training is in technical fields, not 
in the problems and issues of cross-cultural relationships, or pertaining to attitudes or methods specifically pertinent to civic-action duties. Even these courses are brief and provide little or no time for study of the foreign areas and peoples involved. Finally, most of the enlisted men receiving even this sparse preparation were destined for assignments to Vietnam or to MAAG groups stationed in parts of the world other than Latin America. The lack of language training has been mitigated in some cases by the sending of enlisted men to MAAG's in Latin American countries who had an understanding of Spanish as a result of their childhood in Puerto Rico or one of the Southwestern states.

The limited training given to enlisted men may be justified for administrative reasons and for the economyconscious because the length of time that they would spend in the military service is relatively short, and there presumably would be but a grief time to reap the benefits from the investment of training time. Indeed, the admittance of enlisted men to some of the courses at Fort Bragg and Fort Gordon was restricted to those who had a relatively long period of time still remaining in their term of military service. A consequence may often be that the lower ranks of United States military personnel sent to Latin America on MAAG assignments are untrained in civic-action ideology and are soon to leave the military service. They may, therefore, have something less than enthusiasm or a spirit of dedication toward their work.

This is a continuous problem, often the subject of complaint by host government officials faced at frequent interval with new technical assistants. It must be added that with respect to the need for area orientation and 
language training that the enlisted ranks are probably in much greater need of this than are the commissioned officers. The latter are possessed of greater educational background, are older, more experienced, and have a professional sense for opportunity and accomplishment based on a life-long career expectancy. They could, therefore, be expected to adjust more quickly and to serve more effectively than the short-term, young, inexperienced enlisted men. But it is the former rather than the latter who receive the lion's share of the educational and training facilities.

With respect to the officers, there appears to be a growing tendency, entirely laudable, to reduce the frequent rotation of military assignments. In order to make effective use of their previous experience and to fully receive the dividends of the training courses, more officers are now receiving repeated assignments to MAAG and civic-action duties. An illustration of this trend was the assignment as director of the MAAG group at La Paz, Bolivia, of Colonel Jess Unger of the Corps of Engineers. He combined area and linguistic qualifications and had held previous assignments as engineering adviser officer to the MAAG missions in Ecuador (1949-51) and Bolivia (1956-58).

There is reason to believe that departure from the normal peacetime cycle of assignments of army officers from school to command-of-troops to staff duty to school has been considered by many officers as a definite threat to their professional careers and their promotion opportunities. (This is less applicable to Corps of Engineers officers.) Accordingly, service in MAAG's or on civic-action assignments was to be avoided. When the orders came anyway, the tour of duty might be some- 
thing less than full of enthusiasm, imagination, and accomplishment.

A highly respected United States military officer, upon visiting United States MAag's in Latin America, encountered in some places an indifference and apathy toward civic-action tasks on the part of the United States military. The training in specialized techniques, it must be admitted, does not uniformly result in dedication. The whole question of selection and assignment of personnel particularly adapted to the unusual nature of counterinsurgency and civic-action functions is of considerable significance, not underestimated by the authors despite their inability to pursue that subject in depth.

1. Department of State Press Release No. 380, June 10, 1962.

2. Kenneth F. Landon, "New Seminar Studies Ways to Counter Communist Insurgency, Subversion," Department of State Nezesletter, June, 1962, p. 2.

3. Department of State Newsletter, January, 1965, p. 26.

4. Letter of February 18, 1965, from the director of the Military Affairs Institute. It is clear that one of the duties which MAAG officers are expected to discharge is the promotion of armaments sales to Latin American countries. General Wood, director of the Office of Military Assistance, in response to a question by Congressman Joseph Montoya of New Mexico as to the duties of the United States Military Mission to Argentina said: "Their duties are a combination of training missions with the Argentine services, programming military assistance in line with the request of the Argentines, and in cases such as in this country, where a country is able to buy, assisting in promoting sales." On the same subject, Mr. Frank Sloan, deputy assistant secretary of defense for international security affairs, declared: "I said Argentina was one of our best customers in Latin America. They also do some purchasing in Western Europe. We would like for them to do that purchasing in this country also." See "Foreign Operations Appropriations for 1965," Hearings before a subcommittee of the House Com- 
mittee on Appropriations, 88th Cong. 2d Sess., Part 1 (April 14, 1964) pp. 516 and 520.

5. "Communist Subversion in the Western Hemisphere-Continued." A statement by Assistant Secretary of State Edwin M. Martin before the Latin American Subcommittee of the House Committee on Foreign Affairs, February 18,1963, in the Department of State Bulletin, March 18,1963 , p. $406-7$.

6. The lesson plan is a twenty-seven page brochure published by the Army at Fort McPherson, Georgia, in 1964. Much of the doctrine is also contained in the Army's Field Manual 41-10 "Civil Affairs Operations" issued in May, 1962.

7. "Strategic Advantage Is Key to All Tasks" by General Curtis LeMay in Air Force Information Policy Letter: Supplement for Commanders, No. 125 (Washington, D.C.: Internal Information Division SAF-011, Pentagon November, 1963).

8. "The Preventive Medicine Civic Action Program (March, 1965), U. S. Air Force School for Latin America," United States Air Force Base, Albrook Field, Canal Zone. See also Supplement to the Air Force Information Policy Letter for Commanders, No. 132, June, 1964, p. $11 \mathrm{ff}$. (Washington, D.C.: Internal Information Division, Pentagon).

9. Pamphlet, "The Air Commandos in Panama Under U. S. Air Force Southern Command Operational Control," mimeo., undated, p. 17 (probably issued in 1964).

10. "The United States Air Force and Latin American Research," by David Bushnell (former chief of the Historical Division, Office of Aerospace Research, United States Air Force) in Journal of InterAmerican Studies, III, No. 2 (April, 1965), 177.

11. "Defense College of the Americas," Army' Information Digest, Vol. XIX, No. 5, May, 1964.

12. Letter to the authors, November 13, 1964, from the deputy commandant for instruction, Armed Forces Staff College, Norfolk, Va.

13. Letter to the authors, October 24, 1964, from the secretary of the United States Army Command and General Staff College, Fort Leavenworth, Kansas.

14. Letter to the authors, April 19, 1965, from the administrative office of the Defense Language Institute.

15. Letter to the authors, April 12,1965, from the chief officer, deputy chief of staff for unit training and readiness, Special Warfare and Civil Affairs Division, United States Continental Command, Fort Monroe, Virginia. 


\section{Chapter 6}

\section{Civic Action and Counterinsurgency}

As long as there have been governments, there have been those who have tried to wrest power from them, legally or illegally. In recent years the word insurgency has come to be applied to the activities of those who try illegally to wrest power from a government. Historically, of course, there have been international components in such activities, as well as international implications arising out of such internal activities. But the cold-war struggle to align the most remote corners of the earth with one or another of the power blocs (or to keep them out of one or the other) has made the international implications of insurgency more obvious. In our time, we have seen insurgency become an important instrument of foreign policy among the major powers. We have seen also the development of various doctrines of insurgency and counterinsurgency.

One of the more important of the recent developments in the evolution of these doctrines has been the emphasis 
upon the creation of insurgency rather than merely taking advantage of a propitious situation. For example, in La guerra de guerillas, Ernesto ("Che") Guevara maintained that a revolutionary situation can be created and that it is not necessary to wait for revolutionary preconditions to arise. ${ }^{1}$ Nikita Khrushchev had already given the Soviet view on this when he asked, "Can conditions be created where a people will lose their patience and rise in arms?" and answered, "They can."

In response to recent developments and refinements in the doctrine of insurgency, various doctrines of counterinsurgency have also been elaborated. As these doctrines have developed, they have come to emphasize those activities aimed at preventing insurgency from arising, as well as activities intended to contain it once it has begun. Thus, a document prepared for the enlightenment of members of Congress defines counterinsurgency as "all military, political, economic, psychological activities directed toward preventing and suppressing resistance groups whose actions range from subversive political activity to violent actions by large guerrilla elements to overthrow a duly established government."3

An increasing number of writers dealing with military tactics pointed out that insurgency and guerrilla warfare are not exclusively a problem in military strategy, tactics, and training. The militatry aspect is but one component and, when guerrilla warfare is waged successfully, military tactics are co-ordinated with political, social, economic, and psychological factors. The same would be true of counterinsurgency. But, as one observer noted in 1961, although the military had by then come up with a military solution to the insurgency question, "our 
[United States] political planners have had extreme difficulty in matching their political solutions."

Both civilian and military planners in the United States soon looked to domestic and foreign military units as one (but not the only) agency for dealing with some of the political, social, economic, and psychological factors. One of the means through which the military would work in dealing with the non-military aspects of counterinsurgency would be civic action. Civic action by the military, it was believed, would at least help to discourage popular support for insurgent movements and, possibly, even encourage the local population to assist the military in operations against them.

Until very recently, social scientists in the Western world have devoted little attention to the nature of social conflict and societal potential for the use of violence. $^{5}$ In the Soviet Union, it has been studied in depth. Those in the United States who sought to define the relationships between civic action and counterinsurgency, therefore, had little theoretical foundation on which to build. But civilian and military policy-makers could not afford to wait for the uncertain product of some of the projected research into these questions. They had little choice but to act on the basis of experience in other parts of the world and on the basis of "reasonable assumptions" concerning human nature and human relations.

United States officers in Latin America and in Washington have made a number of assumptions concerning the role of civic action as a counterinsurgency measure. ${ }^{6}$ We merely summarize here the more relevant assumptions dealt with in greater detail earlier. 
1. It can be a subtle means of having troops in a strategic location. In an area where there is a threat of insurgency, it might be wiser to send in a battalion that devotes at least a part of its time to construction or other useful labor. It can secure valuable intelligence, and its presence might discourage potential insurgents without antagonizing the uncommitted.

2. It can serve to alleviate some of the intolerable conditions of rural inhabitants and thus make them less inclined to join or assist insurgent movements.

3. It is a means of improving the image of the military, the central government, or both, thus enlisting the co-operation of local inhabitants when the army is in pursuit of rural insurgents.

4. By contributing to the general economic development of the country, it will reduce the danger of insurgency.

5. It is a means of educating the armed forces and civilians by bringing the military into contact with rural problems, inducing communities to work together and by teaching the officers and enlisted men useful civilian skills.

There is, of course, nothing necessarily contradictory about these objectives. A village water supply that improves the standard of living might also improve the image of the military, contribute to the general economic development, induce a community to work together, and serve as a visible sign that the central government is interested in the community. The problem arises only when there is a question of priority: a project that might make a favorable impact in one community versus an economically beneficial but obscure project in another com- 
munity. It was often pointed out by United States officers in the field, however, that an impact, ${ }^{7}$ type of project, whether of immediate economic benefit, might contribute to the general economic development if it reduced the problem of insurgency and disruption of normal economic life. The problem here is that there are no practical criteria for establishing a priority, and almost any project can be justified as a counterinsurgency measure (or of economic benefit) if argued on sufficiently theoretical grounds. A criterion often used was a statement of need by local civic leaders. This might not bear any relation to a national economic-development plan.

\section{II}

\section{Some Civic Action Projects}

Nearly all of the armed forces of Latin America have been used by their governments from time to time to provide services that would ameliorate local hardshipsdisaster relief, construction of a road to an isolated area, or medical assistance to remote areas. Although contemporary terminology was not used, there are historical examples of a military junta or a civilian government using these activities as a means to gain popular support and to consolidate their power. It is probable, however, that in the majority of cases a branch of the armed forces took on, or was assigned to, a particular task of this nature simply because it was the only agency available at the time. This is particularly true in the case of providing communications to remote areas, administering frontier areas, and similar activities. Once 
involved, they simply continued to carry out these duties since no replacement was found. In other countries, such as Paraguay, where military dictatorships have ruled during most of their national history, it is logical that many functions normally handled by civilians would be turned over to the armed forces.

Since 1961, activities that would ameliorate the hardships of a traditionally impoverished community have been more consciously and explicitly linked with the idea of preventing or removing opposition that might take the form of violence. Small impact-type projectsa potable water system, a school, or a farm-to-market road-were recognized as the kind of project readily within the capability of most Latin American military establishments and at the same time the type of project that could be completed rapidly, thus providing the greatest impact. It was to these projects, and the military units selected to carry them out, that the United States lent the major part of its support under the Military Assistance Program or through AID-Alliance for Progress fund grants. The Counter-Insurgency Planning Guide published by the United States Special Warfare School advised that "initial priority should be given to select high-impact projects aimed at establishing the credibility of the Civic Action program. If longer range projects are undertaken, they should be accomplished in stages to permit partial use and allow intermediate evaluation of their effectiveness."

Despite the Defense Department's interest in impact projects, initial emphasis on engineering battalions tended to encourage some over-ambitious road-building projects in several countries. But problems of supply 
and maintenance of heavy equipment and failure to complete projects resulted in a redirection of activities in some countries where United States assistance was involved. In others, road-construction programs have had notable success (Colombia, Peru, and Paraguay). The smaller impact projects are now receiving most United States emphasis in Chile, Uruguay, Argentina, Ecuador, and some Central American countries.

In some Latin American countries the contribution of existing or projected civic-action projects in the area of counterinsurgency is less than in others. As examples, we note five countries (there may be others) where the programs seem least relevant to the society in which they operate-Argentina, Costa Rica, Mexico, Uruguay, and Venezuela. One or more of the following reasons explain this: (1) There is a relatively advanced stage of economic development and high standard of living, and, thus, there is lesser impact of specific projects (Argentina and Uruguay); (2) active welfare and development programs carried out by the civilian government overshadow military civic-action projects (Venezuela, Costa Rica, and Uruguay ); (3) actual or potential insurgency is or has been in the larger urban areas where civic-action projects have not been emphasized or have been so small as to be insignificant in the light of urban problems (Argentina, Venezuela until recently, Uruguay, and Mexico); (t) the military already has a good reputation, largely because it has exercised restraint in its political activities (Uruguay, Costa Rica, and Mexico). It may also be noted that in all of these countries, with the possible exception of the peronistas in Argentina, the great majority of people have been integrated into 


\section{TABLE $3^{*}$}

Draftees in Latin America, by Number, Age When Drafted, and Length of Service

\begin{tabular}{|c|c|c|c|c|}
\hline Country & $\begin{array}{c}\text { Number of } \\
\text { Male Youths } \\
\text { Eligible } \\
\text { Each Year }\end{array}$ & $\begin{array}{c}\text { Number } \\
\text { Taken into } \\
\text { Service } \\
\text { Annually }\end{array}$ & $\begin{array}{l}\text { Age When } \\
\text { Drafted }\end{array}$ & Length of Service \\
\hline Argentina $\ldots$ & 165,000 & 90,000 & 20 & $\begin{array}{l}\text { Army, } 1 \text { year } \\
\text { Air Force, } 1 \text { year; } \\
\text { Navy, } 2 \text { years }\end{array}$ \\
\hline Bolivia ..... & 40,000 & 7,000 & $18-19$ & 1 year $\|$ \\
\hline Brazil ...... & 700,000 & $80-85,000$ & $18-19$ & 1 year $\|$ \\
\hline Chile ...... & 75,000 & 13,000 & 19 & 1 year $\|$ \\
\hline Colombia ... & 155,000 & 20,000 & $18-19$ & $\begin{array}{l}\text { Army, } 2 \text { years; } \\
\text { Navy, } 2 \text { years; } \\
\text { Air Force, } 1 \frac{1}{2} \text { years }\end{array}$ \\
\hline \multirow{2}{*}{\multicolumn{5}{|c|}{$\begin{array}{c}\text { Costa Rica } \uparrow . \\
\text { Dominican } \\
\text { Republic } \dagger .\end{array}$}} \\
\hline & & & & \\
\hline Ecuador .... & 40,000 & 7,000 & $20 \frac{1}{2}$ & 11 months \\
\hline El Salvador & 30,000 & 2,700 & $18-19$ & 1 year \\
\hline Guatemala ... & 40,000 & 3,000 & 18 & 2 years \\
\hline Haiti† ..... & & & & \\
\hline Honduras $\ddagger$. & & & & \\
\hline Mexicot .... & & & & \\
\hline Nicaragua§ . & & & & \\
\hline Panama $\dagger \ldots$ & & & & \\
\hline Paraguay ... & 20,000 & 11,000 & 18 & 2 years\# \\
\hline Peru ...... & 20,000 & 15,000 & 18 & 2 years \\
\hline Uruguayt $\ldots$ & & & & \\
\hline Venezuela & 80,000 & 7,000 & 18 & 2 years \\
\hline
\end{tabular}

* Source: Hearings on Foreign Assistance Act, 1965, by Committee on Foreign Affairs, House of Representatives, 89th Cong., 1st Sess. March, 1965, p. 350.

$\dagger$ All volunteers.

t Conscription available for 18 -month period of service, but volunteers fill needs.

$\$$ Conscription authorized, but volunteers fill needs.

il Usually released earlier.

\# One year if in Chaco. 
the political system, although in Venezuela this has been a very recent development.

The Southern Command's report for a ten month period (March 1, 1964, to January 1, 1965) lists the following "most important civic action projects which will benefit the largest number of persons," in Argentina. ${ }^{8}$ For the army, it lists nineteen bridges (completed or under construction) five sections of road construction (mileage not given), two projects of wharf or dock construction (size of operations not indicated), a drain construction, and a levee flood protection project. The navy and air force undertakings were more limited and specialized in humanitarian projects (emergency transportation or disaster relief), sporadic public relations (5,000 school children brought to Buenos Aires to visit the Air Force Museum), or activities that most civilians are unaware of (such as hydrographic services). Although these are undoubtedly worthy efforts, it is difficult to see how even a doubling of them would have any appreciable effect on any of the aspects of counterinsurgency described above.

In Venezuela, a somewhat similar situation prevails." The army's principal civic activities were confined to road construction in the remote Gran Sabana area, far removed from the scenes of insurgency. Three projects, when completed, were to provide about 340 kilometers of road. Expected completion date or progress to date was indicated for only one of the projects-twenty-five kilometers completed (out of a projected ninety) in the first three years. Compared with the vast roadbuilding program of the Ministry of Public Works during recent years (nearly seven thousand kilometers in five 
years), these figures are insignificant. ${ }^{10}$ The army has also instituted a program of industrial and agricultural training which will have lasting benefits to the recruit after he has left the service. This program is only beginning but can make a worthwhile contribution to the government's total educational efforts.

The Fuerzas Armadas de Cooperación (FAC) have for years been engaged in civic-action projects and according to virtually all observers have the best reputation among the rural population. They were organized for a variety of functions, including interior police duties, and highway, border, and forest patrol. Stationed in very small units throughout the country, they have carried on literacy training programs, sanitation programs, and other educational activities. During 1964, there were 59 centers for adult education with 44 fulltime instructors, 79 part-time instructors, and 1,318 students. In addition, the FAC operated 35 schools for children with an enrolment of 1,300. The FAC, however, is a very small force (about ten thousand men) and is used only rarely in antiguerrilla operations in the interior. It is organized into small detachments and is unaccustomed to operating in groups larger than about twenty men.

In the North Andean countries (except Venezuela) and in two of the Central American countries, civic action seems to be having a greater impact. This is only partly because of the more ambitious civic-action programs carried on by the armed forces in these countries. All of these countries, it should be noted, are among the lesser developed countries of Latin America. Thus, programs that would be relatively unimportant in the total 
national picture of the more developed countries might be important in the lesser developed countries and make a deeper impression for this reason.

The Southern Command's report (March 1, 1964 January 1, 1965) shows five major areas of civic action in Bolivia: ${ }^{11}$ road construction (especially for colonization areas), clearing of land for colonization, school construction, community development, and primary medical treatment for remote areas. During the last half of 1964, approximately 130 kilometers of roads had been constructed or improved. Engineering battalions were maintaining about 5,000 kilometers of roads and six different road-construction projects totaling about 325 kilometers of road were under way in 1965. About sixty-five kilometers had been completed at the time and projected completion date for all projects ranged from 1965 to 1968 . Semimilitary units, similar to the United States Civilian Construction Corps, were also clearing colonization areas for agricultural development and constructing homes and public buildings. At least one airstrip had been completed to provide communications between a major colonization area and established centers.

Reports on school construction vary slightly, but at least one hundred rural schools had been constructed between 1962 and 1964. Among these were forty-two out of a total of sixty-two that had been assigned to civilian contractors but were later taken over by the army. The army was scheduled to build 156 schools during 1965 with an eventual goal of 1,000.

The projects listed above, especially school construction, are sometimes a part of a broader community de- 
velopment program, the idea of which is to encourage the community to contribute something of a solution to its own problems. The latest Southern Command report showed five such projects under way. Water systems, schools, public health facilities, and street improvement programs were the major projects under construction. Only a small military force (usually from one to four officers and ten or fewer NCO's) is used to mobilize as much of the community as possible.

Another of the more impressive programs has developed in Peru. ${ }^{12}$ Six Peruvian engineering battalions and one separate company are working on construction and maintenance of penetration roads. A seventh battalion is now being formed and equipped for this work. The projects listed for five of the six battalions totaled 768 kilometers, but estimated completion date was given for only about one-half of them-1964 to 1970 . These roads are being, or have been, constructed through some of the most hazardous terrain in the world and have required, in at least some cases, the rapid conversion of combat battalions into engineering battalions. In many cases, they have worked in areas where private contractors were uninterested and where the army has been able to do the work at a lower cost. When completed, the roads are expected to open colonization areas of more than three and one-half million acres of rich and potentially productive agricultural land. President Belaúnde in 1965 announced that he intended for the military to be responsible for one-half of all new road construction undertaken in Peru.

The other major activity in Peru has consisted of vocational training for recruits. Starting only in April, 
1962, at the Lima training center, the program comprised four centers in early 1965, training 3,000 men a year in ten different trades. Concentration is upon simple trades desperately needed throughout Peru, such as plumbing, carpentry, electronics, mechanics, and simple building construction. A vocational agricultural center was scheduled to open in 1965 . USAID, through modest grants, has assisted this program of the Peruvian military under the Alliance for Progress. A wide variety of other activities of the Peruvian armed forces, such as communication with and medical services for remote areas, are worthwhile activities but only marginally connected with counterinsurgency and, thus, not considered here.

In neighboring Ecuador, ${ }^{13}$ the armed forces have also increased their civic-action programs. Beginning in 1962, the main emphasis was upon farm-to-market roads. Four problems appeared very quickly: (1) Activities attempted were beyond their capabilities - too many roadconstruction projects were started without sufficient equipment and know how; (2) there was a lack of maintenance of heavy equipment; (3) the tendency arose to pull out equipment from one project to begin another; and (4) disagreements over projects occurred when officers, including the minister of defense, wanted to institute projects for personal, political reasons, or when officers in charge of project priority determination were transferred. (Ecuador had seven ministers of defense in a period of one and one-half years.)

At one point, the United States Agency for International Development refused to grant any additional funds (for a discussion of AID's role in civic action 
see page 108), but agreement was subsequently reached for their restoration. Although continuing to work on road projects already started, concentration has now turned to less ambitious projects that can be completed within a reasonably short period. The Southern Command's 1964-65 report shows four road-construction projects totaling 173 kilometers under construction and one major project for construction of potable water distribution systems. There are also twenty-eight smaller impact-type projects, including such things as construction of schools, water systems, short roads to isolated villages, electric power lines, and sewerage systems. These twenty-eight projects were strategically spread throughout the country and involved only a few military personnel (usually two or three) serving as technicians, directors, advisers, or co-ordinators. The armed forces or AID also provide equipment locally unavailable. The community usually furnished the bulk of the labor, partly as a matter of necessity and partly as a conscious effort to involve the local community in the solution of its own problems.

In April, 1962, the Colombian military forces and the United States Army Mission developed a plan of civic action that would be carried out by Colombian military personnel and would involve such activities as construction of penetration and farm-to-market roads, community development, health and sanitation programs, welldrilling, and educational programs. ${ }^{14}$ Under this plan for civic action, the Colombian military would supply the equipment and materials and the work would be accomplished jointly by the military and area populace. On completion, the project would be turned over to the community authorities. 
For our purposes the most important areas in which civic-action work is in progress are:

1. Road Construction and Maintenance: Some 300 miles of secondary, farm-to-market roads (later extended to 690 miles) were planned for construction or reconstruction. In 1963, Colombian Army engineering battalions were reorganized, new training methods were introduced and work had begun in four locations (departments of Huila, Caldas, Tolima, and Santander).

2. Medical Dispensaries: Eighteen medical dispensaries (all of which have now been completed) plus two floating dispensaries on the Putumayo and Magdalena rivers and a flying dispensary were programmed. Staffing is by both civilian and army and air force medical personnel.

3. Potable Water Supply: Three well-drilling units were provided under the MAP program. Crews have been trained and four of forty programmed wells have been completed. One of these is in Quebrada Negra, Tolima, where à complete chlorination, filtration and distribution system was also built by the army for the community.

4. Tolima highicay: This project calls for the construction of ninety-six miles of highway between Ataco, Tolima, and Palmira, Valle, plus thirty miles of connecting road in one of the most active violence areas. Army units are working from both ends, and MAP equipment has been provided to support this project.

5. Armed Forces Literacy Education: A program of literacy cducation has been introduced in military basic training centers for illiterate recruits. Helped by AIDsupplied electronic teaching equipment, the program 
teaches reading, writing, and simple arithmetic on the "one teach one" principle in which the recruit is urged to teach one other person to read and write. Two cycles of trainees totaling 7,000 have completed training since November, 1963, with the result that the percentage of illiteracy in the army has droped considerably.

In late September, 1962, a new plan was devised. This was called an "Impact" program and would stress projects within the areas where internal security was a big problem. This was an obvious attempt to stamp out the causes of the violence as well as an attempt to better the "image" of the military in the eyes of the people of the areas. One of the projects given top priority was the construction, improvement, and maintenance of roads so that commerce could flow once more, as well as providing a means of opening areas to motorized patrols. Necessary reorganization of Colombian Army Engineer Battalions was started and new training methods were introduced at the Colombian Army Engineer School. It was decided, to provide better practical experience, that emphasis should be placed on "on the job" type training. By doing this, heavy engineering equipment could be placed on construction site, and construction could go on concurrently with training. Equipment was to be provided from Military Assistance Program (MAP) funds with soft goods support (materials and fuels) from United States AID funds.

We have not attempted to fit Brazil into either of the two categories of countries discussed above. Few if any of the armed forces of Latin America have had as good a record in the field of civic action as have the Brazilian armed forces. Few if any of the armed forces of Latin 
America have as favorable a popular image as have the Brazilian armed forces. It is tempting to draw an easy cause and effect relationship here between civic action and a favorable popular image. Unfortunately, there are too many other factors that would have to be measured first-their record of political intervention, the social origin of their officer corps, their record in national wars, Brazil's relationship with neighboring powers, and many other factors. In their civic action, the Brazilian armed forces have concentrated principally on three areas: (1) road and railroad construction, (2) opening of the frontiers and servicing remote areas, and (3) in-service training of recruits in civilian skills. ${ }^{15}$ The largest engineering operations carried out since the nineteenth century have been in the area of road and railroad construction. In 1965, four construction battalions were located in the South and four in the Northeast. Each one employed from 800 to 2,000 civilians in addition to the military personnel. It was pointed out to the authors that the military is often the easiest and quickest available federal agency that can act as a means of insuring the government's presence in remote areas and, for this reason, they have had an early start in the civicaction field.

In the area of vocational education, the army engineering institutes turn out nearly two hundred fifty engineers annually, most of them with an engineering degree. About four hundred enlisted men are given a six month technical training course and another two hundred, a six month advanced course. The navy and air force each have smaller vocational training programs. Although these numbers might not appear very large, they become 
significant when seen in perspective. For example, in 1961, the total number of engineers graduated from public and private institutions was 1,441 . Thus the army engineering institutions provide a significant percentage of the country's engineers.

The Guatemalan civic-action program is the most ambitious of the Central American programs. Most reports merely describe the projects, however, making an accurate quantitative survey impossible. The following will illustrate the five most important areas: road construction, school construction, school hot-lunch programs, literacy training, and mobile medical teams. ${ }^{10}$ In a period covering roughly 1964 and early 1965 about 32 kilometers of roads had been completed through dense jungle (bad weather had caused long delays), 16 kilometers had been improved, and 17 bridges had been constructed. In the school hot-lunch program, 301,498 children were served in 3,073 primary schools. The army's role in the program was primarily transportation of food and construction of warehouses (twenty-five reported). Literacy training brought 9,853 adult students to 503 centers during the period. In addition to this, the army was engaged in producing and printing primers for these and other literacy training programs. Only a few cases of school construction were reported, but this may or may not be indicative of the extent of the program. Mobile medical teams reported about 75,000 inoculations in various parts of the country as well as other types of medical treatment. A large number of small programs, conducted in co-ordination with local civic-action councils, continue as a matter of course and serve to improve relations with civil communities (e.g. painting of buildings and minor repairs to churches). 


\section{III}

\section{The Effect of Civic Action}

Where United States military missions have included a general evaluation of civic action in their reports to the Southern Command, they have usually advised that it has improved the image of the military. Although their criteria for evaluation are not always given, in most cases they mention only an increase in favorable publicity in the press. The United States civic-action officer in Argentina reported, for example, that "although it is early to determine accurately the extent of the effect of the overall program on public opinion, it is believed that the Civic Action effort in this country is being well received by the civilian population and that the image of the military has improved during this past year. ${ }^{17}$ The realization that both UsIA and United States military missions public information officers help to get civic-action items placed in the press-and urge the host government's military elements to be "public relations conscious"-tends to diminish the significance of this as evidence of "improvement of the military image."

The reports vary, of course, but there is a prominent feature in most of them that makes the reader suspect that the reporting officer's objectivity is clouded by his own enthusiasm. The rather laudatory descriptions of the long tradition of civic action in some countries make one wonder why the image of the military is not already highly favorable. And, although only a slight increase in civic-action projects is reported in some countries, we 
are often told that "the image of the military has improved during the past year."

The House Subcommittee on Inter-American Affairs also concluded during its hearings in 1965 "that the civic action program has improved the image of the military in Latin America by manifesting the interest of the military and the armed forces in the well-being of the people." 18 This unqualified conclusion of the subcommittee was based on a series of hearings in which the only evidence presented on this point was a statement by Lieutenant General Alva R. Fitch, deputy director, Defense Intelligence Agency. He noted that "the changes in the composition and attitudes of Latin American armed forces, often manifested publicly by beneficial civic action projects have in turn created increased public support and respect for the military in most countries." ${ }^{19}$ On the basis of this the subcommittee found that "the civic action program has improved the image of the military in Latin America." Apart from this rather cavalier use of the general's more cautious statement, it might be questioned whether the latter would be conclusive evidence even if he had been as categorical as were the findings that were based on his statement. No one at the hearings showed any apparent interest in the basis for his conclusion or raised any questions concerning it.

Experience in Bolivia, Peru, Ecuador, and Colombia suggests that civic action can act as a temporary deterrent of insurgency. Three points of clarification should be emphasized with respect to this statement. First, the evidence is suggestive rather than conclusive. Second, we say temporary in order to emphasize that the impact 
of any project is likely to be shortlived and likely to stimulate further demands for development and reform. Third, it has been in the more underdeveloped countries that these measures have apparently had the greatest impact.

In Peru and Ecuador, there have been cases where engineering battalions have moved into areas where scattered violence had previously erupted, and have managed to restore order. There are also signs of apparent success of Colombian civic action in the army's campaign against rural bandits. Another example cited to the authors was the influence of the presence of four engineering battalions on the Peasant Leagues in the northeast of Brazil. It was believed to be acting as a damper on the volatile political climate that is accentuated by a chronic drought problem and the extreme poverty of the masses. Virtually all United States military personnel in the various Latin American missions are of the opinion that these projects were helping to prevent insurgency. Civilian personnel tend to be less certain and divided in their evaluations. But there is very little concrete evidence to support the conclusions of these observers except for the lack of insurgency in the areas where impact-type projects are underway, a fact that they are often the first to admit may or may not be related to the projects.

One of the few field studies that has tried to ascertain the effects of specific projects came up with rather mixed conclusions. ${ }^{20}$ It was found that the program in Bolivia had engincered no particular gratitude on the part of the civilian beneficiaries. Most of the civilians intervicued expressed suspicion as to the army's mo- 
tives in engaging in civic-action projects, especially when it was working under contract. The study also found little evidence that the people feel any great gratitude toward the army for building a school. In fact, some people indicated suspicion as to the army's motives saying that they thought it was "making money." Some felt that their community could have done the job alone. Most of them did feel, however, that the army had changed for the better in recent years. The study also concluded that with skilful propaganda, the communities could easily be convinced of the value of civic action, especially since in most of the towns, the army's project was the only thing the residents could remember that the national government had ever done for them.

A United States civilian official with many years of experience has also expressed doubts:

The program has some value in educating the military to a sense of public purpose but it is costly education. It has less value in changing the public reputation of the military. It is too obvious a system of image-making. Sporadic offers of a medical clinic's services (e.g. once a fortnight) may make a garrison popular that day with those in pain. The intellectuals, or merely the intelligent, can't really believe they have a new model army just because there is talk of civic action and a few realities. The University is skeptical. I tried to have the civic action officers make a proposal to beautify (grade, landscape, etc.) the University grounds, and build some athletic fields. It did not come off. Something like this however, could do the job of sincerity.

Whatever the initial impression, it is unlikely that the good will created by amelioration of hardships will last long beyond the immediate impact of the project. Not 
only do people have a way of taking improvements for granted almost as quickly as they have been provided, but they become aware that further improvements are possible and ought to be forthcoming. Margaret Mead has explained one of the reasons for this attitude:

Where only the chief or the feudal lord lives in a large house and all other men in houses which are small and mean, the distinction is not between richness and poverty, but between privilege and absence of privilege in a system based on rank or caste or class. But when it is possible for a majority of the population to have some given thing - a tin roof, a well, a pump, inside plumbing, a donkey. -then the smaller number who cannot acquire it do not regard themselves, and are not regarded by others, as members of a different or lesser breed. Instead they come to feel, and others come to feel that they are simply poor. ${ }^{21}$

These observations are borne out by the record of the Betancourt administration in Venezuela. His administration brought the benefits of an ambitious program of public works to rural inhabitants who had been exploited for centuries. As well as producing gratitude on the part of the recipients, these efforts generated a demand for more of the same and protests that progress was too slow. Until recently, insurgency in Venezuela was primarily an urban problem rather than a rural one. There are three probable reasons for its transfer to the countryside: (1) The increased efficiency of the police in controlling riots and acts of terrorism in the urban areas, (2) the realization on the part of the insurgents that they would be unable to accomplish their objectives in the cities, and (3) the expectation on the part of insur- 
gent leaders that they could capitalize on growing discontent in the rural areas (ironically, as we have noted, a discontent abetted by the reforms already introduced).

On the other hand, most non-official observers (journalists, scholars, and businessmen ) are in agreement that the image of the armed forces has improved in Venezuela since the fall of Pérez Jiménez in 1958. To the extent that this is true, it could scarcely be the result of civic action. Only the FAC and the army have to any extent been involved in civic action and, as the report of a United States survey mission observed, "present Army emphasis is on long-range road building projects which have little immediate impact." projects are usually located in remote areas where they come to the attention of few people. It is far more probable that the military's image has improved as a result of its restraint in political involvement. The many complimentary references to this fact by government and party (including the opposition) leaders have brought it to the attention of the nation.

So far as the current problem of rural guerrilla activity is concerned, most military and civilian authorities are inclined to rely on the government's agrarian reform program and feel that the army's public relations should take the form of conducting its antiguerrilla operations properly. Furthermore, they argue, if there is discontent in rural areas and failure on the part of the local population to co-operate openly with the army, there is at the same time no indication of large-scale support for the guerrillas. Thus, although the guerrilla problem will continue to be a vexing one, the guerrillas will be unable to gain the mass support necessary to transform sporadic 
guerrilla activity into a mass movement capable of overthrowing the government.

In both Bolivia and Peru, civic-action programs have recently been associated with some measures of reform. In Bolivia the old army was destroyed in 1952 and a new one created that was more in sympathy with the aims of the National Revolution. This helped give credence to claims that the new army was no longer the servant of the tin barons and the oligarchy. Civic-action programs were also reinforced by a broad program of land, tax, and educational reform; and, in its search for resources, the MNR (Mrrimiento Nacional Revolucionario, National Revolutionary Movement) turned to the new army. Fortunately for the MNR, pro-MNR army officers were returning from exile and, like those who remained in the army after the 1952 purge, needed a raison d'etre for themselves and their institutions. Civic Action thus coincided with the interests of both the party and the armed forces.

In Peru, more than in most of the Latin American countries, the armed forces, especially the army, have had a tradition of civic action, especially in engineering. This has provided both a more favorable attitude and a capability upon which to build. After the military coup d'état that ousted the Prado government and annulled the elections of 1962, the armed forces found themselves directly responsible for the administration of the country. Facing a tense political situation, they were the more receptive to a role that would improve their public image. When Belaúnde was elected in 1963, he took pains to emphasize the virtues of the armed forces, and well he might. They had annulled the results of the previous 
elections where he had come out second to Haya de la Torre. Since taking office, Belaúnde has tried to utilize the armed forces as well as students and other groups in a program of national development and moderate reform. According to government sources, insurgency has not become a serious threat. But the part played by civic action can only be a matter of conjecture, and whether reforms are moving fast enough to discourage future insurgency remains to be seen. Furthermore, according to a New York Times report of June 25, 1965, the Peruvian minister of government "admitted the existence of communist guerrillas in central Peru."

Following nearly two decades of failure, Colombian military units have more recently been successful against rural bandits after employing the technique of civic action. By this means, the army has apparently succeeded in gaining the confidence of traditionally suspicious and often hostile campesinos to the point where they no longer co-operate with the bandits and in some cases even assist the army with valuable information. ${ }^{23}$ This is a significant accomplishment, and it has succeeded in bringing peace to at least some of the hitherto lawless areas of the country. But, unfortunately, it does not tell us much about the effectiveness of such measures against political insurgents. The bandits were, for the most part, individuals who terrorized the countryside for no other reason than robbery and a passion for killing. Under these circumstances they would hardly be very popular with the local inhabitants. ${ }^{24}$ The fact remains, however, that the peasants did protect the bandit by their silence in the face of military questioning until the advent of a directed civic-action program. 
In Guatemala, Nicaragua, and Honduras by virtue of the local propaganda and the extent of participation of the armed forces in civic-action projects, an impression is created of an all-out effort by an all-encompassing military establishment. In all three countries, the governments are essentially military-oriented. The Guatemalan president is Colonel Peralta and the Honduran president is Brigadier General Lopez. In Nicaragua, the current president, Dr. Rene Schick, is boxed in by members of the Somoza dynasty holding such positions as minister of foreign affairs and commander of the armed forces. The local military has a role in the administration or provision of rural police, in education, communications, transport, intelligence, and construction activities that provides a concentration of control in the influence of the Somoza family in many facets of the country s life.

Civic action in these three countries appears to be more a means of institutional (or dynastic in the case of Nicaragua) self-preservation than an attempt to get at the country"s fundamental economic and social problems. Building a few schools, roads, or other public works cannot for long mask the absurdity of meaningless and ineffective laws or decrees on land reform (usually proposing to turn over little-desired public lands to peasant families), tax reform, and bureaucratic corruption. As much as anything, the reason for the temporary peace prevailing in Guatemala and Honduras may be explained by the imprisonment or exile of difficult student, labor, and peasant leaders. But this is only treating the symptoms rather than the causes of insurgency and, at best, postponing the inevitable confrontation of problems. 


\section{IV}

As a part of the effort to improve the counterinsurgency capabilities of the Latin American Armed forces, the United States has tried to engage them in a variety of projects useful to civilians, especially in the rural areas. Although there has been little in the way of careful and objective evaluation of the effects of these projects (it is probably too early), we have noted some evidence that they are meeting limited objectives in a few of the Latin American countries.

The civic-action projects discussed above are desirable both from a humanitarian and a practical standpoint. Anything that adds to the material well-being of underprivileged rural inhabitants is a worthy endeavor. It seems unlikely, however, that civic action will play a crucial role in counterinsurgency in Latin America. It is as much a mistake to think that insurgency is merely a problem of poverty as to think that it is a problem posed by a few Communists. If meeting the threat of insurgency requires more than the development of military capabilities, it also involves more than a program of economic development and raising the standard of living. Furthermore, there are limits to which the Latin American military is willing to be converted, for professional considerations, from a sword into a plowshare.

Regardless of the type of government in power and whatever its programs, the development of social and political institutions capable of supporting that government is essential for long-range stability. The armed forces could play a crucial role in supporting a government while these processes are going on. But we have 
already observed that, in the past, the armed forces have often stepped in and stopped this process.

Where civic-action programs seem to be having a measure of success, it is because they are most relevant to the society in which they operate: (1) Where there is limited technical and administrative capability in the civilian sector, the contribution of the armed forces will be more visible by comparison and make a more favorable impact. (2) In the lesser developed country. almost anything that is done is a contribution of some significance and is visible as such. (3) The orientation of the armed forces themselves is important. Whether they are favorably disposed to civic-action programs has depended on a number of circumstances described in the preceding pages. (4) The rural orientation of civicaction programs in I,atin America would obviously make them more relevant to those societies where there is greater potential for rural insurgency. In the North Indean countries and in Central America, where large, exploited, and unintegrated Indian populations live in isolated mountain valleys, the potential for rural insurgency is the greatest. This may account for the greater receptivity to the idea of civic action shown by the armed forces in these countries. (5) In the longer run, success will depend on the extent to which the programs are tied to a broader program of social reform. If they are merely one of a number of means used to perpetuate a military regime whose main objective is the preservation of its institutional prerogatives or those of a small oligarchy, it is unlikely that even an ambitious program can indefinitely stem the tide of insurgency. The programs in Guatemala, Honduras, and Nicaragua seem to be of this orientation. 
A part of the theory behind civic action is that bringing the armed forces in as an integral part of programs of development and change will help to dispel their fear of change and of losing their dominant position in society. The experiment under way in Peru might in time shed some light on this. In Bolivia, one of the other countries in which the armed forces have shown a genuine interest in civic action, it quite obviously made no difference. In fact, General Barrientos, who headed the 1964 coup, had also been deeply involved in civic action. In El Salvador, where a reform-minded colonel is the president, the armed forces are now engaged only in scattered relief or good-will projects, ${ }^{2-5}$ with plans for expansion slowed by shortages of funds and skilled manpower.

Although there are no indications of an abandonment of civic action and other non-military means of preventing insurgency, there are indications that the Johnson administration is giving increasing attention to the more purely military solutions to the problem of counterinsurgency. There are, for example, signs of a revision of the Kennedy position with respect to military coups. The government placed in power by one such coup in Brazil in March, 1964, received "warmest good wishes" from President Johnson, and another coup in Bolivia later that year prompted no public statement of concern from the President or the State Department. There were also the much-debated and denied reports that, at a Washington meeting of United States ambassadors to Latin America early in 1964, the new assistant secretary of state for inter-American affairs urged that greater attention be paid to immediate national-security in- 
terests and a less passionate commitment to political freedom and social justice. ${ }^{26}$ We have already noted the decline in public and laudatory references to civic action eminating from presidential and State Department sources.

If it is true that military solutions are receiving more attention, the dilemma of such solutions was demonstrated by the fighting that broke out in the Dominican Republic in April, 1965. The situation that led the administration to order the landing of troops there may have emphasized the probability of similar situations in other countries. If fighting should break out, the local armed forces might be ranged on both sides and would be incapable of insuring that the outcome would be satisfactory to United States security interests. It is worth noting that it was another miliary solution to this dilemma that received sudden attention in 1965--the creation of an Inter-American Defense Force.

The United States Senate has, over a number of years, shown an interest in the subject of an inter-American military force. In 1959, for example, Senators Morse and Church introduced an amendment to pending legislation that would apply savings from reductions in military assistance for Latin America to an international military force under the control of the Organization of American States. ${ }^{27}$ Another amendment was offered by Senator Smathers expressing congressional support for the creation of a Western Hemisphere police force. In 1963, the Senate Committee on Foreign Relations approved a figure of $\$ 25$ million per annum to "be available during each fiscal year for assistance to an international military force under the control of the Organization of American 
States. ${ }^{28}$ The final legislative result of the 1959 and 1963 Senate discussions, however, differed significantly from the Foreign Relations Committee's recommendations. In 1959, no reference was made to the proposed defense force. In 1963, it was provided that "a part" of an authorized $\$ 55$ million "could be used during each fiscal year for assistance in implementing a feasible plan for regional defense." ${ }^{29}$

The invitation for the creation of an Inter-American Defense Force, suggested in various froms by Congress, appears not to have been advocated or pushed by either the State Department or the Pentagon. It is equally clear that the invitations did not meet with the approval of the Latin American governments. It was the Dominican revolt that brought an abrupt change. On May 6, the Tenth Meeting of Consultation of the American Ministers of Foreign Affairs approved a resolution sponsored by the United States and Latin American countries. It requested "governments of member states that are willing and capable of doing so to make contingents of their land, naval, air, or police forces available to the Organization of American States to form an Inter-American force that will operate under the authority of this Tenth Meeting of Consultation." ${ }^{30}$ Since that date, the President has, on a number of occasions, emphasized his interests in the establishment of a permanent inter-American defense force to meet situations similar to that in the Dominican Republic. In an address on May 28, 1965, President Johnson stated that

for the first time in the history of the Organization of American States [it] has created and it has sent to the 
soil of an American nation an international peace-keeping military force. That may be the greatest achievement of all. It is clear that we need new international machinery geared to meet the fast-moving events. When hours can decide the fate of generations, the moment of decision must become the moment of action. ${ }^{31}$

In a press conference held a few days later, the President expressed himself as "very delighted" that the interAmerican Force was functioning effectively. The observant reader will have noted that the meeting of Consultation of May, 1965, took pains to retain in its own hands the control of the Inter-American Force. There was no mention of the Inter-American Defense Board, or of its defense plans. This joint decision was entirely civilianoriented. This may also foreshadow a new trend.

We have already noted Senator Fulbright's amendment to the authorization bill for the fiscal year 1966 Foreign Assistance. The amendment authorized up to $\$ 25$ million for an Inter-American Defense Force under the control of the OAS. At a conference with the House of Representatives late in June, 1965, concurrence was obtained, with the stipulation that the costs of the current OAS forces under the command of Brazilian General Alvin would not be charged against the $\$ 25$ million authorization. The debate on new appropriation bills will offer another test of this proposed change in policy. In any event, another approach to the problem of containing insurgency and subversion has been made. The door is opened for new doctrinc and new procedures. The effect upon the doctrine and measures adduced in the early 1960 's may be to end a chapter and to begin a new one. 
1. Published in English as On Guerrilla Warfare (New York: Praeger, 1961). See also his "Guerrilla Warfare: A Means," Global Digest, I, No. 4 (January, 1964), 82-97 (trans. from Cuba socialista, September, 1963).

2. From the text of Nikita S. Khrushchev's report, "For New Victories of the World Communist Movement," January 6, 1961, at the Conference of Representatives of Communist and Workers Parties held at Moscow in November, 1960.

3. A Compilation of Materials Relating to United States Defense Policies in 1962, House Doc. No. 155, 88th Cong., 1st Sess. (1963), No. 22-750, p. 164 (emphasis added).

4. Walter Darnell Jacobs, "This Matter of Counterinsurgency," Military Rezicz, XLIV (October, 1964), 79-83.

5. See, in general, Harry Eckstein (ed.), Intcrnal War (New York: Free Press, 1964), and, in particular, Lucien Pye's chapter, "The Roots of Insurgency," pp. 157-79. The latter observes (pp. 178-79) that "it is extremely difficult to provide governments with sound and useful devices on how to deal with a threat of insurgency. Our initial observations of the irrelevance of most such advice have been borne out by our subsequent analysis." See also David Galula, Counter Insurgency Warfare: Theory and Practice (New York: Praeger, 1964); Felix Gross, The Scizure of Political Power in a Century of Revolutions (New York: Philosophical Library, 1958), and Neil J. Smelser, Theory of Collective Behaviour (New York: Free Press, 1963).

6. These assumptions may also be noted in a number of articles and books on the subject of civic action: Colonel Robert B. Rigg, "Twilight War," Military Revicu', November, 1960, pp. 28-32; Colonel Robert H. Slover "Civil Affairs in the Area of Cold War," Congressional Record, CVII (June 27, 1961), A4857-58; also in United States Army War College Selected Readings, Course 4, 1962-63 Curriculum, U.S. Global Strategic Concepts and Military Capabilities, Phase II, Counterinsurgcncy; Lieutenant-Colonel Harry F. Walterhouse, "Civic Action: A Counter and Cure for Insurgency," Military Rerierc', August, 1962, pp. 47-54; Chalmers A. Johnson, "Civilian Loyalties and Guerrilla Conflict," World Politics, XIV, No. 7 (1962), 646-61 ; Frank A. Lindsay, "Unconventional Warfare," Foreign Affairs, XL, No. 2 (1952), 264-74; Alvin H. Scaff, "The Army with a Social Conscience" and "The Land of Promise," chaps. ii and iii of The Philippines' Anszier to Communism (Stanford: Stanford University Press, 1955) pp. 25-48; Harry F. Walterhouse, A Time to Build: 
Military Civic Action, Medium for Economic Development and Social Reform (Columbia, S.C.: University of South Carolina Press, 1964), p. 9-36, 80-111; and John S. Pustay, Counter-Insurgency Warjare (New York: Free Press, 1965), pp. 141-50.

7. The term "impact project" is difficult to define. (The Joint Chiefs of Staff dictionary does not attempt to do so.) Much depends on the context in which such a project is defined, and, for that reason, a variety of definitions are usually implied rather than stated explicitly. We suggest that an "impact project" as the name implies is one designed especially to produce rapidly a favorable impression on local inhabitants. It would usually be a project that is certain of completion within a relatively short period with clearly discernable benefits to a maximum of local inhabitants and answering a need of which the local inhabitants have been aware.

8. United States Southern Command, Quarry Heights, Canal Zone, Civic Action Projects Reports 1 March 1964-1 January 1965, March 11,1965 , pp. 5 ff., 287 ff.

9. Ibid., pp. $177 \mathrm{ff}$.

10. A survey of the United States Army mobile training team, Civic Action in Venezuela, 45-MTT, 03-64, May 8, 1964, p. 3, also noted that "by comparison with the resources of the civilian sector those of the military are rather small. Road-building provides a good example. Venezuela has excellent roads in its more populated areas and has adequate civilian resources for building roads in remote areas. The road-building capabilities of the Army Engineer units are, by comparison, very limited."

11. Pages $17 \mathrm{ff} ., 87 \mathrm{ff} ., 291 \mathrm{ff}$. See also Alfredo Ovando Candia, Las fuerzas armadas de Bolivia en acción civica (La Paz, 1964), and J. S. Goitia, Civic Action: Role of the Armed Forces in the Social and Economic Development of a Country (La Paz: Centro Audio Visual, USAID, 1964).

12. United States Southern Command, Civic Action Project Reports, pp. $141 \mathrm{ff} ., 417 \mathrm{ff}$.

13. Ibid., pp. 85 ff., 217 ff., 373 ff.

14. Ibid., pp. $65 \mathrm{ff} ., 209 \mathrm{ff} ., 349 \mathrm{ff}$. "Department of Defense Intelligence Report," No. 28190130 64, OUSARMA Colombia (Unclassified); Alliance for Progress Newsletter, USIS-USAID (Bogotá, Colombia, August 24, 1963); Colombia, Fuerzas Militares, Ejército Nacional, Celebración del dia del Arma de Ingenieros: Exposición (Bogotá, October, 1964); Alberto Ruiz Novoa, "La acción cívica 
militar en Colombia," Ponencia del General Alberto Ruiz Novoa, Ministro de Guerra, en el Primer Congreso Latinoamericano de Es. cuelas Radiofónicas, mimeo. (September, 1963).

15. United States Southern Command, Civic Action Projects Reports, pp. $35 \mathrm{ff} ., 335 \mathrm{ff}$.

16. Ibid., pp. 99 ff., 259 ff., 387 ff.; Lieutenant Colonel Anthony J. Auletta, "Ten-Nation Progress Report," Army, July, 1963, pp. 53-54; Walterhouse, $A$ Time to Build, pp. $99 \mathrm{ff}$.

17. Covering letter from United States, Civic Action Officer, Argentina, to Commander, United States Air Forces Southern Command, Albrook Air Force Base, January 1, 1965.

18. Subcommittee on Inter-American Affairs of the House Committee on Foreign Affairs, Communism in Latin America, Report by the Honorable Armistead I. Selden, et al. 89th Cong., 1st Sess. (1965), p. 13.

19. Subcommittee on Inter-American Affairs of the House Committee on Foreign Affairs, Hearings, 89th Cong., 1st Sess. (1965), p. 9.

20. Paper prepared by William H. Brill, April 1, 1964 (unpublished).

21. Margaret Mead, "The Underdeveloped and the Overdeveloped," Foreign Affairs, XLI, No. 1 (1962), 80.

22. United States Army Mobile Training Team, Survey of Civic Action in Venezuela, 46-MTT, 03-64, mimeo., May, 1964, p. 4.

23. Lieutenant Colonel Keith C. Nusbaum, "Bandidos!", Army Review, XLIII, No. 7 (July, 1963), 20-25.

24. Robert C. Williamson, "Toward a Theory of Political Violence: The Case of Rural Colombia," Western Political Quarterly, XVIII, No. 1 (March, 1965), 35-44; German Guzman, Orlando Fals Borda, and Eduardo Umana Luna La violencia en Colombia (Bogotá: National University, 1962), especially chaps. v-vii. Recent press reports refer to Communist participation in some areas but have not claimed that Communists are a major factor.

25. United States Southern Command, Cizic Action Projects Report, pp. $91 \mathrm{ff}$., $253 \mathrm{ff}$., $381 \mathrm{ff}$. For a full account of the reform policies of President (Colonel) Julio Riveras' government, see Murat W. Wiiliams, "The Alliance for Progress," Foreign Service Journal, XLII, No. 6 (June, 1965), 25 ff.; and Lieuwen, op. cit., pp. 91-94.

26. Edwin Lieuwen, Generals vs. Presidents: Neo-militarism in Latin America, pp. 142 ff.; Rowland Evans and Robert Novak, "Inside 
Report," Washington Post, March 31, 1964, and March 21, 1964 ; and the Necv York Times, March 22, 1964.

27. Minority Views of Senator Morse, Sen. Rept. No. 412 on S. 1451, Mutual Security Act of 1959, 86th Cong., 1st Sess. (June 23, 1959), Part II, p. 1.

28. Senate Committee on Foreign Relations, Sen. Rept. 588 on H.R. 7885, 88th Cong., 1st Sess. (October 22, 1963), p. 23.

29. Public Law 88-205, Foreign Assistance Act of 1963, 88th Cong. (December 16, 1963), H.R. 7885.

30. Doc. 39 (English) Rev. Corr. (May 6, 1963), Original : Spanish. For the texts of the resolutions adopted at the Tenth Meeting of Consultation as of June 2, 1965, see Appendix I.

31. Commencement address at Baylor University, Waco, Texas, May 28, 1965, as reported in the New York Times, May 29, 1965. 



\section{Chapter 7}

\section{Armies for Progress?}

With the 1960's came a new emphasis on the problems of internal security in Latin American countries. This new emphasis was accompanied by a doubling of the amount of United States military assistance granted. Was there a connection? It would be difficult to establish a direct relationship, but this much can be said: The emphasis upon internal security made it easier to persuade Congress to authorize additional expenditures for assistance because the role of the Latin American armed forces in internal security is a more plausible one and has been articulated in popular terms. From the United States side, the amount still looks small compared with total foreign aid and military assistance, and it can be appropriated with little trouble. The argument used is that training and equipment is necessary in order for the military to be able to preserve order and prevent a Communist take-over while the difficult task of reform and transition is being carried 
out. From the Latin American side it is a different matter. In some countries the amounts of MAP are of real significance. And, as we have noted, recent military coups in Brazil, Bolivia, and the Dominican Republic do not give cause for optimism concerning the role that the military are ready to play.

The military assistance program also brought increased contact between United States and Latin American military personnel. The contacts were supposed to have a beneficial effect on the social and political views of the Latin American officers. Secretary of Defense Robert McNamara assured a Senate subcommittee in that regard that "the experience we have had indicates that the exposure of the military officers to our schools acquaints them with democratic philosophies and democratic ways of thinking which they, in turn, take back to their countries." 1 But evidence offered to support Mr. McNamara's contention is scarce and of doubtful validity. It usually consists of statements by Latin American officers trained in the United States declaring their beliefs that the military should stay out of politics. Whether they held these views before they received training in the United States is not usually considered. Furthermore, there are examples of United States-trained officers who have participated in military coups against constitutional government.

In the instance of the Santo Domingo affair of May, 1965, leading military figures on both sides of the dispute, including Colonel Caamaño, Colonel Wessin y Wessin, and Colonel Imbert, had received training at one or more United States military schools. Perhaps an outstanding example of this was the ousting of President Prado in Lima in July, 1960, a fortnight before 
his constitutional term would have expired. Colonel Gonzalo Briceño, who arrested the president in the $\mathrm{Na}$ tional Palace, was trained at the Ranger School at Fort Benning, Georgia, later returning to Peru to develop an antiguerrilla commando unit. His breaching of the palace gates was accomplished by a Sherman tank, furnished by MAP. The members of the military junta included Major General Lindley López, who attended the General Command and Staff College at Fort Leavenworth, and Major General Vargas Prada, a graduate both of Fort Leavenworth and the Armored Tank School at Fort Knox. Other members of the Peruvian junta's cabinet had studied at the Fleet Sonar School in Key West, Randolph Field, Texas, and the Engineering School at Fort Belvoir. One member of the junta, Rear Admiral Torres Matos had received the United States Legion of Merit from Secretary of Defense Gates in the Eisenhower administration; another member, Major General Lindley López, received the same decoration in 1961, from Secretary McNamara in the Kennedy administration. ${ }^{2}$

There is another possible result of contacts between United States and Latin American military personnel that has only recently begun to receive attention. Unconfirmed reports regarding Argentina, Brazil, Ecuador, Bolivia, and the Dominican Republic have charged that United States military personnel by word or deed had an influence upon the action of the local military in time of political crisis. This may not always have been consonant with the policy followed by the State Department and the embassy.

Spokesmen for the deposed Paz regime in Bolivia charged that United States military attachés were secretly supporting the rebels, while the ambassador was 
supporting the constitutional government. ${ }^{3}$ An editorial in the New Republic charged that "in Honduras, while U.S. Ambassador Burrows fought to prevent the overthrow of President Villeda Morales, members of the U.S. military mission there openly supported the coup." + Another report that Ambassador Burrows had his MAAG and mission officers caution the Honduran coup leaders against their rumored moves suggests that the ambassador might have had some doubt concerning the attitudes of his own officers or the Honduran officers' concept of what those attitudes might be. ${ }^{.}$From Bolivia, there were also reports of a United States Colonel who was "visiting old friends in Bolivia on his way to Chile" in June, 1965. These friends reportedly included the top members of the ruling junta who immediately dispatched a mission to Washington to negotiate new financing for rehabilitation of the tin mines. According to New York Times reporter Henry Raymont, Bolivian officials had hinted that the Defense Department appreciated the urgency of the situation more than the embassy had." Relations of this nature emphasize to the local military the political involvement of United States military officers who are supposed to be setting examples for their Latin American counterparts. If the United States military were to enter into local politics in the sense of influencing national decisions-a course of action which is a constant temptation-it would be engaging in an activity that is opposite of its intended goal: indoctrinating the local military to stay out of political intrigue.

Perhaps this illustrates a gap in the authority and strength of the State Department and embassy control over the interference by United States military in the conduct of United States foreign policy and diplomacy. 
It is not suggested that a United States military attaché or MAAG officer was directed by the Joint Chiefs of Staff or by the Unified Command at Quarry Heights, to discuss and influence political decisions within a Latin American country. Such actions are more likely the spontaneous and personal responsibility of the individual officer concerned. But the authority and responsibility for making comments and giving advice or warnings as to the consequences of political decisions or actions in a Latin American country, which are given by an embassy, derive from decisions reached at Washington, where they represent a consensus of military, economic, political, and other considerations that are taken into account there and transmitted to the embassy in instructions from the Department of State. For an individual United States military officer to tender his own advice or counsel, then, is for him to place his own ideas against those of his government. The obvious irresponsible character of such counsel, and the implications of divergence from his own government's policy, unfortunately does not prevent such private endeavors from taking place.

It is also possible that negotiations directed from Washington may not contradict embassy policy but might, nevertheless, emphasize the importance and prestige of the military (United States and Latin American). In Honduras, when reports of the impending 1963 coup reached Washington, a United States major general was sent to inform the Honduran officers of the President's opposition to such moves. ${ }^{\top}$ Action of this nature only serves to point out to the Latin American military that the United States recognized them as a government within a government. 
There appears to be another consequence of the affinity between the United States military and their Latin American counterparts. Frequently, the Latin American requests for military equipment are, despite their inappropriateness, endorsed and forwarded by the maAg's the Unified Command, and the Pentagon without challenge (normally in that chain of command there is no qualified economist). The projects and the costs are more likely to be challenged only by the Bureau of Budget, AID (which has a goal of long-range economic development), or by congressmen in appropriation hearings. Especially when projects are challenged by the congressional committee members, the military spokesmen on occasion take refuge in general statements, security classification, and references to the fast rotation in duty stations, thus allowing the spokesman to avoid discussion of past events on the grounds that he was then charged with different responsibilities. In view of the basic differences and incongruities between the background, technical and professional training, and sociological orientation of the North and South American officers, the logical reason for the affinity is hard to ascertain. It leads to the surmise that the basis is no other than that of comrades in arms.

\section{II}

\section{Civic Action in Perspective}

What do the recently emphasized civic-action programs add to this picture? There is agreement among nearly all of the United States Military officers and many civilian officers in the field that the civic-action pro- 
grams are adding to the ability of the armed forces to meet the threat of insurgency, largely by improving their image among the rural inhabitants.

Although these beliefs remain for the most part untested and not without some doubts, they are based upon reasonable assumptions and some concrete evidence that would justify a continuation of the programs. One of the strongest arguments in support of civic action, therefore, is that it is a temporary means of preventing insurgency. We have suggested, however, that a distinction must be made between those countries where the programs seem to have little relevance to the society in which they operate and others where the programs are more relevant. In the first category, we have listed Argentina, Uruguay, Mexico, Venezuela, and Costa Rica. Among the countries where the programs appear to be more relevant are the North Andean countries (except Venezuela) and the Central American countries (except Costa Rica). Inasmuch as civic action can at best be a temporary measure with reference to the problem of insurgency, it will soon outlive its usefulness unless the respective governments tackle the long-range problems of social reform and economic development. In this respect, the military governments of Guatemala, Honduras, and Nicaragua, among the Central American governments, do not offer much cause for optimism. Indeed, the ever-widening scope of civicaction jurisdiction in those countries appears to have served-intentionally on the host government's part-to build up and to consolidate the existing military regimes. Where the government and the military are one and indivisible, it can only be expected that the techniques supplied by Fort Bragg, Fort Gordon, and Fort Gulick will be used to perpetuate such regimes. Professor Dana 
Munro, for many years in active contact with the daily relationships between the United States and Caribbean countries and a life long observer of that area, concludes that earlier United States military training gave their armed forces "a potential power which only the ablest of the old style caudillos had." ${ }^{8}$ Herbert Matthews' phrase is "we put political power in the hands of the military and made them invincible." 9

What of the argument that civic action is contributing to the economic development of Latin American countries and, therefore, to the solution of the long-range problem that we have referred to? Assuming that the military is not to be involved primarily in political and social reforms necessary for economic development, the role of the military in development should lie in its contribution to infrastructure.

In a developmental situation, it is not the case that just any public works would further economic development. Resources are scarce, and it is important that the building of infrastructure follow a rational time sequence and pattern. There should be some concern that the military activities be balanced against priorities established by the country planners. Do the civic-action projects fit into the national plan? Is the administration of the program co-ordinated with either national or local civilian government agencies? Is there a national plan into which the projects can be fitted? Are there regional and local plans? Generally, the answer to these questions is "no."

Infrastructure is taken to mean those "social capital" or "social overhead" requirements for the functioning of a modern economy. An Alliance for Progress report divides infrastructure into two categories: economic and social. Included in the economic category are power, 
communications, and transportation projects. In the social category are health, water-supply, sewage, housing, and community development programs. ${ }^{10}$ It is important to note that the creation of infrastructure is intended to have a long-run and modernizing impact on the society. That is, a dam, a highway, or a sewerage system has an expectation of being in use for a number of years. A less concrete, but equally vital, long-run influence would be the role of education. A modern educational system might change attitudes for all time. It might mean that the society could never return to the cultural patterns of the past that inhibited economic growth. The long-run, modernizing role of infrastructure, then, is to be distinguished from other programs that perhaps leave the people better off in some sense but do not play a role in modernization. For example, the distribution of surplus food or clothing or occasional medical treatments make life somewhat easier to bear, but these activities do not provide self-education or talents to sustain economic growth in a developing economy. These activities should be more properly called welfare programs. As we shall suggest later, a large part of civic action falls into the category of welfare rather than infrastructure.

A provision in the Foreign Assistance Act of 1961 implied that the military could make a contribution to economic development: " to the extent feasible and consistent with the other purposes of this part, the use of military forces in lesser developed, friendly countries in the construction of public works and other activities helpful to economic development shall be encouraged." This formulation of policy implies a priori that the military can make a contribution to economic development. Although it may be self-evident that certain "public 


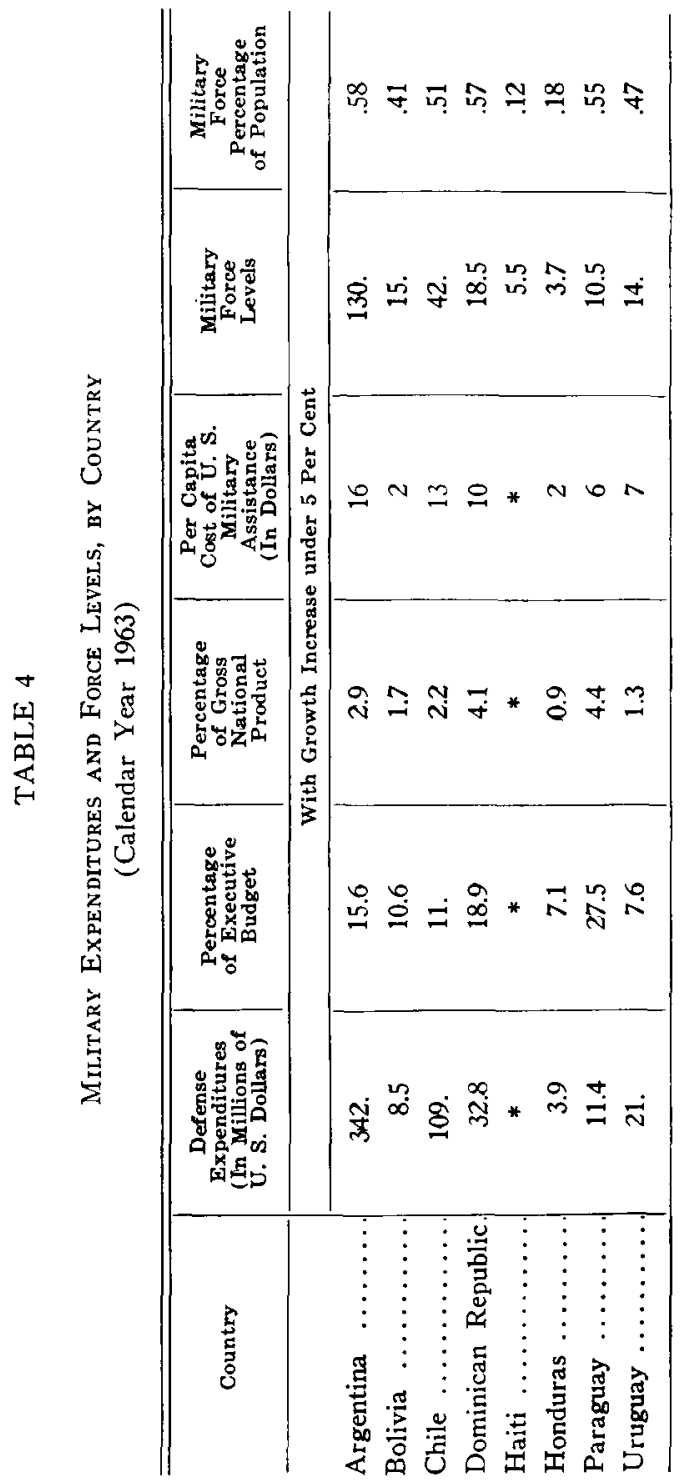




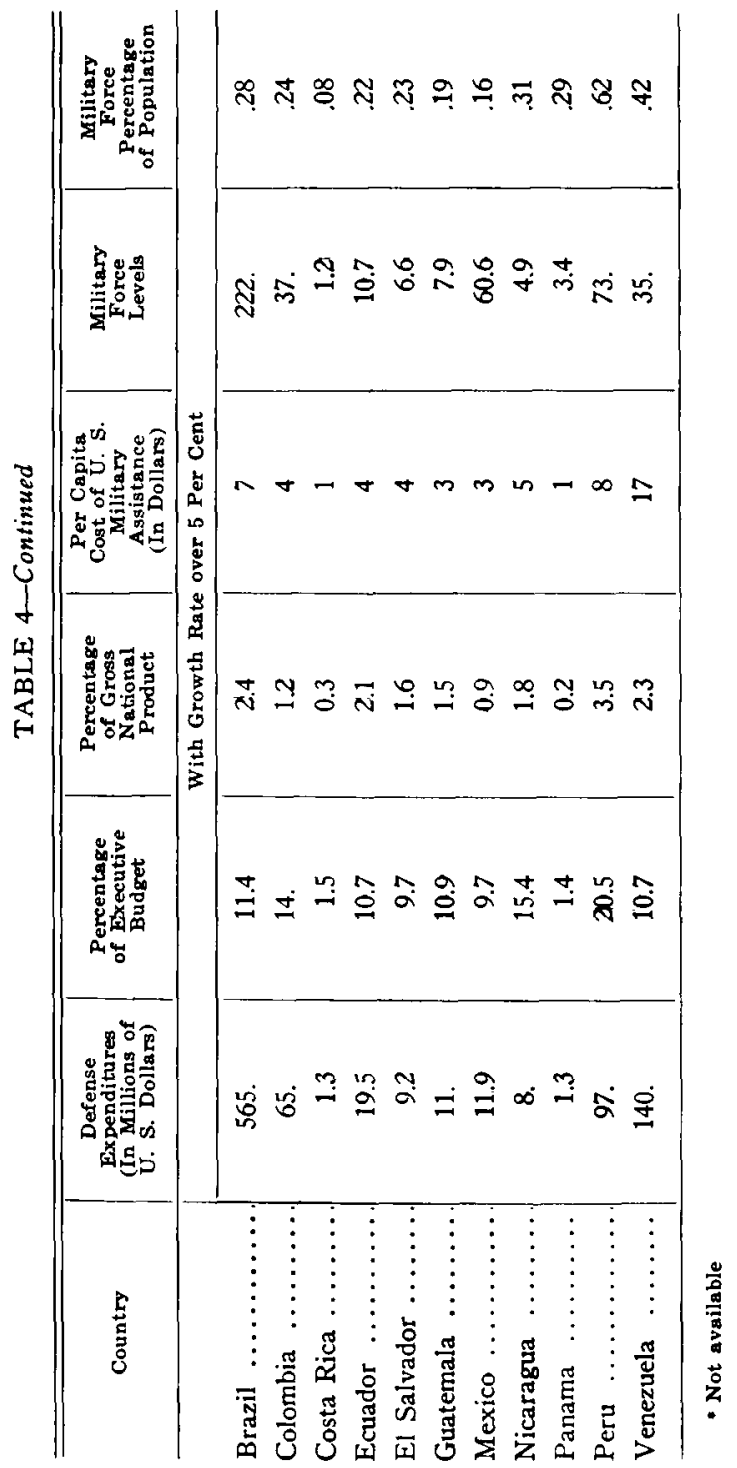


works" help economic development, what are the specific public works contemplated by the United States Congress? What are some of the "other activities helpful to economic development"? Are there other economic or political conditions that may affect the military's ability to carry out economic development?

From official sources have emanated catalogues of "activities helpful" to economic development. But beyond some generalizations about the use of engineering battalions for building roads and draining swamps, the need for sanitation and medical care, and the usefulness of military training and education, there is little theoretical framework from which to judge these activities in the context of economic development. Are each of these activities equally important to economic development? Or are some functions of military civic action more related to a simple concern for human welfare? For example, the Ecuadorian Army initiated a project in the port city of Guayaquil to haul potable water for the use of people in the crowded slums of the city until such time as adequate water storage facilities could be constructed. ${ }^{11}$ The army quartermaster in Guatemala City supplied food to twenty-six stores and markets in the slum area of the city at reduced prices to alleviate the suffering there. ${ }^{12}$ Much of the medical work done by military units is of the same character.

In order to maximize the psychological and political effects, the programs are selected for high-impact value:

The most successful programs are those which produce fast, tangible and visibly beneficial results. Such projects are road construction to remote areas providing farmto-market travel, school construction and maintenance, 
literary training, school hot lunch programs, medical and health programs, and youth camps. The least successful projects are those which produce no immediate results. ${ }^{13}$

Although all civic-action projects are expected to brighten the image of the military, some are more directly aimed at this goal than are others. The Colombian Army has organized a band, for instance, to tour rural areas of the country, and the Paraguayan military provides bands for concerts and dances. In Guatemala, the army stages Christmas parties for children in hospitals, donates shoes to poor children, and provides free haircuts for needy civilians. Military units of El Salvador in their "Operation Niño," drop candy and gifts on rural villages by parachute to demonstrate their Christmas spirit. "The Army Hour," is the Guatemalan military's radio gift to the people. ${ }^{14}$

This kind of civic action has seemed especially attractive to Latin American military units, which, it has been said, suffer no end of mental anguish about their generally low standing with the people. Public-relations activities are designed to correct all of that and to change the image of the military in the nation's eye "from an oppressive arm of the national government into that of an agency actively assisting in the economic and social development of the country." 15

Replies to congressional questions and articles in military reviews often state that civic action makes "a contribution" or even "a valuable contribution" to the economic development of Iatin America. General Andrew P O'Meara, commander in chief, United States Southern Command, stated that "in addition to achiev- 
ing the objective of enabling the military to gain the confidence of the populace, and winning them away from the subversive revolutionaries, the money makes a distinct contribution to the economic development of the area and is thus a definite contribution to the goals of the Alliance for Progress." ${ }^{16}$ Undoubtedly, a case can be be made that civic-action programs are making "a contribution." Almost any bridge, road, or school will probably be of some benefit to the economy. But the more important question is how much of a contribution and at what cost. Few, if any, ask these questions (except for the cost in terms of dollars). Neither in congressional testimony nor in unclassified military reports is evidence to be found of the size or the importance of the contribution made.

A rough indication of the extent of the contribution that civic action is making to the economic development of particular countries and of Latin America as a whole could be provided by making two types of comparisons. The first of these would place the more concrete and measurable data on civic action against the total national effort in particular categories. For example, if (as President Belaúnde of Peru has announced as a goal) the Peruvian armed forces will be doing one-half of the road construction in Peru, this gives a rough estimate of the contribution of civic action in that country. In Bolivia, the school construction program whereby most of the schools constructed since 1962 have been (and reportedly will continue to be) constructed by the army gives another rough estimate of contribution. All of this, of course, requires some knowledge of the total governmental effort in any given category. If, for example, school construction is virtually brought to a halt, con- 
tributing a large share of such a contribution is not a very notable achievement. Similarly, the contribution of the Argentine armed forces (see page 124) does not seem very significant in a country with a defense budget of $\$ 342$ million, 130,000 in service (in 1963) and a United States assistance program amounting to $\$ 9.3$ million.

In making a second type of comparison, rough estimates such as this can be used as a means to demonstrate certain countries in which the military's contribution to economic development is more important (and to give a rough idea of how much more important). We propose that the two categories of countries suggested with respect to counterinsurgency provide a first step (see page 223). These distinctions are important because, although the appropriations for civic action are based upon recommendations and requests for specific countries, in congressional hearings they are usually discussed for "Latin America." Thus a useful program in Peru or Bolivia might be cited in support of a budget that includes assistance to several other countries where the programs may be making little or no contribution to national development.

Furthermore, civic action has not been and cannot be uniform in purpose, concept, administration, organization, or results in Latin America. It should not be set up as a blue print to be applied to each country. Room must be left for local variations, flexibility of operation, and even different objectives and purposes in different countries; obviously this means differences in procedures, administrative practices, and the choice of projects. By the same token, it is more than obvious that the tactics and methods employed in Korea, Malaya, or Vietnam 
are rarely applicable to the Latin American atmosphere and tradition. Unfortunately, there has been a tendency in some quarters to apply the Asiatic experience to Latin America, where it was not pertinent or relevant. The Philippines, Korea, and Vietnam are new countries with a recent colonial past and with war-torn political and economic handicaps not duplicated in Latin American republics. The latter have enjoyed 140 years of national independence, many of them with no significant combat experience or war damage during that period and no strong close Communist enemy to threaten them.

There is another reason to make distinctions from one country to another. The functions usually described in glowing terms as the activities and even the successes of military civic action, both in the United States reports and in the published accounts within Latin America, have usually fallen under the headings of construction projects for roads, schools, and wells; sanitation and health projects; and literacy. These functions have in the past been discharged by civilian agencies and ministries. In many of the countries they can be better accomplished by these agencies at present and in the future. It is self-defeating to establish government air lines to remote parts of the country on the basis of there being no previously existing commercial service. For the consequence of that would be that the need being filled by government facilities there would be no incentive for private or commercial initiative, and years would go by with no increase in commercial air facilities. Ministries of government, education, agriculture, colonization, health and sanitation, forests and labor could also perform these functions without the creation of additional bureaucracies or expense. The consequence might very 
likely be to improve the strength of the civilian economy and the civilian elements in society to withstand military take-over.

Always to be taken into account, when attempting an assessment of the value of military civic action, is the not insignificant consideration that through military civic action thousands of man-hours are utilized in a more useful and economically beneficial way with psychological by-products of public spiritedness, participation in community development, or even a sense of satisfaction derived from sharing in a national effort.

With respect to political development, what is unique about civic action is that it allegedly prepares military men to participate actively in civil affairs, not as in earlier United States-sponsored programs to encourage professionalism. And it is on that point that the case for military reform appears to rest. Such participation, it is suggested, will engender mutual respect and trust between civilians and the military, encourage habits of co-operation, and promote a common dedication to the interests of the nation. ${ }^{17}$ The reported results of civicaction programs in this respect are thus far anecdotal and of little help in making a general evaluation. They do, however, show some obstacles against which civicaction planners must work. First, much depends on the outlook, interests, and ability of individual Latin American officers who are in charge of the projects. Some will be concerned only with the immediate goal of completing an assigned project without displaying any interests in other goals such as community participation and organization.

Second, generally speaking, the military in Latin Imerican countries have lacked the political skills that 
would permit it to operate successfully in civilian areas. By the very nature of its command structure, the military profession is not a good training ground for the techniques and processes of negotiation and bargaining, highly important for political leadership. Although it lacks these capabilities, the military in Latin America normally possesses more of those specialized skills and resources suitable for completing a project in the shortest possible time. It is, in short, well prepared to undertake the kind of programs that are, in fact, emphasized in civic action.

Third, the efforts of civic-action officers appear to be minimal in obtaining the collaboration of the local population; and when there is active co-operation, it is primarily for the immediate and temporary purposes of accomplishing the project at hand. Thus, a ready supply of manual labor is obtained, and a convenient channel of communication established by co-operating with local leaders. A civilian administrator of the military civicaction program, for example, found it very useful to generate a spirit of competition in an Ecuadorian project where the military worked from one end building a road, and local civilians worked separately from the other end. That this approach to the projects is widespread is indicated from a recent Defense Department study:

All too frequently the good things that civic action attempts to bring to peasant communities are being thrust upon the people almost willy-nilly. Even such effective and useful things as malaria eradication . construction programs, improved wells, better road systems, if they are not generated with and through the community 
involving large numbers of people the total effect of the civic action may well be psychologically counterproductive with respect to the feelings and attitudes of the peasant population. At worst, such types of imposed civic action can positively alienate the populations on which they are forced, and at best such top-down, outside-in penetration can result in populations coming to passively accept and expect services from government and militiry without a concomitant self-help effort.

By 1964, some of the practical difficulties in the conduct of civic action were reported in a brochure entitled "Military Civic Action" prepared by the Department of the Army. The brochure listed "problems" that confront civic action within a foreign country: personal ambitions, bureaucratic jealousies, "pork barrel" tendencies, inaction by host-country military personnel, and the public's reactions. Also noted were the causes of troubles within the United States government that were obstacles to the army; i.e., shortages of personnel trained in either civic-action doctrine or in the technical skills needed, long delays in obtaining equipment, and other frustrations. A detailed statement of the "problems" is found in Appendix H. A highly respected United States military officer after observing civic-action arrangements in a number of Latin American countries found among the Inited States officers a surprising amount of apathy and indifference and, in some instances, even ignorance of the standing instructions and manuals of procedure so laboriously and hopefully prepared and sent out from Washington headquarters. It is clear that the personnel assignments, training, individual initiative, strong leadership within the MAAG, and harmony in the Country Team need to be in first-class order to achieve first-class results. 


\section{III}

\section{The Future of Civic Action}

There is no indication that the execution of military civic-action programs in Latin America is likely to become too large or get out of hand. At the same time it should be realized that military civic action should not be used as an argument to assist and to rationalize the granting of more authority to the military. It is one thing to encourage the Latin American military to engage in civic action as a means of putting an existing military establishment to better use than has been the case in the past. In general, if it means tractors instead of tanks, encouragement of civic action could be justified even if there are doubts as to whether the military is the best and most economical agency to conduct such operations. But if we insist that civic action must not detract from military capabilities-and the United States Congress has made this stipulation, with the United States military's concurrence-then civic action is likely to mean tractors in addition to tanks. Thus there is the danger that civic action, like "an attack on the hemisphere, "standardization of weapons," or "Communist subversion threats" will become but another cliché accepted uncritically in the rush to support increased military programs for Latin America.

The data reveal that the yearly average of United States military assistance to Latin America in the decade of the 1950's was $\$ 35$ million. But for the years 1960 to 1965 , the annual average is no less than $\$ 70$ million, 
which is double the previous average amount. The sharp increase after 1960 may be noted in the figures below: This is evidence that, in fact, civic action has been in addition to other military expenditures.

\section{TABLE 5*}

United States Military Aid to Latin America, 1952-61

\begin{tabular}{|c|c|}
\hline $\begin{array}{l}\text { Fiscal } \\
\text { Year }\end{array}$ & $\begin{array}{c}\text { Amount } \\
\text { (In Dollars) }\end{array}$ \\
\hline 1952 & . $\quad 200,000$ \\
\hline 1953 & $\ldots 11,200,000$ \\
\hline 1954 & $. .34,500,000$ \\
\hline 1955 & $. .31,800,000$ \\
\hline 1956 & $\ldots 30,400,000$ \\
\hline 1957 & $\ldots 43,900,000$ \\
\hline 1958 & $\ldots 47,900,000$ \\
\hline 1959 & $. .54,000,000$ \\
\hline 1960 & $\ldots 53,700,000$ \\
\hline 1961 & $\ldots 91,600,000$ \\
\hline
\end{tabular}

*Source: Remarks by Senator Gruening in Senate debate, August 21, 1962, reported in Congressional Record, p. 14414.

The small size of the civic-action fraction of military assistance to Latin America, as shown in Tables 6 and 7 and as careful and persistent perusal of the congressional hearing reveals, has been under-emphasized. The budget figures in the tables following help to put the program for Latin America as a whole into perspective. Table 6 presents the proposed United States 1965 civic-action program. The amount is small relative to the gigantic one billion dollars and more annual Military Assistance Program expenditures in recent years. The approximately ten million dollars allocated to Latin America for fiscal 
year 1965 comprises only 1 per cent of the Military Assistance Program budget and .3 per cent of the total foreign-aid program. It is clear that the civic-action program must be evaluated in the light of a very limited allocation of funds. Described elsewhere is the arrangement for joint funding of the program by the Agency for International Development (AID) and the Military Assistance Program (MAP). MAP provides the equipment and most of the advisers, while AID furnishes consumable items, such as cement and gasoline.

\section{TABLE $6 *$}

Proposed Program for United States Military Assistance for Civic Action to Latin America for the Fiscal Year 1965 (In Thousands of Dollars)

Argentina $\$ 1,206$

Bolivia

Brazil 2,314

Chile 1,096

Colombia 1,124

Costa Rica

Ecuador

El Salvador

Guatemala

Panama

Paraguay

Peru

Uruguay

Venezuela 
TABLE 7*

AID ANd MAP Crvic Action, 1962-64

(In Thousands of Dollars)

\begin{tabular}{|c|c|c|c|c|c|c|}
\hline \multirow{2}{*}{ COUNTRY } & \multicolumn{2}{|c|}{$\underset{1962}{\text { FISCAL YEAR }}$} & \multicolumn{2}{|c|}{$\underset{1963}{\text { FISCAL Y EAR }}$} & \multicolumn{2}{|c|}{$\underset{1964}{\text { FISCAL YEAR }}$} \\
\hline & AID & MAP & AID & MAP & AID & MAP \\
\hline Argentina ..... & & & & & & 302 \\
\hline Bolivia $\ldots \ldots \ldots \ldots$ & 1,700 & & 1,990 & 1,817 & 1,062 & 530 \\
\hline Brazil ...... & 300 & 2,220 & 1,207 & 2,156 & & 2,442 \\
\hline Chile $\ldots \ldots \ldots \ldots \ldots$ & 200 & 860 & 283 & 2,019 & 187 & 1,483 \\
\hline Colombia .......... & & & 698 & 1,488 & 698 & 1,578 \\
\hline Costa Rica . & & & & & & 247 \\
\hline Dominican Republic . & & & 451 & 596 & 233 & 64 \\
\hline Ecuador ........... & 700 & 1,500 & 160 & 323 & 273 & 657 \\
\hline El Salvador ......... & & & 100 & 534 & & 216 \\
\hline Guatemala .......... & & & 325 & 863 & 80 & 809 \\
\hline Haiti ............. & & & & & & \\
\hline Honduras .......... & 100 & & 103 & 84 & & 21 \\
\hline Jamaica ....... & & & & & & \\
\hline Mexico ........ & & & & & & \\
\hline Nicaragua..... & & & & 59 & & \\
\hline Panama .... & & & & & & 2 \\
\hline Paraguay ... & 200 & & 2,130 & 840 & & 1,402 \\
\hline Peru ......... & 100 & 1,135 & 162 & 2,794 & 260 & 791 \\
\hline Uruguay $\ldots \ldots \ldots \ldots$ & & & & 546 & & 453 \\
\hline Venezuela ..... & & & & & & 23 \\
\hline Total & 3,300 & 5,715 & 7,609 & 14,119 & 2,793 & 11,021 \\
\hline
\end{tabular}

* Source: Interview, November, 1964, with an officer of the Internationa! Security Affairs Section of the Office of the Assistant Secretary of Defense.

Much of the Pentagon and State Department testimony is about the tactics and the putative advantages 
of civic action. But the funds appropriated for Latin American military assistance are spent largely for heavy war equipment and supplies. The acceptance of the concept of civic action is stretched to cover a great deal of military hardware. In 1964, Secretary of Defense McNamara testified before the House Committee on Foreign Affairs that 15 per cent of the $\$ 66.2$ million military assistance program for Latin America would go for civic action. That would amount to less than $\$ 10$ million for operations in twenty countries (Jamaica is included in Pentagon plans) - an average of $\$ 500,000$ per country in that one year.

In recent years, the Military Assistance Program has been presented to the congressional committees, under the heading "Alliance for Progress Security." The use of the catch-words "Alliance for Progress" as an umbrella under which to shield the appropriations requests, which increase each year, is perhaps an understandable gambit for the executive departments to use in their dealings with Congress. But the relationship to the alliance of the major expenditures under MAP is a distant one. Moreover, as noted, those expenditures for civic-action projects, which can and may ultimately contribute to alliance goals, account for only 15 per cent of the total. Furthermore, in presenting MAP requests for Latin America, Pentagon representatives are prone to refer to "internal security" purposes. This might, to the uninitiated, seem to correspond to civic action. A close reading of the testimony and of the requests reveals that under the heading "internal security," the Pentagon classifies such expenditures as those incurred for patrol boats, equipment and training 
for airborne military units, transport aircraft, communications equipment, and related items. This is despite the relative importance and time devoted in appropriations hearings to the objectives and benefits of civic action.

Civic action may even be justified on its own merits and in certain countries in addition to other military expenditures, but the more important point is that it should not be used as window dressing for other regular military expenditures. Those who are convinced that civic action is a worthwhile program that should be encouraged, no less than those who might choose to use it for window dressing, might be tempted to claim all things for civic action, especially in answer to congressional questioning. But those who are convinced of the value of the program might in the long run do better to emphasize that civic action by the military has been only a small fragment of the United States program within the hemisphere as a whole or within any individual country. It will presumably continue to be only a fraction of the program. There is no evidence in the middle 1960's of the repeated urgency by the White House or aggressive follow-up by the attorncy general in the now infrequent meetings of the Special Group. It might be safe to assay the current efforts and civic action as routine and even declining in official favor, compared with 1960-63. Therefore, not too much should be expected of it. It cannot remake the countries; military civic action, as the most constructive element of the broaler coined concept, would be only one minor aspect of such a purpose.

A danger in "overselling" the program is that, when it does not produce the miracle likely to be expected of 
it, it may be abandoned. In this respect, we have noted a change of emphasis in the Johnson administration. Without abandoning or even reducing expenditures for civic action, there are signs of an increasing reliance on military solutions to hemispheric defense and threats of Communist subversion, while, at the same time, the Kennedy policy of giving all-out moral and economic support to the so-called democratic governments has been dropped. (The realities of political life, the paucity of policy alternatives submitted to voters, the weakness of political parties, the lack of an independent judiciary, and the limitations on the freedom of press and civil rights make the use of the adjective "democratic" a comparative one at best. This is not to disparage the diplomatic protocol under which it is accepted usage to refer to Latin American governments as "members of the democratic Free World," but, in fact, some have military rulers, some have civilian dictators, and others have few of the characteristics of government and society that could, in any objective use of the term, be considered democratic.)

Within Washington, there is evidence to indicate that there was a rapid rise in the prestige and favor with which military civic-action projects met in the period 1960-63. Previously there had been mixed views within different United States government agencies; some civilians were favorably inclined, but some were opposed to them as dangerous additions to the already overwhelming influence of the Latin American military. Some military advocated civic action. Perhaps for purposes of re-establishing their own branch or service to a more prominent place, some military were opposed to military 
civic action on the theory that the energies expanded for these purposes were only subtracted from the normal defense capability of the local military. After civic action became popular, there was a period when there were recriminations and blame assigned to one or another agency for having delayed or limited the military civicaction program. In 1963-65 there has been much less public urgency displayed regarding civic action. Messages to Congress have been much less frequent or strongly stated than was the case in 1961-63. In reference to the Latin American area, in a dozen policy speeches delivered by $\mathrm{Mr}$. Mann during his tenure in 1964 as assistant secretary of state for inter-American affairs and United States Co-ordinator of the Alliance for Progress, no mention is made of any aspect of military civic action. President Johnson has mentioned the subject but not with emphasis or priority. The projections of hopeful results to be anticipated from civic action are normally made by Secretaries Rusk and McNamara in connection with appeals to Congress for funds.

The retreat of United States policy in hard pressed countries, such as Vietnam, from a policy which emphasized military civic action to overcome subversion and insurgency to greater reliance on conventional military strength and modern weapons, such as jet bombers, could be an indication that strategic and security thinking in Washington no longer relies on "winning the hearts and minds of men" to contain guerrillas or discourage potential insurgents. Somewhat similar would be the consequence of the experience in Santo Domingo where it soon became clear to all that armed force was going to play the determining role. 
At the beginning of this volume, we pointed out that a dilemma is contained in the related objectives of promoting security and reform in Latin America. Strengthening the military was advocated by the United States as a means of providing the internal stability necessary for sustained economic growth and social reform. Yet strengthening the armed forces might help to perpetuate military dictatorships in some countries and to overthrow reform-minded civilian governments in others. Civic action was seen as a means of bringing the Latin American military into line with the objectives expressed in the Alliance for Progress. There is no undisputed proof of the success of civic action, but the same must be said for the Alliance.

1. Senate Committee on Foreign Relations, Hearings, Foreign Assistance Act of 1962, 87th Cong., 2d Sess. (April 5-18, 1962), p. 76.

2. Congressional Record, August 2, 1962, p. 14416.

3. New York Times, November 22, 1964, and June 4, 1965.

4. November 2, 1963, pp. $13 \mathrm{ff}$.

5. Edwin Lieuwen, Generals vs. Prosidents: Neo-militarism in Latin America (New York: Praeger, 1964), p. 119.

6. New Fork Times, June 4, 1965.

7. Lieuwen, Generals vs. Presidents, p. 7.

8. Dana G. Munro, Intcricntion and Dollar Diplomacy in the Caribbean, 1900-1921 (Princeton University Press), p. 540.

9. Herbert Matthews, "Diplomatic Relations," in The United States and Latin America, ed. Herbert Matthews (Englewood Cliffs, N.J.: Prentice-Hall, 1963), p. 126.

10. Alliance for Progress: Its Second Year, 1962-1963 (WashingIon, D.C.: Pan American Union, 1964), p. 13.

11. Headquarters, United States Southern Command, Panama Canal Zone, Press Release, July, 1964. 
12. Civic Action Progress Report, United States Military Group, Guatemala, to United States Southern Command, Panama Canal Zone, January 11, 1965.

13. Letter to the authors from Brigadier General George L. Mabry. Jr., Quarry Heights, Canal Zone, January 18, 1965.

14. Taken from Civic Action Progress Report from Guatemala to United Southern Command, Panama Canal Zone.

15. Report on Civic Action in Ecuador, AID, October, 1963.

16. Statement of General Andrew P. O'Meara, United States Army, commander in chief, United States Southern Command, House Committee on Foreign Affairs, Hearings, Foreign Assistance Act of 1964, 88th Cong., 2d Sess. (April 14, 1964), H.R. 10502, pp. 401-2.

17. General Wood, testimony, House Committee on Foreign Affairs, Hearings, Foreign Assistance Act of 1964 (April 16-22, 1964), Part IV, pp. 563-66 and p. 531. 

Appendixes 



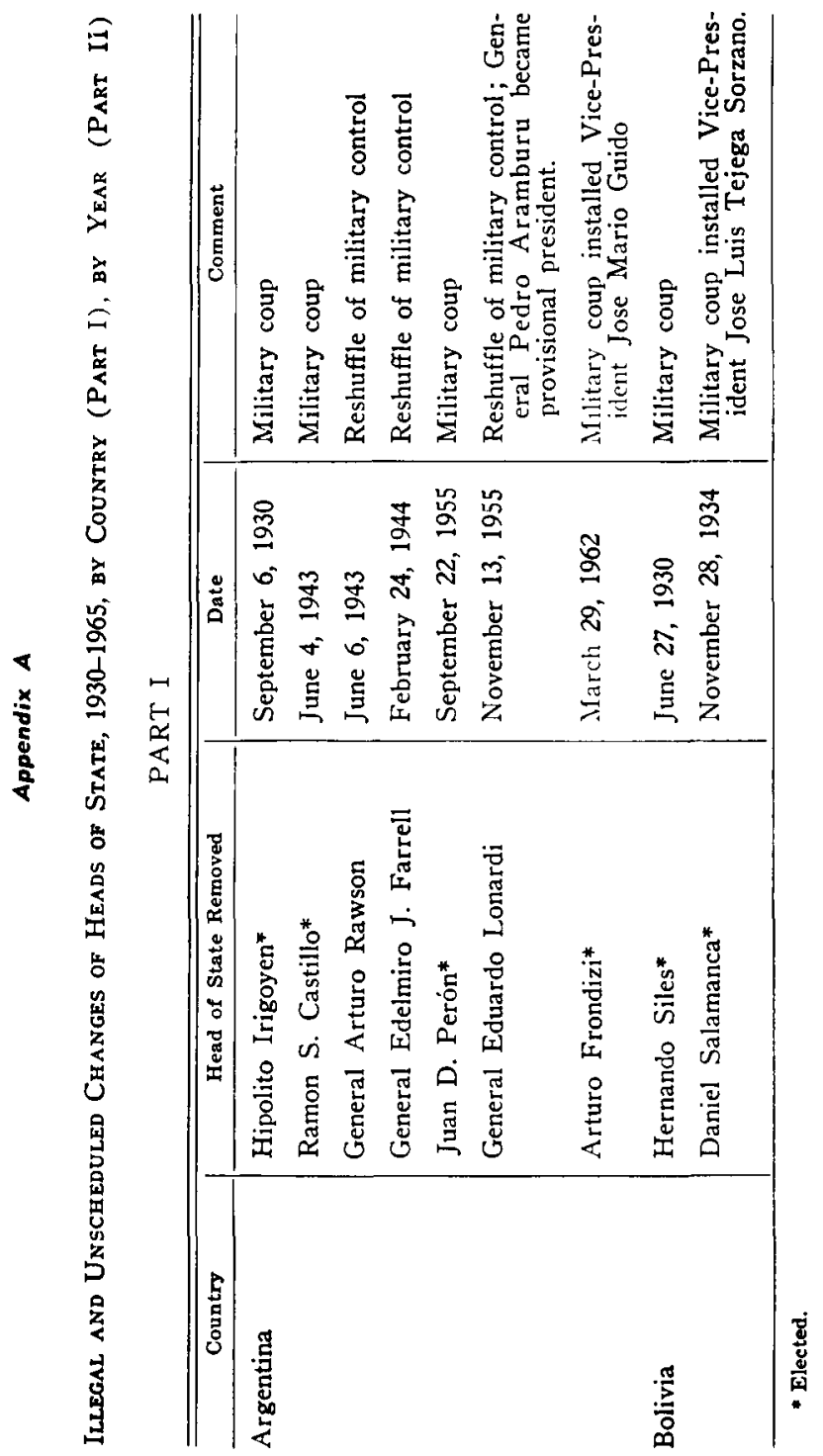




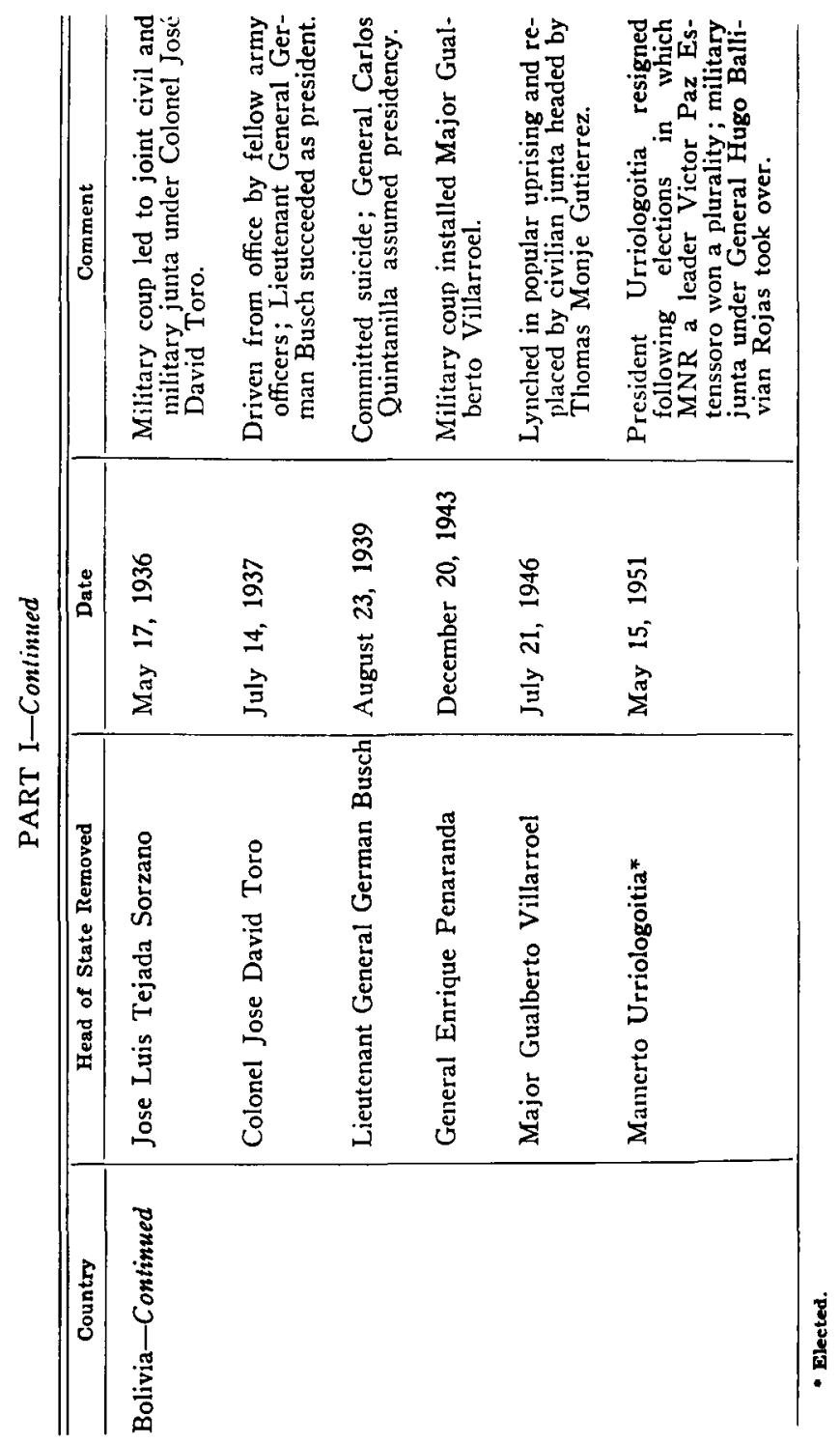




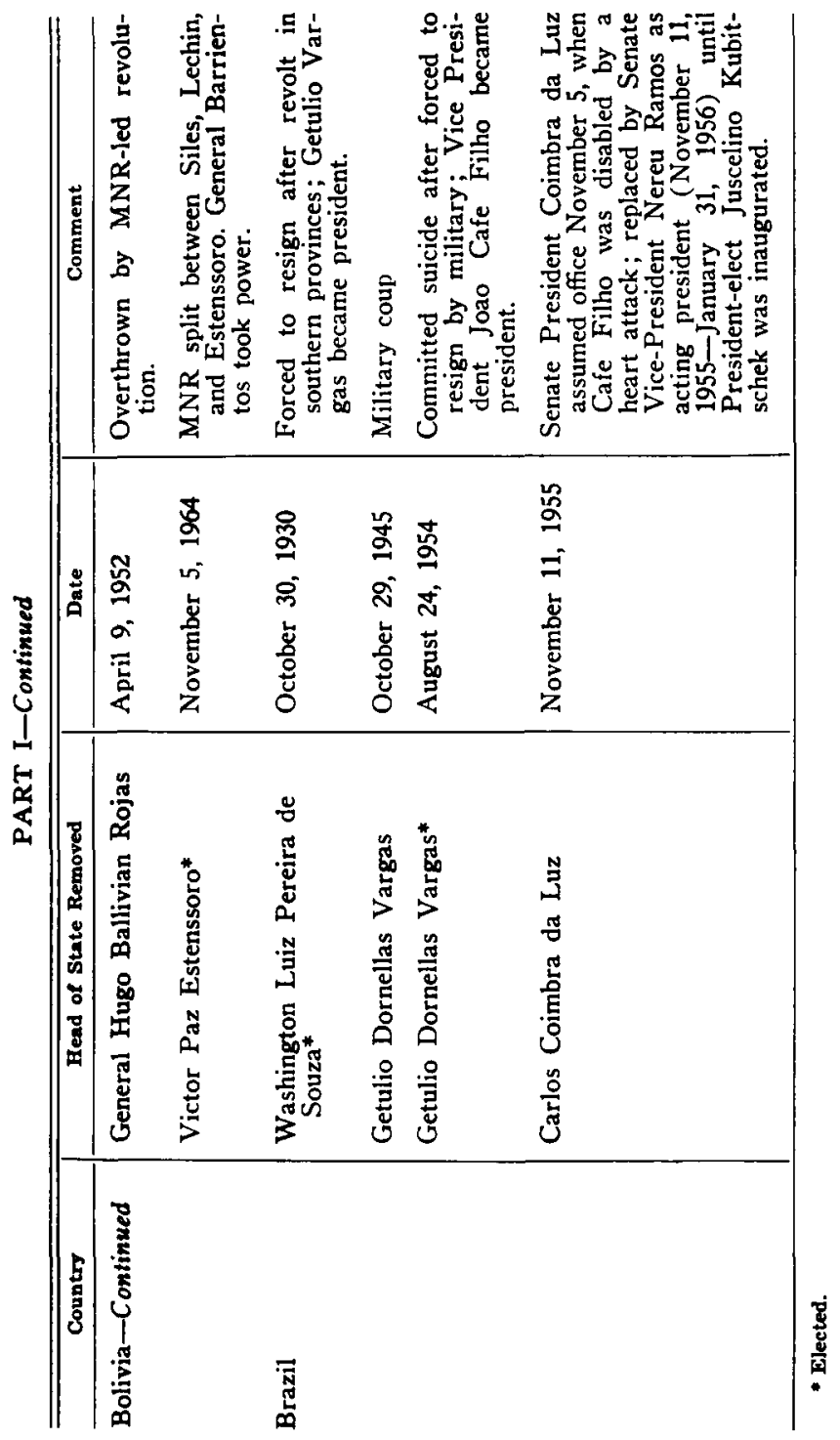




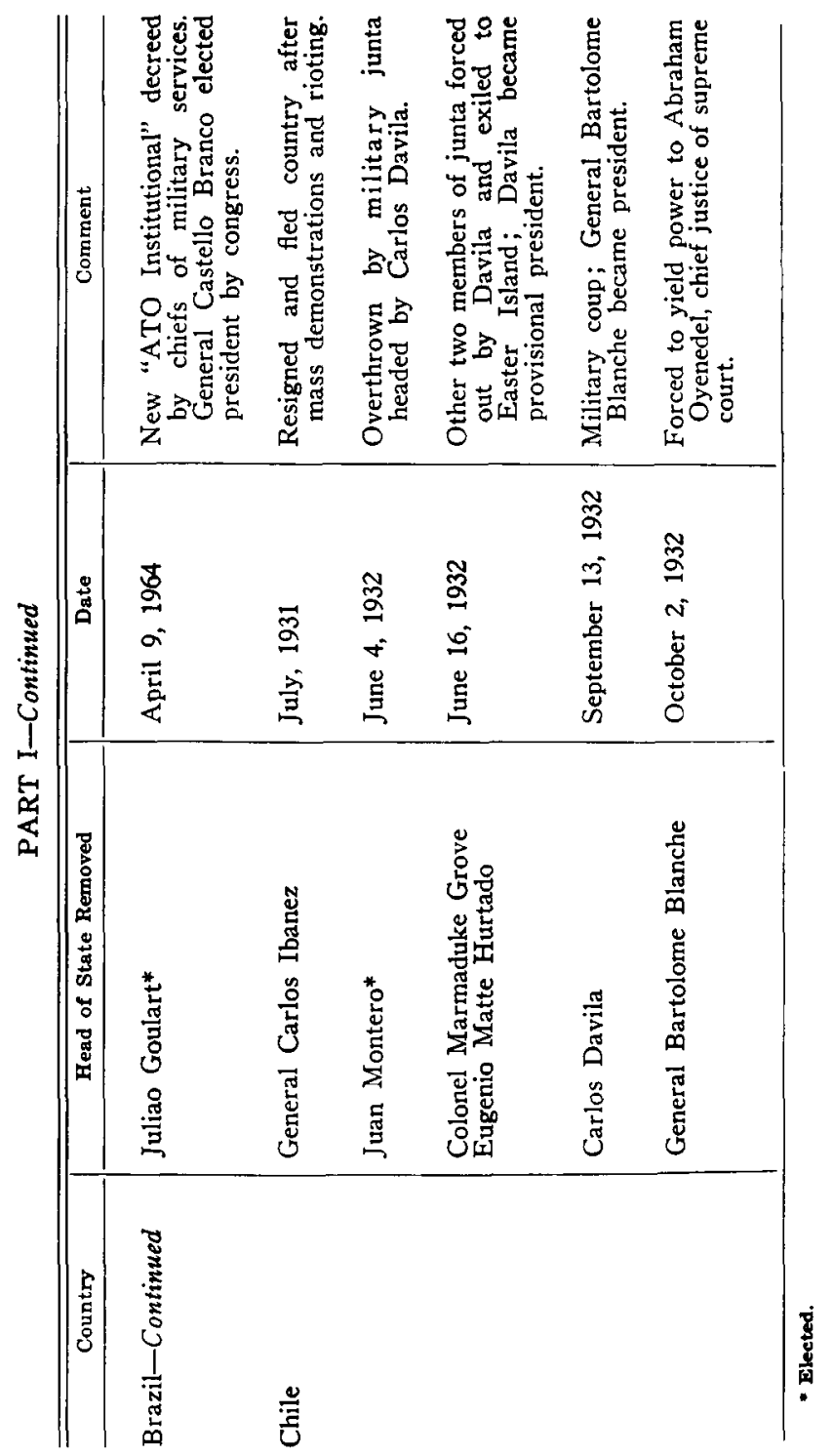




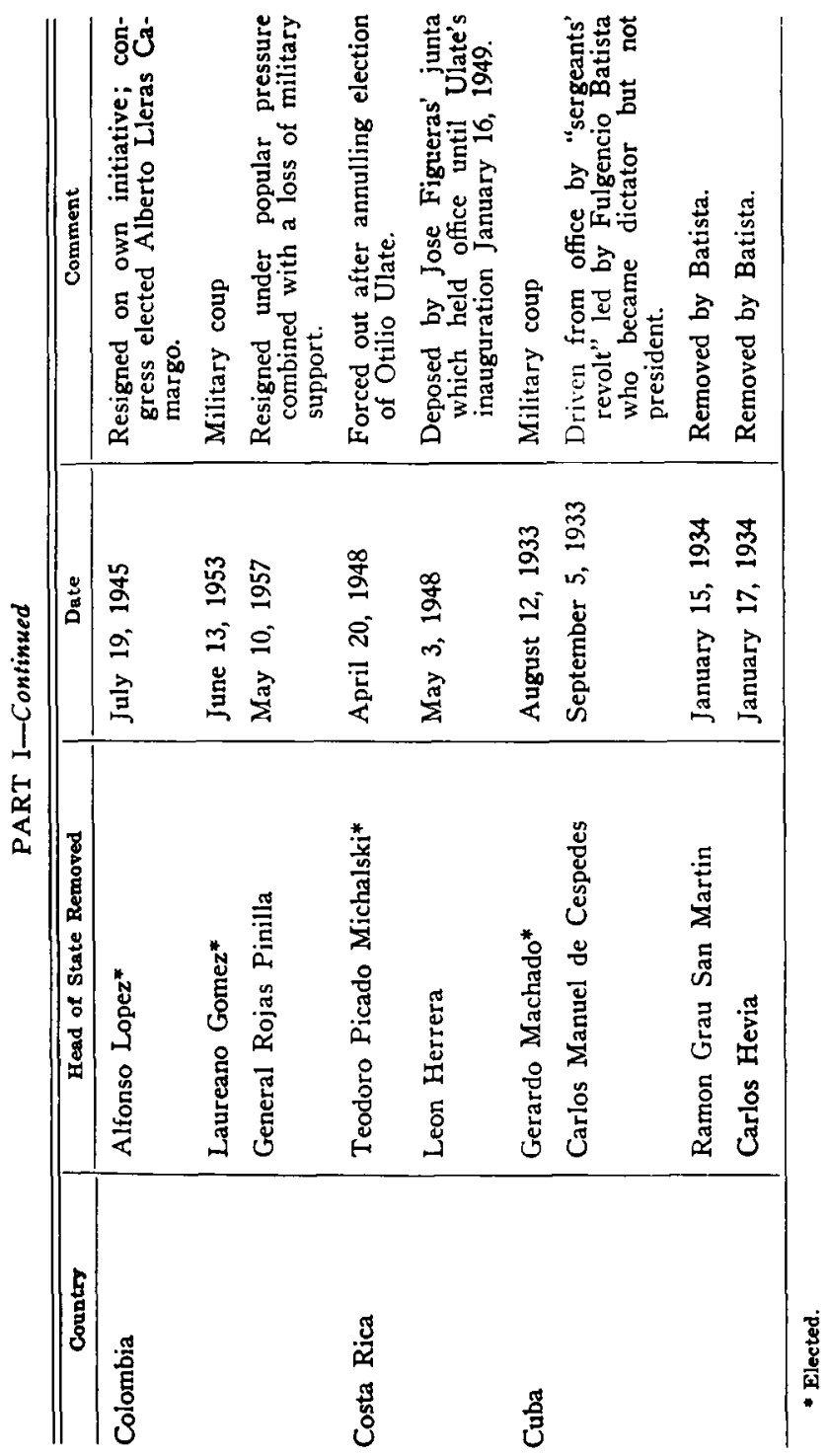




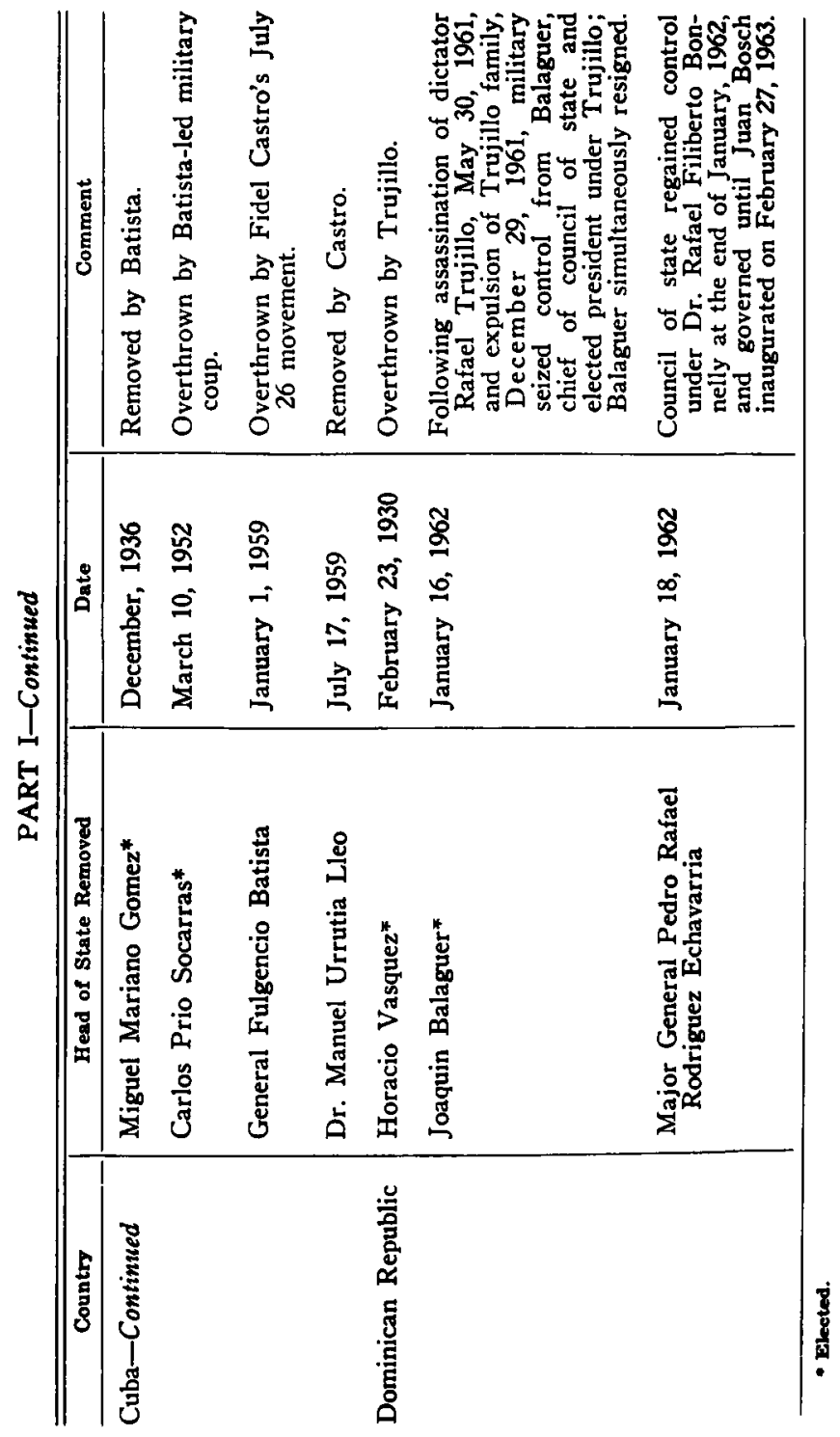




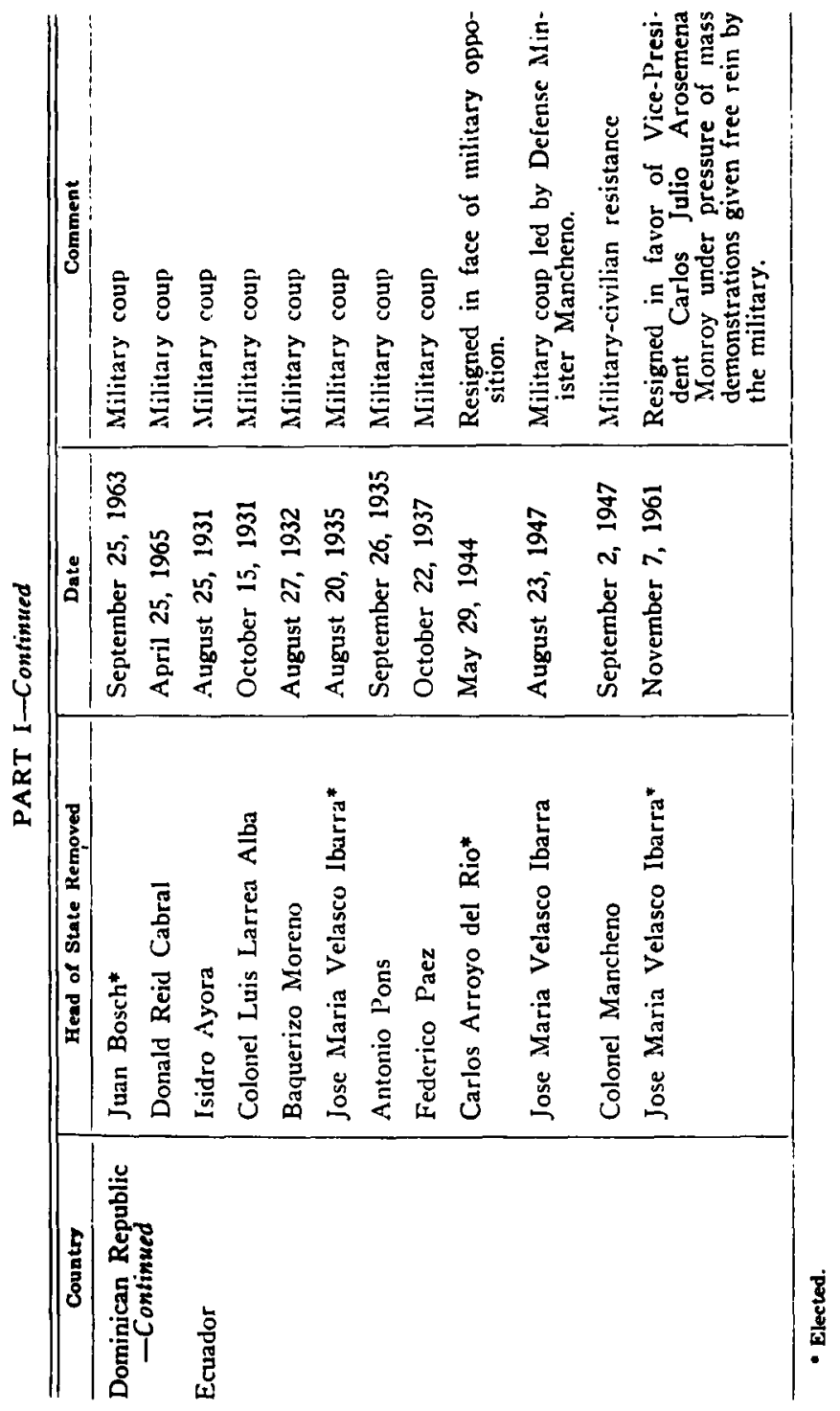




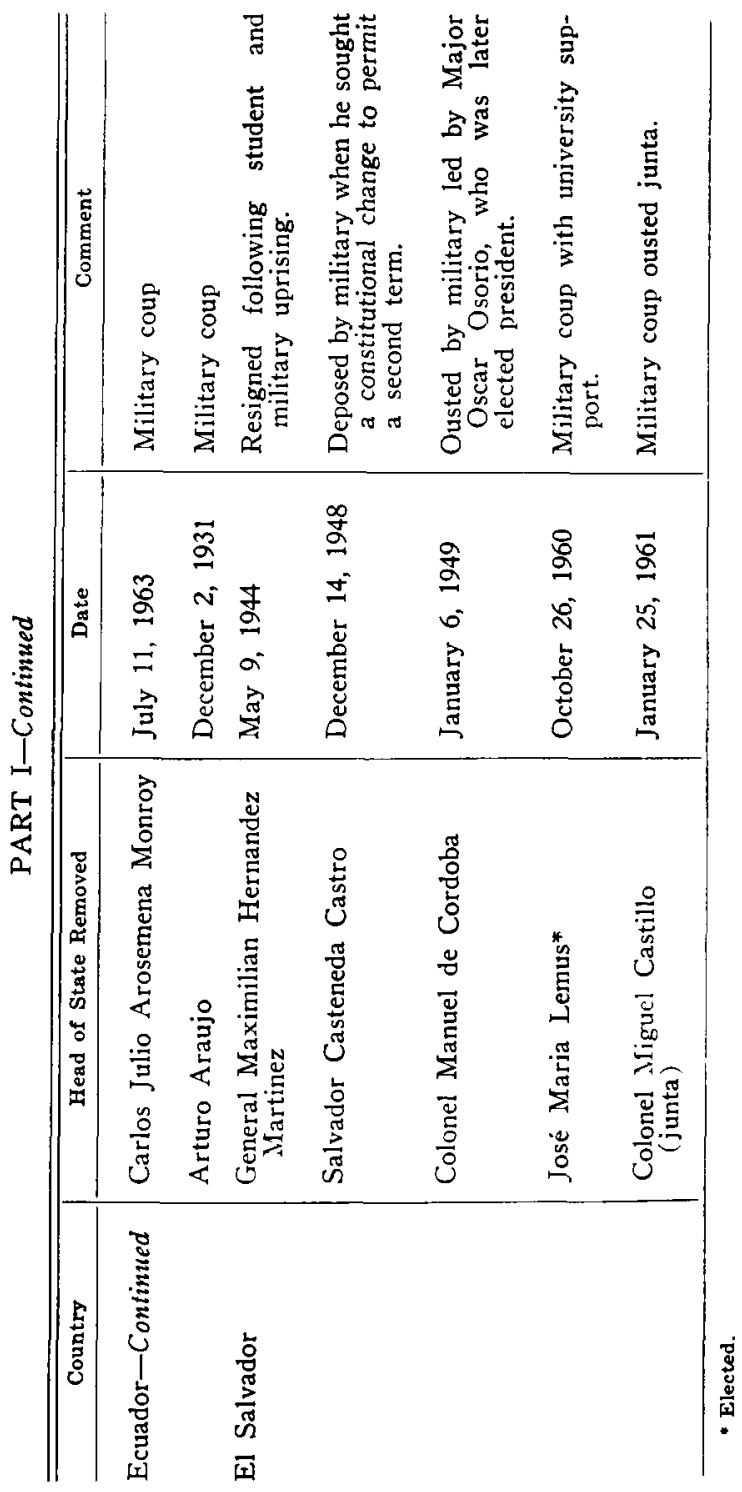




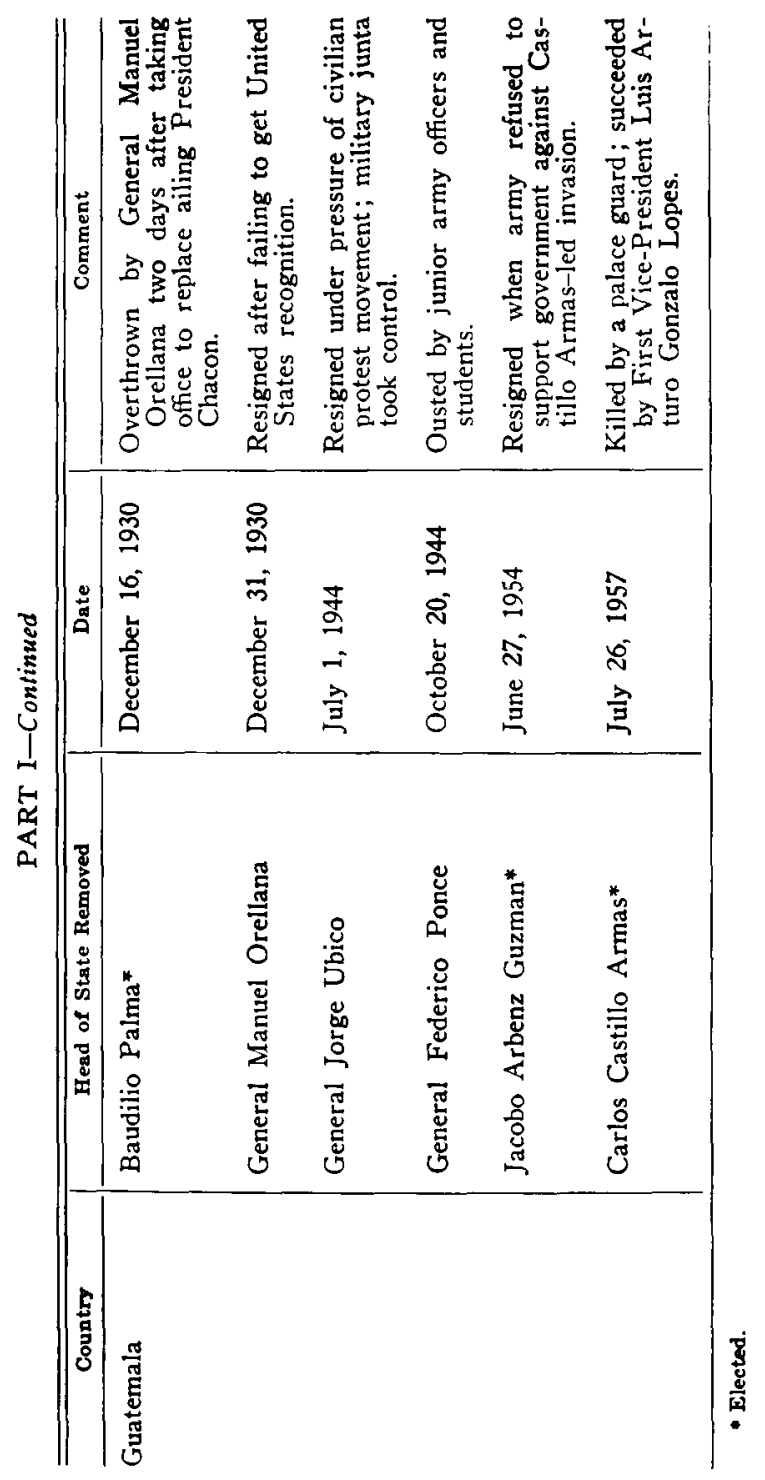




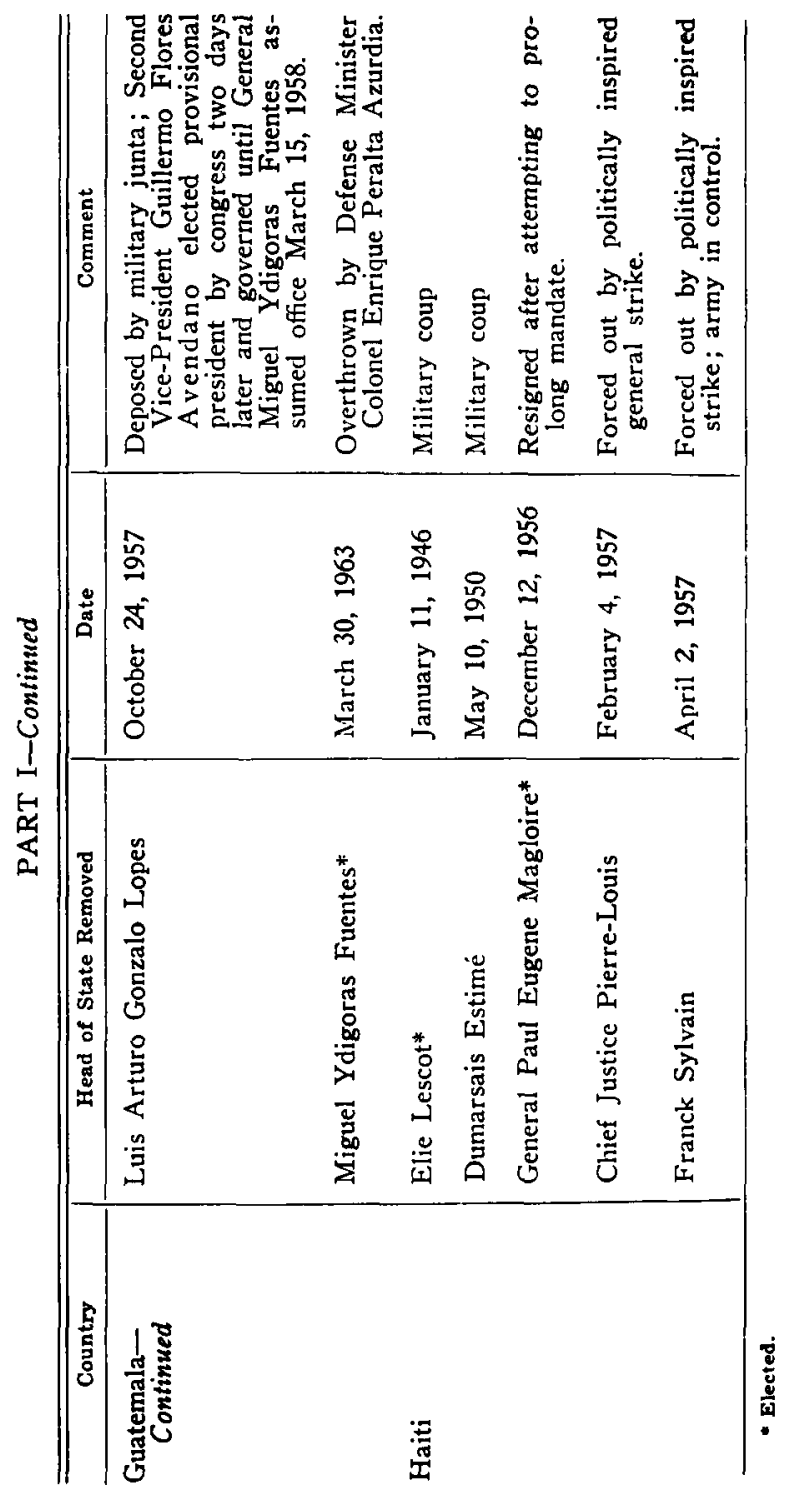




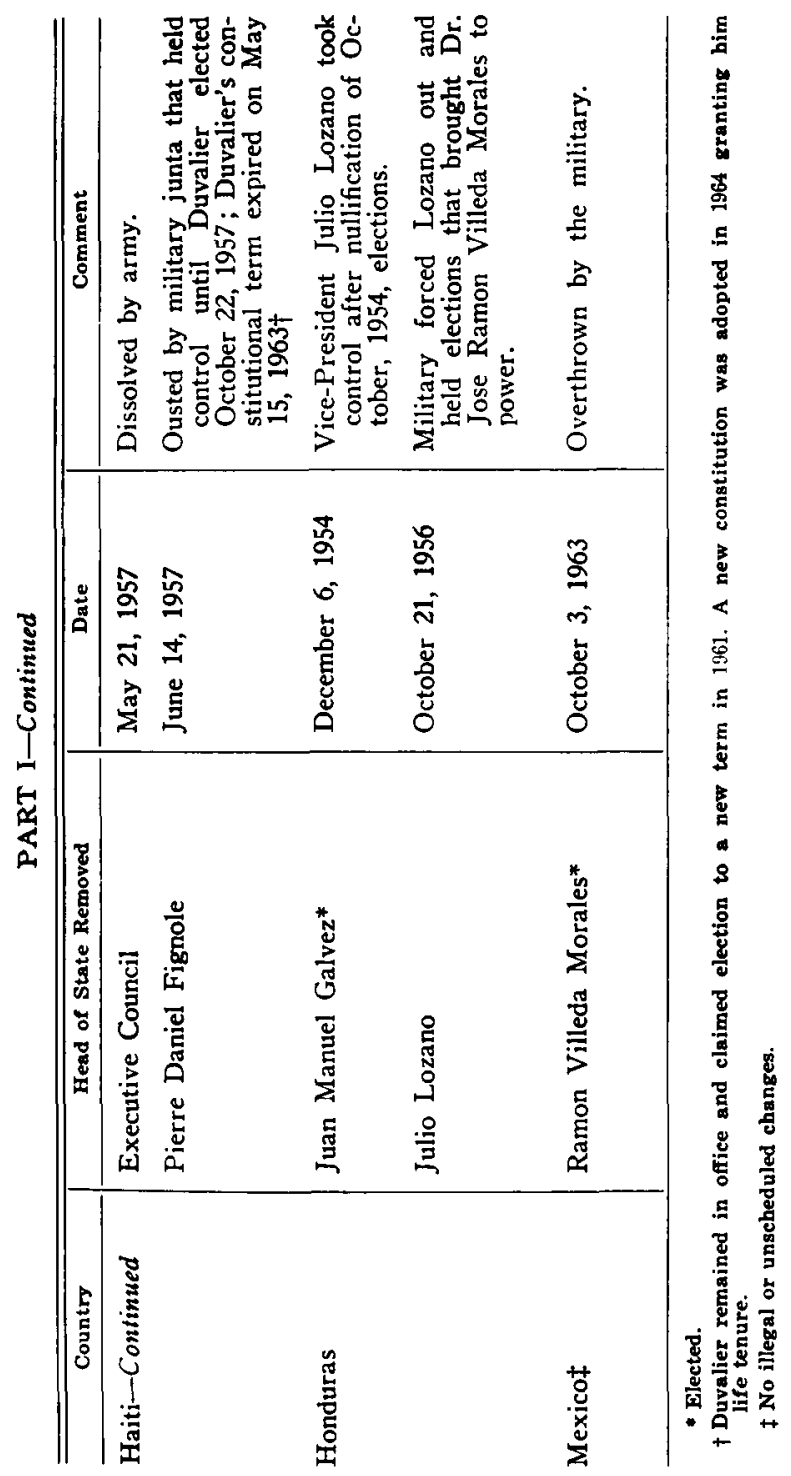




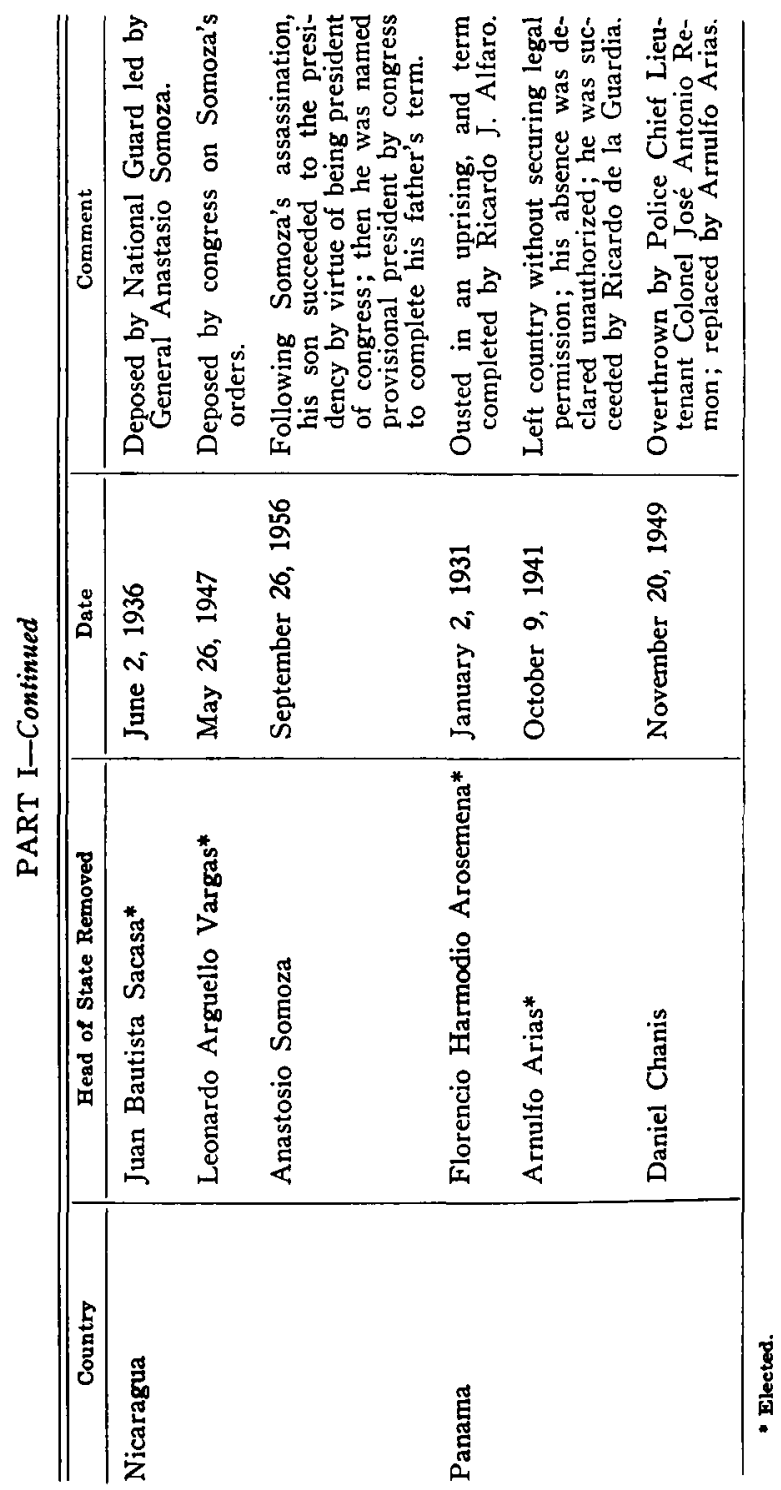




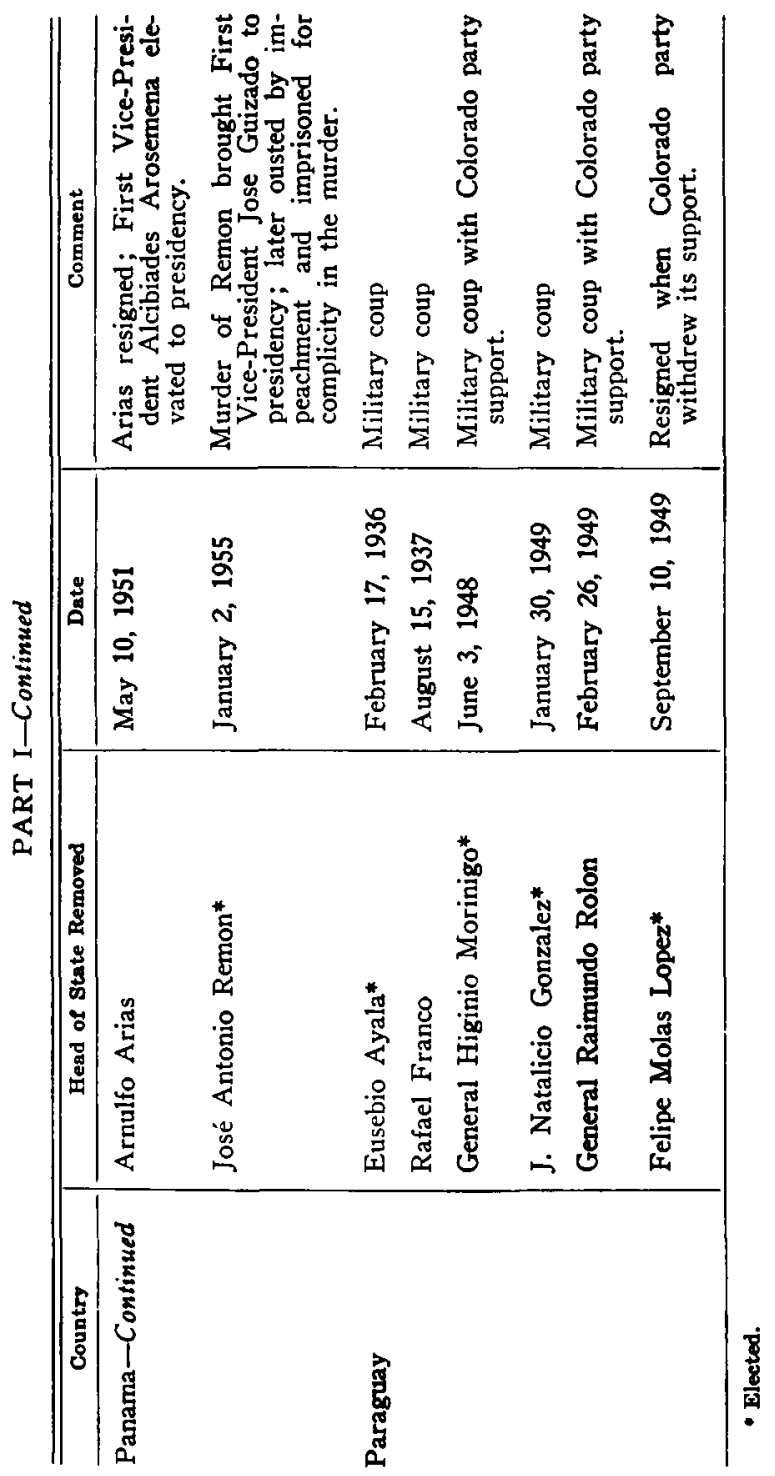




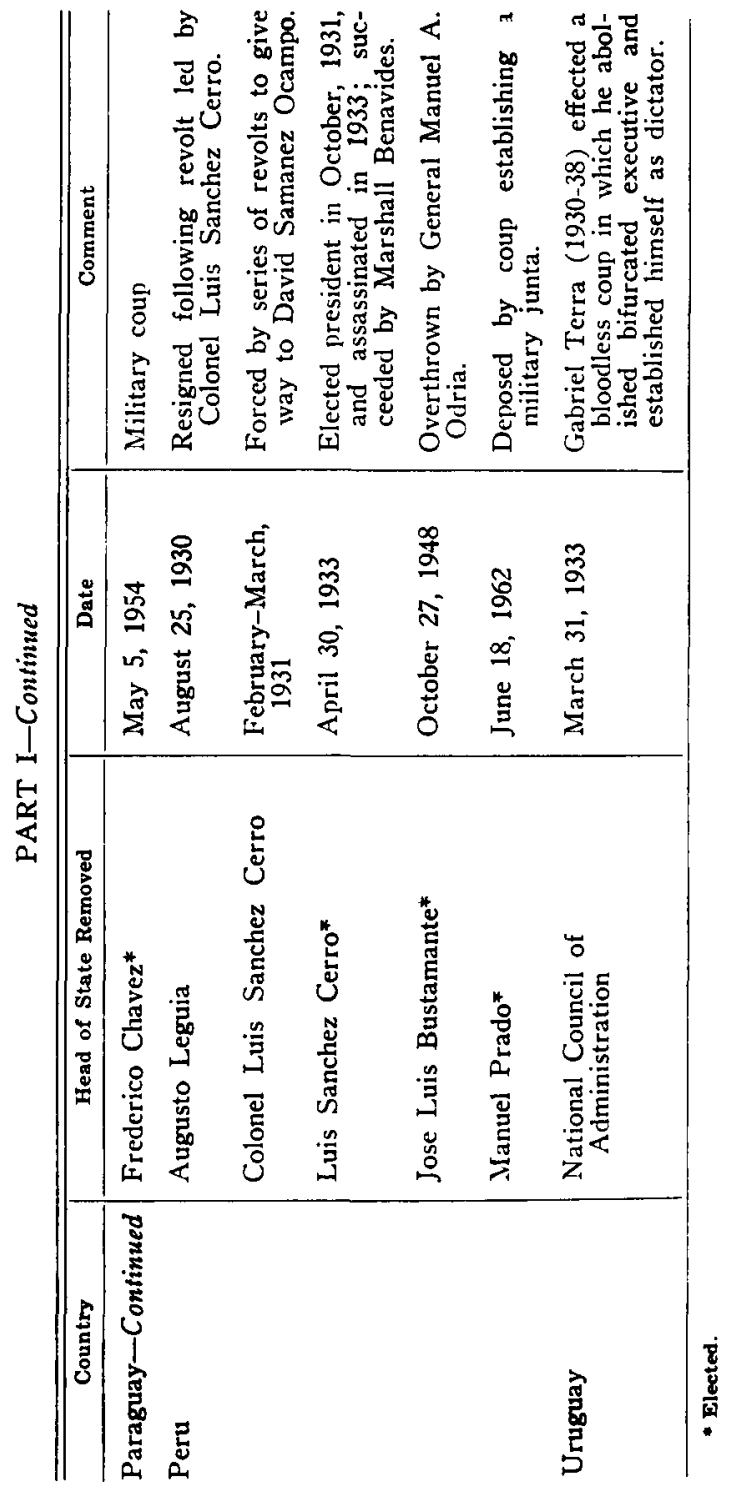




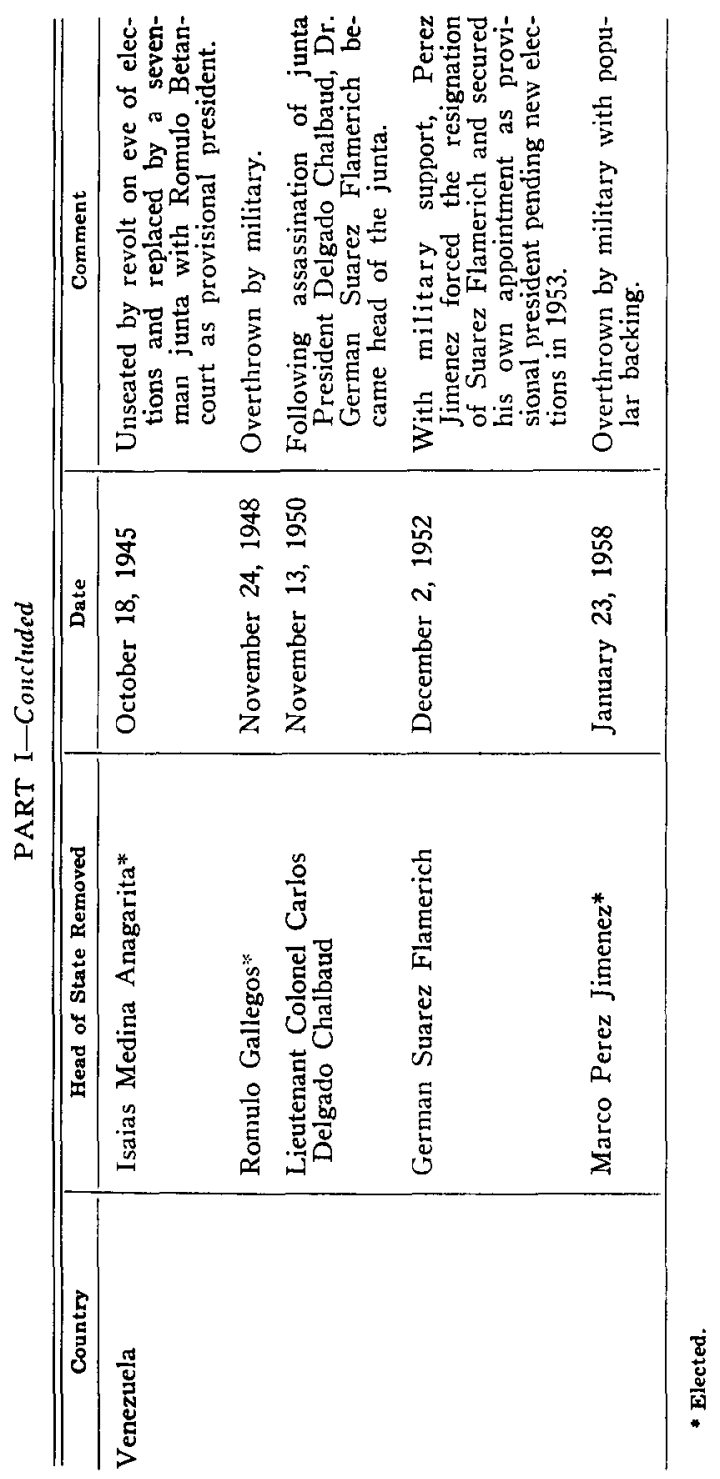




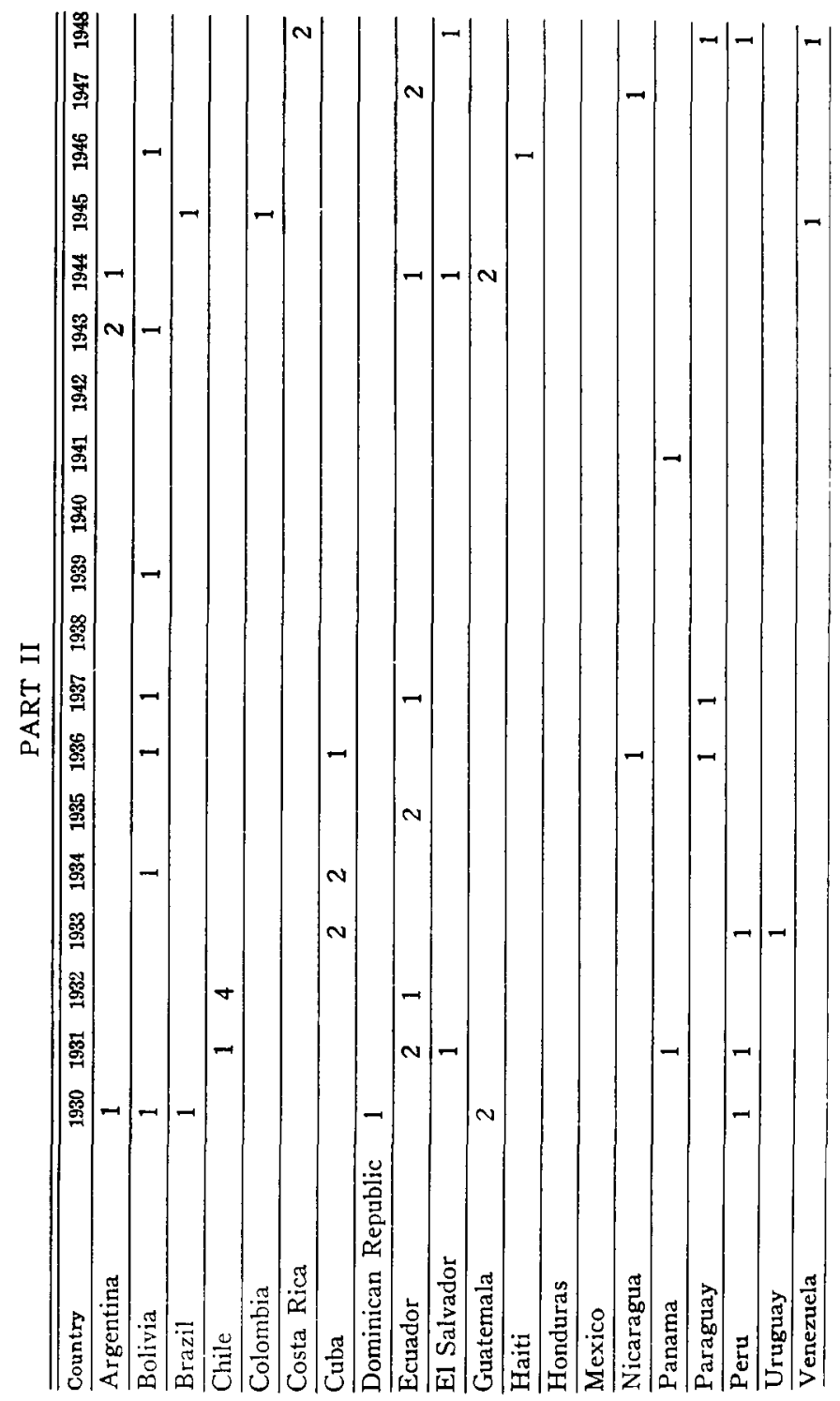




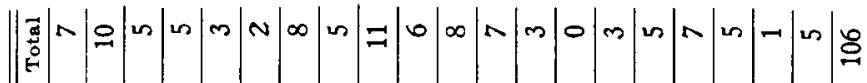

递

- -

政

害- -

焉

象

解

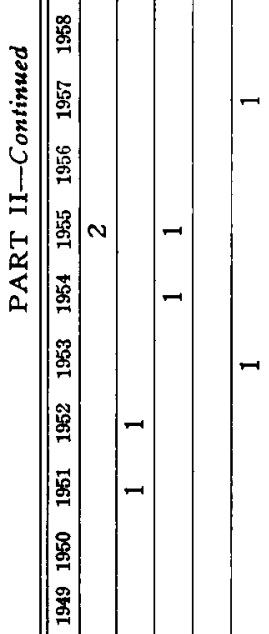

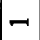

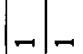

N

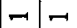

$-$

N

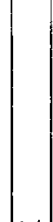

$-$

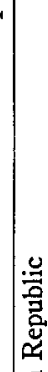

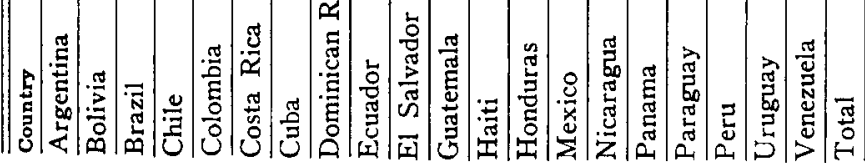




\section{Appendix B: U.S. National Objectives Regarding Overseas Internal Defense}

"Statement of U.S. Overseas Internal Defense Objectives" from the Deputy Assistant Secretary of State for Politico-Military Affairs (Mr. Jeffrey C. Kitchen) to the Deputy Assistant Secretary of Defense for International Security Affairs (Mr. William P. Bundy).

A basic premise of U.S. foreign policy is that the security of the U.S. and its fundamental values and institutions will best be preserved and enhanced as part of a community of free and independent nations. These nations should be characterized by economic growth, political responsibility and social justice in their domestic affairs and a due respect for established international behaviour in their foreign relations. In this regard, the U.S. is endeavoring to assist newly emerging and developing nations to maintain their freedom and independence and to deal effectively with their problems.

The U.S. believes that the processes of development and nation-building should be aided and encouraged but not manipulated by outside forces. The creation of a relatively stable international environment within which economic growth can occur and free people are able to determine their own form of government is therefore a primary U.S. objective. 
The achievement of this objective, however, is being challenged by an alien force which advocates and actively pursues the subjugation of free nations through subversion, insurgency and other means of indirect aggression.

The primary responsibility for preventing or combating internal aggression rests with the threatened country. It is the policy of the U.S. to assist threatened nations, when requested, to prevent or defeat communist inspired, suported or directed insurgency in order to ensure that all nations-especially those newly emerging and developing states-are given the opportunity to determine their own future. 


\section{Appendix C: Inter-American \\ Military Co-operation}

Resolution III of the Fourth Meeting of Consultation of the American Foreign Ministers, 1951. ${ }^{1}$

WHEREAS :

The military defense of the Continent is essential to the stability of its democratic institutions and to the well-being of its peoples:

The American Republics have assumed obligations under the Charter of the Organization of American States and the Inter-American Treaty of Reciprocal Assistance to assist any American States subjected to an armed attack, and to act together for the common defense and for the maintenance of the peace and security of the Continent;

The expansionist activities of international communism require the immediate adoption of measures to safeguard the peace and the security of the Continent;

The present grave international situation imposes on the American Republics the need to develop their military capabilities in order, in conformity with the Inter-American Treaty of Reciprocal Assistance: (1) to assure their individual and 
collective self-defense against attacks; (2) to contribute effectively to action by the Organization of American States against aggression directed against any of them; and (3) to make provision, as quickly as possible, for the collective defense of the Continent; and

The Ninth International Conference of American States, in its Resolution XXXIV, entrusted the preparation for collective self-defense against aggression to the Inter-American Defense Board, which, as the only inter-American technical-military organ functioning, is the suitable organ for the preparation of military plans for collective self-defense against aggression,

The Fourth Meeting of Consultation of Ministers of Foreign Affairs

RESOLVES :

1. To recommend to the American Republics that they orient their military preparation in such a way that, through self-help and mutual aid, and in accordance with their capabilities and with their constitutional precepts, and in conformity with the Inter-American Treaty of Reciprocal Assistance, they can, without prejudice to their individual self-defense and their international security: (a) increase those of their resources and strengthen those of their armed forces best adapted to the collective defense, and maintain those armed forces in such status that they can be promptly available for the defense of the Continent; and (b) cooperate with each other, in military matters, in order to develop the collective strength of the Continent necessary to combat aggression against any of them.

2. To charge the Inter-American Defense Board with preparing, as vigorously as possible, and keeping up to date, in close liaison with the Governments through their respective Delegations, the military planning of the common defense.

3. That the plans formulated by the Inter-American Defense Board shall be submitted to the Governments for their consideration and decision. To the end of facilitating such consideration and decision, the Delegations of the American 
Republics to the Inter-American Defense Board shall be in continuous consultation with their governments on the projects, plans, and recommendations of the Board.

4. To recommend to the Governments of the American Republics: (a) that they maintain adequate and continuous representation of their armed forces on the Council of Delegates, on the Staff of the Inter-American Defense Board, and on any other organ of the Board that may be established in the future; (b) that they actively support the work of the Board, and consider promptly all the projects, plans, recommendations of that agency; and (c) that they cooperate in the organization, within the Board, of a coordinated system of exchange of appropriate information.

1. Source: Fourth Meeting of Consultation of Ministers of Foreign Affairs of American States, March 26-April 7, 1951, Report of the Secretary of State (Washington, D.C.: Department of State publica. tion 4928, released May, 1953). 


\section{Appendix D: Contribution of the Armed Forces to the Economic-Social Development of the Countries}

Resolution XLVII of the Inter-American Defense Board, December 1, 1960

WHEREAS :

1. One of the weaknesses of the American Bloc is the lack of economic development to meet the need for required basic supplies for the rapid growth of the population;

2. One of the means of coping with the problem of the rapid growth of population is opening new ways of communications and incorporating into the economy of each country new agricultural lands, especially in underdeveloped regions;

3. In general, the expansion of the highway communications systems contributes effectively to facilitating the execution of the General Military Plan, with respect to the dispersion of industrial installations and to the development of strategic routes, to achieve the self-sufficiency of the Continent;

4. The General Military Plan for the Defense of the American Continent recognizes the desirability of doing everything possible to raise the standards of living of the peoples. with the object of effectively combatting Communist propaganda, which tries to exploit the ignorance and poverty of the underdeveloped areas: 
5. The Estimate of the Situation recognizes that "Often the military establishment of each country can plan a very useful role in economic development";

The Council of Delegates RECOMMENDS :

A. That the Governments of the American States take into consideration the advisability of employing organs of their Armed Forces, preferably in regions considered to be undercleveloped, in order to:

1. Undertake highway and settlement work, and promote the establishment of technical services;

2. Broaden the economic bases directed toward raising the standards of living of the peoples; and

3. Educate the native populations in their own surroundings and create reserves of specialized labor for specific types of work.

B. The use of military personnel for this purpose, to the extent and degree that the specific conditions in each country may determine, should not compete with private civilian activity nor decrease the capability of their Armed Forces for the accomplishment of their specific military tasks required by the General Military Plan.

C. The effort required by the organization, employment and maintenance of the services necessary for the accomplishment of this task could be covered in any bilateral agreements or arrangements mutually acceptable to any of the countries involved.

(signed) L. MATHEWSON

Lt. General, U.S. Army

Chairman

Official :

(Signed)

Willis M. SMyser

Colonel, U.S. Air Force

Secretary 


\section{Appendix E: Special Consultative Committee on Security against the Subversive Action of International Communism}

Resolution II of the Eighth Meeting of Consultation of the American Ministers of Foreign Affairs, 1962

\section{WHEREAS :}

International communism makes use of highly complex techniques of subversion in opposing, and in the task of counteracting such techniques which certain states may benefit from mutual advice and support;

The American states are firmly united for the common goal or fighting the subversive action of international communism and for the preservation of democracy in the Americas, as expressed in Resolution XXXII of the Ninth International Conference of American States, held in Bogota, in 1948, and that for such purpose they can and should assist each other, mainly through the use of the institutional resources of the Organization of American States; and

It is advisal)le, therefore, to make available to the Council of the Organization of American States a body of an advisory nature, made up of experts, the main purpose of which would he to advise the member governments which, as the case may be, require and request such assistance, 
The Eighth Meeting of Consultation of Ministers of Foreign Affairs, Serving as Organ of Consultation in Application of the Inter-American Treaty of Reciprocal Assistance,

RESOLVES :

1. To request the Council of the Organization of American States to maintain all necessary vigilance, for the purpose of warning against any acts of aggression, subversion, or other dangers to peace and security, or the preparation of such acts, resulting from the continued intervention of Sino-Soviet powers in this hemisphere, and to make recommendations to the governments of the member states with regard thereto.

2. To direct the Council of the Organization to establish a Special Consultative Committee on Security, composed of experts on security matters, for the purpose of advising the member states that they may desire and request such assistance, the following procedures being observed:

3. To urge the member states to take those steps that they may consider appropriate for their individual or collective self-defense, and to cooperate, as may be necessary or desirable, to strengthen their capacity to counteract threats or acts of aggression, subversion, or other dangers to peace and security resulting from the continued intervention in this hemisphere of Sino-Soviet powers, in accordance with the obligations established in treaties and agreements such as the Charter of the Organization of American States and the Inter-American Treaty of Reciprocal Assistance. 


\section{Appendix F: Précis of the Counterinsurgency Course (1963), the Special Warfare School Fort Bragg, North Carolina ${ }^{1}$}

U.S. Army Special Warfare School, Fort Bragg, N.C. (8 weeks) Counterinsurgency Operations Course $(33-G-F \sigma)$

Prerequisite-Counterinsurgency and Special Warfare Staff Officer Course (33-G-F7).

A. Purpose : To provide commissioned officers, both United States and Allied, and selected United States civilian government representatives, with a working knowledge in the nature and conduct of operations against Communist insurgents and the participation of United States military personnel in the civic action programs.

B. Concept of the Course: Using the Counterinsurgency and Special Warfare Staff Officer Course as a base, this specialized course directs major emphasis toward the causative factors underlying insurgency and includes the development of doctrine, tactics, and techniques applicable of military operations as part of civic action aimed at preventing and coping with such movements. Special attention is placed on the unity of effort required at the U.S. national level which terminates with the country team in the host country. The 
course emphasizes self-help techniques on the part of host countries and does not envision the large-scale employment of U.S. forces in direct support of foreign national programs.

C. Summary of the Program of Instruction: In consonance with the purposes and concept of the course, instruction includes:

1. The nature and causes of irregular movements.

2. The strategy and tactics of international communism in gaining control of and exploiting irregular movements.

3. The free world's concept and rationale of evolutionary change based on freedom, individual rights, the dignity of man, and social responsibilities.

4. The programs of free governments for meeting legitimate popular needs and aspirations to eliminate the causes of rebellion.

5. The contributions which armed forces can make to the nation-building programs in support of civil governments.

6. The tactics of armed forces in combatting guerrilla forces attempting to overthrow duly constituted governments.

7. The course concludes with a practical field exercise employing the techniques and skills taught in the classroom. The exercise includes the students of the other two specialized courses playing their normal role.

1. Source: Précis of Courses, Special Warfare School, $196 \dot{3}$. 


\section{Appendix G: Texts of a Military Assistance Agreement, a Military Mission Agreement, and Exchanges of Notes on Internal Security}

[When the Agreement takes the form of an exchange of notes, only the English language note is reproduced. The other note is a reply confirming the statements contained in the United States note.]

Military Assistance Agreements with Ecuador ANd PERU ${ }^{1}$

The Departments of State and Defense have announced the signing of bilateral military assistance agreements with the Governments of Ecuador and Peru.

The agreement with Ecuador was signed at Quito on February 20 on behalf of the United States by Paul C. Daniels, Ambassador to Ecuador, and on behalf of Ecuador by Neftali Ponce, Foreign Minister of Ecuador.

The agreement with Peru was signed at Lima on February 22 on behalf of the United States by Harold H. Tittmann, Jr., Ambassador to Peru, and on behalf of Peru by Manuel C. Gallagher, Foreign Minister of Peru. 
The Military Assistance Agreements just signed are consistent with, and conform to, inter-American instruments already in effect, such as the Inter-American Treaty of Reciprocal Assistance (the Rio Treaty), the resolution on InterAmerican Military Cooperation approved at the Washington Meeting of Foreign Ministers of 1951, and the continuous planning of the Inter-American Defense Board.

Negotiations for similar agreements, involving the provision of military-grant aid by the United States to promote the defense of the Western Hemisphere, are in progress with certain other American Republics. These negotiations were initiated under the program of military-grant aid for Latin America, authorized in the Mutual Security Act of 1951. The program to be carried out will assist in the development of the capabilities of the countries concerned to join in performing missions important to the security of all the American Republics. Such agreements illustrate the spirit of cooperation prevailing among the American Republics which makes it possible for them to concentrate, through self-help and mutual aid, upon increasing their ability to contribute to the collective defense of the Western Hemisphere, and, by serving as a deterrent to potential aggressors, contribute to the maintenance of world peace.

\section{TEXT OF AGREEMENT WITH ECUADOR ${ }^{2}$}

The Governments of the United States of America and of the Republic of Ecuador:

Conscious of their pledges under the Inter-American Treaty of Reciprocal Assistance and other international instruments to assist any American State subjected to an armed attack and to act together for the common defense and for the maintenance of the peace and security of the Western Hemisphere.

Desiring to foster international peace and security within the framework of the Charter of the United Nations through measures which will further the ability of nations dedicated to the purposes and principles of the Charter to participate effec- 
tively in arrangements for individual and collective self-defense in support of those purposes and principles;

Reaffirming their determination to give their full cooperation to the efforts to provide the United Nations with armed forces as contemplated by the Charter and to obtain agreement on universal regulations and reduction of armaments under adequate guarantee against violation:

Taking into consideration the support that the Government of the United States of America has brought to these principles by enacting the Mutual Defense Assistance Act of 1949, as amended, and the Mutual Security Act of 1951, which provide for the furnishing of military assistance to nations which have joined with it in collective security arrangements ;

Desiring to set forth the conditions which will govern the furnishing of such assistance by one contracting Government to the other;

Have agreed as follows :

\section{ARTICLE I}

1. Each Government will make or continue to make available to the other and to such additional governments as the parties hereto may in each case agree upon, such equipment, materials, services, or other military assistance as the Government furnishing such assistance may authorize and in accordance with such terms and conditions as may be agreed. The furnishing of any such assistance as may be authorized by either party hereto shall be consistent with the Charter of the United Nations. Such assistance shall be so designed as to promote the defense and maintain the peace of the Western Hemisphere and be in accordance with defense plans under which both Governments will participate in missions important to the defense and the maintenance of the peace of the Western Hemisphere. Assistance made available by the Government of the United States of America pursuant to this Agreement will be furnished under the provisions, and subject to all the terms, conditions and termination provisions of 
the Mutual Defense Assistance Act of 1949, the Mutual Security Act of 1951, acts amendatory and supplementary thereto and appropriation acts thereunder. The two Governments will, from time to time, negotiate detailed arrangements necessary to carry out the provisions of this paragraph.

2. The Government of Ecuador undertakes to make effective use of assistance received from the Government of the United States of America pursuant to this Agreement for the purpose of implementing defense plans, accepted by the two Governments, under which the two governments will participate in missions important to the defense and the maintenance of the peace of the Western Hemisphere, and will not, without the prior agreement of the Government of the United States of America, devote such assistance to purposes other than those for which it was furnished.

3. Arrangements will be entered into under which equipment and materials furnished pursuant to this Agreement and no longer required for the purposes for which it was originally made available (except equipment and materials furnished under terms requiring reimbursement) will be returned to the Government which furnished such assistance for appropriate disposition.

4. In the common security interest of both Governments, the Government of Ecuador undertakes not to transfer to any person not an officer or agent of such Government, or to any other Government, title to or possession of any equipment, materials, or services furnished to it by the Government of the United States of America under this agreement, without the prior agreement of the Government of the United States of America.

5. The two Governments will establish procedures whereby the Government of Ecuador will so deposit, segregate, or assure title to all funds allocated to or derived from any program of assistance under-taken by the Government of the United States of America so that such funds shall not be subject to garnishment, attachment, seizure or other legal process by any person, firm, agency, corporation, organization 
or government, when in the opinion of the Government of the United States of America any such legal process would interfere with the attainment of the objectives of the said program of assistance.

6. Each Government will take such security measures as may be agreed in each case between the two Governments in order to prevent the disclosure or compromise of classified military articles, services or information furnished by the other Government pursuant to this Agreement.

\section{ARTICLE II}

Each Government will take appropriate neasures consistent with security to keep the public informed of operations under this Agreement.

\section{ARTICLE III}

The two Governments will, upon request of either of them, negotiate appropriate arrangements between them to provide for the availability of patent licenses and technical information required in furtherance of the objectives of this Agreement. In these negotiations consideration shall be given to the inclusion of an undertaking whereby each Government will assume the responsibility for all claims of its nationals arising under such arrangements, and such claims arising in its jurisdiction of nationals of any country not a party to this Agreement.

\section{ARTICLE IV}

1. The Government of Ecuador undertakes to make available to the Government of the United States of America local currency in sucres in an amount to be agreed for the use of the latter Government for its administrative and operating expenditures in connection with carrying out the purposes of the Mutual Security Act.

The two Governments will forthwith initiate discussions with a view to determining the amount of such local currency in sucres and to agreeing upon arrangements for the furnishing of such local currency. 
2. The Government of Ecuador will, except as otherwise agreed, grant duty-free treatment and exemption from internal taxation upon importation or exportation to products, property, materials, or equipment imported into its territory in connection with this Agreement or any similar agreement between the United States of America and any other country receiving military assistance.

\section{ARTICLE V}

1. The Government of Ecuador agrees to receive personnel of the Government of the United States of America who will discharge responsibilities of the latter Government in connection with the implementation of this Agreement. Such personnel will be accorded facilities to observe the progress of assistance furnished pursuant to this Agreement. Such personnel who are nationals of the United States of America, including personnel temporarily assigned, will, in their relations with the Government of Ecuador, operate as a part of the Embassy of the United States under the direction and control of the Chief of the Diplomatic Mission, and shall be accorded all privileges and immunities conferred by international custom to Embassy personnel of corresponding rank. Privileges and courtesies incident to diplomatic status, such as diplomatic automobile license plates, inclusion on the "diplomatic list," and social courtesies may be waived by the Government of the United States of America for its personnel other than the senior military member and the senior Army, Navy and Air Force officer and their respective immediate deputies.

2. The two Governments will negotiate arrangements for classification of personnel and for appropriate notification thereof to the Government of Ecuador.

3. The Government of Ecuador shall grant, upon request of the Chief of the Diplomatic Mission of the United States of America, exemption from customs duties on articles imported for the personal use of such personnel and of members of their families. 
ARTICLE VI

Existing arrangements relating to Armed Forces missions of the United States of America established under other instruments are not affected by this Agreement and will remain in full force.

\section{ARTICLE VII}

In conformity with the principle of mutual aid, under which the two Governments have agreed as provided in Article I, to furnish assistance to each other, the Government of Ecuador agrees to facilitate the production and transfer to the Government of the United States of America for such period of time, in such quantities and upon such terms and conditions as may be agreed upon of raw and semi-processed strategic materials required by the United States of America as a result of deficiencies or potential deficiencies in its own resources, and which may be available in Ecuador. Arrangements for such transfers shall give due regard to reasonable requirements for domestic use and commercial export of Ecuador.

\section{ARTICLE VIII}

In the interest of their mutual security, the Government of Ecuador will cooperate with the Government of the United States of America in measures designed to control trade with nations which threaten the security of the Western Hemisphere.

\section{ARTICLE IX}

The Government of Ecuador, reaffirming its determination to join in promoting international understanding and good will and maintaining world peace, and to take such action as may be mutually agreed upon to eliminate causes of international tension, agrees to fulfill the military obligations which it has assumed under multilateral or bilateral agreements or treaties to which the United States is a party: to make, consistent with its political and economic stability, the full contribution per- 
mitted by its manpower, resources, facilities and general economic conditions to the development and maintenance of its own defensive strength and the defensive strength of the free world; and to take all reasonable measures which may be needed to develop its defense capacities.

\section{ARTICLE $\mathrm{X}$}

Whereas this Agreement has been negotiated and concluded on the basis that the Government of the United States of America will extend to the other party thereto the benefits of any provision in a similar agreement concluded by the Government of the United States of America with any other American Republic, it is understood that the Government of the United States of America will interpose no objection to amending this Agreement in order that its provisions may conform, in whole or in part, to the corresponding provisions of any similar Military Assistance Agreement, or agreements amendatory thereto, concluded with an American Republic.

\section{ARTICLE XI}

1. This Agreement shall enter into force on the date of signature, and shall continue in force until one year after the receipt by either party of written notice of the intention of the other party to terminate it, except that the provisions of Article I, paragraphs 2 and 4 and agreements made pursuant to the provisions of Article I, paragraphs 3,5, and 6 and of Article III shall remain in force unless otherwise agreed by the two Governments.

2. The two Governments shall, upon the request of either of then, consult regarding any matter relating to the application or amendment of this Agreement.

3. This Agreement shall be registered with the Secretary General of the United Nations.

Done in duplicate, in the English and Spanish languages, both equally authentic, at Quito, this twentieth day of Fehruary, 1952 . 


\section{Joint Brazil-United States Military and DefENSE CoMmission}

"Department of State Treaties and Other International Acts Series," No. 3421

Agreement effected by exchange of notes

Signed at Rio de Janeiro August 1 and September 20, 1955 ; Entered into force September 20, 1955.

The American Ambassador to the Brazilian Minister of Foreign Affairs

THE FOREIGN SERVICE

OF THE

UNITED STATES OF AMERICA

EMBASSY OF THE

UNITED STATES OF AMERICA

RIO DE JANEIRO, AUGUST 1, 1955.

\section{EXCELLENCY :}

I have the honor to advise Your Excellency that the Government of the United States of America, recognizing the long friendship and mutual cooperation which have existed between our two Governments throughout their history and mindful of the ever-increasing community of interests which our two Governments share, and desiring to further the ability of the United States of America and of the Republic of the 
United States of Brazil to participate more effectively in arrangements for their individual and mutual security and the security of the hemisphere within the scope of the InterAmerican Treaty of Reciprocal Assistance and the framework of the Charter of the United Nations, proposes the following agreement :

(1) The joint Brazil-United States Military Commission (JBUSMC), originally established in Rio de Janeiro during World War II by the two Governments as a means of assisting each other in achieving their common goal of mutual security, will continue to function as the principal agency in the United States of Brazil for facilitating military cooperation between the two countries.

(2) The Joint Brazil-United States Defense Commission (JBUSDC), originally established in Washington, D.C., during World War II by the two Governments as a means of assisting each other in achieving their common goal of mutual security, will continue to function as the principal agency in the United States of America for facilitating military cooperation between the two countries.

(3) Each Government, upon being appropriately advised, agrees to receive personnel of the other Government who will discharge responsibilities of that Government in connection with the implementation of this agreement.

(4) Arrangements governing the composition, functions, and procedures of the two commissions may be entered into from time to time, as necessary, by the appropriate military authorities of the two Governments.

(5) This Agreement shall remain in effect until one year from the date of notice by either Government of its intention to terminate the Agreement.

If the foregoing provisions are acceptable to Your Excellency's Government, I have the honor to propose that this note and Your Excellency's reply thereto shall be regarded as constituting an agreement between the two Governments concerning this matter. 
Accept, Excellency, the renewed assurances of my highest esteem and consideration.

\section{James Clement Dunn}

His Excellency

Raul Fernandes,

Minister of Foreign Affairs of Brazil,

Rio de Janeiro

Exchange of Notes with Guatemala on Furnishing Articles and Services to Strengthen InternalSecurity Caipabilities

"Department of State Treaties and Other International Acts Series," No. 5173

Agreement effected by exchange of notes

Signed at Guatemala May 25 and August 2, 1962;

Entered into force August 2, 1962.

The American Ambassador to the Guatemalan Minister of Foreign Relations

EXCELLENCY :

EMBASSY OF THE

UNITED STATES OF AMERICA

guatemala, May 25, 1962.

I have the honor to refer to recent conversations between the representatives of our two Governments concerning the furnishing of military assistance to the Government of Guate- 
mala for the purpose of contributing to its internal security capabilities. I am pleased to inform Your Excellency that the Government of the United States of America is prepared to furnish such assistance for this purpose as may be mutually agreed by representatives of our two governments, subject to the following understandings:

1. Defense articles and defense services shall be or continue to be furnished for internal security purposes in accordance with the terms and conditions of the Military Assistance Agreement between the United States of America and the Republic of Guatemala, signed June $18,1955,{ }^{3}$ at Guatemala City. In view of the special purpose of assistance furnished hereunder, however, the requirement of the third sentence of Article I, paragraph 1, of that Military Assistance Agreement, and so much of the requirements of the first sentence of Article 1, paragraph 2, thereof as relates to implementation of defense plans under which our two governments participate in missions important to the defense and maintenance of the peace of the Western Hemisphere shall not be applicable to such assistance.

2. Defense articles and defense services furnished hereunder may be used for the purpose of implementing the defense plans referred to in paragraph number 1 of this note when not required for the purpose of maintaining internal security and, at such time as so used, shall be subject to all the requirements of the Military Assistance Agreement referred to in paragraph number 1 of this note.

3. Defense articles and defense services furnished hereunder shall be subject to the Agreement effected by an exchange of notes signed at Guatemala City on December 16, 1957,4 which relates to disposition of military equipment and materials no longer required for the purposes stated in paragraphs number 1 and 2 of this note.

I have the honor to propose that, if these understandings are acceptable to your Government, this note and Your Excellency's reply concurring therein shall constitute an agreement between our two Governments which shall enter into force on the date of your reply. 
Accept, Excellency, the renewed assurances of my highest consideration.

$$
\text { JohN O. BeLL }
$$

His Excellency

$$
\begin{gathered}
\text { JESUS UNDA MURILLo } \\
\text { Minister of Foreign Relations } \\
\text { Republic of Guatemala }
\end{gathered}
$$

\section{Exchange of Notes with Paraguay Regarding Road Construction}

"Department of State Treaty and Other International Acts Series," No. 5532

Capability of the Paraguayan Army

Agreement effected by exchange of notes Signed at Asuncion February 10, 1964; Entered into force February 10, 1964.

The American Ambassador to the Paraguayan Minister of Foreign Affairs

$$
\text { ASUncion, February 10, } 1964 .
$$

\section{EXCELLENCY :}

I have the honor to refer to recent conversations between representatives of our two Governments concerning the furnishing of assistance by the Government of the United States 
of America to the Government of Paraguay for the purpose of promoting the defense of Paraguay by increasing the road construction and maintenance capability of the Paraguayan Army and to propose the following understanding with respect to this assistance:

1. Road construction and maintenance equipment, and related materials and services, will be furnished for the abovementioned purpose subject to the terms and conditions of applicable United States laws and regulations, and to such other conditions as may be specified in arrangements between representatives of our two Governments. The equipment, materials and services to be provided under this agreement shall not be used for any purpose other than road construction and maintenance in Paraguay and shall not be transferred to, nor used by, anyone not an officer, employee or agent of the Government of Paraguay, without the prior consent of the United States Government. The Government of Paraguay will provide substantially the same degree of security protection as that afforded to such equipment, materials and services by the Government of the United States of America.

2. The Government of Paraguay will, as the United States may require, permit continuous observation and review by, and furnish necessary information to, representatives of the Government of the United States of America with regard to the use of such equipment, materials and services, and will offer for return to the United States such equipment and materials when no longer needed for the purpose of road construction and maintenance.

I have the honor to propose that, if these understandings are acceptable to the Govermment of Paraguay, the present note and your note in reply concurring therein shall constitute an agreement between our two Governments, which shall enter into force on the clate of your note.

Accept, Excellency, the renewed assurances of my highest consideration. 


\section{William P. SNow}

His Excellency

Dr. Raúl Sapena Pastor

Minister of Foreign Affairs

of the Republic of Paraguay

Ascunsion

Exchange of Notes with Argentina, Providing for Military Equipment

"Department of State Treaty and other International Acts Series," No. 5594

Agreement effected by exchange of notes

Signed at Buenos Aires May 10, 1964 ;

Entered into force May 10, 1964.

The American Ambassador to the Argentine Minister of Foreign Affairs and Worship

$$
\text { BUENOS AIRES, May 10, } 1964
$$

\section{EXCELLENCY :}

I have the honor to refer to the enclosed agreed texts in English and Spanish of a Memorandum of Understanding on the subject of cooperation between our two Governments in making available military equipment, materials and services. Both English and Spanish texts are equally authentic. 
Upon receipt of a note from Your Excellency indicating that the understandings confirmed in the enclosed agreed texts are acceptable to the Government of Argentina, the Government of the United States will consider that this note and your reply thereto constitute an agreement on this subject between the two governments, the agreement to enter into force on the date of your note in reply.

Accept, Excellency, the assurances of my highest consideration.

\section{Robert McClintock}

Enclosure: Memorandum of Understanding

His Excellency

Mrguel Angel Zavaia Ortiz,

Minister of Foreign Affairs and Worship, Buenos Aires.

\section{MEMORANDUM OF UNDERSTANDING}

The Government of the United States of America and the Government of the Republic of Argentina:

Desiring to foster international peace and security within the framework of the Charter of the United Nations, ${ }^{5}$ through measures which will further the ability of nations dedicated to the purposes and principles of the Charter to participate effectively in arrangements for self-defense in support of those principles and purposes;

Conscious of their pledges under the Inter-American Treaty of Reciprocal Assistance ${ }^{6}$ and other international instruments to assist any American State subjected to an armed attack and to act together for the common defense and for the maintenance of the peace and security of the American continent;

Taking account of the objectives set forth in Resolution I and II adopted at Punta del Este on January 31, 1962, at the 
Eighth Meeting of Consultation of Ministers of Foreign Affairs, Serving as Organ of Consultation in Application of the Inter-American Treaty of Reciprocal Assistance;

Desiring to set forth the conditions which will govern the furnishing of such assistance by one Government Party to the other ;

Have mutually agreed on the following understanding:

\section{ARTICLE I}

1. Each of the parties to this agreement is willing to take all reasonable measures, consistent with economic and political stability, to develop its own defense capacity, and is willing to participate in a cooperative program to the same ends.

2. Each Government will make or continue to make available to the other such defense articles and defense services, or other military assistance, as the one Government may request and the other Government may authorize in accordance with such terms and conditions as may be agreed.

3. The furnishing of any such assistance as may be authirized by either Government party hereto shall be consistent with the Charter of the United Nations and the Inter-American Treaty of Reciprocal Assistance.

4. The assistance to be furnished by the parties under this agreement shall be subject to the respective constitutional provisions and to the terms and conditions of the applicable laws which are in force in each country at the time of furnishing such assistance, and those terms and conditions shall be made known. Any future amendments or additions to such terms and conditions shall not apply to assistance already furnished. Future terms and conditions under legislation will be made applicable through arrangements pursuant to paragraph 5 of this article.

5. In conformity with their respective constitutional procedures, the two Governments through appropriate representatives shall, from time to time, enter into detailed arrangements to carry out the provisions of this agreement. Pursuant to such 
arrangements, military assistance may be furnished either for the purpose of requirements based upon the above-mentioned Resolutions I and II adopted at Punta del Este on January 31,1962 , or for the purpose of defense missions which are important to the maintenance of peace and security in the American Continent, in accordance with such plans as may be agreed to in this connection.

6. Neither Government will, without prior agreement of the other Government, devote such assistance furnished to it to purposes other than those for which it was furnished.

7 Arrangements will be entered into under which any defense articles furnished pursuant to this agreement, other than on a reimbursable basis, and no longer required for the purpose specified in the detailed arrangements provided for in paragraph 5 of this Article, will be offered for return and appropriate disposition to the Government which furnished such assistance.

8. Neither Government will permit any use of defense articles and defense services furnished by the other Government under this agreement by anyone not an officer, employee, or agent of such Government without the prior agreement of the Government which furnished the assistance.

9. Neither Government will transfer, nor permit any officer, employee, or agent of that Government to transfer, such defense articles and defense services by gift or otherwise without the prior agreement of the Government which furnished the assistance.

10. Each of the Governments will maintain the security of the defense articles and defense services transferred to it by the other Government under this agreement, and through arrangements under paragraph 5 of Article I will provide the highest degree of security protection that the receiving Government would provide to its own articles and services. Where the items or information to be furnished carry a security classification provided by the furnishing government, such arrangements shall specify the degree of security protection to be afforded such items or information. 


\section{ARTICLE II}

1. In connection with the receipt of military assistance under this agreement, each party will agree to accept, when appropriate, personnel of the other party for the purpose of coordinating the execution of said assistance. Such personnel shall be composed of citizens of the country furnishing it.

2. The two Governments shall agree on the ranks and number of the above-mentioned personnel, who will perform the responsibilities indicated in paragraph 1 of this Article. Such personnel shall be granted reasonable facilities and services, including office space, custodial services, and suitable motor transportation, necessary to enable them to perform their duties in connection with this agreement.

\section{ARTICLE III}

1. This agreement shall continue in force until six months after either Govermment receives from the other written notice of that Government's intention to terminate it. In any case, notwithstanding a declaration of intention to terminate this agreement, the provisions of paragraphs $6,7,8,9$ and 10 of Article I, shall continue in force until the two Governments agree to the contrary.

2. At the request of either Government, the two Governments will consult concerning any matter relating to an amendment or change considered desirable in this agreement as a result of its application.

1. Source: Department of Statc Bulletin, XXVI, No. 662 (March $3,1952), 336 \mathrm{ff}$.

2. For text of similar agrcement with Peru, see Department of State press release 139 of February 22, 1952.

3. TIAS $3283 ; 6$ UST 2107.

4. TIAS $3966 ; 8$ UST 2463.

5. TIAS $993 ; 59$ Stat. 1031.

6. TIAS $1838 ; 62$ Stat. (pt. 2), 1681. 


\section{Appendix H: "Problem Area": An Excerpt from "Military Civic Action" (1964), Prepared by the Department of the Army ${ }^{1}$}

\section{Military Civic Action}

As the result of approximately three years of experience, general problem areas have arisen, both in-country and in Washington in supporting the progran.

a. In-country problems.

\section{(1) Personal ambitions.}

Since civic action is designed to be a program which directly benefits the people, it logically has a decided impact on their affections and allegiances. Quite naturally, therefore. there will be a direct political dividend accruing to the persons who appear responsible for the program. The solution to this problem rests in having the Head of State sponsor the civic action program.

(2) Bureaucratic functional jealousies.

Since civic action is involved in many fields of social and economic development, it can be seen that it may extend into the functional fields of the Ministries of Health, Education, Economics, and Transportation, among others. To prevent conflicts of interest, a proper working relationship is 
established early in the program. This problem must first be recognized, and then if the Head of State personally sponsors the program, the various ministries will hesitate to obstruct it. Finally, the civic action program must complement and not compete with the various ministerial programs.

(3) Selection of projects is another problem area. This problem is one to which the Country Tean must address itself. Its solution rests solely with the Country Team.

(4) The "Pork Barrel."

This problem is not unique to the United States. In the developing nations, according priorities to civic action can become a real political issue. Probably the best solution lies in the development of a long-range program and undertaking projects which are of benefit to large segments of the population.

(5) Problems within indigenous armed forces include:

(a) Not all armed forces personnel will be interested in doing civic action.

(b) Armed forces units may not be located where civic action projects are most needed.

(c) Other operational requirements may prevent military units from doing civic action.

(d) The living conditions of the military personnel and their families may be as low or lower than those of their needy countrymen.

(e) The personnel of the armed forces may be of such a low caliber that they possess little or no technical capability to support a civic action program.

(6) The people themselves present certain problems. Since civic action is directed toward the people, the maximum henefit is obtained when the people can participate. For this reason, small, high impact, short term of completion projects should have high priority. Surveys must be conducted to con- 


\section{Appendix H}

sider the character, customs, taboos, and religious mores of ethnic and tribal groups which make up the population.

1). Problem areas affecting U.S. Army support of the program.

(1) Shortage of personnel trained in civic action techniques.

(2) Shortage of personnel with required language and area training.

(3) Highly trained, technically qualified functional specialists required to support the program are in short supply.

(4) Long lead times required to procure type of equipment needed to support the program, particularly the impact projects.

1. Pages 17-19. 


\section{Appendix I: Resolution Regarding the Dominican Republic Adopted by the Tenth Meeting of Consultation of the American Ministers of Foreign Affairs, 1965}

INTER-AMerican Force ${ }^{1}$

WHEREAS :

This Tenth Meeting of Consultation at its session on May 1, 1965, established a Special Committee composed of five of its members to go to the Dominican Republic to seek the reestablishment of peace and normal conditions in the territory of that republic;

The above mentioned resolution requests the governments of the member states and the Secretary General of the Organization of American States to extend their full cooperation to facilitate the work of the Special Committee;

The formation of an inter-American force will signify ipso facto the transformation of the forces presently in Dominican territory into another force that would not be of one state or of a group of states but that of the Organization of American States, an interstatal organization, which Organization is charged with the responsibility of interpreting the democratic will of its members; 
The American states being under the obligation to provide reciprocal assistance to each other, the Organization is under even greater obligation to safeguard the principles of the Charter and to do everything possible so that in situations such as that prevailing in the Dominican Republic appropriate measures may be taken leading to the re-establishment of peace and normal democratic conditions;

The Organization of American States being competent to assist the member states in the preservation of peace and the re-establishment of normal democratic conditions, undoubtedly it is also competent to provide the means that reality and circumstances require and that prudence counsels as adequate for the accomplishment of such purposes; and

The Special Committee that went to the Dominican Republic, in its second message to this Meeting of Consultation, advises the formation of an inter-American force to achieve the objectives determined by the Meeting.

THE TENTH MEETING OF CONSULTATION OF MINISTERS OF FOREIGN AFFAIRS

\section{RESOLVES :}

1. To request governments of member states that are willing and capable of doing so to make contingents of their land, naval, air or police forces available to the Organization of American States, within their capabilities and to the extent they can do so, to form an inter-American force that will operate under the authority of this Tenth Meeting of Consultation.

2. That this Force will have as its sole purpose, in a spirit of democratic impartiality, that of cooperating in the restoration of normal conditions in the Dominican Republic, in maintaining the security of its inhabitants and the inviolability of human rights, and in the establishment of an atmosphere of peace and conciliation that will permit the functioning of democratic institutions.

3. To request the commanders of the military contingents that make up this Force to work out directly among them- 
selves and with a committee of this Meeting the technical measures necessary to establish a Unified Command of the Organization of American States for the coordinated and effective action of the Inter-American Force. In the composition of this Force, an effort will be made to see that the national contingents shall be progressively equalized.

4. That at such time as the Unified Command of the Organization of American States shall have determined that the Inter-American Force is adequate for carrying out the purposes set forth in the resolution adopted by this Meeting on May 1, 1965, the full responsibility of fulfilling these purposes shall be assumed by that Force.

5. That the withdrawal of the Inter-American Force from the Dominican Republic shall be determined by this Meeting of Consultation.

6. To continue in session in order to keep the situation under review, to receive the report and recommendations of the Special Committee, and in the light thereof to take the necessary steps to facilitate the prompt restoration of democratic order in the Dominican Republic.

7. To inform the Security Council of the United Nations of the text of this resolution.

(Adopted at the third plenary session, held on May 6, 1965)

[2]

Unified Command of The Inter-American Force ${ }^{2}$

(ADditional FUNCTIONS For THE SPECtal COMMitTEE)

WHEREAS :

On May 1 the Tenth Meeting of Consultation established a Special Committee, composed of representatives of five mem- 
ber states, to go to the city of Santo Domingo to seek the reestablishment of peace and normal conditions; and

At the Session held on May 6, the Meeting adopted a resolution, requesting the member states to contribute contingents to form an Inter-American Force that would operate under the authority of this Meeting and providing that the necessary measures would be taken for the establishment of a Unified Command of the Organization of American States for the coordinated and effective action of that Force,

THE TENTH MEETING OF CONSULTATION OF MINISTERS OF FOREIGN AFFAIRS

\section{RESOLVES :}

1. To express the thanks of this Meeting to the Special Committee established by the resolution of May 1, 1965, for the outstanding work it has done to date.

2. To continue the existence of that Committee so that it may carry out the tasks that were assigned to it in that resolution.

3. To request that Committee to assume the functions assigned to the committee referred to in paragraph 3 of the operative part of the resolution adopted on May 6, 1965.

(Adopted at the sixth plenary session, held on May 10, 1965)

Appeal for a Cease-fire in the Dominican Republic ${ }^{3}$

THE TENTH MEETING OF CONSULTATION OF MINISTERS OF FOREIGN AFFAIRS 
RESOLVES :

To appeal once again to the parties in conflict for a cease-fire in order to create conditions favorable to peace and normality in the Dominican Republic.

(Adopted at the ninth plenary session, held on May 19, 1965)

[4]

Provisions Relating to the Inter-American Force ${ }^{4}$

THE TENTH MEETING OF CONSULTATION OF MINISTERS OF FOREIGN AFFAIRS

RESOLVES :

1. That the Secretary General of the Organization of American States shall assume the functions referred to in paragraph 3 of the resolution adopted by this Meeting of Consultation on May 6, 1965.

2. That this Meeting shall deternine the mission and objectives of the Inter-American Force in accordance with the sole purpose set forth in paragraph 2 of the abovementioned resolution of May 6.

3. To request the Government of Brazil to designate the Commander of the Inter-American Force and the Government of the United States to designate the Deputy Commander of that Force.

4. To appoint a committee composed of those members designated by the President of the Tenth Meeting of Consultation to study the functioning and maintenance of the 
Inter-American Force, and to present a report to the present Meeting of Consultation.

(Adopted at the thirteenth plenary session, held on May 22, 1965. At this same session, the President appointed as members of the committee the Delegations of Brazil, Costa Rica, El Salvador, Honduras, Nicaragua, and the United States of America, as well as those of other member states that contribute contingents to the Inter-American Force.)

Ad Hoc Committee for the Restoration of Democratic Order in the Dominican Republic

WHEREAS :

The situation prevailing in the Dominican Republic continues to be a danger to peace; and

The Organization of American States should continue to exert efforts and to take the steps necessary for the prompt restoration of democratic order in that republic so that the Dominican people may freely decide their own destiny,

THE TENTH MEETING OF CONSULTATION OF MINISTERS OF FOREIGN AFFAIRS

RESOLVES :

1. To reiterate its confidence in the Secretary General of the Organization of American States and its gratitude for the way he has been carrying out the mission that the Council of the Organization of American States and the Tenth Meeting of Consultation entrusted to him.

2. To appoint an ad hoc committee made up of representatives of Brazil, El Salvador, and the United States of America, 
which will act on behalf of the Tenth Meeting of Consultation for the following purposes:

a. To continue the task begun by the Special Committee and now being carried out by the Secretary General of providing good officers to all parties, for the purpose of achieving the establishment of a climate of peace and reconciliation that will permit the functioning of democratic institutions in the Dominican Republic and its economic and social recovery;

b. To provide the Inter-American Force, through its Commander and on behalf of the Tenth Meeting of Consultation under whose authority it functions, the directives necessary for the effective accomplishment of that Force's sole purpose as defined in paragraph 2 of the resolution adopted by this Meeting on May 6, 1965 ; and

c. To keep the Tenth Meeting of Consultation duly informed of its activities and the results thereof.

\section{(Adopted at the fourteenth plenary session, held on June 2, 1965)}

Inter-American Peace Force

THE TENTH MEETING OF CONSULTATION OF MINISTERS OF FOREIGN AFFAIRS

RESOLVES :

That the force created by resolution of this Meeting of Consultation on May 6, 1965, shall be called the Inter-American Peace Force.

(Adopted at the fourteenth plenary session, held on June 2, 1965) 


\section{Appendix I}

1. Registered as Doc. 39, Rev. 2 of the Meeting.

2. Registered as Doc. 54, Rev. 2 of the Meeting.

3. Registered as Doc. 82, Rev. 2 of the Meeting.

4. Registered as Doc. 93, Rev. 2 of the Meeting.

5. Registered as Doc. 118, Rev. 2 of the Meeting.

6. Ambassador Ilmar Penna Marinho (Brazil), Ambassador Ramon de Clairmont Duenas (El Salvador), and Ambassador Ellsworth Bunker (United States of America) were designated by their respective governments to serve on the ad hoc committee.

7. Registered as Doc. 118, Rev. 2 of the Meeting. 
A Selected Bibliography 



\section{A Selected Bibliography}

\section{Books}

Adams, Richard N. (ed.). Social Change in Latin America Today. New York: Vintage, 1960.

Alba, Victór. El militarismo. Mexico: Biblioteca de Ensayos Sociologicos, 1959.

Alexander, Robert J. Communism in Latin America. New Brunswick: Rutgers University Press, 1957.

- Latin American Politics and Government. New York: Harper, 1965.

Cross, James E. Confict in the Shadows: The Nature and Politics of Guerrilla War. New York: Doubleday, 1963.

Daniels, Walter M. (ed.). Latin America in the Cold War. New York: Wilson, 1952.

Diffie, Bailey. Latin American Civilization: Colonial Period. Harrisburg: Stackpole, 1947.

Deutsch, Karl W., and Foltz, William J. (eds.), Nation Building. New York: Atherton, 1962.

Eckstein, Harry (ed.). Internal War: Problems and Approaches. New York: Free Press, 1964.

Eisenhower, Milton B. The Wine Is Bitter: The United States and Latin America. New York: Doubleday, 1963. 
Finer, Samuel. The Man on Horseback. New York: Praeger, 1962.

Galula, David. Counterinsurgency Warfare: Theory and Practice. New York: Praeger, 1964.

Golay, Frank H. The Philippines: Public Policy and $\mathrm{Na}$ tional Economic Development. Ithaca, N.Y.: Cornell University Press, 1961.

Guevara, Ernesto "Che." On Guerrilla Warfare. New York: Praeger, 1961.

Heilbroner, Robert. The Great Ascent. New York: Harper, 1963.

Heilbrunn, Otto. Warfare in the Enemy's Rear. New York: Praeger, 1963.

Janowitz. Morris. The Military in the Political Development of New Nations. Chicago: University of Chicago Press, 1964.

Johnson, John J. (ed.). The Role of the Military in Underdeveloped Countries. Princeton: Princeton University Press, 1962.

The Military and Society in Latin America. Stanford: Stanford University Press, 1964.

Jordan, Amos A., Jr. Foreign Aid and the Defense of Southeast Asia. New York: Praeger, 1962.

Kintner, William R., and Kornfeder, Joseph Z. The New Frontier of War. Chicago: Regnery, 1962.

LAgos, Gustavo. International Stratification and Underdeveloped Countries. Chapel Hill: University of North Carolina Press, 1963.

Lieuwen, Edwin. Arms and Politics in Latin America. New York: Praeger, 1960.

Generals vs. Presidents: Neo-militarism in Latin America. New York: Praeger, 1964.

MaAss, Arthur. Muddy Waters: The Army Engineers and the Nation's Rivers. Cambridge: Harvard University Press, 1951. 
Millikan, Max F., and Blackmer, Donald. The Emerging Nations: Their Growth and U. S. Policy. Boston: Little Brown, 1961.

Nehemkis, Peter. Latin America: Myth and Reality. New York: Knopf, 1964.

Osanka, Franklin M. (ed.). Modern Guerrilla Warfare. New York: Free Press, 1962.

Paret, Peter, and Shy, John W. Guerrillas in the 1960's. New York: Praeger, 1962.

Poppino, Rollie. International Communism in Latin America: A History of the Movement, 1917-1963. London: Free Press, 1964.

Porter, Charles O., and Alexander, Robert J. The Struggle for Democracy in Latin America. New York: Macmillan, 1961.

Powers, Patrick W. A Guide to National Defense: The Organization and Operation of the U.S. Military Establishment. New York: Praeger, 1964.

Pustay, John S. Counter-Insurgency Warfare. New York: Free Press, 1965.

Pye, Lucian. Guerrilla Communism in Malaya: Its Political and Social Meaning. Princeton: Princeton University Press, 1956.

Seers, Dudley (ed.). Cuba: The Economic and Social Revolution. Chapel Hill: University of North Carolina Press, 1964.

Stuart, Lyle. The War of the Flea. New York: Doubleday, 1965.

Taylor, Maxwell D. The Uncertain Trumpet. New York: Harper, 1960.

Thayer, Charles W. Guerrilla. New York: Harper, 1963. Mao Tse-Tung. On Guerrilla Warfare. New York: Praeger, 1961.

Valeriano, Colonel Napoleon D., and Bohannan, Charles. Counterguerrilla Operations: The Philippine Experience. New York: Praeger, 1962. 
Villanleva, Victor. El militarismo en el Peru. Lima: Empresa Gráphica T. Scheuch, 1962.

Walterhouse, Harry F. A Time to Build: Military Civic Action-Medium for Economic Development and Social Reform. Columbia: University of South Carolina Press, 1964.

Wythe, George. The United States and Inter-American Relations: A Contemporary Appraisal. Gainesville: University of Florida Press, 1965.

\section{Articles and Essays in Collections}

Heknuis, Dale J., and Youngbloon, John F. "The Nature of the Underdeveloped Areas," International Stability: Military, Economic, and Political Dimensions, ed. Dale J. Heknuis et al. New York: Wiley, 1964.

Lieuwen, Edwin. "The Military: A Force for Continuity or Change?" Explosive Forces in Latin America, ed. Joun J. TePaske and Sydney Nettleton Fisher. Columbus: Ohio State University Press, 1964.

McAlister, Lyle N. "The Military," Continuity and Change in Latin America, ed. John J. Johnson. Stanford: Stanford University Press, 1964.

Rostow, WaLT W. "Guerrilla Warfare in the Underdeveloped Areas," View From the Seventh Floor. New York: Harper, 1964.

Santos, Eduardo. "The Defense of Freedom in Latin America," Responsible Freedom in the Americas, ed. Angel Del Rio. Garden City, N.Y.: Doubleday, 1955.

Tannenbaum, Frank. "Considerations for the Latin American Policy," The Liberal Papers, ed. James Roosevelt. New York: Doubleday, 1962. 


\section{Periodicals}

Adarmes, Mayor José A. Perez. "Acción cívica de las fuerzas armadas," Revista de las fuerzas armadas de Venezuela (Caracas), Nos. 214-17, (Abril-Julio, 1964), pp. $54-61$.

Alba, Victor. "El ejército y la sociedad," Combate (Costa Rica), March-April, 1959.

Alsop, Stewart. "Kennedy's Grand Strategy," Saturday' Evening Post, CCXXXV (March 31, 1962), 11-16.

Auletta, Lieutenant Colonel Anthony J. "Ten-Nation Progress Report,” Army, XIII (July, 1963), 53-59.

Bailey, Jean. "Mapping in Latin America: An Urgent Task for Hemisphere Defense and Economic Development," Army Information Digest, February, 1965, pp. 20-24.

Bellinger, J. "Civic Role in Anti-Guerrilla War," Military Review, September, 1961.

Blanchard, Colonel George S. "Special Warfare Now!" Army Information Digest, XIX (June, 1964), 21-27.

Blanksten, George. "The Aspirations for Economic Development," Annals of the American Academy of Political and Social Science, March, 1961.

Bohannan, Charles T. R. "Anti-Guerrilla Operations," Annals of the American Academy of Political and Social Science, XXXIV (May, 1962), 19-29.

Buell, Raymond Leslie. "The American Occupation of Haiti," Foreign Policy Association Information Service, Vol. V, Nos. 19-20 (November 27-December 12, 1929).

Burke, Mayor RoBert L. "Un tema de interes especial: Acción cívica militar." Military Review, Edición Hispanoamericana, XLIV (Octubre, 1964), 65-75. 
Campos, Lieutenant Colonel Luis Giral. "El programa de acción cívica de las fuerzas armadas," Revista del ejćrcito (Caracas, Venezuela No. 29, (DiciembreEnero, 1963-64).

Clutterbuck, Colonel Richard L. "Military Engineering as a weapon in the Cold War," Military Engineer, LV (July-August, 1963), 229-33.

Cruz, Colonel Santa. "Acción cívica militar," Revista militar (Guatemala), December, 1960.

Decker, W. T. "Anti-Guerrilla Warfare," Marine Corps Gazette, August, 1961.

Dibble, John. "Training in Military Assistance," Army, July, 1956.

Duffy, Colonel John, "Bigger Job for Civic Action," Army, November, 1961.

"Signpost: Success in the Philippines," Army, July, 1963. pp. 60-65.

Easterbrook, Major General Ernest F. "Counterinsurgency Training," Army Information Digest, October. 1962, pp. 12-21.

Enrigue, Gerado Wildt. "La guerra no convencional," Revista militar de Honduras, January-May, 1962.

Evans, David L. "Lessons from Counter-Insurgency Operations," Air University Review, XV (March-April, 1964), 48-54.

Fitzgibbon, Russell, and Johnson, John J. "Measurements of Latin American Political Change," American Political Science Review, September, 1961.

Fletcher, J. E. "Psychology in Civic Action," Infantry, November-December, 1963.

Francis, Michael, J. "Military Aid to Latin America in the United States Congress," Journal of Inter-American Studies, VI (July, 1964), 389-401. 
Furniss, Edgar S., JR. "American Wartime Objectives in Latin Americn," World Politics, II (April, 1950), 373-89.

GaIL, F. L. "Air Missions in Latin America," Air University Review, Fall, 1961.

Gallup, Captain E. L. "Civic Action in Action," Army, XV (September, 1964) 38-42.

Ginsburgh, Colonel Robert W. "Damn the Insurrectos," Military Review, XLIV (January, 1964), 58-71.

HaAr, Lieutenan's Colonel Herbert R., Jr. "Military Civic Action in Peru," Military Engineer, LVII (MayJune, 1965), 166-67.

Hart, Captain, B. H. Liddel. "Guerrilla War: Factors and Reflections," Marine Corps Gazette, XLVI (December, 1962), 22-28.

Helguera, J. Leon. "The Changing Role of the Military in Colombia," Journal of Inter-Annerican Studies, Vol. III, July, 1961.

Horowitz, Irving L. "The Military of Latin America: A Review," Economic Development and Cultural Change, Vol. XIII, January, 1965.

Jablonsky, Major General Harvey J. "Counterinsurgency Is Your Business," Army Information Digest, Vol. XVII, July, 1962.

Johnson, Chalmers A. "Civilian Loyalties and Guerrilla Conflict," World Politics, Vol. XIV, July, 1962.

Jounson, Kenneth F. "Causal Factors in Latin American Political Instability," Western Political Quarterly, XVII (September, 1964), 432-46.

Jolnson, U. Alexis. "Internal Defense and the Foreign Service," Foreign Service Journal, XXXIX (July, 1962), 20-23. 
Kautsky, John. "The Military in Underdeveloped Countries," Economic Development and Cultural Change, XII (July, 1964), 432-47.

Kem, Captain Richard S. "Counter-Insurgency: Clear and Hold Operations in Vietnam," Military Engineer, LVI (July-August, 1964), 241-42.

Lansdale, Edward G. "Viet Nam: Do We Understand Revolution?", Foreign Affairs, XLIII (October, 1964), 75-87.

Army Information Digest, June, 1962, pp. 50-55.

Leacacos, J. P. "Soldier Statesmen," Army, April, 1963.

Lemay, General Curtis. "Air Commando Training," Air Force Information Policy Letter for Commanders, November $1,1963$.

"Civic Action by the Air Force," Vital Speeches, December 15, 1963.

Lieuwen, Edwin. "Neo-militarism in Latin America: The Kennedy Administration's Inadequate Response," InterAmerican Economic Affairs, Vol. XVI (Spring, 1963).

Little, Lieutenant Colonel John T. "Civic Action Campaign for Counter-Insurgency," Army Information Digest, XVII (July, 1962), 52-56.

Maria, Mayor José Garavito. "Comentarios sobre prestaciones sociales militares," Revista de las fuerzas armadas (Bogotá), IX (Marzo y Abril, 1964), 181-85.

Martinez, Enrique Codo. "The Military Problems in Latin America," Military Review, XLIV (August, 1964), 11-19.

McAllister, Lyle. "Civil-Military Relations in Latin America," Journal of Inter-American Studies, III (July, 1961), 341-49.

Methuin, Eugene H. "Ideology and Organization in Counterinsurgency," Orbis, VIII (September, 1964), 106-24. 
Miller, Lieutenant Commander Roger J., and Cochran, Lieutenant Commander James S. "Counterinsurgency in Perspective," Air University Review, XIV (September-October, 1963), 69-72.

Morner, Magnus. "Caudillos y militares en la evolución hispanoamericana," Journal of Inter-American Studies, II (July, 1960), 295-310.

Mulcahy, Colonel James P. "Building Bridges of Understanding," Ammy Information Digest, XIX (January, 1964), 48-56.

Novoa, General Ruiz. "La acción cívica en los movimientos insurrectionales," Revista del circulo militar (Buenos Aires), Marzo, 1964, pp. 78-86.

Nusbaum, Lieutenant Colonel Keith C. "Bandidos," Military Review, July, 1963, pp. 20-25.

O'Meara, General Andrew P. "Opportunities to Our South," Army, November, 1962.

Poneding, Hernando. "Obligatory Military Service: The Social Order and National Defense," Revista de las fuerzas armadas (Colombia), March-April, 1964.

Rene, Captain Carlos Pineda. "Acción cívica militar en Honduras," Revista Militar de Honduras, January-June, 1963.

Rosson, W. "Military Civic Action.” Army, July, 1963.

Rostow, Walt W. "Countering Guerrilla Attack," Army, September, 1961.

Saks, Lieutenant Samuel R. "Operation Amigo," Army, June, 1961, pp. 38-43.

Slover, Colonel Robert H. "This Is Military Civic Action," Army, Vol. XII (July, 1963).

- "Action through Civic Action," Army Information Digest, XXVII (October, 1962), 7-11. 
Smith, Robert F. "The United States and Latin American Revolutions," Journal of Inter-American Studies, IV (January, 1962), 89-105.

_- "Stability Equals T.R. Corrolary," American Journal of International Law, January, 1962.

Vallance, Theodore R. "Light on the Twilight War," Army Information Digest, January, 1963, pp. 36-42.

Von Der Mehden, Fred R., and Anderson, Charles. "Political Action by the Military in the Developing Areas," Social Research, Winter, 1961.

Waggener, Lieutenant Colonel John C. "Army Civic Action in Southeastern Peru," Peruvian Times, March 5, 1965, p. 3, and April 2, 1965, p. 3.

Walterhouse, Harry F. "Civic Action," Military Review, August, 1962.

- "Good Neighbors in Uniform," Military Review, XXXV (February, 1965), 10-18.

"Civic Action: A Counter and Cure for Insurgency," Military Review, XLII (August, 1962), 47-54.

Whiteman, L. E. "The Stake at Panama," Army-Navy-Air Force Journal and Report, January 18, 1964.

' Our Role in Latin America,' Reporter, November 23, 1962, pp. 30-33.

Windle, Charles, and Valtance, T. R. "Optimizing Military Assistance Training," World Politics, October, 1962, pp. 91-107.

Wolf, Charles. 'Defense in Underdeveloped Countries,' Operation Research, November-December, 1962.

Wyckoff, Theodore. "The Role of the Military in Latin America," Western Political Quarterly, XIII (September, 1960), 745-63.

Zook, Captain D. H. "United States Military Assistance to Latin America," Air University Review, September-October, 1963. 


\section{Publications of Private and Other Organizations}

Coward, H. Roberts. Military Technology in Developing Countrics. Cambridge: Center for International Studies, Massachusetts Institute of Technology. April 15, 1960.

Davison, W. P. Political Side-Effects of the Military Assistance Program. RAND Corp., 1960.

Glick, Edward 13. The Feasibility of Arms Control and Disarmantent in Latin America. Rept. No. CP-1274. Santa Monica, Calif.: Systems Development Corporation, August 9, 1963.

Hausrath, Alfred H. Cizil Affairs in the Cold War. Staff Paper OEO-SP-151, Johns Hopkins University, operating under contract with the Department of the Army, l'ebruary, 1961.

McArdle, Catherine. The Role of Military Assistance in the Problem of Arms Control: The Middle East, Latin America, and Africa. Cambridge: Center for International Studies, Massachusetts Institute of Technology, September 11, 1963.

Menges, Constantine. Arms Control and Disarmament in Latin America. Columbia University: Institute of War and Peace Studies, May, 1964.

Pauker, Guy J. Notes on Non-Military Measures in Control of Insurgency. RAND Corp., 1962.

UNGER, JESS P. The Military Role in Nation Building and Economic Development. Comparative Administrative Group, American Society for Public Administration, International Development Research Center, Indiana University, 1963. mimeo.

Union Panamericana, America en cifras, 1961 and 1963. Instituto Interamericano de Estadistica, Secretaría General de la Organización de los Estados Americanos, Wash- 
ington, D.C. These statistical presentations of various aspects of Latin American life cover such subjects as education, agriculture. demography, balance of payments, national production, and housing.

Wolf, Charles, Jr. Somc Connections between Economic and Military Assistance Programs in Underdeveloped -Ircas. Study P-2389, RAND Corp., August 1, 1961.

. The Political Effects of Military Programs: Some Indications from Latin America. Memorandum No. RM3676-ISA, prepared for the Office of the Assistant Secretary of Defense-International Security Affairs, by the RANI) Corp., June, 1963.

\section{U.S. Government Publications}

Church, Senator Frank. "Military Assistance to Latin America," Congressional Record, March 28, 1960, p. 6224.

1)ecker, General George H. "Special Warfare: A Progress Report," in Special Warfare, U.S. Army-An Army Spccialty. Office of Information, Department of the Army, undated.

Gellner, Charles R. U.S. Military Aid Programs in Latin America. Foreign Affairs Division, Library of Congress, 1960.

Hilsman, Roger. "Internal War: The New Communist Tactic," Remarks at Institute of World Affairs (San Diego). August 10, 1961, in Department of State Press Release No. 561, August 9, 1961.

Inter-American Geodetic Survey. Mission Organization Activities. October 1, 1963, mimeo.

J.eighton, Richard, and SAnders, Raliil (eds.). Insilgency and Counterinsurgency: An Anthology, Publication No. R-226, Industrial College of the Armed Forces, School of Resident Studies, Washington, D.C., October, 1952. 
New Dimensions in the Cold War: Transition and Tensions in the Underdeveloped World. Industrial College of the Armed Forces, Washington, D.C., 1963.

Long, IVIlliam I:. The Employment of Civic Action Prograns by the Military Assistance and Advisory Group. Doc. M-35582-7-NC, L849C, Maxwell Air Force Base, Ala., April, 1963.

Martin, Edwin. "Steps We Are Taking to Combat Communist Subversion," Remarks before House Committee on Foreign Affairs, February 18, 1963, in Department of State Bulletin, March 1, 1963, p. 347.

Rostow, Walt W. "Countering Guerrilla Attack," Department of State Bulletin, August 7, 1961.

. 'The Alliance for Progress: August 1964,' Department of State Press Release No. 359, August 6, 1964.

Schmitt, Karl M. The Role of the Military in Contemporary Mexico. Paper No. 4110, External Research Staff, Department of State.

U.S. Air Force. Fact Sheet, "Special Air Warfare." Office of Information, Washington, D.C., March, 1965.

- Information and Guidance on Military Assistance. Prepared by the Evaluation Division, Assistant for $\mathrm{Mu}$ tual Security, Deputy Chief of Staff; 5th ed., January, 1960.

. School for Latin America, Information Booklet. Albrook Air Force Base, Canal Zone, April, 1963.

. Military Assistance Bilaterals. Published by the Evaluation Division, Assistant for Mutual Security, Deputy Chief of Staff, Materiel, undated. Texts of bilateral treaties under Mutual Security Act.

- School for Latin America, Prospectus. Albrook Air Force Base, Canal Zone, September 15, 1964.

. Southern Command Operational Control. The Air Commandos in Panama. Albrook Air Force Base, Canal Zone, undated, mimeo. 
U.S. Air University. Collected Readings on Counterinsurgency. Air Command and Staff College Correspondence Course 3a, Supplementary Text, Extension Course Institute (Gunter Air Force Base. Ala.), May, 1963.

- Warfarc Systems School Catalogue. Maxwell Air Force Base, Ala.. September, 1962.

U.S. Army, Civil Affairs School. Special Te.rt, Command and Staff Guidelines for Cizic Action. Doc. No. ST-41-10-90, Ft. Gordon, Ga., undated.

- Program of Instruction for Cizic Action. Doc. No. 41-I-F7, Ft. Gordon, Ga., September 4, 1964.

- The Concept of Civic Action. Lesson Plan 5135, Ft. Gordon, Ga., April, 1964.

U.S. Army, Continental Army Command. Counterinsurgency Operations. Pamphlet No. 516-3, Ft. Monroe, Va., October 20, 1964.

U.S. Army. Operations against Irregular Forces, Field Manual 31-15, 1961: Counterinsurgency Operations, Field Manual 31-16, Felıruary, 1963: Guerrilla Warfare and Spccial Opcrations. Field Manual 31-21. September, 1961: United States Counterinsurgency Forces. Field Manual 31-22, 1963: Cizil Affairs Operations, Field Manual 41-10, May, 1962 ; and Doctrinal Guidancc, Field Manual 100-1. September, 1959.

C.S. Army, Sichool of the Americas. Cataloguc. U.S. Armed Forces, Southern Command, Ft. Amador, Canal Zone. January 1, 1964.

. History and Current Opcrations. Fit. Gulick, Canal Zone, undated, mimeographed.

U.S. Army, Special Warfare Center. Spccial Warfare. Ft. Bragg, N.C., undated, mimeographed.

Historical Report. 1963. Ft. Bragg, N.C., January 31, 1964.

. Précis of Courses. Ft. Bragg, N.C., July, 1964. 
U.S. Congress. Senate and House, Hearings on Foreign Assistance and Foreign Assistance Appropriations Acts, 1959-65.

Senate and House, Hearings on Foreign Operations and Foreign Operations Appropriations Acts, 1964-65.

. Senate and House, Hearings on Mutual Security and Mutual Security Appropriations Acts. 1959-65.

. Summary Presentation, Proposed Mutual Defense and Development Programs, FY 1965. Presented by the Agency for International Development and the Department of Defense, April, 1964.

. "Statistics on Military Aid to Latin America," Congressional Record, August 2, 1962, pp. 14409-40.

U.S. Department of the Army. Military Civic Action. Pamphlet No. 360-207, Washington, D.C., May, 1964.

Military Civic Action. Civic Action Branch, Civil Affairs Directorate, Office of the Deputy Chief of Staff for Military Operations, undated.

U.S. Department of Defense. Military Assistance Facts. Washington, D.C., May, 1963.

Program of Instruction. Washington, D.C. : Military Assistance Institute, January, 1965.

U.S. Embassy at Bogotá, Escuela de Ingenieros Militares, October 4, 1964.

U.S. House of Representatives, Committee on Foreign Affairs. Regional and Other Documents Concerning U.S. Relations with Latin America. 87th Cong., 2d Sess. (January 15, 1962).

- Staff Memorandum, Background Material on the Mutual Security Program: Fiscal Year 1961. 86th Cong., 2d Sess. (March 8, 1960).

U.S. House of Representatives. Report, Special Study Mission to Latin America: Venezuela, Brazil, Argentina, Chile, Bolivia, Panama, by Representatives Armistead I. 
Selden, Jr., and Dante B. Fascell. H. Rept. No. 70 , 87th Cong., 1st Sess. (March 9, 1961).

- United States Defense Policies in 1963. Study prepared for Representative Melvin Price by the Library of Congress, Legislative Reference Service. H. Doc. No. 335, 88th Cong., 2d Sess. (May 4, 1964).

. Subcommittee on Inter-American Affairs of the Committee on Foreign Affairs. Hearings, Castro-Communist Subversion in the Western Hemisphere. 88th Cong., 1st Sess., February 18, 20, 21, 26, 27, and 28, March 4, 5, and 6, 1963.

. Hearings, Communism in Latin America. 89th Cong., 1st Sess. (February 16 and 25), March 2, 10, 16, and $30,1965)$.

. Report, Communism in Latin America. 89th Cong., 1st Sess. (April 14, 1965).

. Report on United States Relations with Latin America. H. Rept. No. 354, 86th Cong., 1st Sess. (May 12, 1959).

U.S. House of Representatives, Subcommittee on International Organizations and Movements, of the Committee on Foreign Affairs. Hearings, Winning the Cold War: The U.S. Ideological Offensive. 88th Cong., 2d Sess. (January 1516, 1964), Part 8.

U.S. House of Representatives, Subcommittee on National Security Staffing and Operations. The Ambassador and the Problem of Co-ordination. House Doc. No. 36, 88th Cong. 1st Sess. (September 13, 1963).

U.S. Joint Chiefs of Staff. Dictionary of U.S. Military Terms for Joint Usage. JCS Publication No. 1, February 1, 1964.

U.S. Marine Corps. Operations against Guerrilla Forces. Field Manual FMFM 21. Washington, D.C. ; Department of the Navy, August 14, 1962. 
U.S. Naval Institute. Studies in Guerrilla Warfare. Annapolis, Md., 1963.

U.S. Navy, Report on Latin American Conference. Chief of Civil Engineers, Bureau of Yards and Docks, September 10-11, 1962, mimeo.

-__. Seabee Technical Assistance Teams: An Existing Counterinsurgency Force, undated, mimeo.

U.S. President, Committee to Study the United States Military Assistance Program. Conclusions Concerning the Mutual Security Program. Washington, D.C., 1959.

U.S. Senate, Committee on Foreign Relations. Foreign Assistance Act of 1965. Rept. No. 170 on S 1837, 89th Cong., 1st Sess. (April 28, 1965).

- Study Mission in the Caribbean Area, December, 1957. Report of Senator George D. Aiken, 85th Cong., 2d Sess. (January 20, 1965).

U.S. Senate, Subcommittee on American Republics Affairs of the Committee on Foreign Relations. Study, United States-Latin American Relations. Sen. Doc. No. 125, 86th Cong., 2d Sess. (August 31, 1960).

U.S. Senate, Subcommittee on Disarmament, of the Committee on Foreign Relations. Control and Reduction of Armaments: Disarmament and Security in Latin America. Staff Study No. 7, 85th Cong., 1st Sess. (May 12, 1957).

U.S. Senate, Subcommittee on National Security and International Operations of the Committee on Government Operations. Memorandum of National Security Policy. 89th Cong., 1st Sess. (April 26, 1965).

\section{Unpublished Materials}

Anthony, Henry. "The Political Behavior of the Military in Latin America." Ph.D. thesis, Northwestern University, August, 1964. 
Ashley, Commander Donn L. "Dungaree Diplomacy: Seabee Civic Action Projects as an Instrument of United States Cold War Policy." Research paper, U.S. Naval War College, March, 1964.

Ashton, Colonel T. M., USAF. "Civic Action." Paper presented to the Inter-American Defense College, January 29, 1963.

"Counter-Guerrilla Operations in the Philippines, 1946-1953."

A seminar report on the Huk Campaign, Ft. Bragg, N.C., June 15, 1961, mimeo.

Ekern, Halvor O. "Military Civic Action as an Instrument of Foreign Aid." Sixth Senior Seminar in Foreign Policy, Foreign Service Institute, Department of State, June 15, 1964, mimeo.

Final reports of the First, Second, Third, and Fourth conferences of the Armies of America, Canal Zone, 1960-64.

Futrell, Robert F. "Background and Growth of Military Civic Actions : Recent Military Civic Action in the United States Air Force." Lecture 2, Aerospace Studies Institute, Air University, Maxwell Air Force Base, Ala., June, 1964.

Hammer, Colonel James E. (Inter-American Geodetic Survey). "Mapping Operations in Central and South America." Paper presented to the American Congress on Surveying and Mapping, March 27, 1963.

Landsdale, Colonel Edward G. "Memorandum on Civic Activities of the Military, Southeast Asia." Prepared by the President's Committee to Study the United States Military Assistance Program, March 13, 1959.

Read, Gerald. "Civic-Military Rural Education of Cuba: Eleven Eventful Years (1936-1946)." Ph.D. dissertation, Ohio State University, 1950. 


\section{Bibliographies}

A Preliminary Bibliography on Studies of the Roles of Military Establishments in Dctcloping Nations. Washington, D.C. : Special Operations Research Office, American University, July, 1963.

Documents Arailable from the E.tternal Research StaffLatin America. Prepared for the Foreign Area Research Co-ordination Group by the External Research Staff, Bureau of Intelligence and Research, Department of State, June, 1964.

Human Factors in Civic Action: A Selected, Annotated Bibliography. Language and Area Training Division, Human Resources Resenrch Office, George Washington University, under contract to the Department of the Army, June, 1963.

Latin America: Hemisphere Partner, A Bibliographic Survey. Pamphlet 550-1, Headquarters, Department of the Army, June, 1964.

Political Dezelopment-A Bibliography, 1960-196t. External Research Paper 159, External Research Staff, Department of State, Washington, D.C., August, 1964.

Selected Bibliography on Counterinsurgency'. Norfolk, Va.: Armed Forces Staff College, August 21, 1964, mimeo.

Studics in Progress. Amcrican Republics. Bureau of Intelligence and Research, Department of State, 1964.

Survey of Investigations in Progress in the Field of Latin American Studics, compiled by Philip F. Flemion and Murdo J. Macleod, School of Inter-American Studies, University of Florida, Gainesville, Fla. Washington, D.C. : Pan-American Union, October, 1962. 

Index 



\section{Index}

Agency for International Development, 7, 104-6, 108, 109

Aiken, George D., 66, 69

Air Commando Operations, 166 68

Air Force, U.S.: Office of Scientific Research, 168, 169; training, 161-65; Tropical Survival School, 147

Alba, Victor, 74

Alexander, Robert, 27

Alliance for Progress, 10, 19, 72, 73, 105 ; charter, 3

Alliance for Progress Security, 238, 240

Alsop, Stewart, 81

Argentina, Republic of, 22, 185, $219,223,231$; administration of military civic action, 124, 125;

AID and MAP civic action, 239; changes of head of state, 249 ; draftees, 186; exchange of notes with U.S., providing for military equipment, 291-96; failure of civilian government, 23 ; graduates of School of the
Americas, 145; military civic action, 62,63 ; military expenditures and force levels, 226; military take-overs, 38 ; proposed U.S. military assistance, 238; students in Army Special Warfare School, 149; U.S. military arrangements with, 34 ; U.S. military assistance to, 36

Armed Forces Assistance to Korea Program, 75

Armed forces literacy education (Colombia), 193-94

Army, U.S.: organizations for counterinsurgency and civic action, 151; Special Warfare Center and School, 148-51, 275, 276

Army Civil Affairs School, 15255

Batista, Fulgencio, 40

Bay of Pigs, 95 
Betancourt, Romulo, 25, 201

Bogotá, Act of (1960), 3, 19

Bolivia, 8, 22, 25, 43, 65, 219, 220 ; administration of military civic action, 121-24; AID and MAP civic action, 239 ; changes of head of state, 249-51; draftees, 186; graduates of School of the Americas, 145; military expenditures and force levels, 226; military take-over, 38 ; 1964 coup, 69; proposed U.S. military assistance, 238; students in Army Special Warfare School, 149 ; U.S. military arrangements with, 34 ; U.S. military assistance to, 36

Bowles, Chester, 72

Brazil, 8, 22, 43, 194, 195, 219; AID and MAP civic action, 239; army engineers, 62; changes of head of state, 251, 252 ; deficiencies of civilian government, 23, 24; draftees, 186; graduates of School of the Americas, 145; Joint U.S. Military and Defense Commission, 285 -87; military expenditures and force levels, 227 ; military take-over, 38; proposed U.S. military assistance, 238 ; students in Army Special Warfare School, 149; U.S. military arrangements with, 34 ; U.S. military assistance to, 36

Briceno, Gonzalo, 219

Bundy, McGeorge, 97

Bureau of Inter-American Affairs, 105

Burke, Arleigh, 95

Busch, German, 42

Calhoun, John C., 55

Caudillos, 40

Castro, Fidel, 14, 18, 25

Central America: unusual aspects of military civic action in, 13134
Central American Conferences on Civic Action, 134

Chasmas, 25

Chief of Civil Engineers Latin America Conference, 79

Chile, 8, 25, 43, 185; AID and $M A P^{\prime}$ civic action, 239; army engineers, 62 ; changes of head of state, 252; draftees, 186; graduates of School of the Americas, 145; measures for administration and implementation of military civic action, 119-20; military expenditures and force levels, 226; proposed U.S. military assistance, 238 ; students in Army Special Warfare School, 149; U.S. military arrangements with, 34; U.S military assistance to, 36

Church, Frank, 67

Civic action, military: see Military civic action

Civilian government, crises in Latin America, 22-24

Clark, Bruce, 57, 75

Colombia, 22, 185; AID and $M \Lambda P$ civic action, 239 ; armed forces and constitutional government, 38, 39; changes of head of state, 253 ; civilian government, 24; draftees, 186; graduates of School of the Americas, 145; military civic action, 192-94 ; military expenditures and force levels, 227; National Committee on Military Civic Action, 119; proposed U.S. military assistance. 238 ; students in Army Special Warfare School, 149; U.S. military arrangements with, 34 : U.S. military assistance to, 36

Communism: Case History of Communist Penctration: Guatemala, 32: effect of poverty on influence of, 19, 20; international, Report of Special Committee on Security against Subversive Action, 273-74; penetration of Western Hemisphere, 14 
Cook, Truman F., 123

Costa Rica, 15, 19, 22, 132, 185 , 223; AID and MAP civic action, 239; changes of head of state, 253; draftees, 186 ; graduates of School of the Americas, 145 ; military expenditures and force levels, 227; proposed U.S. military assistance, 238; students in Army Special Warfare School, 149; U.S. military arrangements with, 34 ; U.S. military assistance to, 36

Counterinsurgency, 37; administrative and planning agencies, 91-137; Country Team process, 98,99 ; definition, $5,7,8$; difficulties in training for, 172-77; military civic action and, 53, 179-211; précis of Fort Bragg Special Warfare School, 275, 276; training for operations, 141-77; U.S. Army organizations for, 151

Counterinsurgency Operations Course, 150

Counter-Insurgency Planning Guide, 184

Cuba, 8, 31, 33, 43; attempted invasions of, 14 ; changes of head of state, 253, 254; Communist influence, 14 ; graduates of School of the Americas, 145; lack of leadership skill, 20 ; nationalist revolution, 14; U.S. military assistance to, 36

Defense Language Institute, 17374

Defense, U.S. Department of: International Security Affairs Office, 92 ; organizations for counterinsurgency civic action, 115

Democratic party, 1964 platform, 72

Diaz, Porfirio, 40
Dick, W. W., Jr., 109

Dictators, military, U.S. support of, 16,17

Dictionary of United States Military Terms for Joint Usage. 5

Dillon, C. Douglas, 18

Dominican incident (1965), 209 11

Dominican Republic, 22, 219; AID and MAP civic action, 239; changes of head of state, 254, 255 ; draftees, 186 ; Guardia Nacional, 60 ; graduates of School of the Americas, 145: military expenditures and force levels, 226 ; military take-over, 38; occupation by U.S. Marines, 58; resolutions adopted by the 10th Meeting of Consultation of the American Ministers of Foreign Affairs, 299-305; U.S. military arrangements with, 34 ; U.S. military assistance to, 36

Draper Committee, 66, 71

Drustrup, N. J., 78, 79

Dulles, Allen, 95

Duncan, George T., 148

Dungan, Ralph Anthony, 109

Ecuador, 22, 185, 219; AID and MAP civic action, 239; changes of head of state, 255, 256; Civic Action Military Training Team, 83; civilian government, 25 ; draftees, 186 ; graduates of School of the Americas, 145; military expenditures and force levels, 227 ; military take-over, 38 ; proposed U.S. military assistance, 238 ; students in Army Special Warfare School, 149; U.S. military arrangements with, 34 ; U.S. military assistance agreements with, 277-84; U.S. military assistance to, 36 Eisenhower, Dwight David, 75. 153: Newport Declaration (1960), 18 
El Salvador, 8, 22; administration of military civic action, 120, 121; AID and MAP civic action, 239; changes of head of state, 256; draftees, 186; graduates of School of the Americas, 145 ; military expenditures and force levels, 227; proposed U.S. military assistance, 238; students in Army Special Warfare School, 149; U.S. military arrangements with, 34; U.S. military assistance to, 36

Enemark, William, 70

Engineers, U.S. Corps of, 65, 73

Food for Peace, 10, 93, 136

Foreign Assistance Act (1961), $225 ; 1965$ amendment, 76

Frondisi, Arturo, 23

Fuerzas Armadas de Cooperación, 188

Fulbright, J. William, 66, 69, 211

Gates, Thomas S., 108

General Survey Acts (1824), 55

Gilpatrick, Roswell, 97

Gómez, Laureano, 40, 62

Good Neighbor Policy, 10

Gorgas, William, 55

Goulart, Julião, 24

G/PM, 103-6

Gruening, Ernst, 45

Guatemala, 22, 31, 43, 132, 196, 223 ; administration of military civic action, 127-31; AID and MAP civic action. 239; Case History of Communist Pcnetration, 32 ; changes of head of state, 257, 258: Civic Action Military Training Team, 83; Communist influence, 14 ; draftees, 186; exchange of notes with U.S. on furnishing articles and services to strengthen internal-security capabilities, 287 89; graduates of School of the Americas, 145 ; military expenditures and force levels, 227 ; military take-over, 38 ; proposed U.S. military assistance, 238 ; students in Army Special Warfare School, 149; U.S. military arrangements with, 34 ; U.S. military assistance to, 36 Guevara, Ernesto "Che," 33, 180

Haiti, 8; AID and MAP civic action, 239; changes of head of state, 257, 258; draftees, 186; Gendarmerie, 59, 60; graduates of School of the Americas, 145; military expenditures and force levels, 226; occupation by U.S. Marines, 58; students in Army Special Warfare School, 149; U.S. military arrangements with, 34 ; U.S. military assistance to, 36

Hamilton, Fowler, 97

Hannah, John A., 75

Harriman, W. Averell, 97

Havana meeting of Latin American Communists (1954), 35

Heads of State: illegal and unscheduled changes, 249-65

Hemispheric-security doctrine. 53-85

Herter, Christian, 108

Honduras, 22, 132, 220, 221, 223; administration of civic military action, 126, 127; AID and MAP civic action, 239; changes of head of state, 259 ; draftees. 186 ; graduates of School of the Americas, 145 ; military expenditures and force levels, 226; military take-over, 38; students in Army Special Warfare School, 149; U.S. military arrangements with, 34 ; U.S. military assistance to, 36 
House of Representatives, U.S.: Committee on Foreign A ffairs 99, 100; Subcommittee on InterAmerican Affairs, 35

Humphrey, Hubert H., 33, 66

Industrial College of the Armed Forces, 173

Infrastructure, definition, 223

Institute of Inter-American Affairs, 10, 65

Insurgency : conditions giving rise to, 53; definition, 7; factors producing conditions, 41

Inter-American Committee for the Alliance for Progress, 93

Inter-American Conference (10th, Caracas, 1954), 15

Inter-American Defense Board, 63; Resolution XLVII, 82, 128, 271-74

Inter-American Defense College, 170-72

Inter-American Defense Force, 210

Inter-American Development Bank, 19

Inter-American Economic and Social Council, 105

Inter-American Geodetic Survey, 155-57

Inter-American Institute for Agricultural Science, 156

Inter-American Military Co-operation, 268-70

Inter-American Police Academy, 98

Inter-American Treaty of Reciprocal Assistance (1947), 14, 29, 64

Interdepartmental Seminar, 99

Internal Defense Plans, 98, 11112

International Coffee Agreement (1961), 21

International Co-operation Administration, 63,64
International Police Academy, 170

Intervention, U.S. in Latin America : goals, 61

Jamaica: AID and MAP civic action, 239

Johnson, Alexis, 97

Johnson, John J.: Military and Society in Latin America, The. 27

Johnson, Lyndon B., 24, 243

Katzenbach, Nicholas, 97

Kearny, Stephen W, 55

Kennedy, John F. 19, 31, 32, 67, $72,73,79,94,97,141,172$

Kennedy, Robert F., 82, 95, 97, 141

Khrushchev, Nikita, 32, 35, 68, 180

Korea: effect of war on U.S.Latin American interests, 17, 18; surplus construction materiais for, 75 ; see also South Korea

Krickenberger, C. F., Jr., 77

"Latin American": difficulties in use of term, 8

Latin American Medical Conference, 163

LeMay, Curtis E., 35, 161, 162

Lemnitzer, L. L., 69, 97

Lend-Lease Act, 63

Lipscomb, Glenard P., 110

López, Lindley, 219

López Allenaro, Oswaldo, 127 
McCone, Alan, 97

McNamara, Robert Strange, 44, $70,84,163,218,240,243$

Malaya, 68

Marine Corps, U.S. : Latin American occupations, 58; training of local military forces, 59

Marshall Plan, 17

Martin, Edwin, 33, 44, 100, 150

Matthews, Herbert, 61

Medical dispensaries, 193

Metcalf, Clyde H.: History of the United States Marine Corps, 59

Mexico, 15, 43, 185, 223; administration of military civic action, 125, 126; AID and MAP civic action, 239; changes of head of state, 259; draftees, 186; graduates of School of the Americas, 145 ; military expenditures and force levels, 227 ; students in Army Special Warfare School, 149; U.S. military arrangements with, 34; U.S. military assistance to, 36

Military assistance, 217, 218; difficulties of co-ordination, 112-17; field administration, 107; U.S. aid to Latin America (1952-61), 237; use of U.S.furnished armaments for internal defense, 111, 277-95

Military Assistance Advisory groups, 112, 113

Military Assistance Institute, 144

Military Assistance Programs, 109 ; control by United States, 44-48

Military civic action: administration in Latin America, 117-31; Civic Action Military Training Team, 83, 84; and counterinsurgency, 179-211; definition, 6 ; effects, 197-205; foundation for, 63-66; future of, 236-44 ; opposition to, 80-83; as part of counterinsurgency doctrine, 5385 ; in perspective, $222-35$; "problem area," 296-98; problems confronting, 235 ; professional and competitive interests in, 77-80 ; projects, 183-96; toplevel direction and team work, 134 ; U.S. Army organizations for, 151 ; U.S. precedents for, 54 ; unusual aspects in Central America, 131-34

Military dictators: see Dictators, military

Military equipment, Latin American requests for, 222

Military forces : civic actions, 5385 ; as insurgents, $37-48$; as reformers, 42,43

Military governments: conditions imposed for return to civilian control, 39,40

Military personnel : effect of U.S., on local military, 219, 220

Miller, Edward, 30

Mobile Training Teams, 116, 157

Morse, Wayne, 66

Munro, Dana, 60

Murrow, Edward R., 97

Mutual Security Act (1951), 30, 64

Mutual Security Act (1959), 45, 71,75

Mutual Security Administration, 68

National Security Action Memorandum No. 119, 154

Navy, U.S.. Bureau of Yards and Docks, 78; Civil Engineers Corps, 78, 79; SEABEE Technical Assistance teams, 160, 161

Newport Declaration (1960), 18

Nicaragua, 41, 132, 223; AID and MAP civic action, 239 ; changes of head of state, 260; draftees, 186; graduates of School of the Americas, 145 ; military expenditures and force levels, 227; occupation by U.S. Marines, 58; students in Army Special Warfare School, 149; U.S. military arrangements with, 34 : U.S. military assistance to, 36 
Office of Regional Political Affairs, 105

O'Meara, Andrew, 105, 106

Operations Co-ordination Board, 94,100

Organization of American States (OAS), 16

\section{P'áez, Federico, 40}

Panama, 8; AID and MAP civic action, 239; changes of head of state, 260, 261; draftees, 186; graduates of School of the Americas, 145 ; military expenditures and force levels, 227 ; proposed U.S. military assistance, 238; U.S. military arrangements with, 34 ; U.S. military assistance to, 36

Paraguay, 41, 65, 83, 185; AID and MAP civic action, 239; changes of head of state, 261, 262; draftees, 186; exchange of notes with U.S. regarding road construction, 289-91; graduates of School of the Americas, 145 ; military control of national government, 62 ; military expenditures and force levels, 226; proposed U.S. military assistance, 238 ; U.S. military arrangements with, 34 ; U.S. military assistance to, 36

Peace Corps, 10

Peralta, Enrique, 130

Perón, Juan, 22, 42

Peronismo, 23

Peronistas, 185

Peru, 185, 230; AID and MAP civic action, 239; changes of head of state, 262; draftees, 186 ; fall of dictator, 22 ; graduates of School of the Americas, 145 ; military expenditures and force levels, 227; Popular Co-operation Movement, 10 ; proposed U.S. military assistance, 238; students in Army Special Warfare School, 149;
U.S. military arrangements with, 34 ; U.S. military assistance agreement, 277,278 ; U.S. military assistance to, 36 ; vocational training for recruits, 190, 191

Philippines, 68; insurrection, 57

Popular Co-operation Movement, 10

Poverty : effect on Communist influence, 19 ; and political instability, 20

Prebisch, Raul, 21

President's Committee to Study United Military Assistance Program: see Draper Committee

Preventive medicine civic-action team, 164

Punta del Este Conference (1962), 15

Pye, Lucien, 20

Quadros, Janio, 24

Reed, Walter, 55

Rio Treaty: see Inter-American Treaty of Reciprocal Assistance Road-construction programs, 185 , $189,190,193$

Rowan, H. W., 101

Rusk, Dean, 74, 84, 172, 243

Sanjines Goitia, Julio, 123

San José, Costa Rica, American foreign ministers meeting (1960), 15, 19

Santos, Eduardo, 67

School of the Americas, 144-48, 150 
School construction, 189

Secretary of Defense, U.S. : composition and organization of office, $102-6$

Senate, U.S., Committee on Foreign Relations, 75

Shingler, Don, 71

Smathers, George A., 67

Social technology, 20

South Korea : conflict, 57-58; invasion (1950), 68

South Vietnam, 77, 78; military civic action, 58

Southeast Asia, counterguerrilla operations, 66

Special Air Warfare Center, 143, 165-66

Special Group for counterinsurgency, 95-111; composition and organization, 96

Special Operations Research Office, 109

State Department, U.S.: "National Interdepartmental Seminar on Problems of Development and Internal Defense," 142,143

Subversion, definition, 7

Szulc, Tad: Truilight of the Tyrants, 22

Taylor, Maxwell D., 57, 74, 75, $77,81,95,141,153$

Tolima highway (Colombia), 193

Toro, José David, 42

Trujillo Molina, Rafael L., 41

Ubico, Jorge, 40

Unger, Jess, 176

United Nations, 75

United States: bilateral military arrangements, 34 ; bilateral military assistance, 64 ; economic assistance policies, 19; Latin
American policy, 28; military assistance program, 29; military assistance program for Latin America, 29, 33, 35, 36; National Objectives regarding Overseas Internal Defense, 7 , 266-67; Points in Explanation of U.S. Military Assistance Program for Latin America, 33

Uruguay, 185, 223; AID and MAP civic action, 239; changes of head of state, 262 ; draftees, 186 ; graduates of School of the Americas, 145 ; military expenditures and force levels, 226; proposed U.S. military assistance, 238; U.S. military arrangements with, 34 ; U.S. military assistance to, 36

Velasco Ibarra, José Maria, 25

Venezuela, 15, 22, 25, 43, 62, 83, 185,223 ; administration of military civic action, 120; AID and MAP civic action, 239; armed forces and constitutional government, 38 , 39; changes of head of state, 263; draftees, 186; graduates of School of the Americas, 145 ; military expenditures and force levels, 227; proposed U.S. military assistance, 238; students in Army Special Warfare School, 149; U.S. military arrangements with, 34 ; U.S. military assistance to, 36

Villeda Morales, Ramón, 220

Water supplies, 193

Wood, Robert J., 35

Ydigoras Fuentes, Migel, 127, 129 




Burdened by seemingly insurmountable difficulties and marked by frequent failures, the Latin American experiment in civic action takes on tremendous im portance when considered in the light of recent developments in other parts of the world threatened by Communist subversion. These developments indi cate a tendency on the part of the present admunistra tion in Washington to abandon the principle by which civic action becomes the means of overcoming in. surgency directed from without. Instead, as in Viet nam, there has been a resort to military force as a means of answering Communist subversion

The success of the Latin American experiment may, in the long run, very well be of equal or even more significance than recent events in Southeast Asia. For we are attempting, in the Western Hemisphere. to discover whether a politically influential force can become the means for national self help in eradicat ing social unrest before it becomes externally im planted and directed insurgency. If the experiment should fail, the United States may well contront a dilemma equal to that posed by Vietnam that is dis turbingly closer to home.

Willard F. Barber has had a distinguished career in the U.S. Foreign Service in Washington, Latin America and behind the Iron Curtain, as well as shorter duty in Burma, Iran. Pakistan, and Turkey He is now Lecturer in International Affairs at the University of Maryland. C. Neale Ronning is currently visiting as sociate professor of Latin American affairs at the School for Advanced Studies of the Johns Hopkins University, and has taught at a number of American universities. During 1964 65, both Mr. Ronning and Mr. Barber held visiting professorships under the Mershon Social Science Program of the Ohio State University 
OTHER PUBLICATIONS OF THE SOCIAL SCIENCE PROGRAM OF THE MERSHON CENTER ...

Books

THE WESTERN ALLIANCE: ITS STATUS AND PROSPECTS, edited by Edgar S. Furniss, Jr.

$\$ 4.75$

THE UNCOMMON DEFENSE AND CONGRESS, 1945-1963, by Edward A. Kolodziej. $\$ 7.50$

THE FRENCH ARMY IN POLITICS, 1945-1962, by John Steward Ambler.

$\$ 6.50$

THE POLITICS OF BRITISH DEFENSE POLICY, 1945-1962, by William P. Snyder

$\$ 6.25$

Pamphlets

A Revaluation of Collective Security: The OAS in Action, by Jerome Slater.

Ocean Sciences, Technology, and the Future International Law of the Sea, by William T. Burke.

$\$ 1.50$

The Dilemma of British Defense: The Imbalance between Commitments and Resources, by Walter Goldstein.

The United States and the Threat to Security in Latin America, by Edwin Lieuwen.

FROM YOUR BOOKSTORE OR...

\section{OHIO STATE UNIVERSITY PRESS}

164 WEST NINETEENTH AVENUE

COLUMBUS, OHIO 43210 